\title{
AT HOME WITH NEW ZEALAND IN THE 1960S
}

\section{Richard Thomson}

\author{
A thesis \\ submitted to Victoria University of Wellington \\ in fulfilment of the requirements for the degree of \\ Master of Arts \\ in History
}

Victoria University of Wellington

2014 

London was but a foretaste of this nomadic civilization which is altering human nature so profoundly, and throws upon personal relationships a stress greater than they have ever borne before. Under cosmopolitanism, if it comes, we shall receive no help from the earth. Trees and meadows and mountains will only be a spectacle, and the binding force that they once exercised on character must be entrusted to Love alone.

-EM Forster, Howard's End (London: Everyman's Library, 1992), 272-3.

The journey was one that would now no doubt be made by motorcar, with a view to making it more agreeable. We shall see that, accomplished in such a way, it would even be in a sense more real, since one would be following more closely, in a more intimate contiguity, the various gradations by which the surface of the earth is diversified. - Marcel Proust, Remembrance of Things Past
(London: Chatto \& Windus, 1981), vol 1, 693.

... everything in the world exists to end up as a book.

-Stéphane Mallarmé, 'The Book as Spritual Instrument', Divigations (Cambridge, Mass: The Belknap Press, 2007), 226. 



\section{Contents}

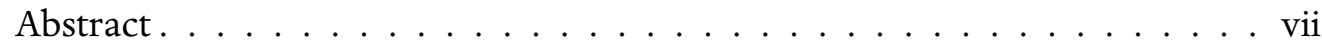

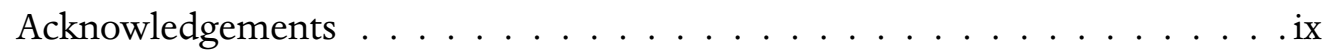

List of abbreviations . . . . . . . . . . . . . . . . xi

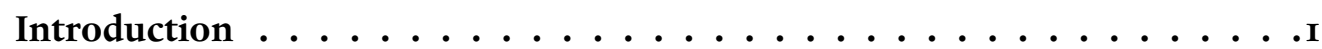

\section{Chapter I}

The Problem of Reproduction: The Origins of the Colour Pictorial . . . . II

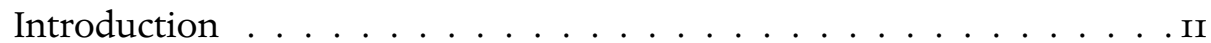

He plunged into the Bush $\ldots \ldots \ldots \ldots \ldots \ldots$

Fragments. . . . . . . . . . . . . . . . . . . . .

For the relief of distress $\ldots \ldots \ldots \ldots$

Humble and submissive handmaids to the text. . . . . . . . . 22

The Photobook. . . . . . . . . . . . . . . . . . . . . . . . . . .

The unkempt negligee of an over-heavily retouched photograph . . . 30

\section{Chapter 2}

Participating in Modernity: Leisure, Mobility, and Consumption. . . . . 35

Introduction $\ldots \ldots \ldots \ldots \ldots \ldots \ldots \ldots \ldots \ldots \ldots \ldots \ldots \ldots \ldots$

The moral tourist. . . . . . . . . . . . . . . . .

Between science and art . . . . . . . . . . . . . . 43

Realism above that noticed even at the actual scene . . . . . . . 48

Christmas in the sun . . . . . . . . . . . . . . .

At home on every roaded mile of New Zealand . . . . . . . . . . . .58

Domesticated pioneers. . . . . . . . . . . . . . . 60 


\section{Chapter 3}

Movement Inward: The Gift of the Colour Pictorial . . . . . . . . . . . . 63

Introduction $\ldots \ldots \ldots \ldots \ldots \ldots \ldots \ldots \ldots \ldots \ldots \ldots \ldots \ldots$

Coffee, table, book . . . . . . . . . . . . . . . . . . .65

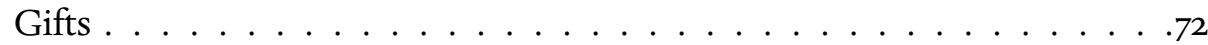

Dreams of home ................... . . 80

Like other folk . . . . . . . . . . . . . . . . . . . 87

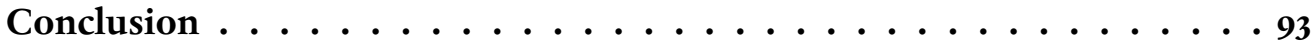

Bibliography . . . . . . . . . . . . . . . . . . . . . . 999

Primary sources . . . . . . . . . . . . . . . . . . . . 999

Secondary literature . . . . . . . . . . . . . . . . . I04 


\section{Abstract}

Published by AH\&AW Reed to immediate success late in 1961, New Zealand in Colour was the first of many large-format books of colour photographs of New Zealand. While they belonged to a tradition of scenic reproduction as old as European settlement, technological changes and the social and economic disruptions of the Second World War intensified the importance of the image in print culture. Drawing on recent historiographic approaches that seek to decentre New Zealand across transnational and city-hinterland relationships, this thesis argues that reproduction, through photography but also as a cultural practice, was intrinsic to a Pakeha conception of place. Looking at scenery was an activity thought to be peculiarly suited to New Zealand, but it was also a prime form of tourist consumption and was therefore essential to New Zealanders' successful participation in modernity, which required 'seeing ourselves' but also awareness of recognition from other moderns. During the decades after the Second World War, modernity took on a more international character with greater mobility of people and goods and a strengthening consumer culture. The complex kinds of looking involved in being modern were increasingly expressed as a tension between modern and anti-modern impulses. The colour pictorial displayed New Zealand as a cultural landscape of cameras, cars, and holidays, but also as a refuge from modernity. The 'coffee table book' was a luxury consumer object of advanced technology, but the gift was the preferred method for its circulation. To be at home with this New Zealand may require a move to the suburbs, but it offers a view of nation and nationalism in which mobility, leisure, and consumption have become the chief explanatory tools. 



\section{Acknowledgements}

Thanks are due to my supervisor Charlotte Macdonald, fellow students in the History programme at Victoria University, the staff at the Alexander Turnbull Library, the Auckland War Memorial Museum Library, Te Papa, and the Hocken Library, John Baxter, Martyn Jolly, Gavin McLean, Ray Richards, and Kirstie Ross, and to my family for giving me this opportunity. It has been a delight. 



\section{List of abbreviations}

$\begin{array}{ll}\text { AJHR } & \text { Appendices to the Journals of the House of Representatives } \\ \text { ANZ } & \text { Archives New Zealand } \\ \text { ATL } & \text { Alexander Turnbull Library, Wellington } \\ \text { AWMML } & \text { Auckland War Memorial Museum Library } \\ \text { Hocken } & \text { Hocken Library, University of Otago, Dunedin } \\ \text { MCH } & \text { Ministry of Culture and Heritage } \\ \text { NZJH } & \text { New Zealand Journal of History }\end{array}$



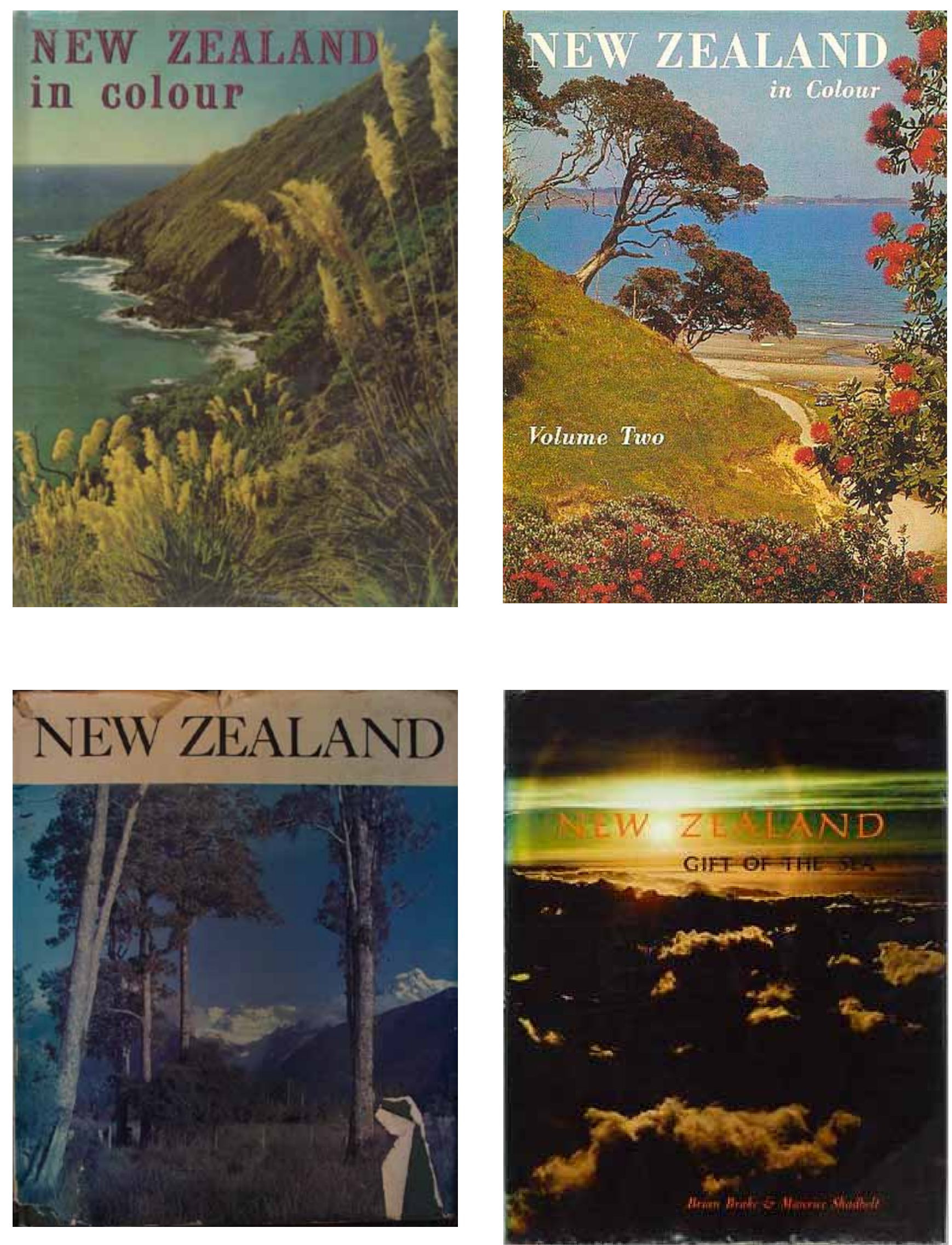


\section{Introduction}

One evening in March 196I, the government steamer TSS Earnslaw left the wharf in Queenstown's sheltered bay and pushed out onto the open water of Lake Wakatipu. You may wish to picture the setting sun colouring the autumn leaves of the poplars that fringed the lake, and picking out the crags of The Remarkables high above. Lake, mountain, and tree cohered to form one of the country's archetypal scenic views. Aboard for a 'social and dance' were New Zealand's booksellers, gathered in Queenstown for their annual conference. Also present was Clif Reed, managing director of the publishing firm AH \& AW Reed. Perhaps it was just such a view that Reed held in his hands as he took a few of the booksellers aside to present a sample of his company's latest project. He had only two plates to show off, but they were large - 12 inches by $\mathrm{Io}$ inches - and printed in Japan with rich colour inks on thick, full-gloss paper using advanced offset technology. ${ }^{\mathrm{I}}$

Back in Wellington, Reed reported to his fellow directors that those who saw the sample plates 'manifested the proper degree of enthusiasm'. 'I think,' he said, 'the people who saw it will talk about it.' ${ }^{2} \mathrm{He}$ was right. Colour books immediately came to the fore of a surge in local publishing. Six years later, the 'books containing full-colour reproductions of photographs and paintings that have achieved a world-wide sale as well as almost fantastic success in New Zealand' introduced Reed's summary of the company's fortunes over the previous decade. ${ }^{3}$ By August 1964, Reeds had printed 68,000 copies of its first colour pictorial, New Zealand in Colour. Three years later nearly I00,000 had been sold, and it remained in print until the late I970s. These figures, Gavin McLean notes in his history of Reeds, are 'extraordinary' by twenty-first century standards. ${ }^{4}$

The most popular colour books were those about and titled New Zealand: the thesis suggests that a specific idea of nation was constituted in the space between Reed's 'world-wide sale' and 'almost fantastic' local success. This space took on an increasingly privatised quality, in keeping with the changes wrought by postwar modernisation. As Clif Reed displayed his images at the booksellers' social, the Earnslaw was embarked on a journey from essential state-funded infrastructure to

\footnotetext{
I Kenneth Bigwood and James K Baxter, New Zealand in Colour (Wellington: A H \& A W Reed, 196I), pl 44, and Kenneth Bigwood and John Pascoe, New Zealand in Colour, Volume Two (Wellington: A H\& A W Reed, 1962), pl 44, show variations on exactly this scene. This study follows Gavin McLean, (Whare Raupo: The Reed Books Story (Auckland: Reed, 2007)) in referring to A W Reed as Clif Reed (but uses A W in footnotes). See A W Reed, report, 'Executive Notes, I96I, II9, Reed Publishing, further papers, MSX-8I04, ATL.

2 AW Reed, 'Executive Notes, 196I', i19.

3 A W Reed, The House of Reed, 1957-1967 (Wellington: A H \& A W Reed, I968), II.

4 McLean, Whare Raupo, II4.
} 
privately-owned 'staged authenticity', only hastened when the road was opened in November 1962 to Glenorchy, at the northern head of the lake. ${ }^{5}$ Pakeha were moving to the suburbs, coming to terms with affluence and disposable income, and embracing mobility by car and jet aeroplane, but they still dreamed of holidaying with their family on an empty beach.

Despite their success, the colour books have received little critical attention. Three reasons for this can be identified. First, because they emphasised illustration rather than text, some questioned their status as books. Secondly, they came to be regarded merely as products for the tourist market. Thirdly, they were coffee table books, a 'form of showing-off [that] is common to all countries in circles where spurious values encourage a reverence for status symbols' ${ }^{6}$ That books have meanings beyond their status as texts, and that books do not only form communities of readers, are ideas that form an important strand of work on print culture. ${ }^{7}$ This study takes the three disparaging judgements just mentioned as launching points to explore the colour pictorials' success in the broader context of New Zealand's cultural history. What can the non-book tell us about the role of print culture in New Zealand's changing relationship with London in the early I96os? How should the success of "tourist" books be reconciled with Pakeha suspicions of tourism and what does this say about their relationship to modernity? What did it mean to display New Zealand on the coffee table?

In 1963, booksellers reported 'something unprecedented in their experience ... never before have bookshops sold so many New Zealand published books so quickly'. ${ }^{8}$ But the local publishing boom in part reflected international developments. After 1945, global book publishing expanded rapidly. In 1965, unEsCo reported that from the mid-I940s to the mid-r96os advances in printing, publishing, and distribution had 'made it feasible to produce low-priced good-quality books on a vast scale'. While Britain remained the largest book exporter, worldwide book production increased by $40 \%$ between 1952 and 1962 , and US production rose by $85 \%$ to rival Japan as the world's fourth largest publishing industry. ${ }^{9}$ How local publishing was affected by global change is beyond the scope of this study, but two points are clear: New Zealand print culture had intimate connections with other places, and, although Britain had been dominant, relationships with Japan and America were strengthening.

\footnotetext{
5 'TSS Earnslaw, History', http://www.tssearnslaw.co.nz/tss-earnslaw/History/. The idea of staged authenticity is central to Dean MacCannell's analysis of the tourist attraction.

6 Alexander Payne, The Coffee Table Coffee Table Book (London: Black Dog, 2003), II.

7 The key texts conceptualising these ideas for this study are: Leah Price, How to Do Things with Books in Victorian Britain (Princeton: Princeton University Press, 2012); Roger Chartier, The Order of Books: Readers, Authors and Libraries in Europe Between the Fourteenth and Eighteenth Centuries (Cambridge: Polity, 1994); Benedict Anderson, Imagined Communities: Reflections on the Origin and Spread of Nationalism, rev ed (London: Verso, 2006).

8 'The Great New Zealand Book Boom', Taranaki Herald, December 1963, Pegasus ms-69, Canterbury Museum, quoted in Noel Waite, 'Adventure and Art: Literature and Publishing in Christchurch, 1934-95', unpublished PhD thesis, University of Canterbury, 1996.

9 The UNESCO Courier (September 1965), 16, 20-2I.
} 
In Queenstown in 196I, Reed told booksellers: 'This was the mood of the moment; New Zealand books had indeed arrived.' ${ }^{\text {Io }}$ By the year's end the sample he had showed them had become New Zealand in Colour. Printed by Kyodo Printing Company in Tokyo, it contained 55 full-page photographs taken by Kenneth and Jean Bigwood of rural, urban, and natural landscapes, beside captions by James $\mathrm{K}$ Baxter. The Japanese firm offered a complete printing and binding service, something local firms could not match. Nor could they compete on price. Something of its success is shown by the change in the company's fortunes between I96I and 1962: income increased from $£_{16,000}$ in April 1961 to $£^{24,000}$ a year later, while costs rose from $£ 22,000$ to $£ 25,000$. More startlingly, the company's bank balance shifted from a $£ 20,000$ overdraft to being $£ 25$,000 in the black.

Clif Reed told his uncle that 'we must make the money work'. In March 1962, after sales manager Tom Kennedy presold 4,000 copies on a three-day visit to the South Island, the directors agreed to a minimum print run of 25,000 copies of New Zealand in Colour, Volume Two, which, with text by John Pascoe, appeared in time for Christmas. ${ }^{\text {II }}$ They also committed to the I44-page, 56-plate, $29 \times 35 \mathrm{~cm}$ New Zealand, known as 'The Big Book', closely modelled on Thames and Hudson's Greece in Colour. It was expected to sell for $£ 55$ /- and the $£ 8,84$ I printing estimate provided by Kyodo would be a significant investment, but Clif Reed told his uncle 'I just can't see such a proposition going wrong provided that we produce a good enough

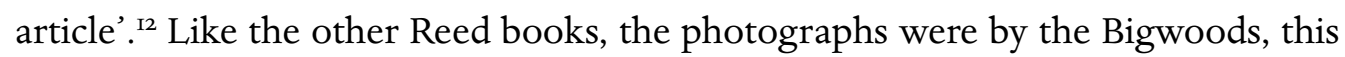
time with an essay on New Zealand society by Monte Holcroft. The company produced many other colour books throughout the 1960s, but these three form the basis of this study, along with Brian Brake and Maurice Shadbolt's New Zealand: Gift of the Sea.

Gift of the Sea was photographically and technically more ambitious, and even more a transnational product. Although published by Whitcombe \& Tombs, Brake controlled production. Based in Hong Kong for Magnum photo agency, he arranged design and production with John Weatherhill Consultants in Tokyo. ${ }^{13}$ Design and typography was by company founder Meredith Weatherby, a Texan who spent long periods in Japan, championed the work of Yukio Mishima in the US, and was the lover of photographer Tamotsu Yato. The colour plates, gravure plates, composition and letterpress, and binding (in unbleached Hakko sailcloth)

\footnotetext{
Io AW Reed, The House of Reed, 1957-1967 (Wellington: A H \& A W Reed, 1968), 20.

II AW Reed to AH Reed, 30 April and 9 March 1962, AH Reed papers, 75-053-4, flr 2, ATL.

I2 Károly Kerényi, Rudolf Hoegler, and Daphne Woodward, Greece in Colour (London: Thames \& Hudson, I957); I Yoshino to Don Sinclair, quotation 62-7-28I, 28 July 1962, A H \& A W Reed records, correpsondence, 79-I53-2I/27, ATL; A W Reed to A H Reed, I9 April I962, Ms-Papers-75-053-4, flr 2, ATL.

I3 Peter Ireland, 'Looking at New Zealand, 1960-1988,' in Athol McCredie, ed, Brian Brake: Lens on the World (Wellington: Te Papa Press, 2010), 250-25I.
} 


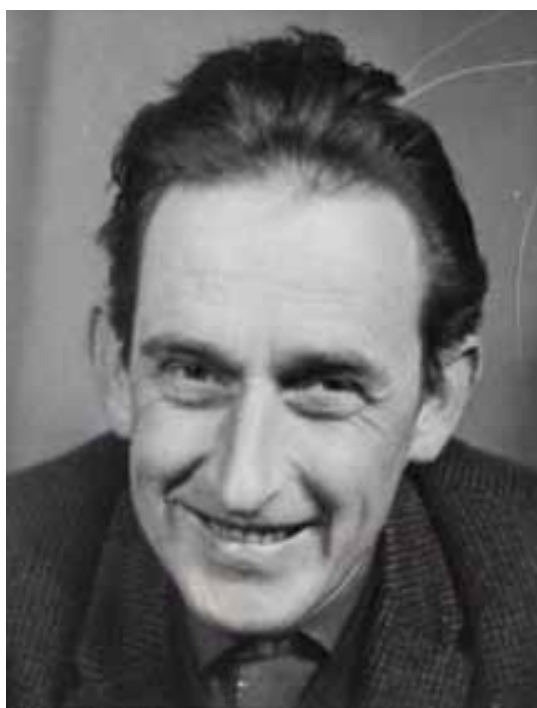

James K Baxter [1960s?] MS-975-234, Hocken.

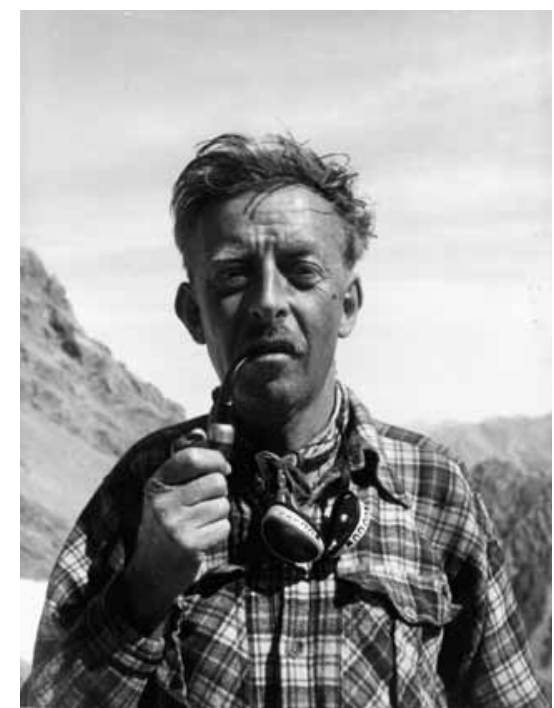

John Pascoe, 1960.

PAColl-6075-04. ATL.

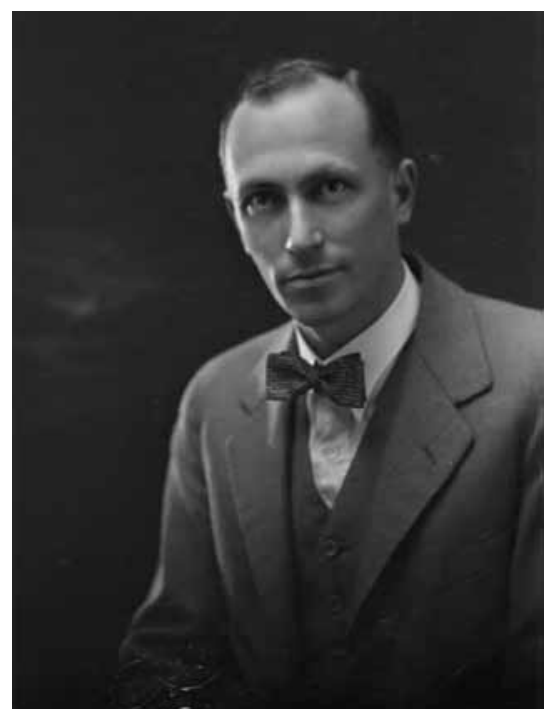

Monte Holcroft, c 1942.

Claude Ring, PAColl-6348-15. ATL.

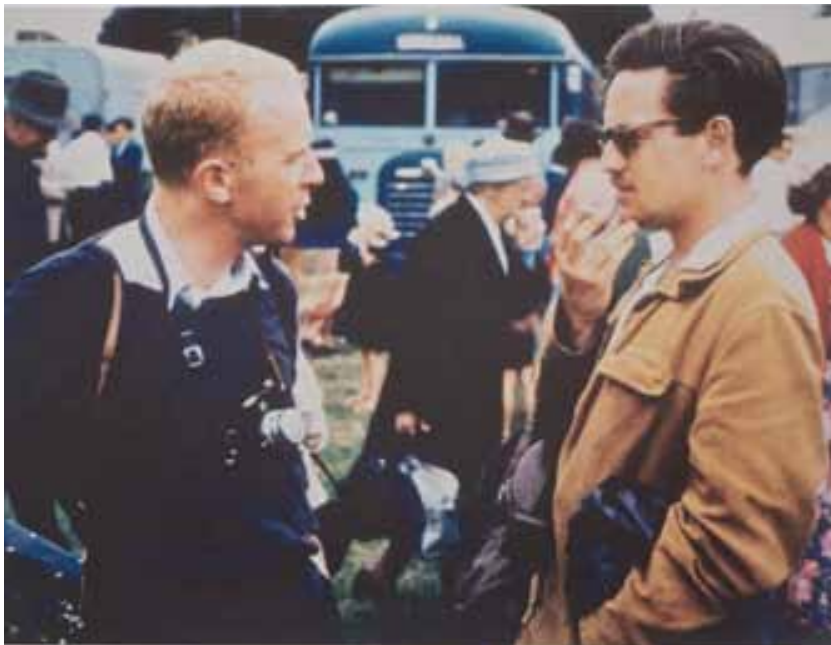

Brian Brake and Maurice Shadbolt, Rotorua, 1960.

Wai Man Lau collection (Brian Brake: Lens on the World, 248).

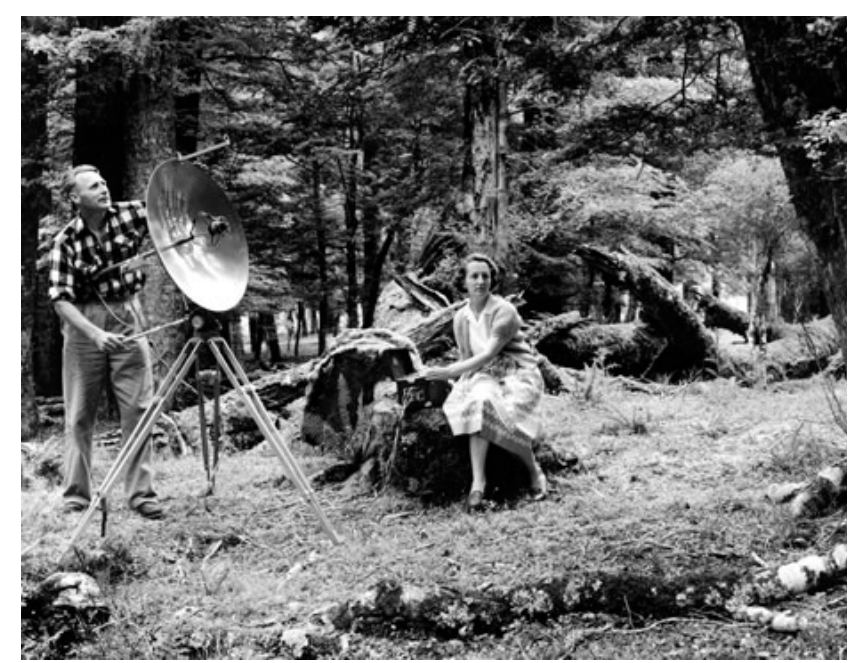

Kenneth and Jean Bigwood recording birdsong [1960s].

Kiwi Records International Ltd (Whare Raupo, 4-5)

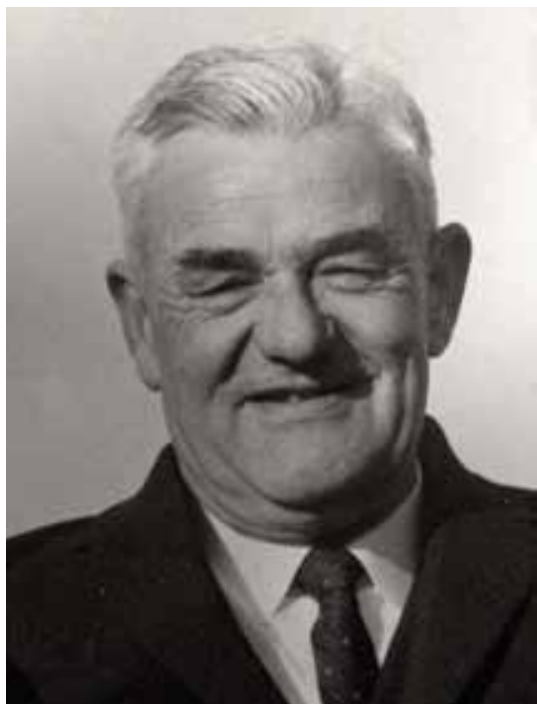

Clif Reed [1960s?].

PAColl-3437, ATL.

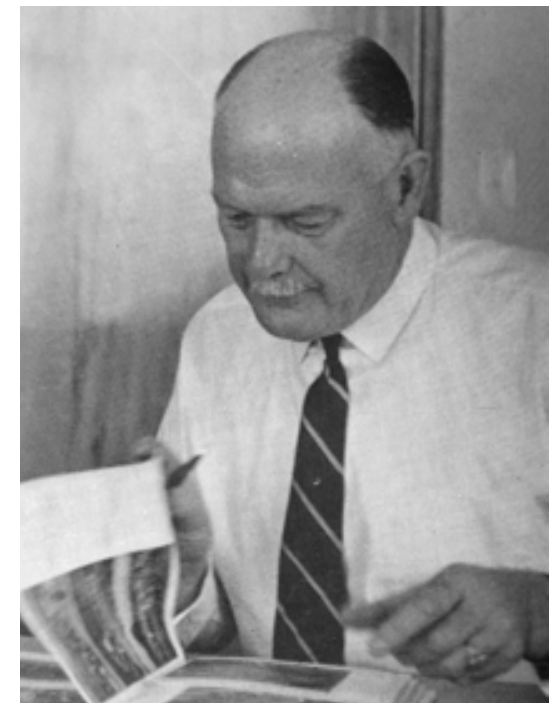

Don Sinclair [1960s].

(Books Are My Business, fig 3).

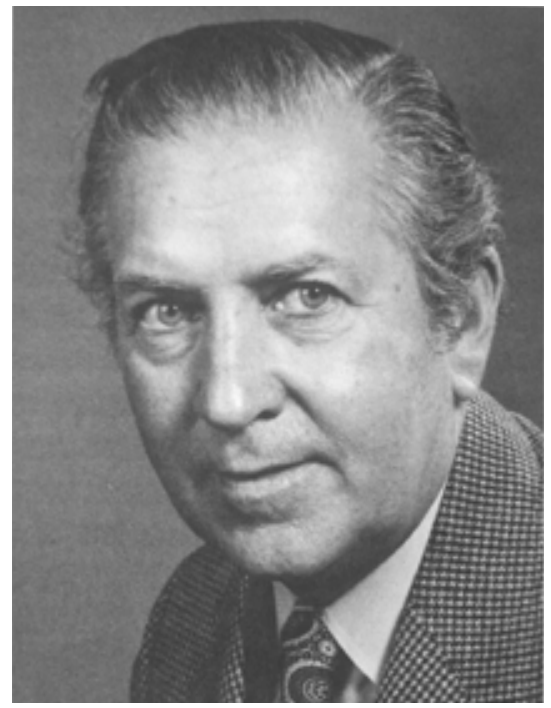

Ray Richards [c 1966]. Ray Richards collection, (Whare Raupo, 140). 
were undertaken by four different Tokyo companies. ${ }^{\mathrm{I}}$ The first September 1963 print run was 13,000 copies, of which 1500 went to London, and the book went on sale in New Zealand on 22 October at a retail price of 35/-. A second printing of 6,000 copies was needed by November, and by the time of the fifth printing in October 1969, 42,000 copies had been produced, including a 'special edition' in I964 for the East-West Center Press at the University of Hawaii. ${ }^{15}$

Booksellers had been asking for a book of colour images of New Zealand scenery for several years. British publishers Collins and Heinemann had sounded out booksellers, without proceeding further. ${ }^{16}$ Recently, Jenny Diski contrasted her memory of the grey I950s with the 1960s, when 'the heart burst with pleasure at the sudden busting out of a full-blown Technicolor world'. ${ }^{17}$ This is memory entwined with print culture: colour reproduction was embraced quickly in the early I960s by publishers and photographers. In 1966, Clif Reed wrote that colour was 'warm, glowing, dynamic. It is typical of the modern age. And it is expensive. Yet within the past few years books have burst into a coruscating blaze of technicolour'. ${ }^{8}$ For Reeds illustrations editor Don Sinclair, colour transparency film required photographers to pay closer attention to their subjects; he warned against 'banal groupings and situations ... for these are colour shots which register exactly what is taken. A different situation from black and whites where darkroom techniques can change the character of a picture to glamourize it or add to its impact.' ${ }^{19} \mathrm{New}$ Zealand Camera remarked, not without irony, that 'this colour business, with its press the trigger technique' had ended the need for photographers to sweat in a darkroom, and brought 'the blissful state of a softer life'. ${ }^{20}$ Colour was desirable, modern, and a more faithful reproduction of reality.

Scenery has always been closely connected with the way that Pakeha saw themselves in the world. The pictorial books emphasised scenery at the expense of people, and rural and natural landscapes over urban scenes. But Sinclair's calculations were based on commercial reasoning that favoured local rather than international sales:

\footnotetext{
I4 Brian Brake and Maurice Shadbolt, New Zealand: Gift of the Sea (Christchurch: Whitcombe and Tombs, 1963), I50; Jeffrey Angles, Interview with Takahashi Mutuo, June 9, 2005, http://intersections.anu.edu.au/issueı2/takahashi_interview.html; Hiroaki Sato, 'Remains of the Occupation Mentality, Japan Times, November 29, 2004, http://www.japantimes.co.jp/opinion/2004/II/29/ commentary/remains-of-the-occupation-mentality.

I5 Whitcombe \& Tombs Publications Register, Australia and New Zealand, I940s-1970s, Whitcoulls Ltd Archive no 2, I878-2008, vol 24, MS 20II/25, AWMMR; Publications Register 1954-I964, Whitcoulls Ltd Archive no 2, I878-2008, vol 2I E2, MS 20II/25, AWMMR.

I6 Sales dept. report for I3 July I960 meeting, 'Executive Notes, I960', 424-425, Reed publishing, further papers, MSX-8IO3, ATL.

I7 Jenny Diski, The Sixties (London: Profile, 2009), 27.

I8 A W Reed, Books Are My Business: The Life of a Publisher (Reading: Educational Explorers, 1966), 88.

I9 Don Sinclair, 'Briefing for New Zealand (Big Book),' undated, A H \& A W Reed records, 79-1532I/27, ATL.

20 GS Powell, New Zealand Camera 9:2 (April-June 1962), 25.
} 
Despite 'dreary shingle' and 'interminable wooden bridges', this image showed New Zealand had the attributes of a modern country. Imperial Album of New Zealand Scenery, 150.

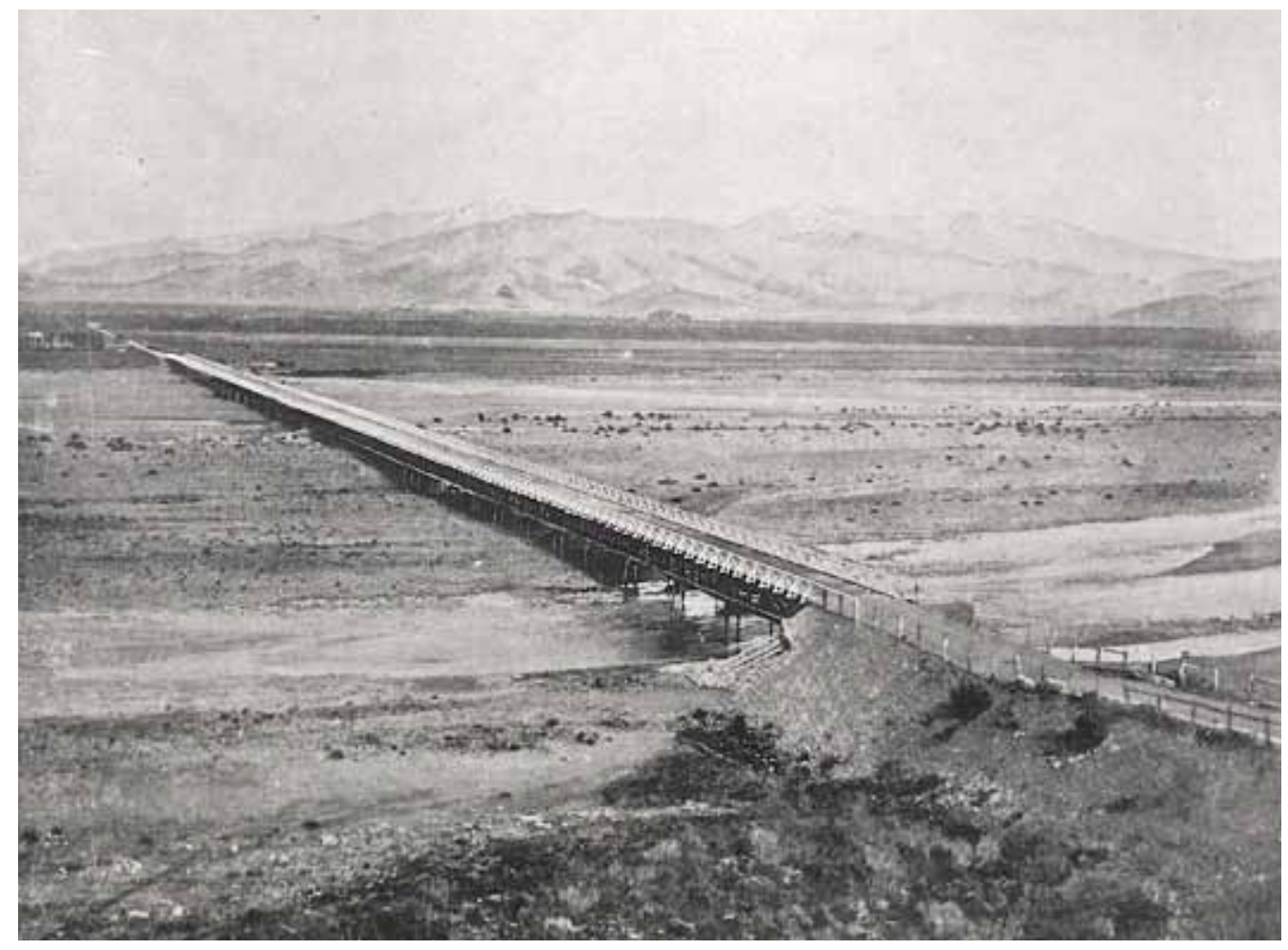

I feel that the public are more important to us than the Public Relations Officers, and I think it is likely that buyers of a book of this sort are better pleased with say, a Manawatu pastoral scene than they would be with a picture of Palmerston North city. ${ }^{2 \mathrm{I}}$

And while scenic images are usually understood as a promotion of the unique properties of New Zealand, this study argues that the opposite was equally true. As a technology of reproduction, photography was well suited to showing how New Zealand was the same. Introducing the Imperial Album of New Zealand Scenery in I899, Robert Stout wrote that New Zealand was just like Switzerland and Norway, while apologising that 'we cannot show the long stretches of petite cultivation that can be seen in the rural districts of England'. ${ }^{22}$ Novelty may have been valued in London, but what Pakeha sought in pastoral scenes, as in iconic scenic views, was familiarity. By 196I, well-cultivated pastoral scenes were plentiful. The importance of pictures of towns, roads, bridges, and the like also lay in their capacity to provoke familiarity. These were scenes of home, but equally importantly they were reproductions - on paper but also in registering 'exactly what is taken' - that demonstrated to Pakeha and anyone else who cared to look that New Zealand was modern.

2I Don Sinclair, report, 8 March 196I, 'Executive Notes, 196I,' 97, Reed publishing, further papers, MSX-8I04, ATL.

22 Robert Stout, preface, Imperial Album of New Zealand Scenery (Wellington: McKee \& Gamble; Wheeler \& Son, I899), vol I. 


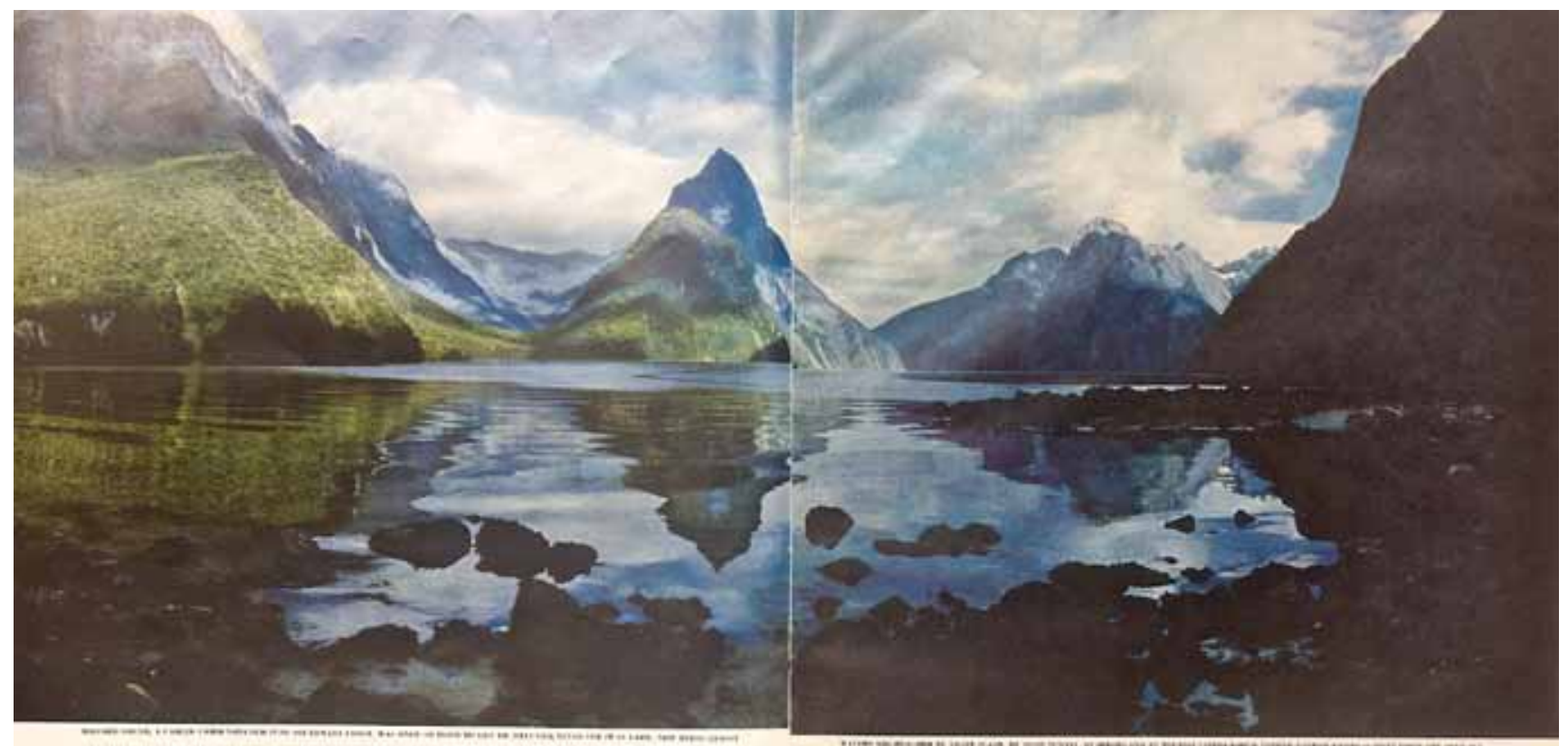

\section{LOVELY LAND}

A nosalgie plostographer poss lack to New Zealand to portray his

No New Zealand subeditor would

The colour books sit, hitherto under-acknowledged, as part of the work of a group of men acknowledged as central figures in the cultural life of mid-century New Zealand. Baxter and Pascoe have received comprehensive biographies. Holcroft and Shadbolt both wrote memoirs. ${ }^{23}$ Baxter's literary papers and the records of his family are held by the Hocken Library, while the Pascoe, Holcroft, and Shadbolt papers are at the Alexander Turnbull Library. ${ }^{24}$ A large book on Brian Brake's life and work, recently published by Te Papa, includes an essay on the production and reception of New Zealand: Gift of the Sea. ${ }^{25}$ The Reed collections at the Turnbull have formed the basis of two histories of the company by Edmund Bohan and Gavin McLean. ${ }^{26}$ Clif Reed may have pinpointed the reason for the colour books' neglect when he praised Holcroft's New Zealand essay as 'just the kind of chatty, have considered this headline for expatriate photographer George Silk's essay on New Zealand in Life International, 28:7 (11 April 1960).

23 Frank McKay, The Life of James K Baxter (Auckland: Oxford University Press, 1990); Chris Maclean, John Pascoe (Nelson: Craig Potton, 2003); MH Holcroft, A Sea of Words: Volume Two of an Autobiography (Whatamongo Bay: Cape Catley, 1986); Maurice Shadbolt, From the Edge of the Sky: A Memoir (Auckland: David Ling, 1999).

24 Baxter family papers, Ms-II36, and James K Baxter literary papers, Ms-0704, Hocken Library; Maurice Shadbolt papers, Ms-Group-I280, John Pascoe's correspondence, Ms-Papers-8I79, and Monte Holcroft's correspondence, Ms-Papers-II86, ATL.

25 McCredie, ed, Brian Brake: Lens on the World.

26 Edmund Bohan, The House of Reed 1907-1983: Great Days in New Zealand Publishing (Christchurch: Canterbury University Press, 2005); McLean, Whare Raupo. See also Gavin McLean, 'Among the Reeds: Using the A H \& A W Reed Collections,' Turnbull Library Record 43 (2010-II), $32-39$. 
interesting introduction that would be appreciated by the minority who read the text of a big presentation book of pictures' ${ }^{27}$ Identifying the other uses that were found for the colour pictorials is a major theme of this study. While histories of reading are an established part of print culture studies, as long ago as 1986, DF McKenzie suggested that it was possible to read visual, oral, performative, and other texts. Against his suggestion that, for Maori, the land is a text, this study suggests that, for Pakeha, the book became a place. ${ }^{28}$ McKenzie's argument for 'the sociology of texts' is extended in Roger Chartier's formulation of 'communities of readers', 'like nomads poaching their way across fields'. Chartier examines the relationship between texts and cultural practices in greater detail in On the Edge. More recently, Leah Price's work investigates the uses of books both within and instead of texts. For a study of books about New Zealand, Benedict Anderson's imagined communities constituted through capitalist print culture are another important reference point. ${ }^{29}$

Understanding the colonisation of New Zealand as a cultural project has been shaped by Peter Gibbons's cultural colonisation thesis, arguing that writing was an important way of asserting colonial power both as 'a sharp instrument' of Treaties and more widely and subtly through the invention and management of Maori and country. That not everything about colonisation could be explained within a framework of extending power and authority was pointed out by Chris Hilliard, who suggested a need for histories of emotion, everyday behaviour, and mainstream cultural norms. Tony Ballantyne has noted 'the primacy attached to the nation in the post-World War II period' as historians 'sought to reconstruct how the processes of "making peoples" produced racial identities, at least those of Maori and Pakeha', and argued that an emphasis on the dispossession of Maori is an 'occlusion' that obscures 'the connections between cultural transmission, [and] the reproduction of Anglo-Celtic models of social organisation and cultural practice'. Felicity Barnes's work on New Zealand's relationship with London in the first part of the twentieth century, and her proposal of a city-hinterland model of provincial relationship, is an important exploration of these issues. This thesis acknowledges Gibbons's emphasis on the importance of writing (and reading) to cultural practices. It takes up Hilliard's suggestion to examine everyday practices

27 A W Reed to Ray Richards, 20 February 1963, A H\& AW Reed records, 79-153-2I/27, ATL. 28 D F McKenzie, 'The Broken Phial: Non-book Texts,' Bibliography and the Sociology of Texts (London: British Library, I986), 23-43.

29 Roger Chartier, The Order of Books: Readers, Authors and Libraries in Europe Between the Fourteenth and Eighteenth Centuries (Cambridge: Polity, 1994); Roger Chartier, On the Edge of the Cliff: History, Language, and Practices (Baltimore: Johns Hopkins University Press, 1997); Leah Price, How to Do Things with Books in Victorian Britain (Princeton: Princeton University Press, 20I2); Benedict Anderson, Imagined Communities: Reflections on the Origin and Spread of Nationalism, rev. ed. (London: Verso, 2006). 
and mainstream cultural norms, but does so in order to suggest an explanation for the postwar primacy of the nation. ${ }^{30}$

The strengthening of a consumer society was perhaps the single most important development in New Zealand society during the decades after the Second World War. Chris Brickell has shown the often highly contested implications of the shift in cultural importance away from work and towards pleasure that accompanied this change. The economic underpinnings of the suburban consumer lifestyle have been explored by Mark Rolfe, who suggests that its promotion and acceptance as the New Zealand (and Australian) "way of life" was American in origin and powered by post-I945 conservative politics. But consumerism requires things, and while the idea that things and their exchange possess cultural power has been traditionally a staple of ethnography, more recently it has been applied to modern consumer societies..$^{3 \mathrm{I}}$ Inquiring into the uses and meanings of the colour pictorials as luxury consumer goods returns this discussion to where it began: doing things with books.

Chapter one briefly surveys the New Zealand scenic pictorial book and emphasises the importance of viewing New Zealand print culture in close relationship with London. The role of illustration in British book culture and the development of the illustrated gift book are canvassed, along with the upheavals of the Second World War, which brought enormous technological and cultural changes to British publishing. The idea of reproduction is proposed as a way of understanding New Zealand's relationships with metropolitan and cosmopolitan cultures. In colonial society, ensuring fidelity to the original was an inherently conservative project that emphasised the importance of British cultural forms and practices. By the I96os, high-quality reproduction could also be a demonstration of the extent to which New Zealand matched British and, increasingly, international standards.

The ways that the colour pictorials show the importance, for Pakeha, of participating in modernity is the theme of chapter two. The question of whether or not the books were tourist products is examined alongside a discussion of Pakeha discomfort with understanding tourism as a commercial transaction. The chapter discusses the implications of the Pakeha understanding that scenery was the way the world saw their country. It explores specific practices - photography,

30 Peter Gibbons, 'Cultural Colonization and National Identity’ NZJH 36:I (2002), 5-I7; Chris Hilliard, 'Colonial Culture and the Province of Cultural History,' NZJH 36:I (2002), 82-97; Tony Ballantyne, On Place, Space and Mobility in Nineteenth-Century New Zealand,' NZJH 45:I (April 20II), 50-70; Tony Ballantyne, Webs of Empire: Locating New Zealand's Colonial Past (Wellington: Bridget Williams Books, 20I2), esp ch I2, conclusion; Felicity Barnes, 'New Zealand's London: The Metropolis and New Zealand's Culture, I890-1940,' (PhD Thesis, University of Auckland, 2008). 3I Chris Brickell, 'The Politics of Post-War Consumer Culture,' NZJH 40:2 (2006): I33-I55; Mark Rolfe, 'Faraway Fordism: The Americanization of Australia and New Zealand during the I950s and I960s,' NZJH 33:I (1999), 65-91. See Kristin Ross, Fast Cars, Clean Bodies: Decolonization and the Reordering of French Culture (Cambridge, Mass: MIT Press, 1995), for an examination of the cultural impact of Fordist capitalism on France. On consumer goods, see Arjun Appadurai, ed, The Social Life of Things: Commodities in Cultural Perspective (Cambridge: Cambridge University Press, 1986), introduction; Bill Brown, ed, Things (Chicago: University of Chicago Press, 2004). 
holidaymaking, and driving - as important markers of modernity and suggests that they were deeply implicated in the idea of nation reproduced in the colour books.

The final chapter returns to the books as objects, and explores how they were understood as luxury consumer goods created for use in the home, whether looked at, thumbed through, written in, displayed on coffee tables, given, received, or read. While they were an acknowledgement that New Zealand's relationships with the rest of the world increasingly extended beyond Britain, the shared practices around the use of the colour pictorial were privatised, domestic, and centred on family. They helped to create a community for whom a New Zealand way of life could be idealised. But if New Zealand belonged in the suburban home, home could be Cape Town or San Francisco as easily as Naenae or Ngaio. The images and text of the colour pictorials, which idealised New Zealand as a refuge from the worst effects of modernity, supported this movement inwards. Caroline Daley has proposed that New Zealand was 'born modern';32 in the colour pictorials, this thesis suggests, New Zealand was also reborn antimodern. Ultimately, this study argues that modernity provided the key terms for national understanding. Participating successfully in modernity was the driving force in shaping a Pakeha identity.

32 Caroline Daley, 'Modernity, Consumption and Leisure', in Giselle Byrnes, ed, The New Oxford History of New Zealand (Melbourne: Oxford University Press, 2009), 423-445. 


\section{The Problem of Reproduction: the Origins of the Colour Pictorial}

\section{Introduction}

... the Editor had conferred with the Directors, and they had come to the conclusion that they could not review it because it was not a book in the generally accepted sense! $!^{\mathrm{I}}$

This was the reason Wellington's Evening Post gave when it retuned Monte Holcroft and Kenneth and Jean Bigwood's New Zealand to Reeds. Or rather, it is the story Clif Reed delightedly told his uncle. Reed then remarked that it would be interesting to know what the thing was, if it was not a book, and that is the question this chapter seeks to answer. Illustrated or pictorial books were not a new phenomenon in the early I960s. This chapter gives a brief account of their history in New Zealand and, necessarily, in London. I will argue that the accurate reproduction of images was an essential part of the colonial project, both in the metropole and on the periphery, and further that reproduction as a cultural practice is an under-appreciated characteristic of colonisation (in the long-view sense of the term advocated by Peter Gibbons ${ }^{2}$ ). Indeed, the importance attached by the Evening Post to the faithful reproduction of the form of the book suggests that acceptance of the importance of reproduction was pervasive, innately conservative, and bound up with ideas about the maintenance of cultural authority.

In 1963 there was laughter in the Reeds office, but the Post seems to have taken a more serious view of its responsibilities. In the time it took to make the short walk from the newspaper's building on Willis Street to AH\& A W Reed on Wakefield, you could reach the town hall, with its magnificent concert auditorium (although the town clock donated in 1922 by Evening Post proprietor John Blundell had long since been removed due to concern over earthquakes), the Grand Opera House, and the Wellington Public Library. The Dominion Museum and the newly

I Clif Reed to AH Reed, 27 December 1963, AH Reed papers, 75-053-4, flr 6, ATL.

2 Peter Gibbons, 'Cultural Colonization and National Identity,' NZJH 36:I (2002), 5-I7; Peter Gibbons, 'The Far Side of the Search for Identity: Reconsidering New Zealand History,' NZJH 37:I (2003), 38-49. 


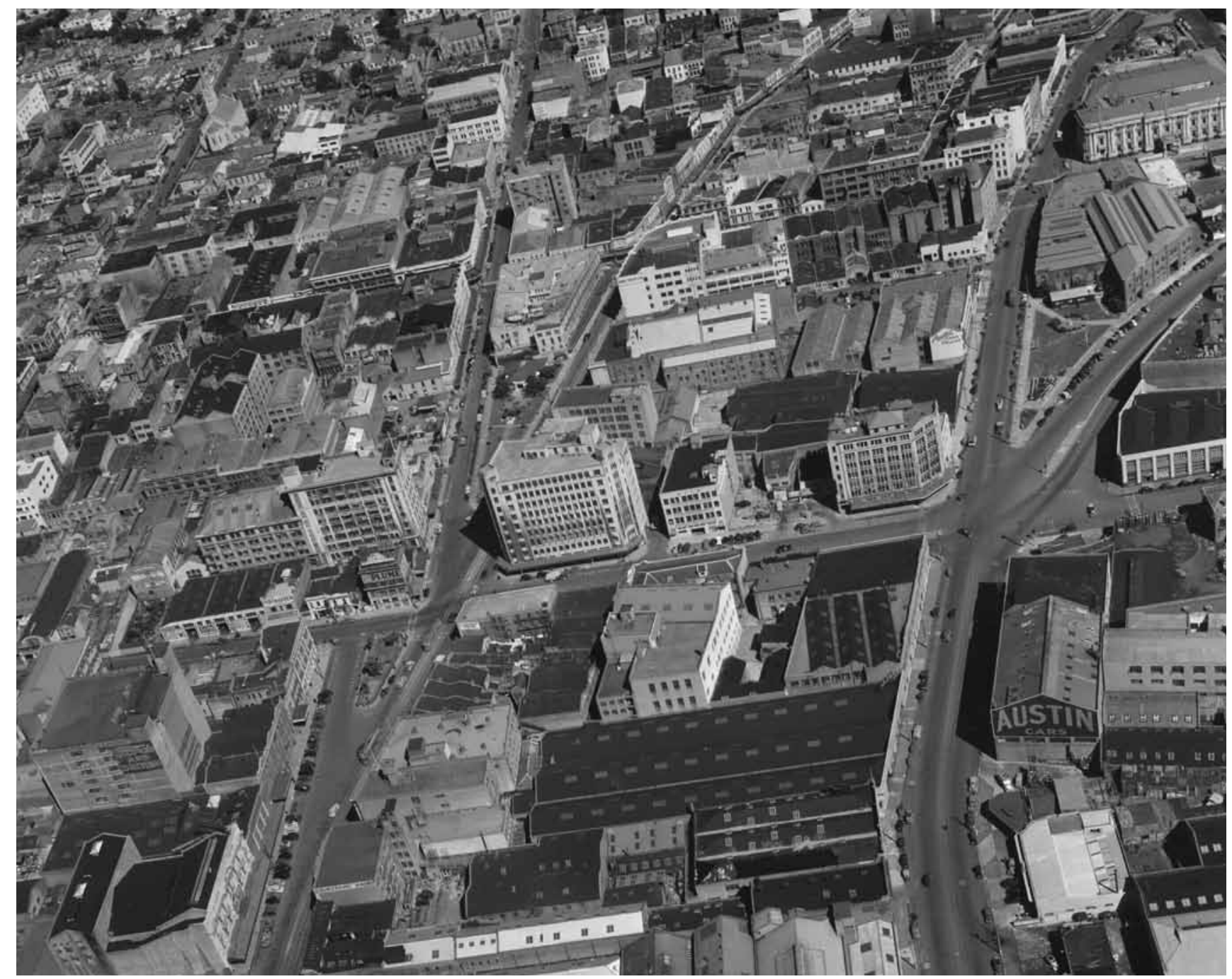

North Taranaki Street area, Wellington, in 1947. The town hall is top right; Reeds' offices were in Wakefield Chambers, on the upper left corner of the major intersection centre right. Whites Aviation photographs, WA-11379-F. AlexanderTurnbull Library, Wellington, New Zealand. http://natlib.govt.nz/records/22866313.

re-named Victoria University of Wellington looked down from their respective hilltops - the latter's title epitomising the nineteenth-century bourgeois municipal culture the Post sought to uphold. The book was the unrivalled instrument for its communication and reproduction, indeed perhaps pre-eminent among the arts in terms of what Eric Hobsbawm calls their privileged status as 'measures of good and bad, as carriers of value: of truth, beauty and catharsis'. ${ }^{3}$

There is a straightforward reply to Reed's question, which is that New Zealand was a publication in which pictures predominated at the expense of the text. Set against the tireless ebb and flow of images that carries contemporary culture, denying it the status of a book now seems astonishing. Maybe an underlying assumption is detectable that literacy extended no further than the alphabet; certainly

3 EJ Hobsbawm, Fractured Times: Culture and Society in the Twentieth Century (London: Little, Brown, 20I3), xiv. 
the chemically or mechanically reproduced image was far from being universally regarded as worthy of serious consideration. Auckland's City Art Gallery had held its first exhibition devoted to photography only in February 1957, displaying the work of Brian Brake. ${ }^{4}$ The National Art Gallery did not begin to collect photographs until $1976 .{ }^{5}$ What are now considered key texts for the analysis of images, and photography in particular, were unknown or unavailable. Walter Benjamin's essay ‘The Work of Art in the Age of Mechanical Reproduction' was written in 1936 but not translated into English until 1968. Roland Barthes' now iconic analysis of the image of a black soldier saluting on the cover of Paris Match - 'whether naively or not, I see very well what it signifies to me: that France is an Empire, that all her sons, without any colour discrimination, faithfully serve under her flag' - written in the late I950s, did not appear in English until $1972 .{ }^{6}$

It would be wrong to suggest that New Zealanders - then finding their own bonds of Empire loosening - were naively uncritical of the meanings of images. What is apparent is a certain lack of analytical sophistication of the sort that theories of 'signification' were providing. At the outset of New Zealand in Colour, James $\mathrm{K}$ Baxter wrote these apparently ingenuous words:

A pattern emerges from the series - not imposed by photographer or writer, but there from the beginning... This book invites you to explore this pattern and come one step closer to seeing New Zealand as she actually is. ${ }^{7}$

It was quite possible, in the early I960s, to give interpretative meaning to images, but it was easier simply to make claims for their naturalism. A notable aspect of the contemporary reaction to these books is precisely how little thought seems to have been given to what the images reproduced on their pages might have to say about their subject. The Dominion's reviewer was content to describe the second volume in the series as comprising 'dramatic shots of scenic grandeur, quiet reflective catpurrings of a drowsy countryside and reach of cloud-boiled sky, occasionally a town'. ${ }^{8}$ In 198I, Kenneth Clark identified 'truth to nature and individual judgement' as 'the recurrent catchwords of provincial art in its struggle to free itself from the dominating style'. By the mid-twentieth century, 'the plain man and the lover of fact' could no longer cut himself off from the world:

\footnotetext{
4 John Turner, 'The Roving Photojournalist,' in Athol McCredie, ed., Brian Brake: Lens on the World (Wellington: Te Papa Press, 20I0), 56-57.

5 Museum of New Zealand Te Papa Tongarewa, 'Topic: Art Photography Collection', http:// collections.tepapa.govt.nz/theme.aspx?irn $=358 \mathrm{I}$.

6 Roland Barthes, Mythologies (London: Jonathan Cape, 1972), II6.

7 Kenneth Bigwood and James K Baxter, New Zealand in Colour (Wellington: A H \& A W Reed, 196I), introduction.

8 'Fine New Volume of N.Z. In Colour', Dominion, 27 September 1962, John Pascoe papers, MS-papers-8179-30, ATL.
} 
Colour reproductions and circulating exhibitions have done for pictorial ideas what printing did for free enquiry in the sixteenth century: and remember that the germ of an idea is as infectious as smallpox; one postcard can infect a whole group. ${ }^{9}$

In the colour pictorial books, photographic reproduction allowed provincial fact to acquire international validity, an idea I will take up in chapter 2. Here I want to point out that a recurring preoccupation - intrinsic to New Zealand's situation on the periphery (or in the hinterland) of a metropolitan culture - was the quality of reproduction. ${ }^{\mathrm{O}}$

Reviewing New Zealand in Colour Volume Two, 'Observer' in the Taranaki Herald initially wondered if the book would reach the standard set by volume one. Happily, the 'new view of Mt Egmont and Lake Mangamahoe, with the mountain wearing an early-summer cloak of snow, may be judged more serenely satisfying than the picture in last year's edition. Here too the Japanese blockmakers and printers have achieved a range of colours as soft as it is true. ${ }^{\text {II }}$ On the other hand, for the New Zealand Herald's reviewer, the printing was clear and the colour true 'except in one view of Mt Egmont where, in the copy under review, the register seems to have gone astray.' 12 The Otago Daily Times thought that 'not all the reproductions are of equal merit. A few disappoint; others delight with their range and sparkle. ' ${ }^{13}$ The Marlborough Express was pleased that the 'exaggerated colouring of some of the scenes' in volume one had been overcome to a large extent. ${ }^{14} \mathrm{JJ} \mathrm{L} S$, in the Hawkes Bay Herald Tribune, wrote that 'with the exception of some colours that appear too powerful to be really a part of the New Zealand scene, it is an excellent example of the printer's art.' ${ }^{15}$ The importance of reproduction is explained well in a review in the Southland Times. Opening with the remark that in these islands of ours we have some of the finest scenery in the world', P M Muller ended by enthusing that 'as a present for friends overseas, this volume could hardly be bettered. As an encouragement for New Zealanders to travel and see their own land, it is likely to prove irresistible. '16 Once again, we seem to have returned to Clark's infectious idea: the link between here and there is made - can only be made successfully - by adhering to the highest standards of reproduction.

\footnotetext{
9 Kenneth Clark, Moments of Vision: \& Other Essays, (New York: Harper \& Row, 1981), ch 4, esp 52, 6I.

Io A second problem, for many reviewers, was the lack of people. The Taranaki Herald begged: 'please, Mr and Mrs Bigwood, if there is to be another picture book let the New Zealander in!' This absence was due to the heavy camera equipment and slow film the Bigwoods used, rather than a conscious aesthetic choice.

II 'Through a Camera Sweetly', Taranaki Herald, I7 October 1962, Pascoe papers, MS-papers-8I79-30, ATL.

I2 'Another Tour Finds Fresh Beauty', New Zealand Herald, 8 September 1962, Pascoe papers, MS-papers-8I79-30, ATL.

I3 'New Zealand in Colour', Otago Daily Times, ro October 1962, Pascoe papers, Ms-papers-8I79-30, ATL.

I4 Marlborough Express, I7 October 1962, Pascoe papers, Ms-papers-8179-30, ATL.

I5 Hawkes Bay Herald Tribune, I5 September 1962, Pascoe papers, Ms-papers-8179-30, ATL.

I6 PM Muller, 'New Zealand in Colour', Southland Times, I5 September 1962, Pascoe papers,

MS-papers-8I79-30, ATL.
} 
In 1968 John Pascoe wrote to the editor of the Press in a 'mood of complaint', asking why his New Zealand in Colour from the Air had not been reviewed:

As a former Christchurch joker and former reviewer on your literary page I do not ask for favourable reviews, or boring 'local boy makes good' stuff. I do however think that a New Zealand writer of my experience (this is my I4th book or nonbook) is entitled to have a substantial work noticed, even if the reviewer says the photos stink and the text is lousy. ${ }^{17}$

The editor's reply helpfully defined the non-book: 'The usual practice with art or art-and-text books (non-books), is to print a striking picture from their pages and to describe it briefly in the caption'. But the real reason for the non-review, he went on to say, was that if we were to review the book we would have to say that it contained some appallingly bad colour reproduction'. Launder, the editor of the Press's books page, had 'felt it would be kinder . . . to say nothing'. ${ }^{8}$

In fact, the non-book has had a long and various history. What follows are investigations of some of the varieties of non-book, which together tell a story that helps to explain how by 196I the large-format colour pictorial could flourish. In colonial (and recolonial) New Zealand, print culture was inseparable from the ambition to reproduce Britain. The changes in the illustrated book, particularly from the 1930s, were one aspect of a larger cultural shift, broadly identifiable as the first stirrings of consumer-led mass culture. While London largely retained its cultural authority, it changed as it absorbed European and American influences and became a global city rather than the seat of an empire. If the ideal of colonial reproduction became less and less tenable, reproduction itself, especially of scenery, retained a leading role in Pakeha culture as a guarantee of participation in this new development of modernity.

\section{He plunged into the Bush}

Illustrated books were not a new phenomenon. In New Zealand, they have a past that spans the history of European settlement. George Cooke's engravings of Scenes of the East India Islands, Etc, from I8I3, is the earliest of more than 600 books in the National Library of New Zealand catalogued under the subject heading 'New Zealand - Pictorial works'. ${ }^{19}$ Nineteenth-century examples are scarce until the later part of the century when photography entrenched itself as the favoured visual medium for imitating nature. Either side of 1900 there was a flurry of Albums - the Imperial Album of New Zealand Scenery ran to several editions - and thereafter titles grew ever more extravagantly phrased. In the ig2os, for example, Frederick Radcliffe found Beauty Spots in 'God's Own Country': Gems of New Zealand

\footnotetext{
I7 John Pascoe to Roly Cant, I2 November 1968, Pascoe papers, Ms-papers-8I79-25, ATL. I8 Roly Cant to John Pascoe, 20 November 1968, Pascoe papers, Ms-papers-8179-25, ATL. 19 George Cooke, Scenery of the East India Islands, etc.: A Series of Views of the Most Remarkable Localities, Celebrated for Picturesque Beauty or Historical and Other Associations (London: Longman, Hurst, Rees, Orme \& Brown, I8I3).
} 


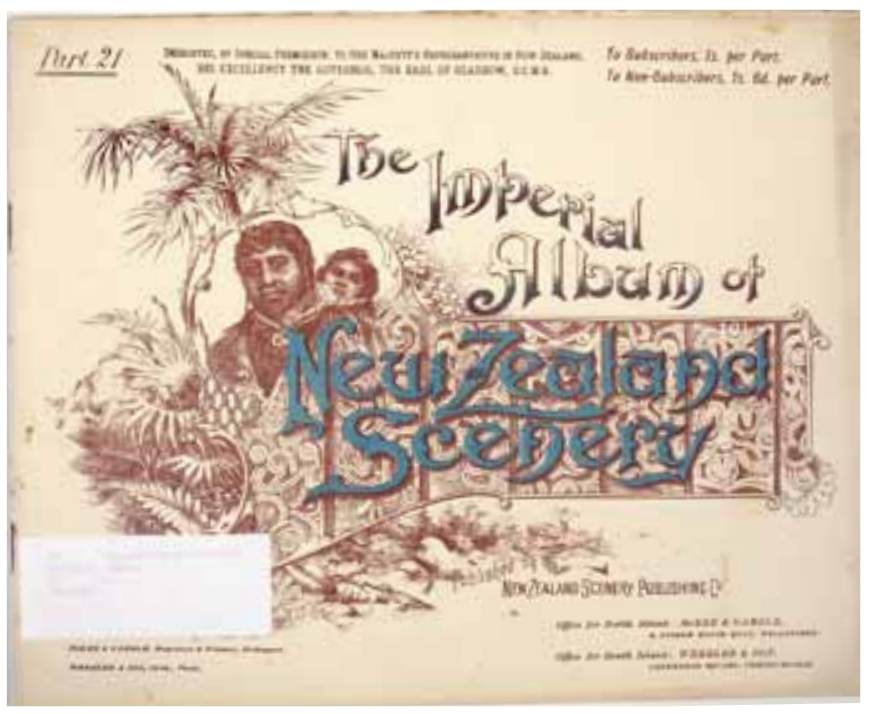

The Imperial Album of New Zealand Scenery, part 21 of 24. A hardcover edition later combined all the parts with a preface by Robert Stout.
Scenery. ${ }^{20}$ In that decade twenty-eight 'New Zealand - Pictorial Works' were published, although in the Depression years of the i93os there were only ten, almost all products of the Government. For the Tourist Department, 'scenic playground' was a suitable subtitle; the Department of Industries and Commerce preferred 'Britain of the south'. The rg40s saw a few more, though now not State-sponsored: five dating from 1940 presumably sought to cash in on the centennial celebrations; and the first collection of photographs 'from the air' published by DN Adams in Christchurch made four appearances in various editions and reprints, predating the better-known Whites Pictorial Reference of New Zealand by a decade. By far the greater number of these 'Pictorial Works' was published in New Zealand, but they were not books in the traditional hardcover sense. Rather, they were pamphlets, brochures and souvenirs with card or soft covers, typically a few dozen pages long.

It was during the 1960s that 'New Zealand - Pictorial works' really took off. As Peter Ireland put it: 'This trickle of books mythologising New Zealand became a black and white stream after the First World War and a flood in colour after 1960.' ${ }^{21}$ There were Io such books published in the last half of the I950s, but 2I between I960 and 1964 and 47 for the decade as a whole, or roughly a quarter of the entire production up to that point. The numbers alone suggest the change that took place

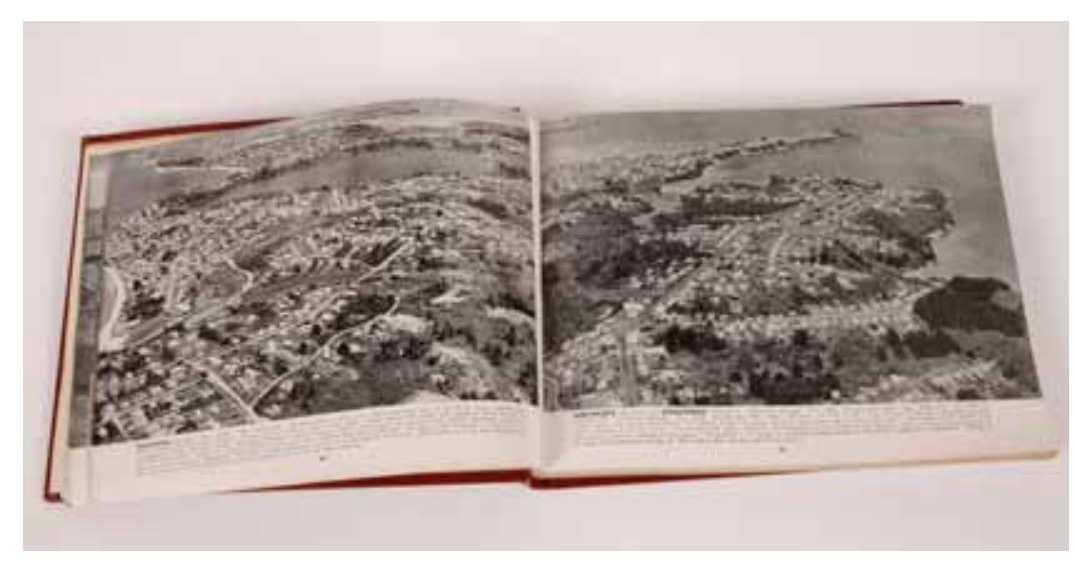

Leo White, Whites Pictorial Reference of New Zealand (Auckland: Whites Aviation, [1953]). http://www.webbs.co.nz/files/2935.jpg. during that decade. That change, itself a reflection of change in the way Pakeha understood their place in relation to the world, is the major preoccupation of this study. But there was also continuity, which warrants a brief visit to those first years of the illustrated book.

Samuel Brees arrived in Wellington in February 1842 and worked until May I845 as the New Zealand Company's principal surveyor and engineer. After his return to London,

20 The Imperial Album of New Zealand Scenery, 24pts (Wellington: New Zealand Scenery Publishing, [1896-I899]); Frederick Radcliffe, Beauty Spots in 'God's Own Country': Gems of New Zealand Scenery (Auckland: Frank Duncan [1920]).

2I Peter Ireland, 'Looking at New Zealand,' in McCredie, Brian Brake, 246. 
many of the pencil and watercolour sketches he had made were engraved and then published in I $847-49$ as Pictorial Illustrations of New Zealand, which Brees described as 'a most beautiful Drawing-room book'.22 Books of this sort were far from cheap. The original price was two guineas, subsequently reduced to $£$ I IIs $6 \mathrm{~d}$ for later issues. A more widespread audience was reached by his 'Colonial Panorama' of New Zealand, displayed in Linwood Gallery in London's Leicester Square during I850 and I85I with a basic admission price of one shilling. Panoramas originated in the late eighteenth century as large-scale paintings, on the scale of and adapted from the techniques of theatre scenery, set up to slowly revolve past their audience. Travel to foreign countries was their stock in trade, and Charles Dickens gently satirised the phenomenon in the 'panoramaniac' character of the retired Mr Booley, possibly a former bank clerk: 'His countenance is florid, he is perfectly bald, and soon hot'. Late in life, Mr Booley developed a passion for travel. After voyaging up the Mississippi River from New Orleans to the Rocky Mountains, he returned to London, only to depart for Wellington, where, 'After participating in an affray between the natives and the English soldiery, in which the former were defeated with great loss, he plunged into the Bush, and there camped out for some months, until he made a survey of the whole country. ${ }^{23}$

Richard Altick explicitly compared his 1978 history of the panorama to his earlier study of the 'mass reading public' in nineteenth century England. ${ }^{24}$ But

22 Samuel Brees, quoted in A G Bagnall, et al. 'S C Brees: artist and surveyor', Turnbull Library Record I:4 new series (November I968), 36-53.

23 Charles Dickens, 'Some Account of an Extraordinary Traveller', Household Words, 20 April I850 (leading article), in Michael Slater, ed., Dickens' Journalism: The Amusements of the People and Other Papers: Reports, Essays and Reviews 1834-51, (London: J M Dent, 1996), 203, 206. The term 'panaromaniac' comes from the title of a 1988 exhibition at the Barbican Art Gallery, London: Slater, Dickens' Journalism, 201.

24 Richard Altick, The Shows of London (Cambridge, Mass: Belknap Press of Harvard University Press, 1978); Richard Altick, The English Common Reader: A Social History of the Mass Reading Public, 1800-1900 (Chicago: University of Chicago Press, I957).

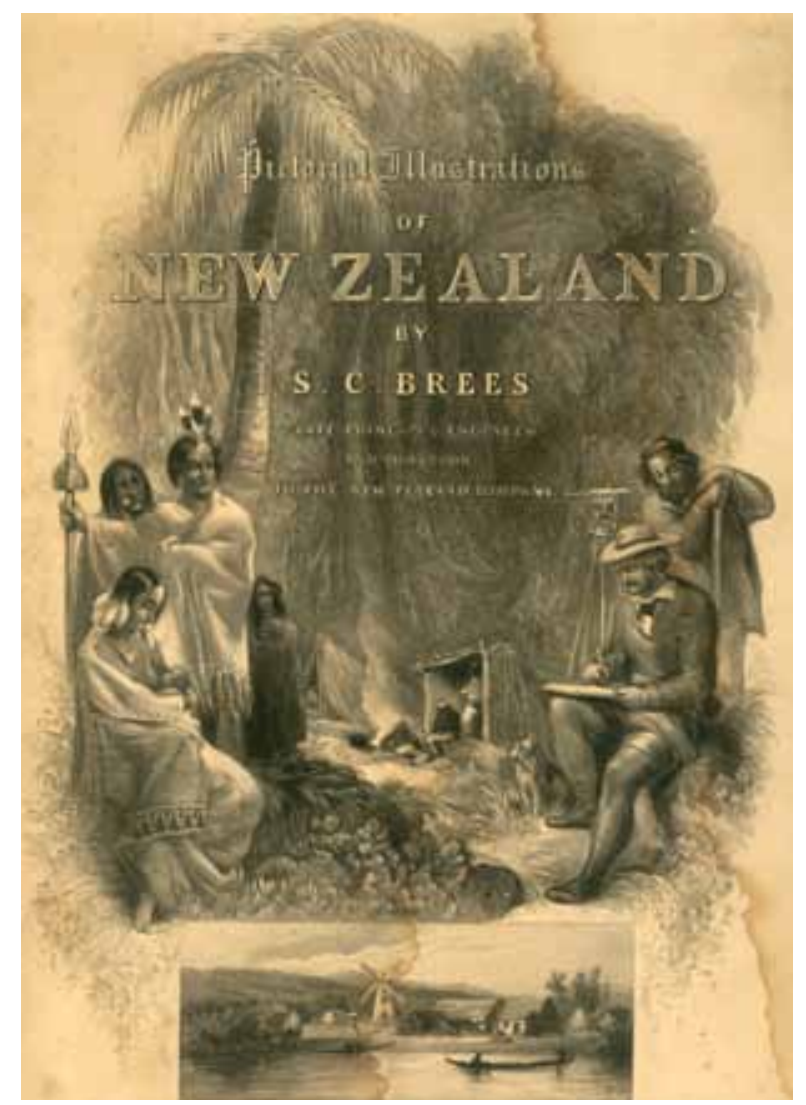

SC Brees, Pictorial Illustrations of New Zealand (1849). http://www.enzb.auckland.ac.nz/document/?wid=1453.

Poster advertising Brees's 'Colonial Panorama' (1850-51), in Richard Altick, Shows of London, 426.

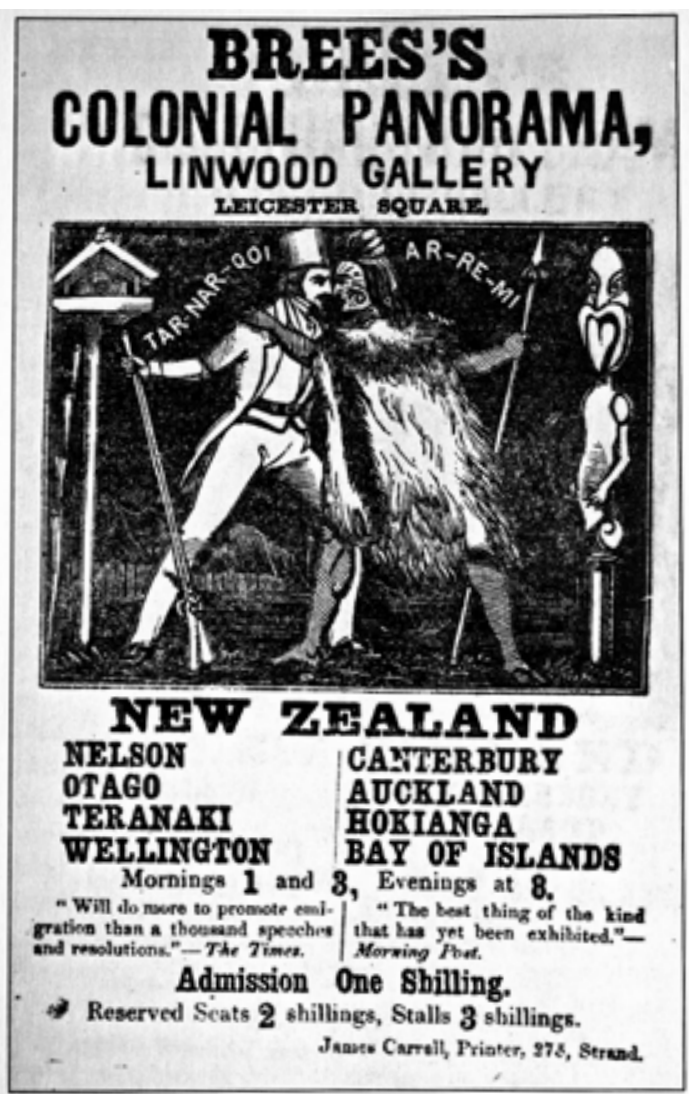


the later work had a considerably wider scope: 'It is concerned with the habits and experience not only of that portion of the population who had access to the printed word and took advantage of it, but also of that much larger number of people who either could not read or simply were disinclined to do so.' Which meant everyone from the Duke of Wellington down: 'curiosity was a great leveler'. Pictures and print alike satisfied 'the desire to be amused or instructed, the indulgence of curiosity and the sheer sense of wonder, sometimes a rudimentary aesthetic sensibility'. ${ }^{25}$

Vital to the panorama was fidelity to nature, as Dickens had noticed. Before turning his mind to the invention of the Daguerrotype, Louis Daguerre exhibited his own variant, the diorama, which comprised enormous transparent paintings up to 22 by 14 metres in size, displayed under changing lighting conditions. ${ }^{26}$ Of his 1832 'View of Mont Blanc taken from the Valley of Chamonix' one viewer said: 'Here is an extraordinary mixture of art and nature, producing the most astonishing effect, so that one cannot decide where nature ceases and art begins. ${ }^{27}$

After about 1850 the enthusiasm for panoramas waned quickly in London, but it sustained a lengthy afterlife in the developing colonies until the end of the nineteenth century. In a neat inversion of imperial space, the two-hour-long 'Mirror of England' showing the Thames from its source to the Tower of London was shown in Wellington in I876. The Evening Post enthused that it was a 'moral, instructive, and intellectual as well as an artistic treat' ${ }^{28}$ Altick marks the Great Exhibition of I85I as the beginning of the end, and attributes their demise to the development of museums and the State's reluctant acceptance of responsibility for mass education and 'uplift'. ${ }^{29}$ Colligan suggests that in the colonial context it was the movies that 'drove cycloramas and moving panoramas from the popular memory'. ${ }^{30}$

An explicit link can be made between the panorama and the mid-twentieth century illustrated book. An I846 panorama at the Egyptian Hall featured the work of George Angas and promoted his father's South Australia Company. The accompanying book, The New Zealanders Illustrated, also published in I846, became the subject of a facsimile edition in 1966. Taking advantage of their relationship with the Japanese printer, Kyodo, who printed their In Colour books, Reeds pre-sold 750 copies a year in advance at 65 guineas apiece. Avon Fine Prints brought out a facsimile of Brees's Pictorial Illustrations in 1968.

In I847 those who could afford a 'beautiful Drawing-room book' were few in number and the panorama offered a means of bringing illustration to a wide audience. In post-I945 consumer society a New Zealand pictorial book could sit on

\footnotetext{
25 Altick, The Shows of London, I-3.

26 Helmut Gernsheim, LJM Daguerre: The History of the Diorama and the Daguerreotype (New York: Dover Publications, 1968), I4.

27 Quoted in ibid, 3r. Daguerre had brought a real goat, chalet, and fir trees back to Paris from Chamonix.

28 Evening Post, I6 September 1876, quoted in Mimi Colligan, Canvas Documentaries: Panoramic Entertainments in Nineteenth-century Australia and New Zealand (Melbourne: Melbourne University Press, 2002), 83.

29 Altick, The Shows of London, 4.

30 Colligan, Canvas Documentaries, 217.
} 
almost any coffee table. But other comparisons present themselves. Both brought visual impact, popular appeal, and a mixture of amusement and instruction to audiences disinclined to read. As the peregrinations of Mr Booley suggest, the relative absence of any didactic institutional voice made it easier for viewers to experience direct personal engagement with what they saw. Altick's remark that the panorama brought relief from the dullness, vacuity and constriction 'which were too often the price of life in the enveloping city' suggests an antimodern ethos that could also be applied to the colour pictorial book. Perhaps the point to observe here is the manner in which the continuities of urban experience have conditioned the presentation of the image and the thing we know as New Zealand. In the panorama - morphing into the drawing-room book, populist and non-literary, indulging amusement and desire - the origins of the non-book are clearly on view.

\section{Fragments}

Books published in New Zealand make up only a part of this narrative. London, the centre of the publishing world, had long formed 'a necessary extension of local and insufficient cultural borders', as Felicity Barnes writes. ${ }^{3 \mathrm{I}}$ Within these extended borders reciprocity was limited. This was because, first, the forms rather than the content were considered as models for reproduction. In the metropolis, "New Zealand" could be and was substituted for almost any other point on the globe. Secondly, it was not necessary (although for many it was desirable) to physically travel to London. Books, the cultural commodities of the cultural capital, came to New Zealanders in vast quantities. While exact figures are unclear, of the $£ 3.378 \mathrm{~m}$ of books, magazines, newspapers and music imported in 1960, 57 per cent came from the United Kingdom (a further 28 per cent came from Australia). ${ }^{32}$ In Australia, which was generally treated by London together with New Zealand as a single market, PR Stephenson said in 1962: 'In so far as the mind of a nation is conditioned by reading matter, the minds of Australians are conditioned 90\% by imported books. ${ }^{33}$ This was not equivalent to saying that the minds of Australasians and Londoners were 90 per cent the same, not least because not all titles travelled to the antipodes. But describing the peculiarly incomplete fragment of modernity that existed in Wellington must depend, to a large degree, on knowing what books (and what kinds of books) arrived from London. Perhaps equally as important were the memories, beliefs and opinions about print culture that people carried with them, for which London remained the primary authority.

3I Felicity Barnes, 'New Zealand's London: The Metropolis and New Zealand's Culture, I890-I940' (PhD thesis, University of Auckland, 2008), I26.

32 Department of Statistics, New Zealand Official Year-book 1963 (Wellington: Government Printer, I963), sec 22C, http://www3.stats.govt.nz/New_Zealand_Official_Yearbooks/I963/NZOYB_I963. html.

33 Quoted in Penny Griffith, Ross Harvey, Keith Maslen, Book and Print in New Zealand

(Wellington: Victoria University Press, I997), II7. 
That authority engendered an inherently conservative relationship, which valued tradition over innovation. The firm of Allen $\&$ Unwin might be taken as representative. It was headed by Sir Stanley Unwin, who had relatives living in Timaru and who visited New Zealand in 1949. In 1939 he had published John Pascoe's first book, Unclimbed New Zealand. Two plates of what was admittedly for the time fairly cutting edge colour reproduction were included, but even by 195I the firm's business procedures seem to have retained a decidedly nineteenth-century character:

The place was Dickensian, its ledgers and orders written by hand. ... There were spy-holes for Stanley to see what was going on, and visitors could become lost, perhaps straying into the packing department, where labels were glued on to secondhand cardboard boxes which were tied up with string. ${ }^{34}$

John Harthan, formerly librarian at the Victoria and Albert Museum in London, points to the I880s as the moment when 'ordinary book buyers . . began to treat illustrated books rather more as precious objects and less as objects of use'. ${ }^{35}$ This development coincides with the moment when when consumption began to take up its central place in the lives of the middle class. ${ }^{36}$ The debate over whether consumption ought to be embraced or repudiated was in some respects mirrored by the two distinct forms the illustrated book adopted. A revival of hand craftsmanship, exemplified by William Morris, produced the cult of "The Book Beautiful" and was a precursor to the Aesthetic Movement - art for art's sake - championed by Oscar Wilde and Aubrey Beardsley. Among commercial printers and publishers, advances in colour printing and photographic reproduction gave new impetus to the gift book. ${ }^{37}$ Both, albeit for slightly different reasons, risked accusations of self-indulgence. While the acquisition of things might benefit the economy, unrestrained pleasure-seeking might lead to decadence or worse.

\section{For the relief of distress}

The gift book is susceptible to broad and various definitions. Harthan tends to equate it with the "genteel book": popular, middlebrow, commercially produced and frequently reflecting nostalgia for a vanished past. In particular, he suggests that images of nature became especially attractive when 'the countryside itself was about to be ravished by the motorcar'. ${ }^{8}$ The full-colour, full-page display of Arthur Rackham's illustrations for Peter Pan in Kensington Gardens (1906) or Edmund Dulac's for the Rubaiyat of Omar Khayyam (1909) confirmed the importance of the

\footnotetext{
34 Anthony Smith, obituary for Rayner Unwin, Guardian, 27 November 2000.

35 John Harthan, The History of the Illustrated Book: The Western Tradition (London: Thames and Hudson, 1981), 228.

36 'Introduction,' Richard Wightman Fox and TJ Jackson Lears, eds., The Culture of Consumption:

Critical Essays in American History, 1880-1980 (New York: Pantheon Books, 1983), ix.

37 Harthan, The History of the Illustrated Book, 228.

38 Ibid, 238-239.
} 
illustration to such books. They used photo-mechanical processes of reproduction developed in the i88os: colour half-tone blocks were made up and printed in four colours on to sheets of thick gloss paper that were then "tipped in" - each one separately pasted into the book.

The American historian Stephen Nissenbaum concentrates more on the act of giving than the gift books' intrinsic value. He identifies gift books as 'the very first commercial products of any sort that were manufactured specifically, and solely, for the purpose of being given away by the purchaser'. ${ }^{39}$ They were invented specifically to be linked to the Christmas season, a heterogenous mixture of poetry, essays and pictures that flourished in the United States 'for little more than a single generation as a genre, from 1825 to $1860^{\circ} .4^{\circ}$

The term gift book features frequently in the language of New Zealand booksellers' advertisements, but somewhat later. The gift book seems to have attained a height of popularity in New Zealand from the late I86os until the First World War, and a particular form of the genre gained widespread notice. In 1909, the Star in New Zealand reproduced a leading article from the Queen which praised Queen Alexandra's Christmas Gift Book for showing how even a pleasant and pleasure-giving hobby may be turned to good account for the poor and suffering' by producing a 'personal and practical gift'. ${ }^{4 \mathrm{I}}$ The Queen's hobby was taking photographs, and the Otago Daily Times thought the act of 'permitting their reproduction and world-wide distribution is that of a kindly lady showing friends her own album'. The book was intended to benefit the unemployed, and 'wealthy persons and corporations' bought many copies for 'presentation purposes'.$^{42}$ In 1915 , Princess Mary's Gift Book was, as the Otago Daily Times put it 'among the many ingenious and splendid schemes which [the Royal family] have set on foot for the relief of distress and the assuagement of suffering caused by the war'. Its illustrations, not least the frontispiece portrait of the princess, were 'gems of colour' ${ }^{43}$ But the gift book endured at least until the Second World War. In 1929 the Evening Post reprinted a 'Book Buyer's Index' from the Manchester Guardian, in which:

$\mathrm{G}$ is for Gift Book, a Christmas memorial

That's usually highly ornate and pictorial.

On the other hand, $\mathrm{H}$ was for highbrow: 'few keep a kind look for him - and care should be taken in buying a book for him.' ${ }^{4}$

39 Stephen Nissenbaum, The Battle for Christmas (New York: Vintage Books, 1997), I43.

40 Ibid, I50.

4I Auckland Star, 20 February 1909, I.

42 Otago Daily Times, io December 1908, II.

43 Ibid, 6 February 1915, 2.

44 Evening Post, 30 November 1929, 2 I. 
Personal message from Olive Newall in the front of Lady Newall's New Zealand Gift Book (Wellington: PEN, 1943).

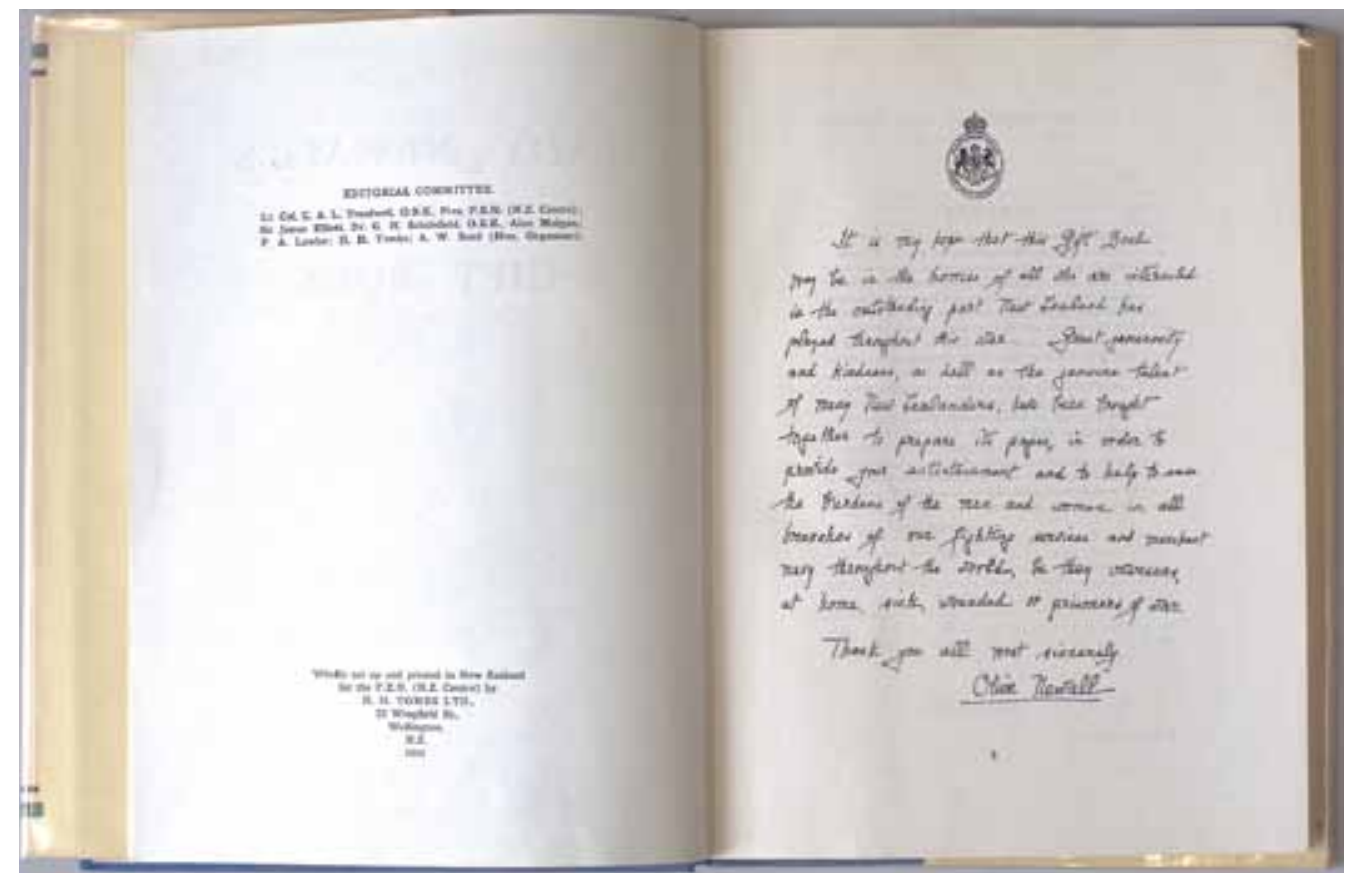

While these were British productions, the last gift book of note sold in New Zealand was locally produced. Following the established formula, Lady Newall's New Zealand Gift Book was organised on behalf of the governor-general's wife by the New Zealand branch of PEN and by May 1945 had raised more than $£$ I,IOo for the National Patriotic Fund Board. Its 'Honorary organiser' was Clif Reed and, with illustrations by Peter McIntyre, C F Goldie and George Angas, and stories by Pascoe, Holcroft, Pat Lawlor and Leo Fanning, among many others, it suggested the kind of work that after the war would bring Reed's firm such success.

\section{Humble and submissive handmaids to the text}

The second type of illustrated book as precious object occupies more complex moral terrain. Typically hand-set on letterpress and displaying engraved woodcut illustrations, they embodied an ethos of hand-crafted excellence that stood self-consciously in opposition to mechanical and photographic processes. These ideals were most fully realised in the private press movement pioneered by William Morris in the I89os. Morris's Kelmscott Press edition of The Works of William Chaucer was irreducibly English in character but also praised as the most beautiful book of its time. ${ }^{45}$ Nonetheless, an Anglo-Saxon (or perhaps Pauline) distrust of the image may account at least in part for the tradition in English publishing that, as early twentieth century sculptor, engraver and letter-cutter Eric Gill put

45 David Cody, 'Morris and the Kelmscott Press', The Victorian Web, http://www.victorianweb. org/authors/morris/kelmscott.html. This book had something else in common with the coffee table book - 'Charles Ricketts complained that a lectern was necessary in order to read it': Harthan, 230. 
it, illustrations should illustrate, clarify and illuminate the text and were no excuse for outpourings of sensibility. ${ }^{46}$ This basic truth about illustration is evident from the primary meaning of the word, which is to explain or make clear by way of example. Gill continued Morris's belief in the intrinsic rewards of fulfilling work, restrained design and committed craftsmanship. He was explicit about his Anglocentrism. In An Essay on Typography in 193I he lamented that 'it is industrialism that is the body of our modern world', but restricted his argument to England: 'it may be that the conditions are much the same in France, Germany and America, but we have no means of being certain of this'. ${ }^{47}$

Whether conditions were the same in New Zealand or not, the private press served as a model for the Caxton Press in Christchurch, established in 1937 by Denis Glover and Leo Bensemann. (Its chosen name suggested an enterprise both new and intended to replicate a long-standing tradition: William Caxton was the first English printer, in the fifteenth century, and the first to print Chaucer's Canterbury Tales.) But already in Wellington Arts and Craft values had been absorbed, albeit less stringently, by John Beaglehole, a 'passionate autodidact of fine book typography and handcrafted design', in Sydney Shep's phrase. ${ }^{48}$ Beaglehole's skill and knowledge were honed first by exposure to books at home and in libraries, and then by seven years in London from 1926 to 1933. Once back in New Zealand, the opportunity presented itself to make books of his own, as typographical advisor to the Government's centennial publications programme. For the colonial, the ability to educate oneself was essential when attempting to reproduce, more or less singlehandedly, what Janet Paul called 'the best from Britain'. ${ }^{49}$

Although Beaglehole's interests were typographic rather than pictorial, he was a significant influence on John Pascoe, an aspiring photographer and writer who in I937 gratefully departed life as a law clerk in Christchurch to work on the centennial publications. By the early i950s Pascoe was illustrations editor in the Department of Internal Affairs' War Histories Branch, and he considered the relationship of type to illustration in a brief unpublished essay called 'Illustrate the Text'. The title seemed to conform to the English fine printing tradition, and he approvingly cited Bernard Newdigate, 'Scholar-Printer', contemporary of Gill and promoter of the work of Morris, whose 'ideal expressed in his The Art of the Book [was that] "illustration ... must be designed and worked in some degree of subordination to the rest of the book"'.50

46 Quoted in Harthan, The History of the Illustrated Book, no source given.

47 Eric Gill, An Essay on Typography (Jaffrey, New Hampshire: David R Godine Publisher, 1993), 2. 48 Sydney Shep, “"Touching the Mind of the Country”: JC Beaglehole and the Design of the Centennial Publications', Creating a National Spirit: Celebrating New Zealand's Centennial (Wellington: Victoria University Press, 2004), 195.

49 Janet Paul, notes from talks in Hamilton and Wanganui on the growth and problems of New Zealand publishing, I966, Janet Paul papers, Ms-papers-5640-I00, ATL, quoted in Shep, 'Touching the Mind', I94; Peter Lineham has pointed out the enduring strength of autodidacticism in New Zealand, at least until the universities began to grow rapidly in the i96os: Peter Lineham, interview, Radio New Zealand, I7 May 2012.

50 John Pascoe, 'Illustrate the Text', unpublished essay, Pascoe papers, Ms-papers-8I79-37, ATL. 


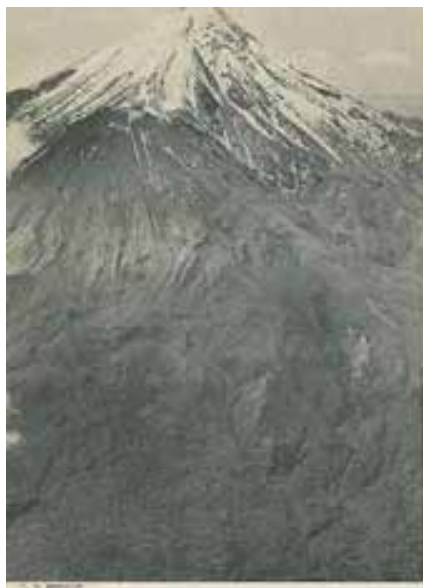

nim

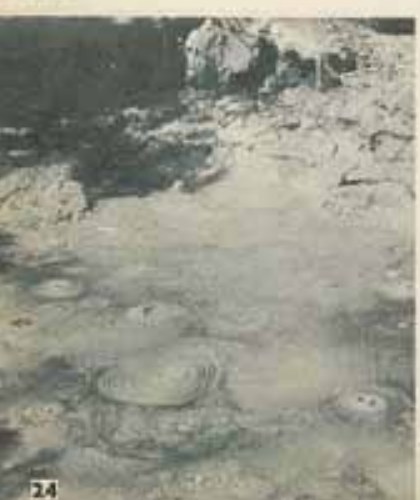

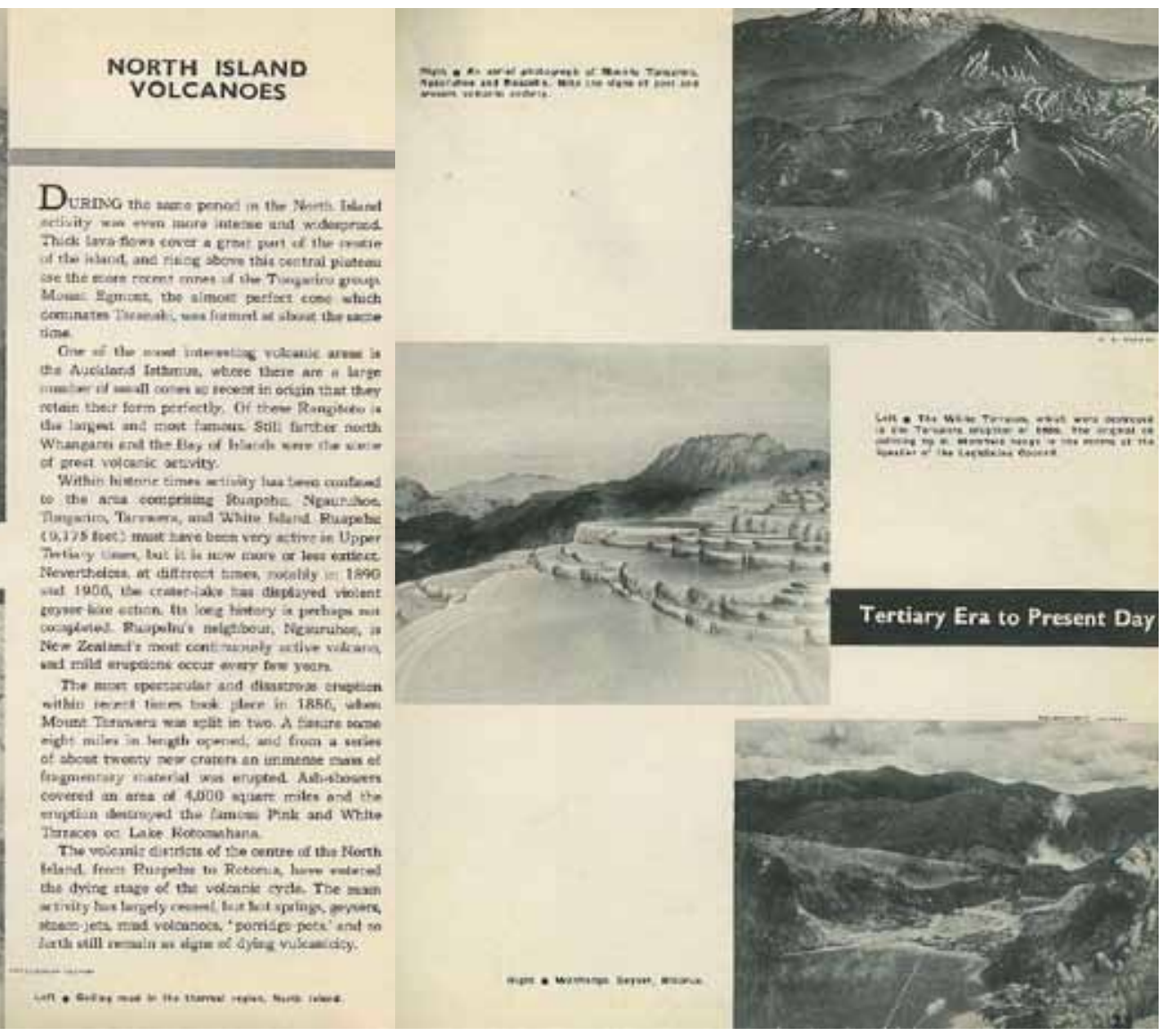

Spread from Making New Zealand 1:1 (1939), 24-25. http://nzetc.victoria.ac.nz/tm/scholarly/tei-Cen01-01Make-t1-body-d12.html.

On the face of it this essay seems to deny the evidence of Pascoe's work as illustrations editor for the centennial part-series Making New Zealand, where he first displayed a particular talent for making illustrations the primary focus of a publication. His boss there, Under-Secretary of Internal Affairs Joe Heenan, wrote: 'The pictorials are the outstanding work they are generally admitted to be principally on account of Mr Pascoe's genius for selection and layout of the illustrations. ${ }^{51}$ But the series followed an American rather than an English model. The Building America series, subtitled 'a photographic magazine of modern problems', combined text, photographs and graphic diagrams to create 'coherent educational materials that were substantively sound and carefully researched'. ${ }^{52}$

Making New Zealand comprised part works, not books, and the series was produced to be read by a mass audience. A further important distinction lies in the country of origin of the original. In matters of cultural reproduction London continued to set the standard, and Pascoe's I950s essay was primarily concerned with matters of reproductive quality as he pointed out the dangers of a 'transition

5I Under Secretary to Minister of Internal Affairs, 4 February I94I, Joseph Heenan papers, MS-papers-II32 fldr 296, ATL, quoted in Chris Maclean, John Pascoe (Nelson: Craig Potton Publishing, 2003), I26.

52 O L Davis Jr., 'Action as Part of Advocacy: Advancement of Progressive Education Practices by Professional Associations', American Education History Journal 32:I (2005), 5. 
from grace to crudity' by which artists' works became engravings or lithographs that were then 'pirated by lesser craftsmen, finally to emerge in the unkempt negligee of an over-heavily retouched photograph'. ${ }^{33}$ Decline in the standard of illustration brought a corresponding weakening of taste: 'The fashion of poorly reproduced photographs early in the twentieth century brought the whole down in a bottomless pit and the impact of mass production in printing added confusion in the darkness. ${ }^{54}$ If that sorry process seems to mirror colonial anxieties about the difficulty of ensuring the continuance of civilised life in the hinterland, I suggest that it is no accident.

\section{The Photobook}

The relatively limited scope allowed to the English illustrated book seems to have left ample terrain for the non-book to occupy. Notably, photographs were given little thought. Books of photographs, and indeed books that granted images equal or greater status to text, were a European, primarily German, innovation. In I95I, Whitcombe \& Tombs published Pascoe's The Mountains the Bush and the Sea, a collection of black and white photographs that were far from subordinate to their captions. That the traditional stance on illustration was starting to give way was suggested by one reviewer:

The function of illustrations had long been ill-defined, although it is many years since the camera brought this lavish illustration within the reach of all but the most modest publications. But photographs have remained, in general, like the artist's drawings whose place they inherited, very humble and submissive handmaids to the text. ${ }^{55}$

Pascoe's photographs were neither humble nor submissive. His book signalled 'something new, both in its conception of the purpose and possibilities of photographic reproduction, and in the presentation of the photograph'. Here was evidence that a photographer might be able to transcend the 'heterogenous quality of the art gallery or the scrap album' (or the non-book) and produce something that, if not art, had serious authorial intent. Of course, Making New Zealand had already demonstrated

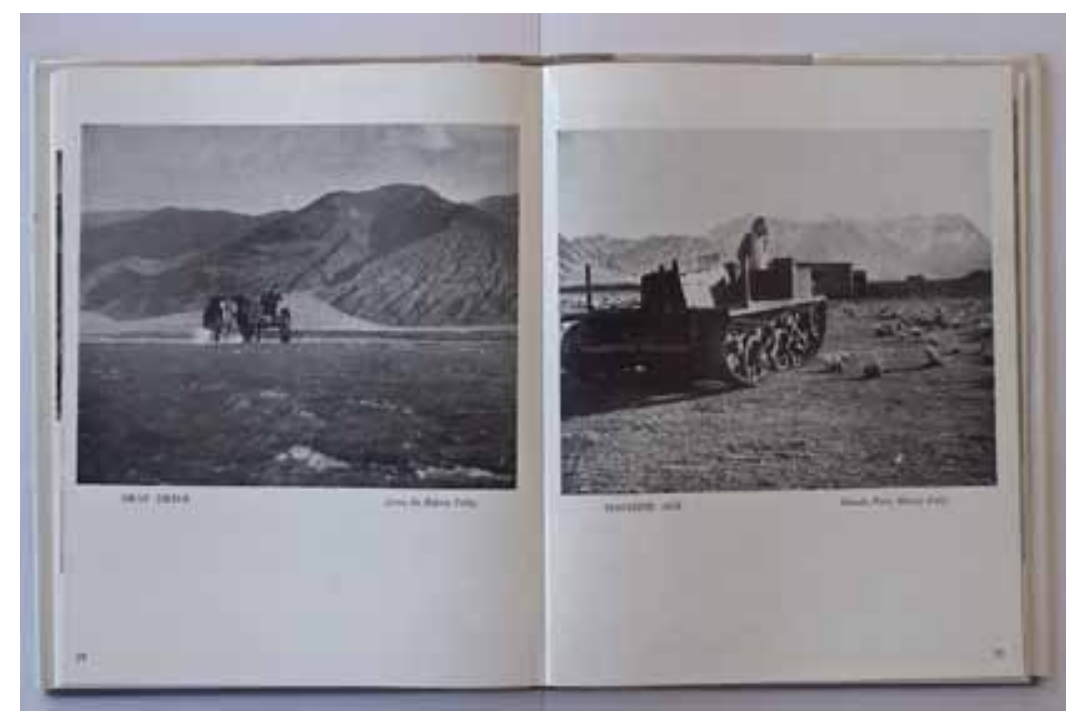

Spread from John Pascoe, The Mountains, the Bush and the Sea (Christchurch: Whitcombe \& Tombs, 1951).

53 Pascoe, 'Illustrate the Text'.

54 Ibid.

55 New Zealand Alpine Club, New Zealand Alpine Journal I4:38 (I95I), I29. 


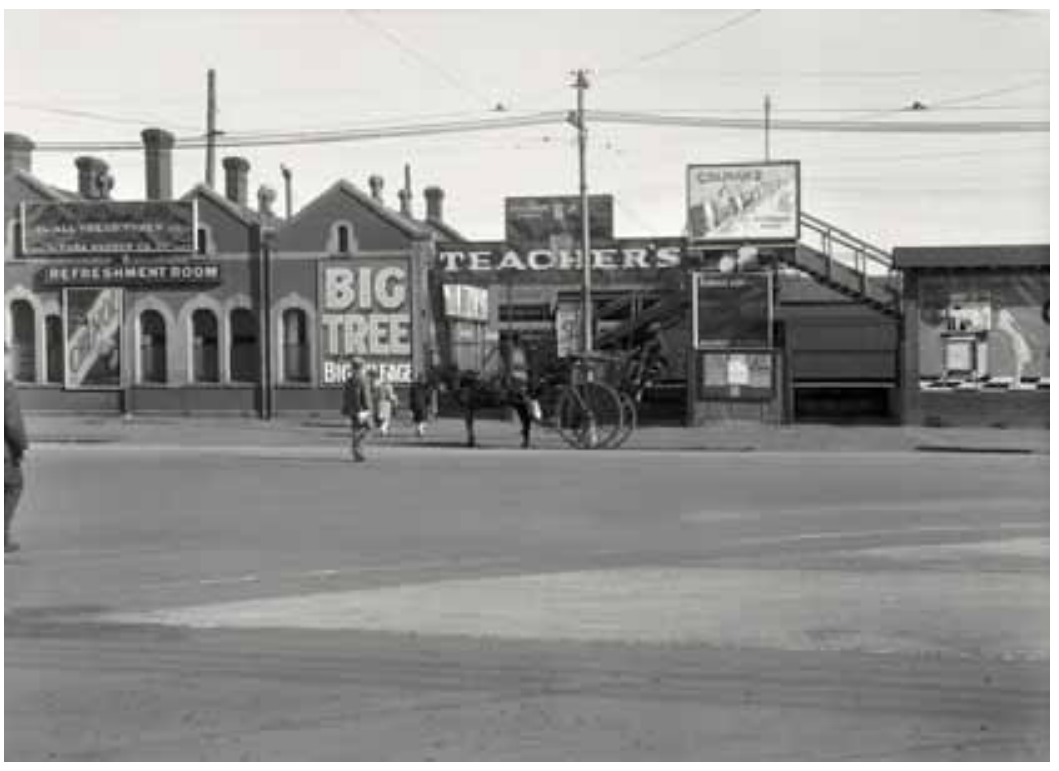

EO Hoppé, 'Cab hire outside Railway Station, Christchurch' (1930). www.eohoppe.com/newzealand.html.

this, in the curatorial sense that an illustrations editor's work suggests. Note too the reviewer's belief that photographs, in books, had inherited the role of artists' drawings. This is no doubt true: the development of printing technologies based on photographic processes had made it inevitable. But what was new about Pascoe's conception of purpose and presentation was adopted from European rather than English models.

During the interwar period Emil Otto Hoppé was, it has been said, the most famous photographer in the world, a claim based in part on the publication of books of his photographs. His Picturesque Great Britain (1926) was part of a series, originating in Germany, of books of photographs published mainly in Berlin and New York from the early I920s on as the Orbis Terrarum series..$^{56} \mathrm{~A}$ brief introduction summarised history and locality, and this was followed by descriptive captions facing each photograph. The images were printed as a single run, but captions were produced separately in different languages so that the whole could be combined by different publishers. ${ }^{57}$ In the I930s Hoppé travelled almost constantly: The Fifth Continent (193I) was the result of more than a year spent in Australia, and Round the World with a Camera appeared three years later. Hoppé visited New Zealand early in 1930 but seems not to have found the photographic (or perhaps commercial) potential to produce a book. ${ }^{58}$ While newspapers here acknowledged him as 'world famous' his books received few mentions. In 1936 the Auckland Star provided one reason for taking notice:

The colonial who visits London usually comes away with the knowledge that he has 'missed' a great deal that he would have wished to see; but if he looks through the pages of A Camera on Unknown London, by E O Hoppe, he will become aware that he 'missed' a great many things of which he has not even heard. 59

\footnotetext{
56 The New Zealand Libraries Catalogue shows one copy of Picturesque Great Britain in New Zealand, in the Massey University Library, and eight in the Orbis Terrarum series held in the Dunedin Public Library.

57 Mick Gidley, 'Emil Otto Hoppé, Autobiography, and Cultural Moments,' in The Photobook: From Talbot to Ruscha and Beyond (London: I B Tauris, 2012), 59; "Photobook" is the term now used to describe books that have the primary function of presenting photographs, usually the work of a single person. See also Martin Parr's exhaustive two-volume work The Photobook: A History (London: Phaidon, 2004). 58 See 'New Zealand', EO Hoppé Estate Collection, http://www.eohoppe.com/newzealand. html.

59 Auckland Star, 22 August 1936, 2.
} 


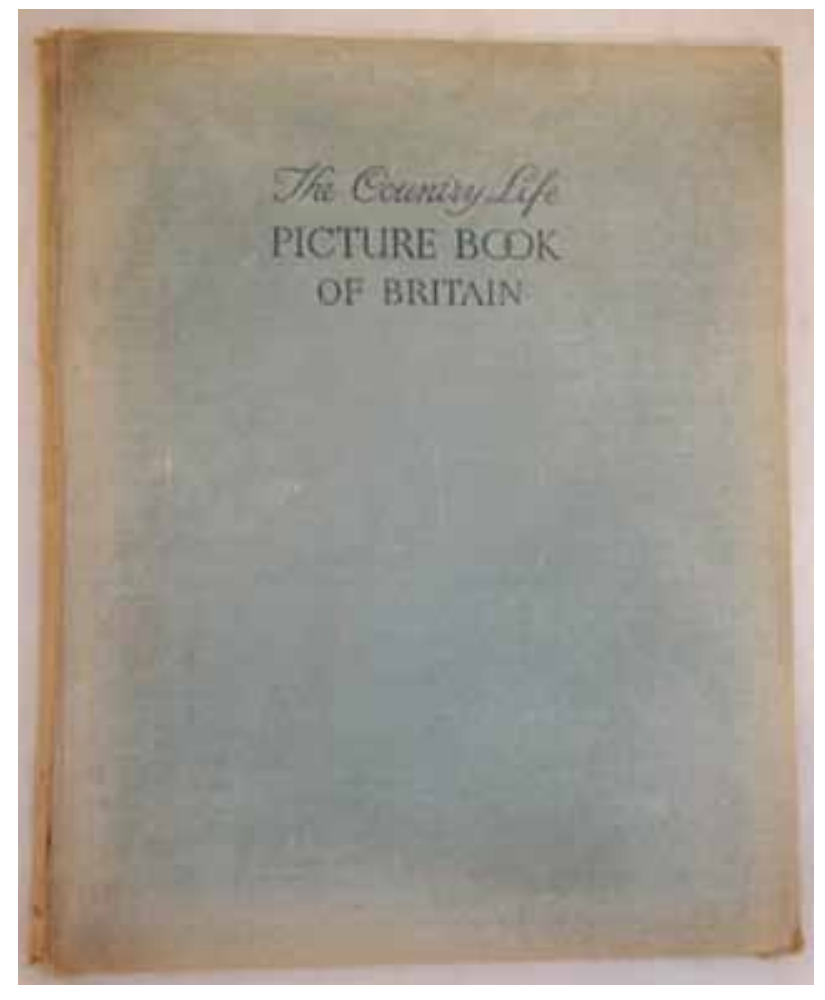

Cover and inside spread from The Country Life Picture Book of Britain (London: Country Life, 1937).

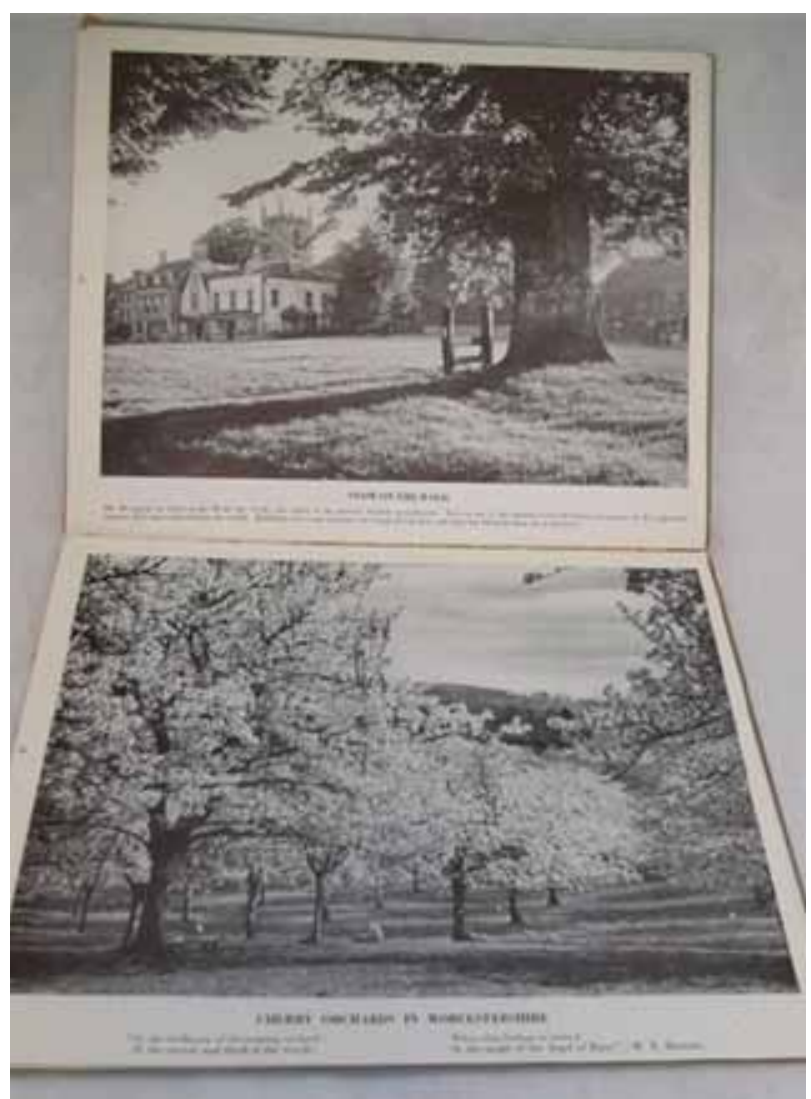

The New Zealand Libraries Catalogue shows i8 of his books (including some from a recent revival of interest in his work), mostly on London subjects.

In Britain the format was adopted by Country Life Publishing: The Country Life Picture Book of Britain (1937) began a series that continued at least until the mid I980s. Photographs of scenic Britain were the mainstay, but a second theme was royalty - such as the Country Life Picture Book of Princess Margaret's Wedding, 'specially and speedily prepared' after the 6 May 1960 occasion. ${ }^{60}$ These books became the actual model for New Zealand in Colour - even down to the text. Compare Raymond Birt's 'These pages are an invitation to explore, as it might be by celestial omnibus' with Baxter's 'This book invites you to make a journey.' ${ }^{3}$

60 The relationship between publishing and ideas about the countryside in Britain is usefully explored in relation to the firm of B T Batsford by Catherine Brace: 'Publishing and publishers: towards an historical geography of countryside writing, c 1930-1950', Area 33:3 (September 200I), 287-296. She notes that the firm specialised in 'in high-quality, lavishly illustrated, expensive, technical and scientific books and volumes on the decorative and creative arts' while cultivating an image of 'a group of scholar-craftsmen turning out expensive books for collectors and booklovers' (289-290). The apparent absence of scholarly interest in Country Life - either the firm, the magazine, or the books - is perhaps unsurprising but worth noting.

6I G F Allen, R Birt, and Country Life Ltd, The Second Country Life Picture Book of London (London: Country Life, I956), introduction; Bigwood and Baxter, New Zealand in Colour, introduction. 

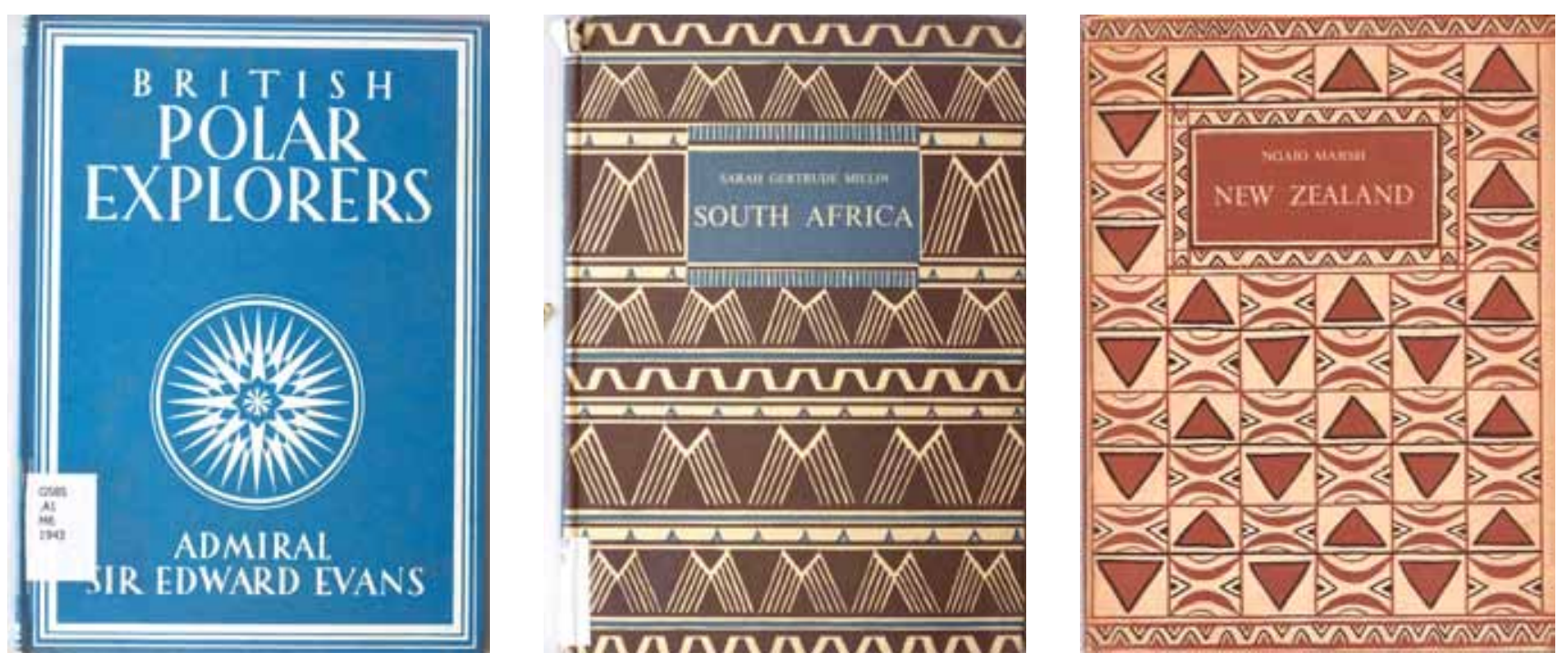

Titles from the Britain in Pictures series: British Polar Explorers by Admiral Sir Edward Evans, South Africa by Sarah Gertrude Millin, and and New Zealand by Ngaio Marsh.

The book that formed part of a series was another European influence. ${ }^{62}$ One of the first British examples, highly successful in its own right, was called Britain in Pictures, which began in 1939 and eventually comprised 132 titles. The idea came from former BBC head of news Hilda Matheson, specifically to counter wartime German illustrated books that promoted Germany and German culture and society. ${ }^{63}$ Nominally published by Collins, they were put together by a company called Adprint where production was managed by Walter Neurath, a Viennese Jew and refugee from Nazi Germany. Neurath went on to found Thames and Hudson in 1949, one of several expatriates from Germany and Austria, including André Deutsch, Paul Hamlyn and Robert Maxwell, who profoundly changed the character of English-language publishing in the postwar period. ${ }^{64}$ Neurath had already designed and produced the King Penguin series for Allen Lane, and 'had a genius for making illustrations an integral part of a book, placing them prominently on the page together with the words to which they were related, rather than banishing them to the plates section in the centre or (worse still) at the back of the book' ${ }^{65}$ Authors and artists who contributed to Britain in Pictures included George Orwell, Edith Sitwell, John Piper and Cecil Beaton. There was even a book in the series about New Zealand, written by Ngaio Marsh and RM Burdon, in which special acknowledgement was made of those who had allowed original images to be shipped

62 Tom Rosenthal, 'Walter and Eva Neurath: Their Books Married Words with Pictures,' in Richard Abel and William Gordon Graham, Immigrant Publishers: The Impact of Expatriate Publishers in Britain and America in the 20th Century (Transaction Publishers, 2009), II3. 63 Fred Hunter, 'Matheson, Hilda (I888-1940),' Oxford Dictionary of National Biography (Oxford University Press, 2004) online ed., May 20I2, http://www.oxforddnb.com/view/article/49198, accessed 28 April 2013.

64 Abel and Graham, Immigrant Publishers; Hobsbawm, Fractured Times, esp ch 7, 'The Jews and Germany'.

65 Rosenthal, 'Walter and Eva Neurath,' Immigrant Publishers, II3. 
to Britain to be reproduced. ${ }^{66}$ Authoritative and, at three shillings and sixpence, affordable, they suggested a successful future for mass-market books containing colour illustrations.

Allen Lane's Penguin paperbacks had already signalled before World War Two began that publishing in Britain was about to embark on a period of rapid change. But the propaganda and communication demands of the war accelerated this developement. Although the technology of process block, half tone and offset lithography had existed since the late nineteenth century, it was during the I940s that the opportunities it provided for the integration of text and image began to be fully exploited. ${ }^{67}$ The war effort required techniques of visual literacy to be deployed in Britain on a mass scale for the first time, through poster design, maps, diagrams and illustrations. New Zealanders' close links with Britain make it reasonable to suggest that their visual literacy was similarly affected by the war. The British Ministry of Information supplied posters and photographs for use in allied countries such as New Zealand, and their novelty and appeal is suggested by a report to New Zealand's Director of Publicity from men's outfitters Brown Ewing and Company:

They were splendid pictures and caused immense interest. It was remarkable how attractive they were to the people - who all day long - and during the evenings had their faces glued to the windows. ${ }^{68}$

Posters had another advantage over other media: colour. ${ }^{69}$

There is space here to suggest only an outline of changes stirring long-held habits of book production and reading in Britain (and spilling into New Zealand), a transformation that was precipitated by the development of mass culture capitalism and reinforced by the effects of war. But it should be clear that the function of illustrations in books was near the centre of the change.

66 Ngaio Marsh, New Zealand, Britain in Pictures (London: Collins, 1942), The copyright page notes that the book was produced by Adprint and printed by Harrison \& Sons Ltd (printers to His Majesty the King).

67 Paul Rennie, 'Socialvision: visual culture and social democracy in Britain during World War II', Journal of War and Culture Studies I:3 (2008), 243-259; Rennie, 'British Picture Books for Grown-ups from the I940s', pdf, September 2005, http://www.rennart.co.uk/website.pdfs/books.pdf; Allen Lane launched Puffins at $6 \mathrm{~d}$ each in 1940, replicating a 'revolution in the design and illustration of children's books' that originated in the UsSR. Artists worked directly onto lithographic plates to cut production costs: James Russell, 'Puffins on the Plate', Eye 22:85 (2013), 62-7I.

68 Manager to Director of Publicity, I September I94I, EA I, 84/12/I2, pt 2, ANZ, quoted in Stephanie Gibson, 'Display folk: Second World War posters at the Museum of New Zealand Te Papa Tongarewa,' Tuhinga ig (2008), I2.

69 Gibson, 'Display folk,' 8. Although Gibson concentrates on New Zealand-produced posters, she acknowledges that 'the New Zealand Government produced few posters of its own ... partly owing to the constant stream of posters sent from Britain': ibid, I4. 


\section{The unkempt negligee of an over-heavily retouched photograph}

In the early I950s, seeking to explain higher standards of New Zealand book illustration from the late i930s on, Pascoe advanced a standard cultural nationalist argument: 'the attitude of the artist in books about New Zealand was reflected in pastures and forests insipidly anglicised into sentimental recollections of homeland, rather than of a clear perception of the beauties of the new country'..$^{\circ}$ The suggestion that it had required strong-minded men to see New Zealand clearly for the first time is reinforced by Chris Hilliard's description of how, during the ro3os and I940s, a New Zealand literary canon came to be defined in masculine terms in part through a claim that 'those whose British inheritance is not sufficiently tempered by colonial life tend to be women, and their failings are implicitly feminine failings'. ${ }^{71}$ In his history of Reeds, Edmund Bohan suggests that 'radical changes in reading habits and public tastes' after World War Two were 'driven by the return of thousands of servicemen and women'.$^{72}$ I have argued here that, at least where illustrated books are concerned, the process of change was more complex and more closely linked with changes occurring in British publishing than either Pascoe or Bohan acknowledge. Ray Richards returned from the war to rejoin Reeds as production manager in 1946, and by the 1960 s had become managing editor. After finishing his war service he had worked briefly in publishing in Britain, and he retained a keen interest in current trends in Britain (and also North America) as a regular reader of the London Bookseller and New York Publishers Weekly. ${ }^{73} \mathrm{He}$ was not alone: requests from New Zealand booksellers were significant in Reeds' decision to embark on its In Colour series, and the long-running success of the Country Life books no doubt prompted this local enthusiasm and confirmed the good sense of directly copying a British model. But bookshop browsers in I96I might well have been struck by differences as well as similarities. Country Life's celebration of Princess Margaret's nuptials was in black and white. While the first edition of New Zealand in Colour was by no means perfect, a comparison with the first Country Life colour book, Britain in Colour, which appeared in 1957, would have made it immediately obvious that the British product by no means bettered the quality of printing and reproduction that Reeds' book achieved. The colours of the British book were less vivid, the images less sharp, the printing sometimes blurred, and the paper was obviously a cheaper stock. It is a small but significant point (especially as it occurred at the moment that Britain seemed about to cast New Zealand adrift economically by joining the European Economic Community) that a local firm was able to outdo the English model in terms of quality of reproduction.

If the original was not visible, because it was 12,000 miles distant, accurate reproduction became essential for greater reasons than merely technical ones. I

\footnotetext{
70 Pascoe, 'Illustrate the Text'.

7I Chris Hilliard, The Bookmen's Dominion: Cultural Life in New Zealand 1920-1950 (Auckland:

Auckland University Press, 2006), I02.

72 Edmund Bohan, The House of Reed 1907-1983: Great Days in New Zealand Publishing (Christ-

church: Canterbury University Press, 2005), 75.

73 Ray Richards, email to author, 5 November 2012.
} 

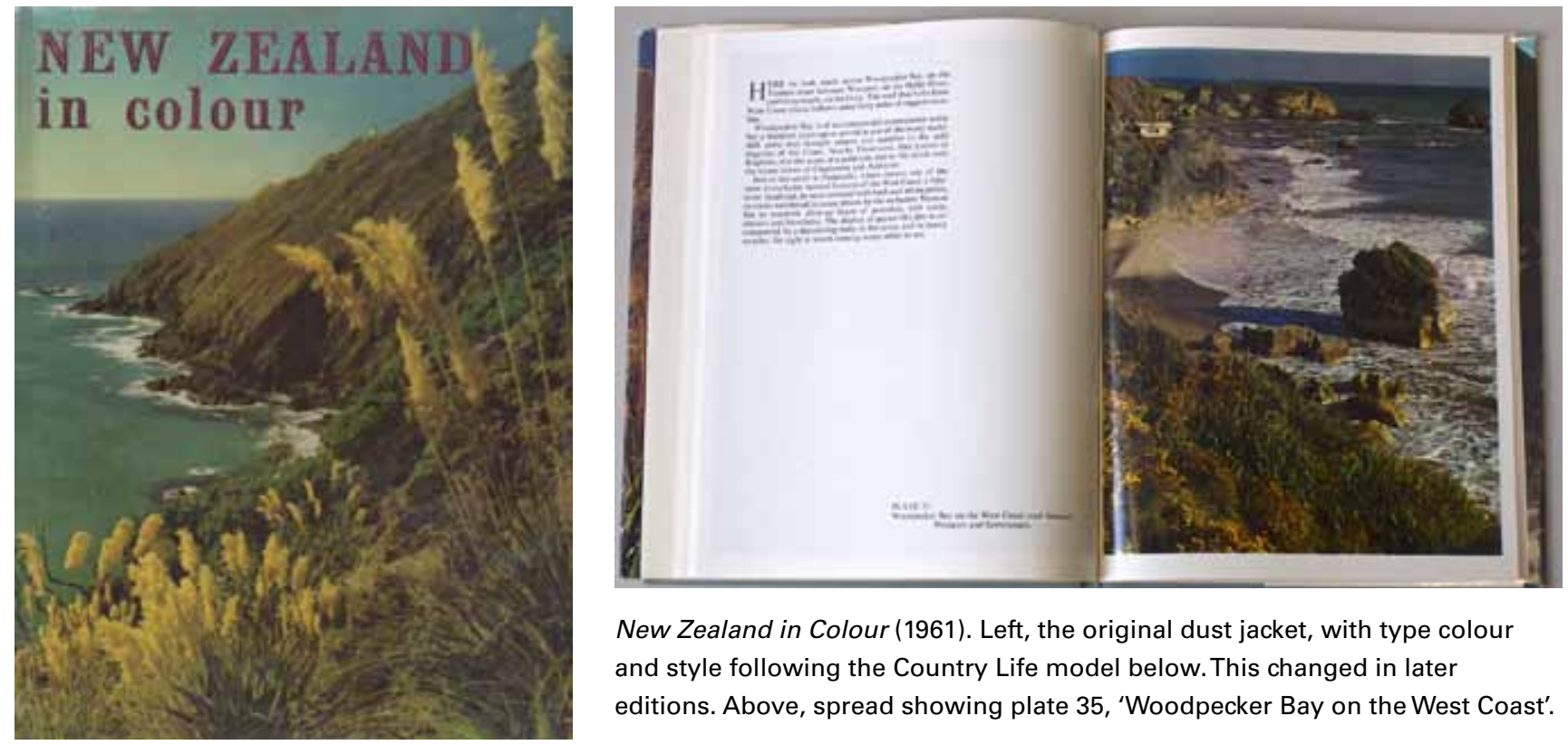

New Zealand in Colour (1961). Left, the original dust jacket, with type colour and style following the Country Life model below. This changed in later editions. Above, spread showing plate 35, 'Woodpecker Bay on the West Coast'.

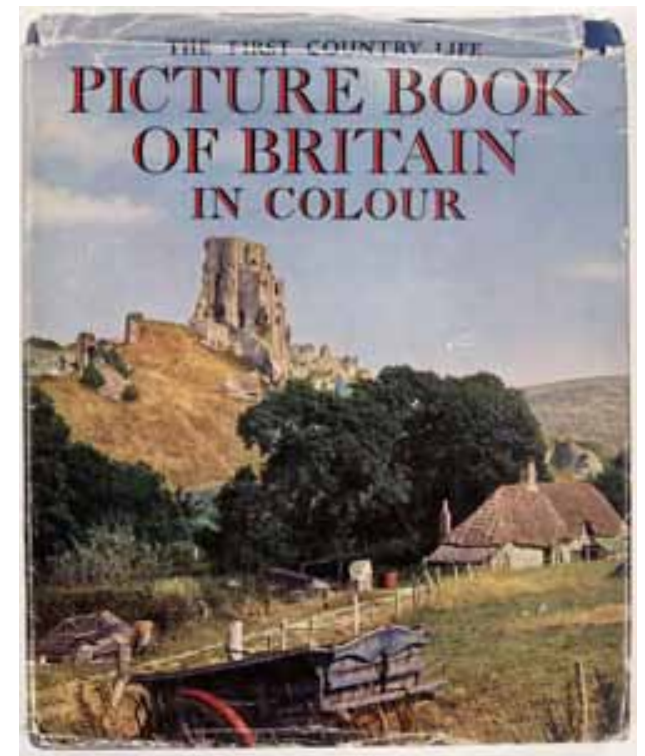

The First Country Life Picture Book of Britain in Colour (1957). Clockwise from left: cover; reference map; spread showing plate 9, 'St Mawes, Cornwall'; detail of plate 9 showing printing defects.
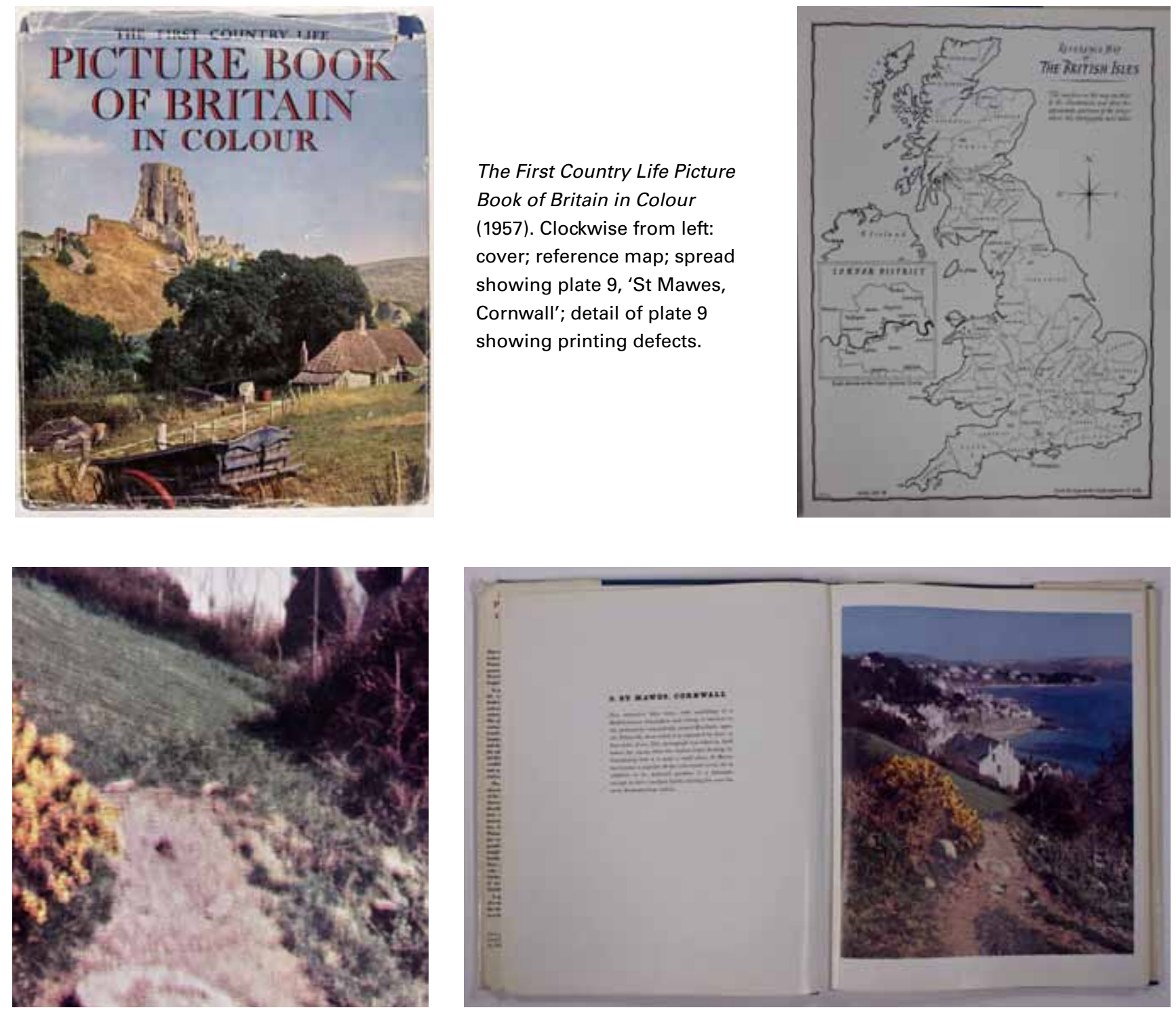

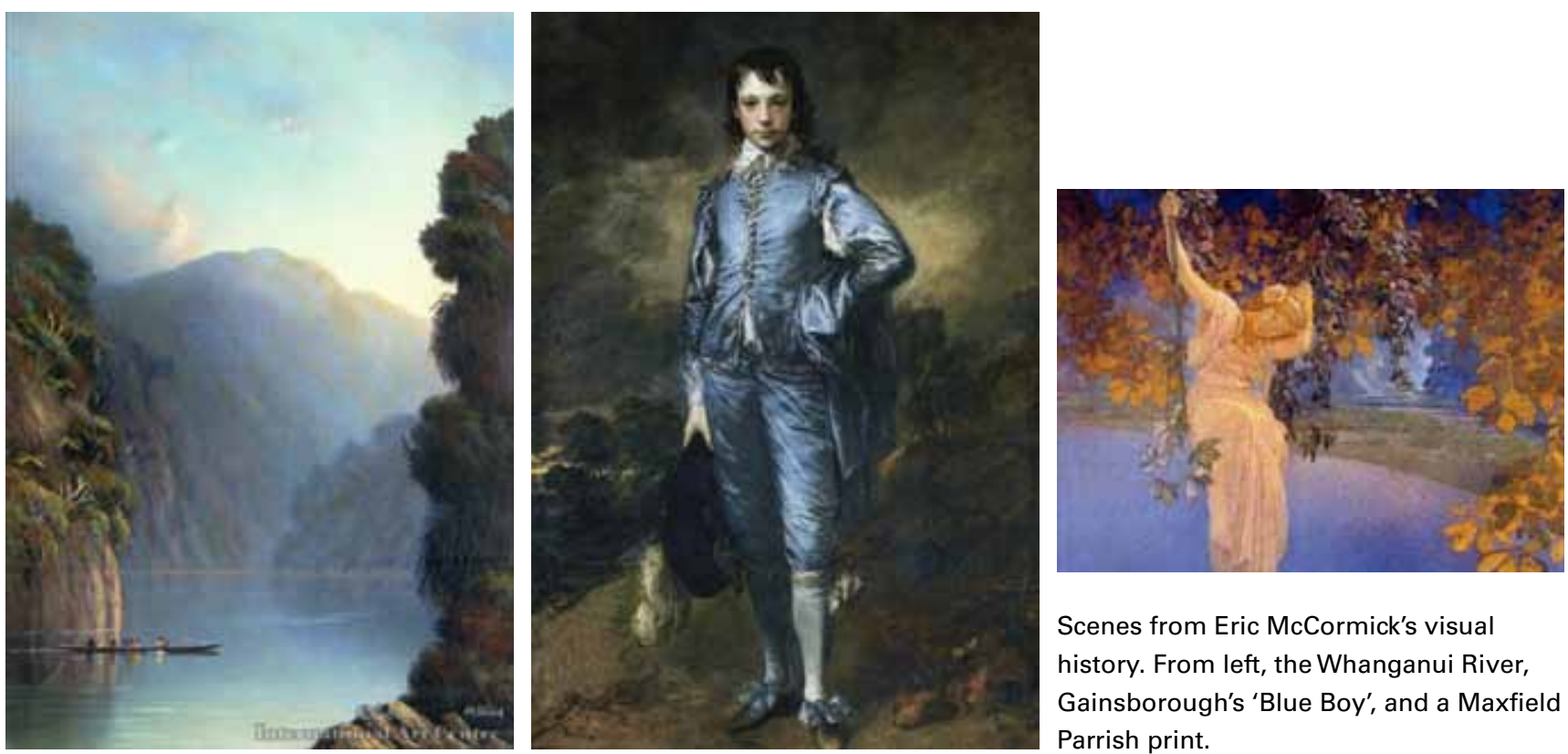

Scenes from Eric McCormick's visual history. From left, the Whanganui River, Gainsborough's 'Blue Boy', and a Maxfield Parrish print.

suggested at the outset of this chapter that the problem of reproduction became especially acute in societies that existed on the periphery of their culture. In I957, the historian Eric McCormick addressed the Auckland Gallery Associates on what he called his 'visual history'. The lecture was published two years later as The Inland Eye, with a striking cover design by gallery 'keeper' Colin McCahon. As a child in Taihape, McCormick remembered, 'Our art, like everything else except timber and basic food-stuffs, was imported from outside.' It was 'an art of the printing press'. And when in 193I, aged 25, he sailed to London for the first time, 'I had never seen a really good painting, except in reproduction'.$^{74}$ Although reproduction was intrinsic to the colonial society, this characteristic remained largely unrecognised due to an overriding preoccupation with discovering the means to differentiate itself from the centre. McCormick claimed to have concocted the theory, when he worked on the government's centennial publications, that as Pakeha adapted to their surroundings this would eventually lead to an awareness of cultural specificity and community. By 1957 he seemed less sure of himself, remembering how 'by devious reasoning from somewhat platitudinous premises I had found my way to the uneasy refuge of nationalism'.75 If we re-position the adaptive work of the cultural nationalists within a larger proposal that cultural evolution be 'grasped as a symptom of the dynamics of an international capitalist system', it becomes pos-

\footnotetext{
74 EH McCormick, The Inland Eye: A Sketch in Visual Autobiography (Auckland: Auckland Gallery Associates, I959), II, 27.

$75 \mathrm{Ibid}, 4 \mathrm{O}-4 \mathrm{I}$. The idea nevertheless put down roots and has survived to this day. As recently as 20II, in its report on 'Maori culture and identity' the Waitangi Tribunal wrote that: 'Cook's people ... succumbed to the whenua's slow seduction just as surely as Kupe's people had. The transplanted British institutions and ideas took root in the soil, but the soil changed them.' (Waitangi Tribunal, Ko Aotearoa Tenei: A Report into Claims Concerning New Zealand Law and Policy Affecting Maori Culture and Identity. Te Taumata Tuatahi (Wellington: Legislation Direct, 20II), I2.
} 
sible to see that it was no longer simply a matter of settling in and making an accommodation with the environment. ${ }^{76}$ Peter Gibbons writes that Pakeha " knew" about Mt Cook . . . and other scenic wonders without ever visiting these often outof-the-way places, simply through repeated reproductions of images that became iconic'. ${ }^{77}$ But pastel landscapes of the Whanganui River shared space on the walls of McCormick's parents' home with reproductions of paintings of highland cattle, Gainsborough's 'The Blue Boy' and 'the idylls of Maxfield Parrish'.78 Cultural colonisation proceeded not only through displacement and then appropriation of the indigenous; equally important were processes of importation, acclimatisation and repeated reproductions of icons of cultural authority from "Home". Indeed, reproduction itself became a project of manufacturing a culture that could match, to some acceptable degree, the authority, requirements and achievements of the metropolitan home (in this case, London), yet co-exist satisfactorily as a discrete, fully functioning system.

The difficulties inherent in the ambition to attain a level of comparability as a qualitative measurement might be usefully rephrased as questions of definition. Quality, therefore, became a matter of careful and faithful reproduction. Pascoe's 'unkempt negligee of an over-heavily retouched photograph' - surely as much moral as cultural hazard - seems to have posed a threat to the society he lived in that was far more dire than simply not being able to see the picture clearly. At this great distance from the metropolis where they could no longer adequately view the original, he seems to have been asking, how could New Zealanders know that they were sufficiently and appropriately civilised if not by being able to rely on the fidelity of the copies that reached them and that they themselves had created? In his account of colonial urban development, David Hamer wrote that ambivalence often underlay pride: 'they had built towns which were comparable to those of the Old World or the East or the "mother country", which were acceptable replicas of an urban civilisation developed elsewhere'. ${ }^{79}$ He quotes a visitor to Melbourne in 1886 describing it as a 'reproduction of a British metropolis' ${ }^{80}$ Perhaps ambivalence is a more suitable tone than pride for historians to adopt. It is implicit in what I identified at the outset as a relationship between provincial fact and international validity and which can now be identified by name both as "nation" and as New Zealand, whether in colour or a gift of the sea.

It is also a deeply conservative rhetoric, but that is a further reason to take it seriously: as a possible frame within which to discuss cultural conservatism in New Zealand. Discussing cultural authority 'embodied and exercised', the American historian Michael Kammen points to Matthew Arnold's association of 'the designation and legitimization of culture with social authority, that is, the well-established

76 Fredric Jameson, A Singular Modernity: Essay on the Ontology of the Present (London ; New York: Verso, 2002), XX.

77 Peter Gibbons, 'Cultural Colonization and National Identity,' NZJH, Io.

78 McCormick, The Inland Eye, II.

79 David Hamer, New Towns in the New World (New York: Columbia University Press, 1990), 225.

80 WJ Woods, A Visit to Victoria (London: I886), I3, quoted in ibid, 226. 
social order and its institutions', and points to the problem, in late-nineteenth century America, of reconciling the Arnoldian ideal of 'the best that has been thought or said' with the levelling of authority known and celebrated as democracy. ${ }^{8 \mathrm{I}} \mathrm{How}$ this may have played out in New Zealand is beyond my scope. That similar tensions were present and perhaps even more acute seems likely. In this chapter I began my account of the illustrated book in the I840s partly to test Peter Gibbons's idea that the processes of cultural colonisation have been a constant of the New Zealand past 'since Europeans first appeared over the horizon'. ${ }^{82}$ A second reason is that it seemed necessary to locate a similarly lengthy period of influence for the role of reproduction in that process. Clif Reed's story that the company's directors had become involved in the Evening Post's decision to return a hardbound, Japaneseprinted collection of photographs of New Zealand that was not a book may or may not have been true. But it was astute. The ninety-eight-year-old family-owned company was part of what Felicity Barnes calls the 'imperially-engaged elite' of 'newspaper editors . . and Governors-General'. ${ }^{83}$ The chairman of the directors was Henry Blundell, whose son, as Sir Denis, became in 1972 the first New Zealand resident to be appointed as Governor-General. ${ }^{84}$ In 1963, when the Evening Post sent a bemused young messenger down Mercer Street, it was not the pin-sharp quality of the images, nor the accuracy of their colour that was at issue. Rather, the nonbook was defined by the degree to which it deviated from the forms prescribed by an educated elite still trained to preserve and celebrate the achievements of art and empire that had reached their zenith at the end of the nineteenth century. London's influence on Reeds was still powerful, but it is better understood through Barnes's model of the metropolis and the hinterland (or province). But prescription was one thing; popularity quite another. The next chapter will look for reasons why, despite its questionable heritage, the non-book succeeded so spectacularly.

8I Michael G Kammen, American Culture, American Tastes: Social Change and the 2oth Century, (New York: Knopf, 1999), ch 6.

82 Gibbons, 'Cultural Colonization and National Identity,' NZJH, 7.

83 Barnes, 'New Zealand's London', 20-2I, 280.

84 Gavin McLean, The Governors: New Zealand's Governors and Governors-General (Dunedin: Otago

University Press, 2006), 29I-297. 


\section{Participating in Modernity: Leisure, Mobility, and Consumption}

\section{Introduction}

When New Zealand in Colour appeared in late 196I it was an immediate sales success. By June the following year, Reeds publisher Ray Richards could tell booksellers that a second printing had been 'heavily oversold' and a third was on order: 'every new delivery of stock is sold before it reaches New Zealand'. In July 1962, Richards announced arrangements to publish the book in four other countries, which he thought 'must be a unique achievement for a New Zealand book'. ${ }^{2}$ His August newsletter boasted of an initial print run of 40,000 copies for New Zealand in Colour Volume Two, which 'must be one of the largest ever for a New Zealand book and a complete sell-out can already be predicted'. ${ }^{3}$ But the colour pictorials the non-books, as we have seen - were at the forefront, prompting a separate set of questions. What can the colour pictorials tell us about what New Zealand looked like to Pakeha in the early I96os? Why were illustrated books suited to this task? Can the non-book be identified with a community of non-readers and, if so, what were its characteristics?

This chapter addresses three aspects of the world reproduced in the colour books. First, the books' relationship to tourism and the tourist market needs to be clarified. Although Pakeha acknowledged the importance of the tourist, it was not a straightforward relationship. This was reflected in the way that the deluxe cosmopolitan form of the book-as-object contained on its pages a celebration of the anti-tourist who could 'find one's own camping ground in one of the secluded places'. ${ }^{4}$ The importance of tourists to understanding what New Zealand looked like to Pakeha, I argue, lay in a shared consumption of scenery: this kind of looking

\footnotetext{
I Ray Richards, 'From the Editor’s Desk at Reeds' [May/June 1962], John Pascoe papers, MS-papers-8I79-30, ATL.

2 Ray Richards, 'From the Editor's Desk at Reeds', July 1962, John Pascoe papers, MS-papers-8I79-30, ATL. 3 Ray Richards, 'From the Editor's Desk at Reeds', August 1962, John Pascoe papers, MS-papers-8179-30, ATL.

4 Kenneth Bigwood and James K Baxter, New Zealand in Colour (Wellington: A H \& A W Reed, I96I), pli3.
} 
at New Zealand was an important way for Pakeha to participate in 'First World' modernity.

Secondly, to explain why the photographic essay proved so well suited to books about New Zealand, the argument draws on Blake Stimson's recent analysis of The Family of Man photographic exhibition and book. Dubbed the 'greatest photographic exhibition of all time' by its promoters, the exhibition dominated Western photography in the late I950s and early I960s. For Stimson, it marked a historically specific moment between nationalist-fuelled traumas of war and the oncoming tide of consumerism, in which the photographic essay enabled viewers 'to experience objectivity as a universal identification, to experience the objectivity of "photography itself" as one experiences nation'. This was what the colour pictorials offered, whether overtly influenced by The Family of Man like Brian Brake and Maurice Shadbolt's New Zealand: Gift of the Sea or not. New Zealand was experienced by turning the page, via 'the beauty of truth', ${ }^{6}$ as photography itself.

The final and longest section might be framed by British art critic John Berger's 1955 remark that 'a great deal of highbrow and lowbrow culture derive from exactly the same attitude of life and differ only in their degree of self-consciousness' ? The Reeds hewed carefully and self-consciously to a middlebrow ideal, distrusting expert or academic opinion on one side and adopting a morally conservative, antipopulist stance on the other. ${ }^{8}$ Distinctions between brow heights were born of latenineteenth century phrenological ideas about cranial capacity but quickly passed into common use, and the finer points of classification were avidly discussed by Clif Reed and his uncle. There were 'difficult decisions to make as to what constitutes an ultra-low-brow record,' Clif puzzled in $1959 .{ }^{9}$ While the ability to steer down the middle of the road contributed to the colour pictorials' success, the question of taste has somewhat obscured subsequent assessments. Like The Family of Man, the colour pictorials - and especially the Bigwoods' work - have become 'a whipping boy for middlebrow midcentury aesthetics' ${ }^{\prime \prime}$ Peter Ireland recently suggested that the difference between Bigwood and Brake is 'the difference between a Chesterfield suite and a Bauhaus chair'. ${ }^{\text {II }}$

This study shifts attention away from the literary or aesthetic qualities of the authors' and photographers' work, in favour of uncovering the attitude of life that is on display. There is no question that Brake's photographs, in their range,

\footnotetext{
5 Blake Stimson, The Pivot of the World: Photography and Its Nation (Cambridge, Mass: MIT Press, 2006); Edward Steichen, The Family of Man (New York: Museum of Modern Art, 1955).

6 Brian Brake and Maurice Shadbolt, New Zealand: Gift of the Sea (Christchurch: Whitcombe and Tombs, 1963), dust jacket.

7 John Berger, 'The Cultural Snob: There is No "Highbrow Art"', The Nation, 5 November 1955 , 380-382, quoted in Michael Kammen, American Culture, American Tastes: Social Change and the 2oth Century, (New York: Knopf, 1999), i3.

8 Gavin McLean, Whare Raupo: The Reed Books Story (Auckland: Reed, 2007), 76-77, 99.

9 A W Reed to A H Reed, 29 October 1959, Reed correspondence 1957-1963, 75-053-4, ATL.

Io The phrase is from Fred Turner, 'The Family of Man and the Politics of Attention in Cold War America', Public Culture 24:I (2012), 55.

II Peter Ireland, 'Looking at New Zealand', Brian Brake: Lens on the World (Wellington: Te Papa Press, 2010), 252.
} 
sensitivity, drama, and intimacy, demonstrate greater artistic ambition and achievement than the Bigwoods' work. Promoting the book in 1963, publisher Whitcombe $\&$ Tombs claimed Gift of the Sea had 'that rare arresting magic quality of genius which distinguishes a work of art'. ${ }^{2}$ David Eggleton in 2006 called it 'symphonic': Brake's camera 'sculpts the very grain and shape of a face'. ${ }^{13}$ Yet in a concluding footnote to his account of the publication and reception of Gift of the Sea, Ireland writes that the book's value is as 'a potently caught moment in time'. ${ }^{14}$ That kind of utility, I suggest, will be enhanced by taking an interest in what the colour pictorials have in common. In seeking to situate the books historically, my approach is informed by Robin Kelsey's observation that some recent scholarship on photography has 'taken a keen interest in how photographs and their circulation establish social ties, negotiate commonalities and differences of identity, confirm cultural assumptions, and generate moral obligations'. ${ }^{15}$ This attentiveness to reception and consumption is also characteristic of recent work in book history and print culture, spanning Roger Chartier's communities of readers and Benedict Anderson's imagined communities of print capitalism. And if Stimson's work is a useful demonstration that photography performs this sort of work rather differently than writing, it is also a reminder that reading was just one of many things done with the colour pictorials. James K Baxter suggested they were made to be thumbed through, and that there was a pattern to be explored for those who cared to embark on the journey. John Pascoe wrote: 'Let no more be said; it is for you to browse, to reflect, and to consider.' ${ }^{\prime} 6$

Considered as a genre, the colour pictorials mythologised the 'beauty of truth' as the reward of seeing New Zealand 'as she actually is' ${ }^{17}$ They depicted an attitude of life shaped by the leisure practices of suburban, mobile, middle class men (mostly) who remained largely outside the frame behind their viewfinders and steering wheels. The colour pictorials acheived universal identification through photography, but also through driving and the holiday, and in so doing brought place - New Zealand - into balance with modernity. In her contribution to the New Oxford History of New Zealand titled 'Modernity, Consumption and Leisure', Caroline Daley argues that there is more of interest in the wider world's place in New Zealanders' free time than in the few, unique activities that New Zealand can claim as its own', and that cultural nationalism and 'attempts at biculturalism'

\footnotetext{
I2 Whitcombe $\&$ Tombs publicity flyer, 1963, Te Papa Archive ca 828/2/4, quoted in Ireland, 'Looking at New Zealand', Brian Brake, 255.

I3 David Eggleton, Into the Light: A History of New Zealand Photography (Nelson: Craig Potton, 2006), 106.

I4 Ireland, 'Looking at New Zealand', Brian Brake, 315, n35.

I5 Robin Kelsey, 'Our Lady of Perpetual Help: Thoughts on Recent Photographic Scholarship', Aperture, 2Io (Spring 2013), 54.

I6 Bigwood and Baxter, New Zealand in Colour, introduction; Kenneth Bigwood and John Pascoe, New Zealand in Colour, Volume Two (Wellington: A H \& A W Reed, 1962), introduction.

I7 Bigwood and Baxter, New Zealand in Colour, introduction.
} 
cannot sufficiently explain leisure and consumption. ${ }^{8}$ Yet the pictorial books demonstrate how deeply implicated Pakeha New Zealanders' free time became in their conception and experience of nation. Rather than nation and nationalism being explanatory tools for assessing the significance of leisure and consumption, the reverse may be true.

\section{The moral tourist}

These unshaped islands, on the sawyer's bench,

Wait for the chisel of the mind ${ }^{19}$

On finding some lines by James K Baxter in Kenneth Bigwood and Monte Holcroft's New Zealand, Gavin Hipkins experiences a 'horrible irony' that this poem 'is found to grace the inside of this coffee-table book' ${ }^{20} \mathrm{~A}$ further irony (if that is what is sought) might be found in an early draft in one of Baxter's poetry notebooks, probably written around the time the poet was working on his text for New Zealand in Colour during the summer of 1960-6r:

These unshaped islands wait for us

As if on a child's humorous map

With Abel Tasman drinking schnapps

Waiting for us to hack the clouds away ${ }^{21}$

A 'fun map' of New Zealand commissioned by Clif Reed in 1939 had led to perhaps the most serious falling-out between the Reeds, when A H threatened to withdraw his name from the company. ${ }^{22}$ Had that story reached Baxter, perhaps as part of a pre-emptive effort to stave off potential problems that might creep into the poet's captions? By 1960, however, production of such maps had shifted from publishing firms to breweries (see images, right).

While he may privately have seen humour in the assignment to caption the Bigwoods' images, there is nothing to suggest that Baxter was especially troubled by the project. His biographer Frank McKay recorded that Baxter could do in a day what would take another person a week, do it better, and did not care what happened to it after. ${ }^{23} \mathrm{He}$ was putting on suit and tie each weekday morning in suburban Ngaio and 'riding the gravy train', as his colleague Alastair Campbell put

I8 Caroline Daley, 'Modernity, Consumption and Leisure', in Giselle Byrnes, ed, The New Oxford History of New Zealand (Melbourne: Oxford University Press, 2009), 445.

I9 James K Baxter, 'New Zealand', in Kenneth Bigwood and Monte Holcroft, New Zealand (Wellington: AH\& A W Reed, 1963), 7.

20 Gavin Hipkins, 'Dreamers that Struggle to Wake', in Lawrence McDonald, ed., Handboek: Ans Westra Photographs (Wellington: BWX, 2004), 66.

2I 'New Zealand', Book xxI, c 1960-196I, James K Baxter literary papers, MS-0704/02I, Hocken.

22 McLean, Whare Raupo, 58-60.

23 Gregory O'Brien, A Nest of Singing Birds: 100 Years of the New Zealand School Journal (Wellington: Learning Media, 2007), 57; Frank McKay, The Life of James K. Baxter (Auckland: Oxford University Press, 1990), I90. 


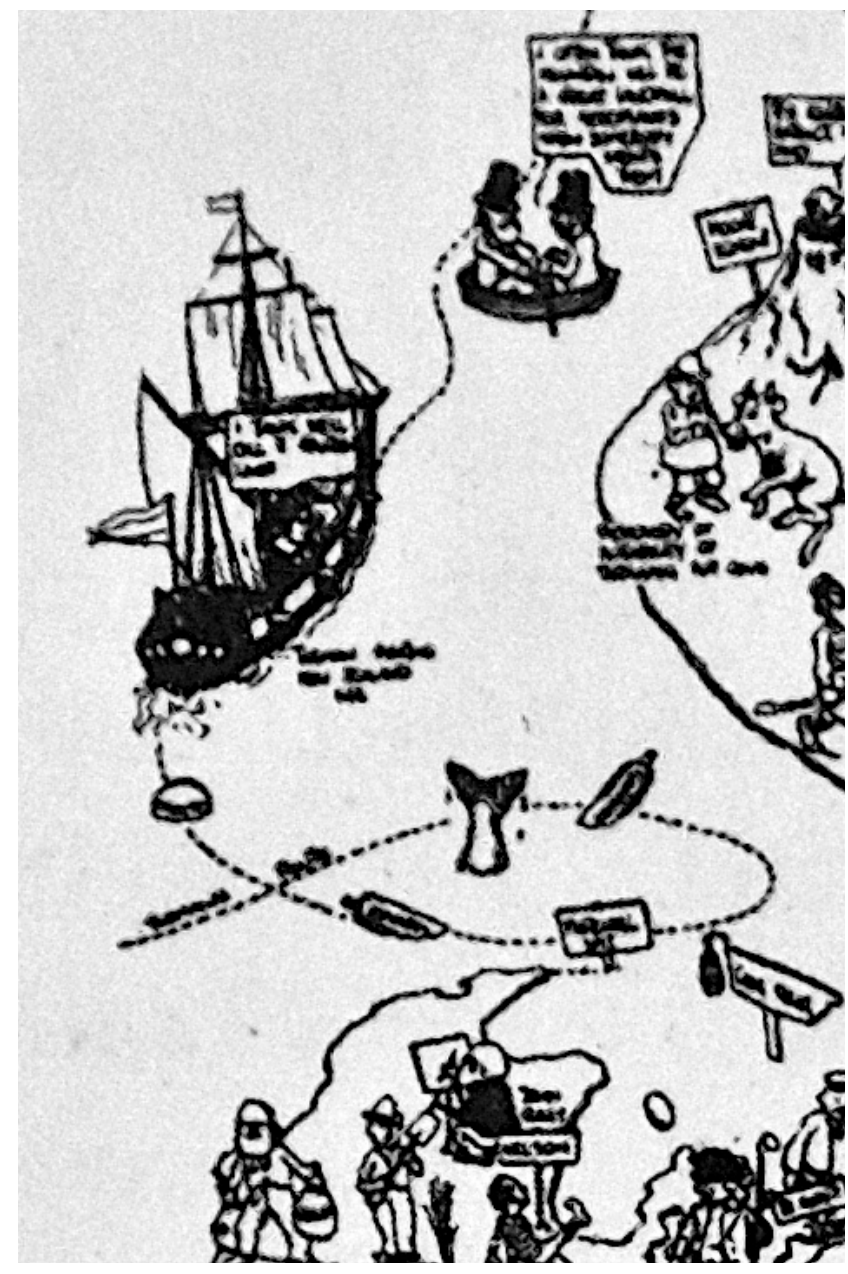

Detail from flyer for the 1939 Historical Fun Map of New Zealand that $\mathrm{AH}$ Reed took exception to. Reproduced from McLean, Whare Raupo, 59.

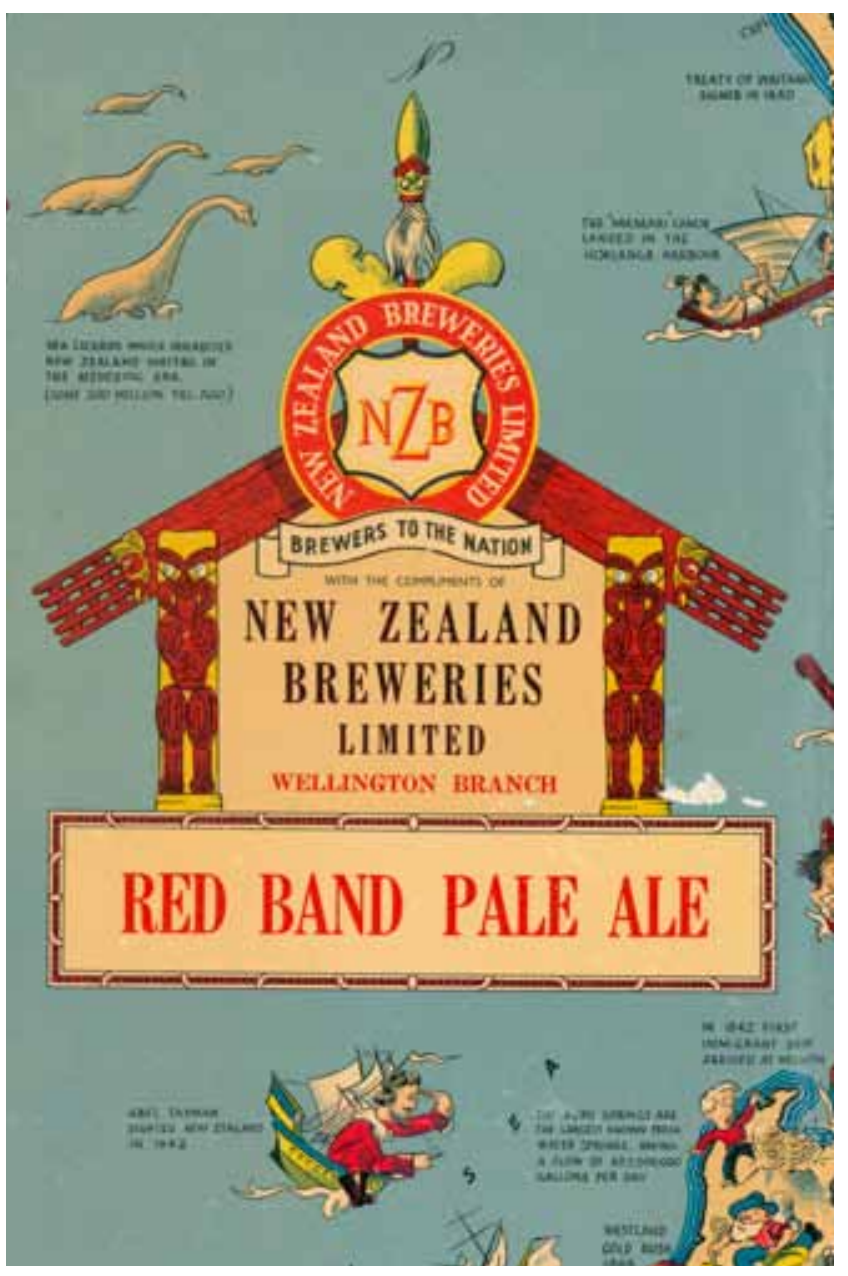

Detail from a map of New Zealand history published by New Zealand Breweries, c 1960. http://ndhadeliver.natlib.govt.nz/ content-aggregator/getlEs?system=ilsdb\&id $=1213768$.

it, to work in a ground floor office in Willis Street as an editor for the School Publications Branch. 'Who am I to complain about being a bureaucrat?' he asked his mother. 'And as you say, one needs to have a regular good income for the family.' ${ }^{4}$ About his pictorial captions, he told her: 'I've quoted freely from NZ landscape poetry in the course of it; and naturally the South Island section is the best'. ${ }^{25}$

The irony Hipkins finds comes from Baxter's identification a decade later of 'a "Tourist Bureau" tradition' in which the poet 'cites landscape photography in particular as the curse of this photography-for-tourist-dollar - for Baxter, as morally repulsive as stealing the original land itself' ${ }^{26}$ Hipkins is discussing a later Baxter project - the text for Ans Westra's Notes on the Country I Live In, ${ }^{27}$ but a similar idea was present in this 1966 poem:

24 James K Baxter to Millicent Baxter, 4 April I962, Baxter family papers, Ms-I136/026, Hocken. 25 James K Baxter to Millicent Baxter, 4 July I96I, Baxter family papers, MS-II36/026, Hocken. 26 Hipkins, 'Dreamers that Struggle to Wake', Handboek, 66.

27 Ans Westra, James K Baxter and Tim Shadbolt, Notes on the Country I Live In (Wellington: Alister Taylor, 1972). 
One kind of love, a Tourist Bureau print

Of the Alps reflected in Lake Matheson

(Turned upside down it would look the same)

Smiles in the dining room, a lovely mirror

For any middle-aged Narcissus to drown in $-^{28}$

Tourists not only faced intellectual disapproval. In I956, while taking 60 delegates of the Commonwealth Press Union around New Zealand, John Hardingham wrote:

Personally, I dislike references to the 'tourist industry'. It is a phrase that seems to reduce the pleasure and informality of a New Zealand holiday to an artificial plane. ... [New Zealanders] will not abase themselves and the tourist by regarding each visitor as an impersonal source of income $\ldots{ }^{29}$

Hugh Hanning in 1957 thought that the New Zealander 'will not make any effort to sell you his country. Nor mercifully does he go around trying to sell it to himself'.$^{30}$ And in 1960, according to Margaret McClure:

New Zealanders remained sceptical about the presence of tourists, their general attitude to complaints being summed up in the rhetorical question, 'If you don't like it, why did you come?' The Tourist Department needed to change the public attitude that tourism was 'close to being immoral'. Worse, this antipathy towards tourism was reflected at the highest level of government. ${ }^{3 \mathrm{I}}$

This level of discomfort with tourism places an argument that the colour pictorials formed a tourist bureau tradition in trouble, given their popularity. The print runs alone make it implausible that tourist souvenirs could have been more than a minor source of sales.

Tourists were not in fact encountered terribly often in the early 1960s. Air travel, especially, had remained difficult since the war. Margaret McClure writes that in I946, 2,576 people visited New Zealand by air and aeroplanes carrying only 40 to 60 people were fully booked months in advance, largely for government or business rather than pleasure. ${ }^{32}$ By 1952, Pan American Stratocruisers were flying direct to New Zealand, and Canadian Airlines linked Auckland with Sydney, Hawaii, and Canada. Cruise ships returned for the first time since the war in 1953, bringing I,000 passengers at a time. ${ }^{33}$ The jet age, with all its associations of style, luxury, afflu-

28 'At Fox Glacier Hotel', 1966, in James K Baxter, Collected Poems, reissue (Auckland: Oxford University Press, 2003), 368.

29 John Hardingham, 'New Zealand - Land of Variety', New Zealand Holiday I (I956), 8.

30 Hugh Hanning, 'Farmer fighter and family man', New Zealand Holiday 5 (I957), I2.

3I Margaret McClure, The Wonder Country: Making New Zealand Tourism (Auckland: Auckland University Press, 2004), 199; the reference to immorality was from Harry G Clement, 'The Future of Tourism in the Pacific and far East' (Washington: US Department of Commerce, I961), I85. 32 McClure, The Wonder Country, 167. That this is the number arriving by air is implied but not stated explicitly.

33 Ibid, I79. 
ence and speed, reached New Zealand in 1963 when BOAC introduced its Comet service from London, taking 37 hours via the Middle East, India, and Singapore. ${ }^{34}$ This inaugurated an era of rapid change. By I965 earnings from the tourist industry were up $36 \%$ on 1963, and visitor numbers doubled between 1965 and 1970, many arriving from Australia. From 1965 to I975 visitor numbers increased on average by $17.4 \%$ each year, against an international average of $6.9 \% .35$ This rapid growth of tourism may have diluted antitourist feeling. ${ }^{36}$

Distinctions can be drawn between these various strands of anti-tourism. Hipkins's use of the tourist bureau is part of a post-I97os move to accommodate particular forms of photography (and not others) within a high art aesthetic. Baxter's excoriation was more clearly linked to his late-I96os renunciation of what he saw as New Zealanders' excessive materialism. All the same, the association of the colour pictorials with tourism is not without foundation. After the end of the Second World War, Kenneth Bigwood worked for the Tourist Department alongside Don Sinclair until the latter moved to Reeds in 1957. At Reeds, Sinclair was responsible for 'tourist supplies', which included slides, postcards, souvenir booklets, plastic tiki, and the production of a regular magazine for the New Zealand Travel and Holidays Association. In I96I, Sinclair offered Bigwood an assignment to travel the length of the country, taking the photographs that would appear in New Zealand in Colour. That, and the suggestion there would be plenty more work thereafter, was enough to persuade him to leave government employment. Promotion of the colour books was explicitly linked with overseas recipients. What needs to be explained, then, is how the colour pictorials successfully reconciled their tourist industry origins and the deliberate emphasis on their international appeal, with the dubious status Pakeha accorded the tourist.

\section{Ibid, 204.}

35 Ibid, 2II-2I2.

36 For example, the Tourist Department official who McClure quotes saying 'Our business is selling pleasure' worked there in the rig7os and rig8os.

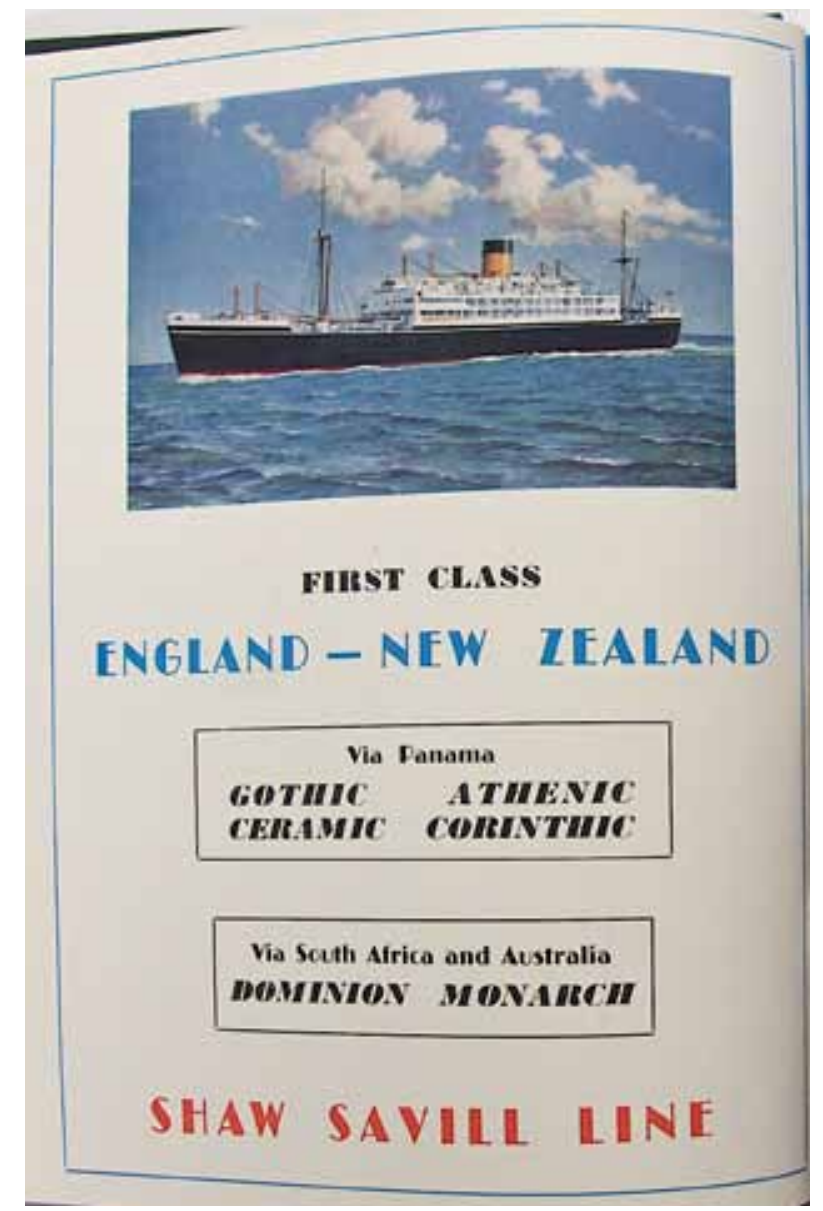

Changes in travel: advertising in New Zealand Holiday magazine in 1957, above, and 1962, below.

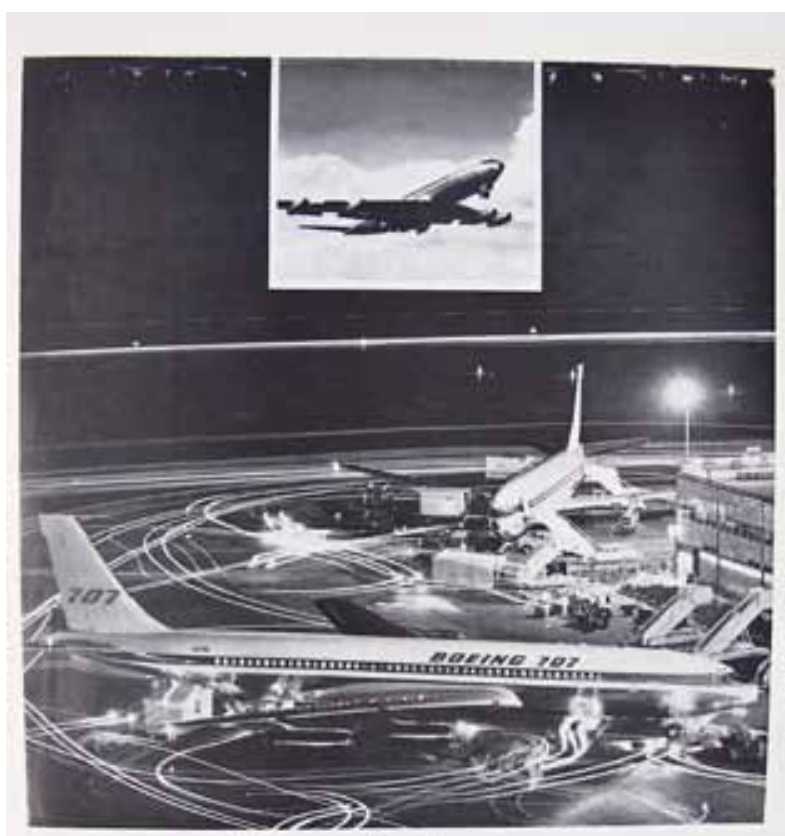

Three fast years

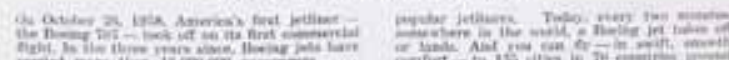

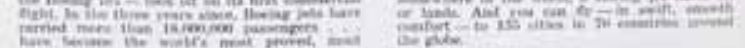
GOEING veriners 40.6- 


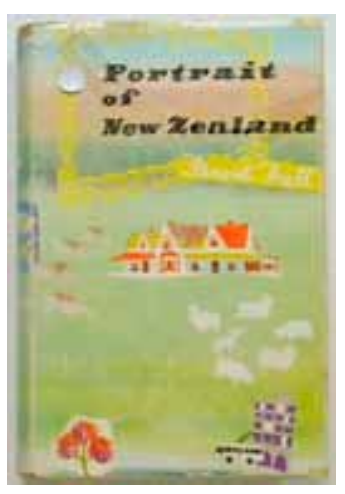

Hardingham's fear that tourism reduced the holiday to 'an artificial plane' is suggestive. Dean MacCannell in The Tourist (1976) was perhaps the first to claim that "the tourist" is one of the best models available for modern-man-in-general' ${ }^{37}$ 'As modern ideas and institutions increase their sphere of influence,' he wrote, 'a mobile international middle class, spearheaded by tourists . . . is widening its base of operations' ${ }^{38}$ MacCannell also noted the concern of the type voiced by Hardingham, that the tourist was 'someone who seems content with his obviously inauthentic experiences' ${ }^{39}$ Inauthenticity, along with commerce and self-indulgence, was constantly in danger of infecting the New Zealand holiday. This enduringly poor reputation can be connected with what James Smithies has argued is New Zealanders' prolonged and strong attachment during the twentieth century to antimodernism. Jackson Lears' formulation of therapeutic antimodernism, which sought to alleviate bureaucratic routine through 'bodily testing', the promotion of good taste, and searches for authentic experience might usefully be applied to the idealised New Zealand holiday. ${ }^{\circ}$ Smithies notes that therapeutic antimodernism was 'in no way antithetical to the lifestyle of a Good Keen Man'. ${ }^{4}$ This distinction is what is missing from the tourist bureau critique: the colour pictorial book celebrated the anti-tourist. In 196I, before the jets arrived, Baxter saw this well enough.

As we saw in chapter I, however, the form of the colour pictorial embodied a kind of deluxe cosmopolitanism. While the colour pictorials were not simply photography-for-tourist-dollar, they inhabited and reproduced a more complex landscape than the anti-tourists may have thought. One of the functions of reproduction was to ensure that the world was always present in New Zealand, and that New Zealand remained present in the world. Even as the growing affluence and cultural reach of the United States began to be felt more insistently, looking at scenery continued to be an important practice that guaranteed Pakeha a place within modernity. Government publishing projects were explicitly founded on ulterior motivations: for D O W Hall's Portrait of New Zealand (published by Reed in I955 and again in 196I, in close association with the Tourist Department), or the department's Wonderland of the South Pacific (1966), or National Parks of New Zealand

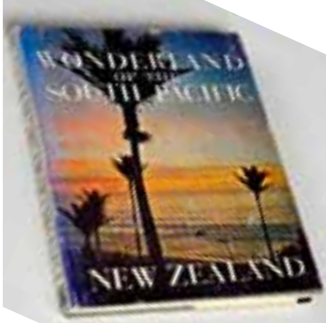
(1965), success would ultimately be measured in visitor numbers. But for Reeds and Whitcombe $\&$ Tombs, success was accounted in sales. While it seems certain that most of the colour pictorials were purchased by and for Pakeha, their suitability for posting overseas to friends and family was prominent in the books' promotion. A significant reason for the colour pictorials' success lay in balancing the validation of modernity alongside anti-modern authenticity. This was not exactly tourism, but

37 Dean MacCannell, The Tourist: A New Theory of the Leisure Class (New York: Schocken Books, I976), I.

38 Ibid, I78.

39 Ibid, 94 .

40 T J Jackson Lears, No Place of Grace: Antimodernism and the Transformation of American Culture, 1880-1920 (New York: Pantheon Books, 198I), 30I-2.

4I James Smithies, 'An Antimodern Manqué: Monte Holcroft and The Deepening Stream', NZJH 40:2 (2006), I74. 
the tourist, as a proxy for modern-man-in-general, had a vital role to play as Pakeha sought to forge and maintain connections with the rest of the world.

\section{Between science and art}

In The Pivot of the World, Blake Stimson claims a historically specific moment for photography in the I950s, in which 'aesthetic pleasure' became a means of 'articulating new relationships to collective identity, new solutions in response to the old collectivisms'. ${ }^{42}$ The aim, he writes, was 'to experience objectivity as a universal identification, to experience the objectivity of "photography itself" as one experiences nation'. ${ }^{43}$ The vehicle for this experience was the photographic essay, positioned between 'the systematic analysis of science' and 'the expressive enunciation of art':

Instead, the essay works between fact and symbol, between comprehension and intuition, between objective understanding and subjective realization in a manner that marks it as a third term, as an alternate way of experiencing and situating one's relation to the world. ${ }^{44}$

The New Zealand colour pictorials, as photo-essays and as books, articulated a similar relationship in which the experience of photography came to be an experience of nation.

One of three "essays" Stimson examines is The Family of Man. Curated by Edward Steichen, it opened at New York's Museum of Modern Art from January to May 1955 and then toured throughout the world over the following decade, with support from the United States Information Agency. It comprised 503 photographs by 273 photographers from 68 countries, and was seen by 9 million people. ${ }^{45}$ The exhibition was not shown in New Zealand as Auckland City Gallery declined the offer. ${ }^{46}$ It did tour Australia in 1959, but not in art galleries: Melbournians saw it at the Preston Motors Show Room, Sydneysiders at David Jones Department Store, Brisbanites in John Hicks Showrooms, and Adelaideians at the Myer Emporium. ${ }^{47}$

The exhibition has attracted much critical hostility, centred on accusations that it was an over-sized Life magazine essay that obscured race and class divisions while asserting a Cold War 'aesthetic colonialism'. ${ }^{48}$ In Alan Sekula's influential I98I analysis:

\footnotetext{
42 Stimson, The Pivot of the World, 26.

43 Ibid, 27.

44 Ibid, 32 .

45 Steichen, The Family of Man, no page number.

46 Janet Bayly, Witness to Change: Life in New Zealand: John Pascoe, Les Cleveland, Ans Westra:

Photographs, 1940-1965 (Wellington: PhotoForum, 1985), I7.

47 Museum of Modern Art (New York), 'Internationally Circulating Exhibitions', list of exhibitions shown outside USA, 1952-2004, http://www.moma.org/docs/learn/icelist.pdf.

48 Lawrence McDonald, 'From The Family of Man to the Family of "Ans"', Handboek, 75; Fred

Turner, Public Culture 24:I (2012) 55-57.
} 

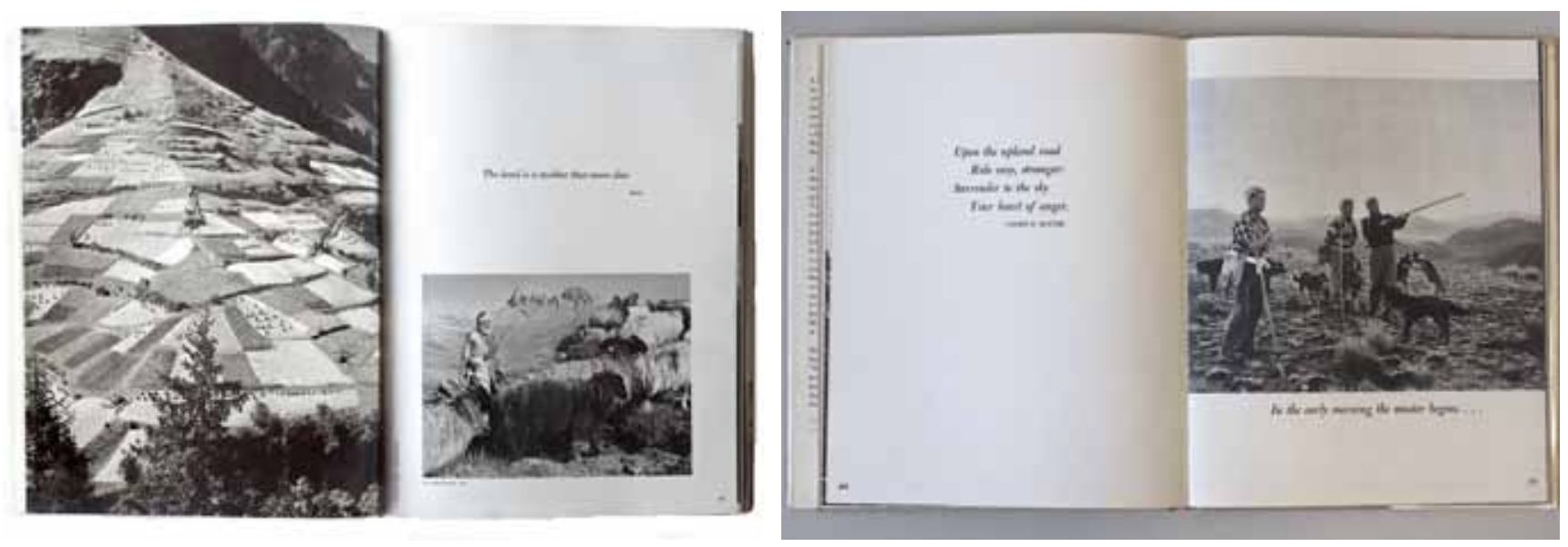

A spread from The Family of Man (left) shows French and Iranian farming next to a Maori proverb; Pakeha musterers (right) are shown alongside James K Baxter's 'High Country Weather' in Gift of the Sea.
The Family of Man universalizes the bourgeois nuclear family, suggesting a globalized, utopian family album, a family romance imposed on every corner of the earth. ... For audiences in the advanced capitalist countries, particularly the United States, the celebration of the familial sphere as the exclusive arena of all desire and pleasure served to legitimate a family-based consumerism. ${ }^{49}$

Yet the exhibition had a profound effect on photography in New Zealand. Ans Westra and Marti Friedlander both credited its impact on their photographic practice. The book of the exhibition (continuously in print since 1955) heavily influenced the layout of Westra's Maori, published by Reeds in 1967, and Brake and Shadbolt's Gift of the Sea. ${ }^{50}$ Westra, Friedlander, and Brake are named by Janet Bayly among the 'handful' of pioneers of documentary photography in New Zealand. ${ }^{51}$ Both Westra and Friedlander have described their work as expressing a distance from what they saw as the New Zealand mainstream. ${ }^{22}$ The complexities of the show, and responses to it, are acknowledged in more recent analyses of The Family of Man. Fred Turner has argued that the exhibition's creators were motivated by a 'deeply democratic' and antiauthoritarian impulse that stemmed from the experiences of the Second World War. ${ }^{53}$

With respect to the colour pictorials, there is more to say on Sekula's observations about the family, but first Stimson's argument about 'photography as nation' needs to be addressed. Kyla McFarlane writes that Maori 'draws on Steichen's universalism in order to depict the lives of a specific ethnic group'. ${ }^{44}$ In Pakeha New

49 Alan Sekula, 'The Traffic in Photographs', Art Journal 4I:I (Spring 198I), 19, 20. 50 Kyla McFarlane, 'Sentences Forming Stories: Ans Westra”s Maori and Edward Steichen's Family of Man', in Handboek, 5I-6I, 74.

5I John Pascoe and Mahara Gallery, Songs of Innocence: Photographs of a New Zealand Childhood (Wellington: Pacific Press, 2005), inside front cover.

52 See McDonald, ed., Handboek; Westra, Baxter, Shadbolt, Notes on the Country I Live In; Marti Friedlander and James McNeish, Larks in a Paradise: New Zealand Portraits (Auckland: Collins, 1974); Leonard Bell, Marti Friedlander (Auckland: Auckland University Press, 2009).

53 Turner, 'The Family of Man and the Politics of Attention', 57.

54 McFarlane, 'Sentences Forming Stories', Handboek, 52, 56. 
Zealand (the earlier discussion of the tourist helps clarify this), the experience of objectivity as a universal identification did not take place though handling books about Maori, but through books about scenery. Indeed, the prominence of Maori in Gift of the Sea did not always sit well with Pakeha. ${ }^{55}$ An interest in the reception of images is well suited to investigating the colour pictorials' appeal. Reeds and the Bigwoods did not explicitly reproduce the (American) form of The Family of Man, instead, as we saw in chapter I, choosing to follow British and European models. And although the Bigwoods' images were not documentary photography, Pakeha valued them for showing New Zealand as (they could believe) it really was: for the quality of the technical and literal reproductions. Viewers were what bound Brake and the Bigwoods together with New Zealand. Both essays:

simultaneously create a physical momentum between individual photographs and a psychological movement in the viewer as he or she comprehends and identifies with the content of the images while turning the pages of a book . . . ${ }^{56}$

Another way that the colour pictorials articulated a relationship to collective identity was in the notion of completeness. A proposal for a pictorial book was first put to Reeds in 1957 by Rhodesian-born photographer Joy Horwood. Horwood had worked in London for Marcus Adams, the Royal family's photographer, and later the South African government commissioned her to produce a series of photographs that would be toured in Australia and New Zealand as a public relations exercise. ${ }^{57}$ At Reeds, Richards and Don Sinclair were interested, and discussed co-publishing in London with Thames and Hudson. $5^{8} \mathrm{New}$ Zealand Listener editor Monte Holcroft was commissioned to write a 25,000-word introductory essay.

Horwood then married a West Australian farmer, and although in 1959 she indicated to Richards that she would return to New Zealand to complete the project, it never happened. In May 1960, Richards reported to his fellow directors that:

Very careful examination of the photographer's material showed such serious deficiencies that a very intensive programme would be needed to bring it up to reasonably full completeness, and even then the quality was only fairly good and certainly not high. We presented Joy Horwood with a detailed list of omissions and inadequacies and I have now heard from her to say that she realises that the task was beyond her in the short time she was in New Zealand. ${ }^{59}$

Sinclair and Richards were 'frankly relieved', not least because they had been simultaneously discussing virtually the same project with Brake, but the lack of

55 Jocelyn Chalmers, conversation with the author about the book's reception in Southland. 56 Maia Dauner, review of The Pivot of the World, InVisible Culture, http://ivc.lib.rochester.edu/ portfolio/the-pivot-of-the-world-photography-and-its-nation/.

57 This seems to have happened in 1956 and 1957. Her images were re-exhibited in Perth in 2010: Foto Freo 2010 Programme: The City of Fremantle Exhibition of Photography, http://www.inmycommunity.com.au/_uploads/PDF/FotoFreo_20Io_Programme.pdf.

58 Ray Richards, in 'Executive Notes' 14 October 1959, I52, Reed Publishing records, MSX-8I02, ATL. 59 Ray Richards, report, II May 1960, 'Executive Notes, 1960', 302, Reed Publishing records, MSX-8IO3, ATL. 


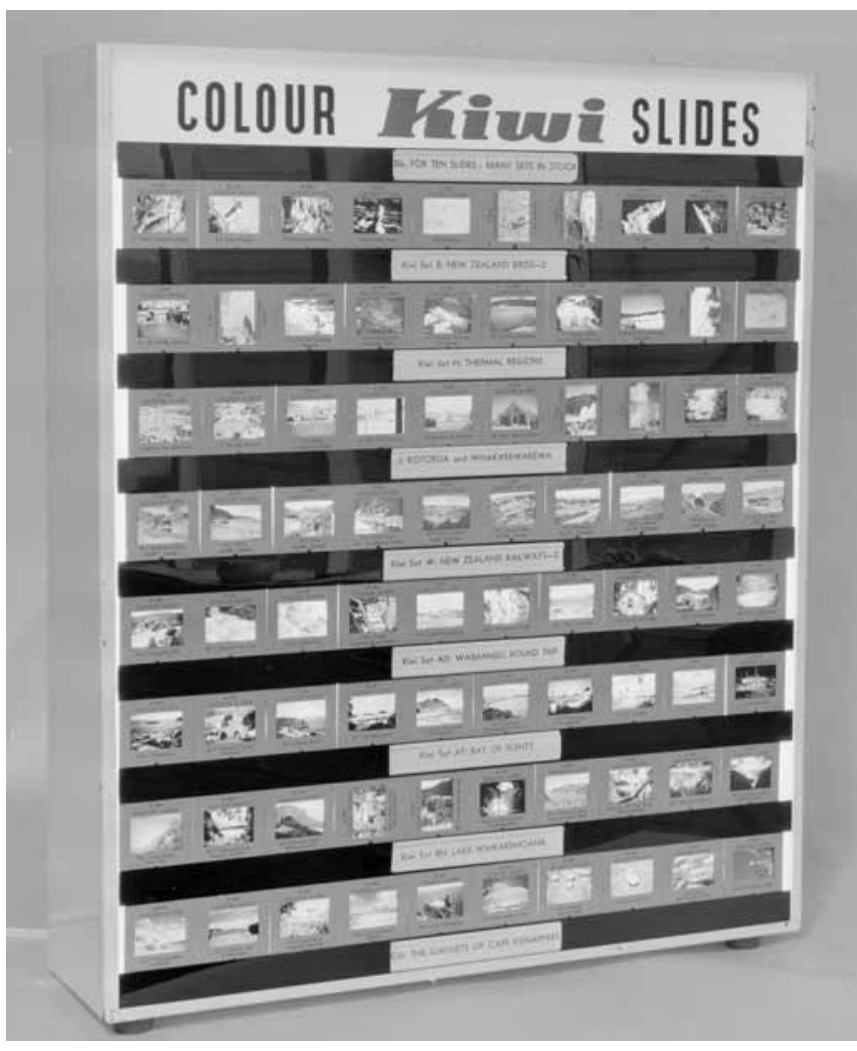

Display of Reeds' 'Kiwi' colour slides.

KE Niven and Co, commercial negatives, 1/2-214735-F, ATL. http://natlib.govt.nz/records/22841671. comprehensive coverage was the deciding factor. But with Brake proving hard to pin down, Sinclair contacted Ken and Jean Bigwood. They were interested but time was short, and Sinclair warned the directors that a book 'may sell because it is the first in the field, but if the coverage is not good, criticism is bound to result' ${ }^{60}$ Briefing the Bigwoods late in r960, he told them:

Geographical coverage is important. We must give both islands approximately the same number of plates and it should be borne in mind that if any province is left out the book will lose potential sales in that province. While tourist resorts play a vital part in the coverage and the main ones must be included, the hackneyed 'touristy picture' is to be avoided at all costs. ${ }^{6 \mathrm{I}}$

They were to obtain roo 'descriptive' colour images of New Zealand, providing 'a scenic coverage of the country'. Sunsets, sunrises, storms, mist and rain were secondary to the main objective: pictures that were 'well-defined, clear and of correct colour balance'. While long shots of built-

up areas were acceptable, 'pictures which tell the story of the hand of man on the landscape are essential'. 62

Much of Sinclair's working life revolved around lists. He chose images from local photographers to be duplicated in West Germany, and packaged and re-imported as sets branded 'Kowhai', 'Kiwi', and 'Maoriland'. Obtaining a good image of boiling mud was a long-standing problem. He organised production, distribution and sales of postcards, pictorial guides to tourist attractions such as Waitomo, Milford, and Rotorua, and 'many thousands' of imitation greenstone tiki. His reports to directors were filled with lists of scenic features, appropriately grouped into marketable sets, and records of sales. Comparing the Bigwoods' brief to the tourist lists, there are strong similarities, but the colour pictorials would not be just another tourist supply. The demand came from local booksellers. Tom Kennedy, Reeds' sales manager, reported in July 1959 that 'two books continually being asked for by the trade all over the country' were a cloth-bound book of birds and 'one which has been discussed at length many times': 'A book on New Zealand in colour with little or no text and a retail price of something in the vicinity of $42 s^{\prime}$. Kennedy

60 Don Sinclair, report, 9 November, 'Executive Notes, 1960', 569, Reed Publishing records, MSX-8IO3, ATL.

6I 'NZ in Colour: Photography', attached to briefing to John Pascoe for New Zealand in Colour Volume Two, I4 February 1962, John Pascoe papers, Ms-papers-8I79-3I, ATL.

62 Ibid. 
thought it certain that someone would publish such a book, but that it was 'our prerogative'. ${ }^{6} 3$ When New Zealand in Colour appeared, the dust jacket praised the Bigwoods:

The coverage they achieved embraces the whole country and gives a representative and integrated picture of New Zealand and its great variation of scene and setting. ${ }^{64}$

Viewers and readers could embrace the whole country by turning the pages: in the movement of eyes, hands and fingers, perhaps even in supporting the weight of the book on a lap, Pakeha New Zealanders moved from place to place. An idea of nation formed in the seriality of this collective photo album. If scenery looks an unpromising place through which to search for what Stimson suggests is representation's opposite - lived experience - the experience that mattered was the consumption of the book, by which the colour pictorials enabled 'embodied looking'. ${ }^{6}$

The supposedly baleful influence of the "Tourism Bureau" has obscured the way the four New Zealand pictorial books discussed here succeeded in creating an experience of nation that could also be intrinsic to universalising ambitions. But scenery had never been regarded as being only for the benefit tourists. In 1955 , reprising his centennial survey of I940, Oliver Duff, wrote that:

if nature 'shows off' a little in England, she struts through New Zealand an unblushing exhibitionist. In no other country of comparable size has she abandoned herself quite so wantonly. ${ }^{66}$

Duff admitted to being 'cheaply provocative and deliberately rash', but the point was, all that showing

63 Tom Kennedy, report, 'Executive Notes', July 1959, 62, 70, Reed Publishing records, MSX-8102, ATL.

64 Bigwood and Baxter, New Zealand in Colour, dust jacket. 65 Stimson, The Pivot of the World, 56-58.

66 Oliver Duff, New Zealand Now, 2nd ed. (London: Allen $\&$

Unwin, I956), 4.

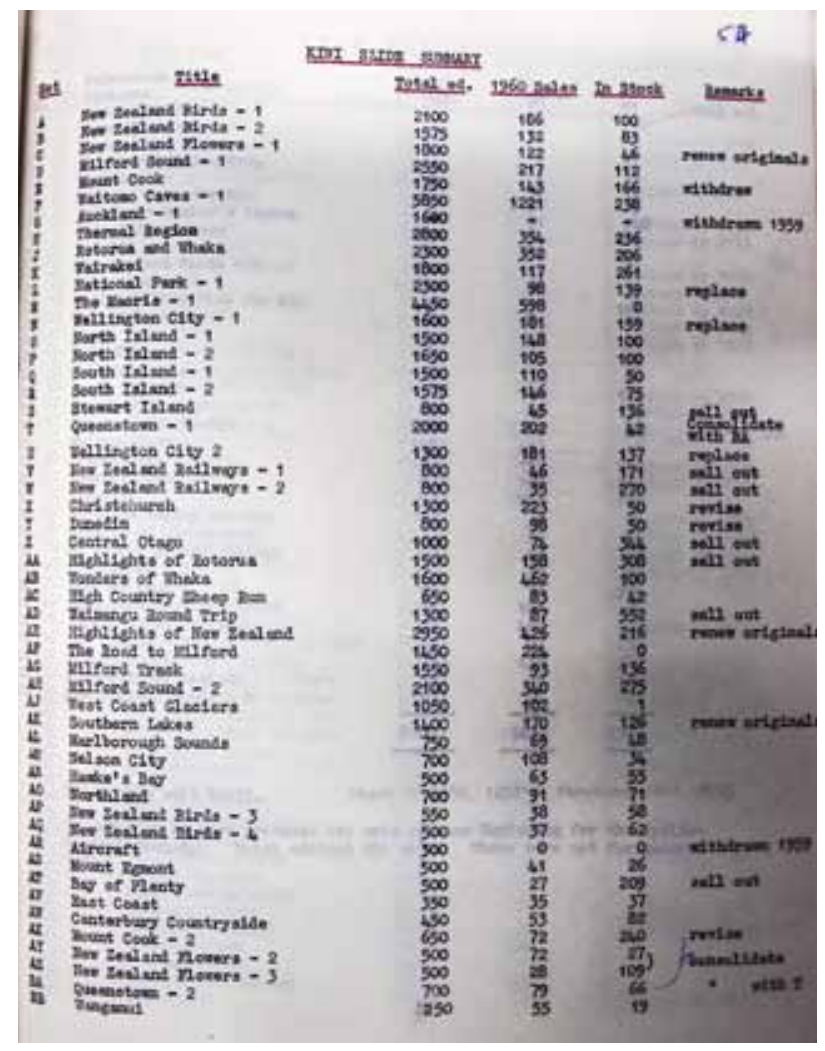

Don Sinclair, Kiwi Slide Summary, 'Executive Notes', MSX8103, ATL.

Don Sinclair, briefing notes for New Zealand in Colour, Volume Two. Many of the photographs are views from the 'highway'. John Pascoe papers, MS-papers-8179-31, ATL.

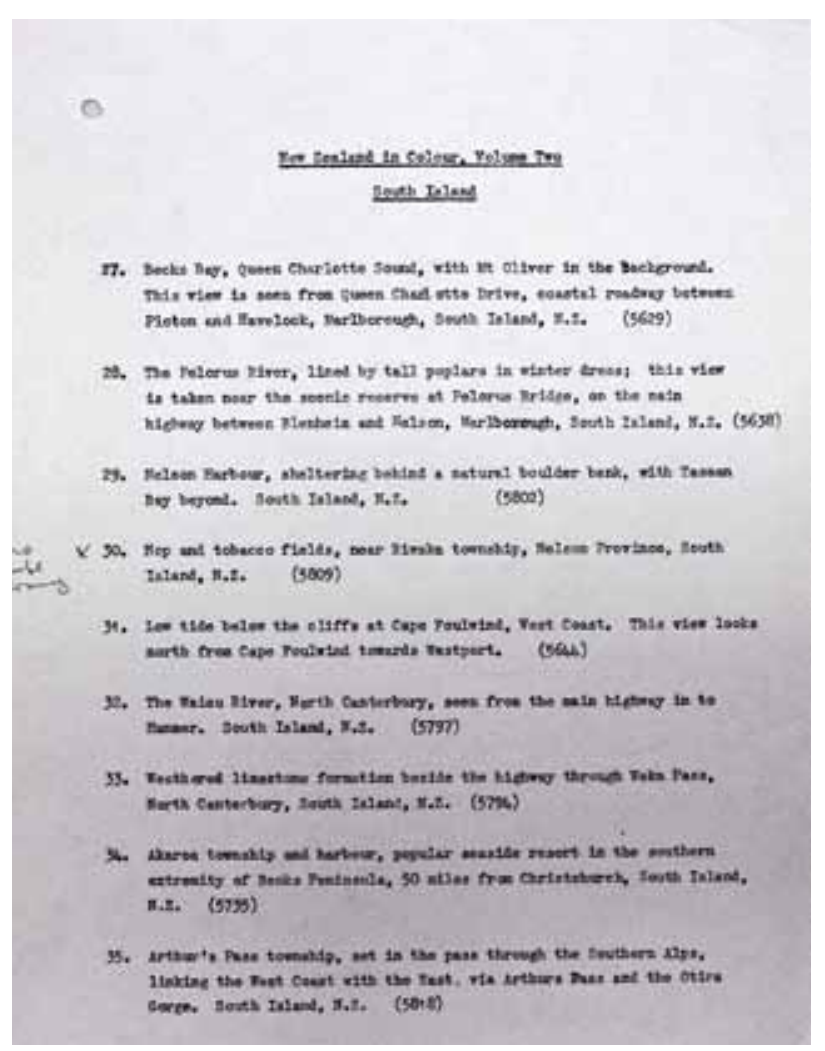


off connected New Zealand to the world ${ }^{67}$ Scenery had always been the way that others saw New Zealand, so it was logical that it should also take an essential role in forming the Pakeha view of their country. A triangulation took place, which involved looking at the view while keeping an eye on others looking at the view.

\section{Realism above that noticed even at the actual scene}

If tourism was difficult to accept, holidays were not. The practices of holidaying and thumbing through pages were mutually reinforcing, not least because the experience of nation through physical and psychological movement occurred behind the windscreen as well as in books. Photography was important for both, and the popularity of colour books in 196I was accompanied by growing enthusiasm among amateur photographers for colour. Kodachrome II, introduced in 1961, was promoted as being $2^{1 / 2}$ times faster than regular Kodachrome, and this meant it was just possible to take a sharp photograph of a still scene on a sunny day. ${ }^{68}$ Colour still meant slides: the carousel projector was introduced the same year, and Kodak began processing slide film in Coburg, Melbourne. Alan Buckingham advised readers of New Zealand Camera magazine: 'Viewing your slides allows you to relive that trip or holiday, and your friends to enjoy your photographic experiences with you.' Using a projector and colour slides was the 'absolute ideal': 'the colours have an added brilliance and realism above that noticed even at the actual scene'. ${ }^{69}$ Full-page display advertisements for colour films were prominent in the magazine, although it was produced in black and white.

The expense of film and processing, together with the effort of display, meant slideshows commonly displayed the results of significant travel. After returning from India, Baxter wrote to his mother:

You were wondering how I got on with colour slides. Yes, I did manage to get some, not as many as I would have liked, but valuable all the same. Some time I must do what you suggested before I left - come down to Dunedin and give a talk on India $\&$ Japan, using a slide projector. ${ }^{70}$

Two years later he obtained a projector for his mother, costing $£ \mathrm{I} 2 / 4 /$-. 'You will probably be able to make much more use of it than we could have,' he wrote.

67 It still does, as the 100\% Pure tourism campaign and the Lord of the Rings and Hobbit films show. In May 2013, Minister for Economic Development Steven Joyce announced the Government would need to spend $\$ 2$ million in order to broaden 'New Zealand's international brand beyond the scenic beauty of the country': New Zealand Government, 'Budget 2013: \$2m for "New Zealand Story” project', press release, 20 May 2013, http://www.scoop.co.nz/stories/PAi305/So0397/ budget-2013-2m-for-new-zealand-story-project.htm.

68 'Faster and better ...', New Zealand Camera 9:I (January-March 1962), 4I; Michael Roman, 'The Sunny I6 Rule’, Boston West Photographic Society, http://www.bwps.org/res/tips/sunny_i6/. 69 Alan Buckingham, 'Slide Projection', New Zealand Camera 9:I (January-March, I962), II. 70 James K Baxter to Millicent Baxter, 25 June 1959, Baxter family papers, MS-II36/026, Hocken. 

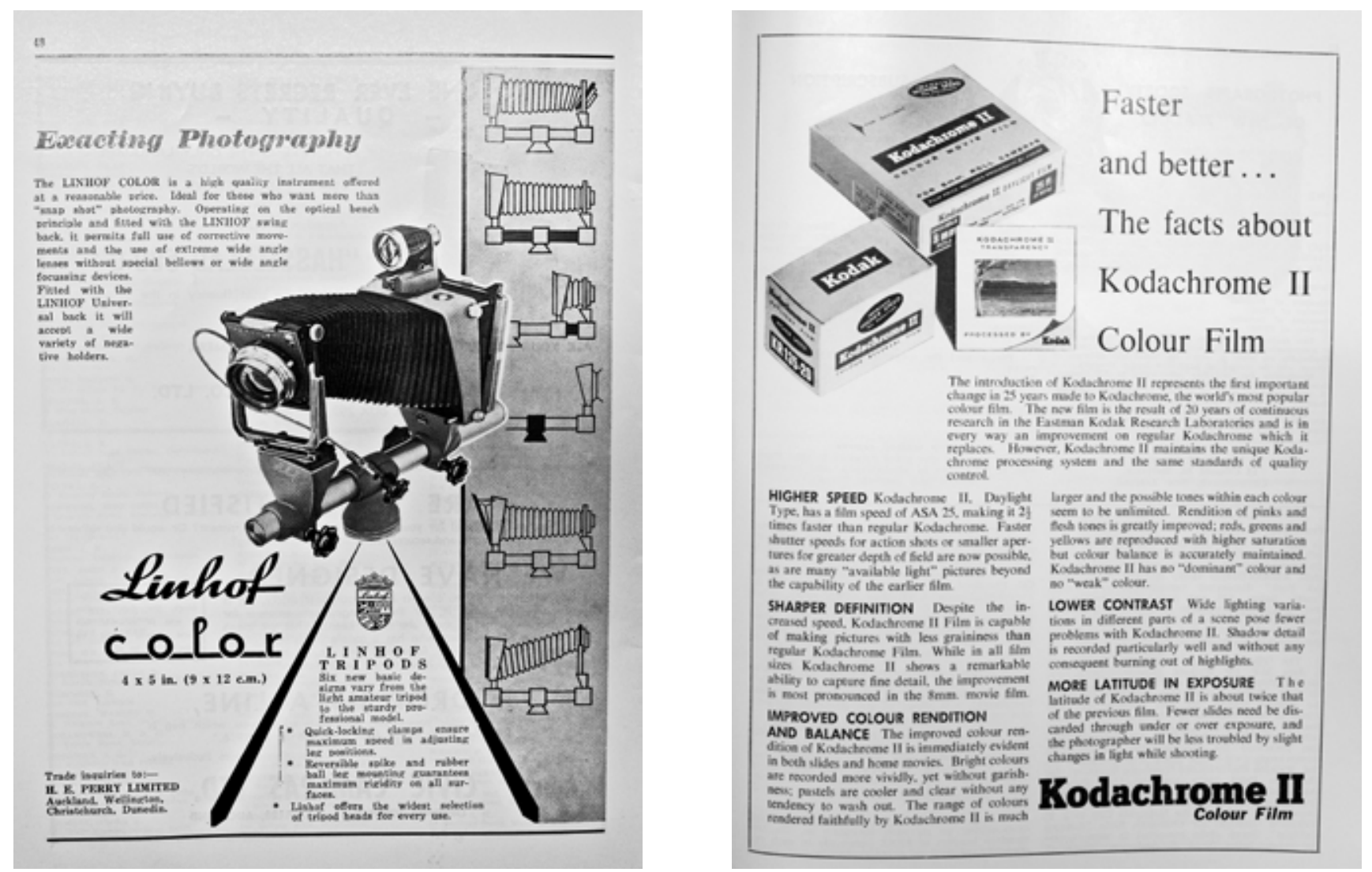

Advertisements in New Zealand Camera, vol 8:4 (October-December 1961). Left:This Linhof colour camera produced $4 \times 5$ inch negatives and would have been similar to those the Bigwoods used. Right: Kodachrome II slide film was 'Faster and better'.

I imagine your collection of slides is increasing steadily.'7x Showing a facility for technical writing, he then listed eight points ,(a) to (h), about projector use.

Not everyone enjoyed slideshows. Clif Reed complained to his uncle:

So many people take their own coloured photographs, and I groan every time when an entertainment at somebody's home means looking at slides. There was a terrible example ... a few years ago - he went home to Scotland, was not a good photographer, not used to taking coloured photographs, and it was raining pretty well all the time that he was there ... and I disgraced myself for all time by falling asleep and snoring, until I was woken up! ${ }^{72}$

Extensive travel through New Zealand was still relatively difficult to achieve. After emigrating to Auckland, camera club member Rich Singleton found: 'Whenever we expressed appreciation of our new life and surroundings the inevitable reply was forthcoming: "Wait until you see the South Island". But short annual holidays meant it took ten years for the trip to become reality. Rather than stay in hotels, or under canvas in motor camps, the Singletons purchased a Volkswagen

7I James K Baxter to Millicent Baxter, I7 July I96I, Baxter family papers, MS-II36/026, Hocken Library.

72 A W Reed to AH Reed, 27 July 1962, A H Reed papers, 75-053-4 flr 2, ATL. 
Kombi, to which a cabinet-maker friend fitted a dinette, topped in formica, which converted to a double bed. The highlight proved to be an autumn weekend in Wanaka, 'where we shot more film in a few days than we had done all the rest of the holiday'. ${ }^{73}$ In Julie Maree Benjamin's analysis of Auckland woman Gladys Cunningham's slide photography, she notes that travel throughout New Zealand only became possible once Gladys's children had grown up.

The connection between one's own pictures and those sold by Reeds as slide packs or in books was understood. For Cunningham, gaps in holiday coverage due to weather, lack of time, flawed technique, or simply not seeing 'what they anticipated seeing' could be filled with Reeds' slides. Such images, Benjamin writes, could assist the amateur by demonstrating how the professional 'framed those attractions' ${ }^{74}$

Photography and holidaymaking were also linked in the colour pictorials. The first sublime colour plate in New Zealand pictured the Southern Alps near Fox Glacier, framed by ancient kahikatea trees. It was succeeded by an image of canvas tents beside a parked car, with the beach just beyond and two figures on the shore beside a small boat. Otautu Bay, at the northern end of the Coromandel Peninsula, was typical, the caption said, of places where 'wandering motorists' would find 'a good camping ground, a safe beach for bathing, and tracks which invite climbers into the ranges' - things 'sought by holiday-makers . . . especially in the summer weeks after Christmas'.

\section{Christmas in the sun}

Although the summer holiday gained importance in the late nineteenth century, during the postwar decades it became a true marker of Pakeha New Zealand life. ${ }^{75}$ From 1936, a 40-hour week and two-day weekend became the norm, and factory workers were guaranteed eight public holidays. The Annual Holidays Act 1944 provided two weeks' annual leave for all workers. For men, at least, working was almost universal: the officially unemployed numbered fewer than Ioo between 1948 and 1955 and did not rise significantly until after $1967 .{ }^{76}$ In the summer of $196 \mathrm{I}-62$, as New Zealand in Colour went on sale, New Zealand Holiday magazine claimed that 'summer brings Christmas and the sunshine of a fiesta. It's the great time of the year for New Zealanders and for their guests from other countries'. Even in the tourism industry's official publication, tourists were still guests, and after the

\footnotetext{
73 Rich Singleton, 'The Right Kombination', New Zealand Camera 9:3 (July-September 1962), I8-19. 74 Julie Maree Benjamin, 'Transparencies: New Zealand from I953 to 1974 through the Slide Photography of Gladys Cunningham’ (PhD thesis, University of Auckland, 2008), 190-192. 273-274

75 For the nineteenth century, see Alison Clarke, Holiday Seasons: Christmas, New Year and Easter in Nineteenth-century New Zealand, (Auckland: Auckland University Press, 2007). 76 Trade Union History Project, Workers' Holidays in New Zealand: A Brief History (Wellington: Trade Union History Project, 1997), 2I-22; Melanie Nolan, 'Constantly on the Move but Going Nowhere?' in Giselle Byrnes, ed, New Oxford History of New Zealand, 375-6.
} 


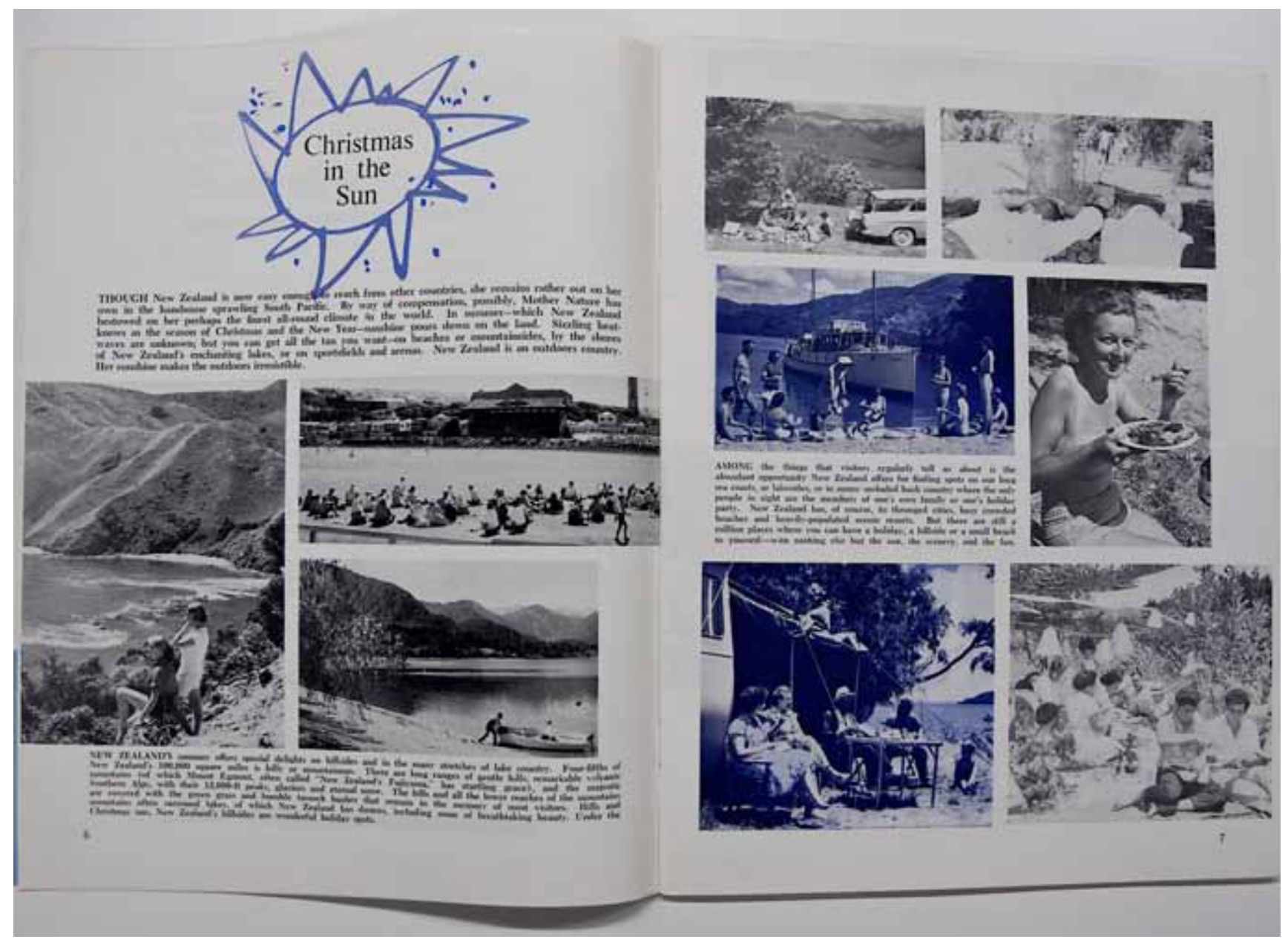

‘Christmas in the Sun', New Zealand Holiday 2:4 (December 1961), 6-8.

sunshine the main selling point was that there were 'a million places where you can have a holiday, a hillside or a small beach to yourself' ${ }^{77}$

How did the image match reality? Kirstie Ross writes: 'By the 1950s, there was a popular and convenient assumption that New Zealand workers and their families preferred to camp when they went on holiday.' Ross argues that 'convenience trumped sublime scenery' for many, and motor camps and caravan rallies tended to be located near major population centres, on flat ground with safe play areas for children. ${ }^{78}$ Holcroft's Otautu Bay caption did not make explicit who the holidaymakers were, but a good campsite and safe bathing were endearing to families. A brief survey of the summer holidays taken by the men most closely involved with the colour pictorials supports the suggestion that sublimity was more frequently sought on the page than at the beach, but indicates that the campground itself was

77 'Christmas in the Sun', New Zealand Holiday 2:4 (December 196I), 6-8.

78 Kirstie Ross, "We Bring Our Vans from Near and Far”: Family Holidays in New Zealand after the Second World War', unpublished conference paper, Stout Research Centre, Victoria University of Wellington, I September 20II, 6-9. 
less integral to the summer holiday than two other factors: the motor car and the family.

Family commitments determined James K Baxter's holidays, as they alternated between Napier, where Jacquie's parents lived, and Brighton, the home of Millicent and Archibald Baxter. In August 1959, James wrote to his mother that:

Jacquie now has her driver's licence - so I was able to go up with her on Saturday to Napier, each of us driving approximately half of the way. I hope to get a licence myself before the end of September. I felt rather pleased with myself for driving through the Manawatu Gorge. We got up in good time, with no difficulties apart from the tendencies of the children to grizzle $\&$ pound each other in the back seat - natural on a long journey - grave threats had to be made at intervals. ${ }^{79}$

If the pages of NZ Motor World are any guide, it was unusual for a wife to drive, let alone be the first to obtain a licence. ${ }^{80}$ Christmas that year was spent in Brighton with James's parents. The following August the family again drove to Napier; James returned the next day to work, while the others stayed for the school holidays. In July 196I, he was perhaps feeling flush after finishing work on New Zealand in Colour. It had been 'quite a big job, for which I have had $£ 25$, will probably get $£^{25}$ more tomorrow, and $£ 75$ on publication'. In any case, Baxter booked to take his car south to Brighton over Christmas 'on ferries', travelling south to Picton on 15 December and back from Lyttelton on 2 January $1962 .{ }^{8 \mathrm{I}}$

The Pascoe family best approached Holcroft's holiday ideal. They did not own a car and, as Dorothy Pascoe remembered, they 'made an advantage of that' by taking holidays 'in places cars couldn't go'. Many summer holidays were spent camping at different places in the Marlborough Sounds. ${ }^{82}$ Late in 1960 they crossed Cook Strait in a ketch and spent three weeks on D'Urville Island before being picked up again and returned to Wellington. But the following summer was very different. In the first months of 196I John Pascoe faced a gruelling employment dispute that ended with the loss of a new job as Controller of the Wildlife Service after an unsuccessful applicant appealed the appointment. He was reassigned to other duties with the Department of Internal Affairs but on a reduced income, and in January 1962 the Pascoe family, John, Dorothy, and elder daughters Anna and Sara, spent three weeks picking raspberries at Tapawera, near Nelson. They earned between $£$ I7 and $£^{20}$ each. ${ }^{83}$

Early in 1962, Reeds offered John a $£$ ioo advance and a further $£$ ioo on publication to produce the text for a second volume of New Zealand in Colour. This

79 James K Baxter to Millicent Baxter, 24 August 1959, Baxter family papers, MS-II36/026, Hocken. 80 The regular women's page at the rear of NZ Motor World contained advice such as recommending a woman learn to drive before marriage, as husbands would never willingly give up their steering wheel; see also Benjamin, 'Transparencies,' 286-290, and Graeme Davison with Sheryl Yelland, Car Wars: How the Car Won Our Hearts and Conquered Our Cities (Sydney: Allen \& Unwin, 2004), ch 2.

8I James K Baxter to Millicent Baxter, 4 July I96I, Baxter family papers, MS-II36/026, Hocken.

82 Pascoe and Mahara Gallery, Songs of Innocence, 59-Ioo, esp 68.

83 Chris Maclean, John Pascoe (Nelson: Craig Potton, 2003), 253-259. 
was a significant sum of money when, for example, a male metalworker's weekly minimum wage was about $£^{\mathrm{I} 4}$, but John and Dorothy agreed not to spend it. ${ }^{84}$ In August that year he wrote to his sister Alice, lamenting that he had been unable to visit the 'Ruapehu snows' as 'we live from one pay day to the next and have no spare cash'. Nevertheless, that Christmas the family travelled to Arthur's Pass. ${ }^{85}$

Clif Reed tended to take his holidays later in summer, partly because there was no requirement to visit family outside Wellington, but also because Christmas came during the firm's busiest period. Late in March 1962, he combined a business trip to Auckland with a motor journey around the east coast with his wife Retta:

I'm not quite sure how we'll go from Tauranga to Gisborne, but I think we'll go through the Waiweka [Waioeka] Gorge; though it depends on how much time there is, of course. It would be nice to go by the coast road if we have time. ${ }^{86}$

Ray Richards kept A H Reed appraised of developments, writing that Clif 'dashes around the North Island'. But the conventional wisdom that holidays improved the health of workers and their families failed Retta. From Tauranga, Clif wrote that her asthma 'may possibly have been caused by the dusty road because we came down through Clevedon, the route by which we returned from Coromandel to Auckland a few years ago'. Retta thought she might be improving and wanted to go on to Gisborne, but it proved to be 'hot and muggy most of the time' and the trip home from Gisborne, especially, was extremely difficult for her. ${ }^{87}$

The experience must have been chastening, for by May Clif had decided on holidaying closer to home:

I mentioned [to Retta's doctor] before I went to Auckland that instead of going away on holidays etc. which don't seem to do any good, it would be better to get a beach cottage where we could go on occasional days, weekends etc whenever we felt like it ... Almost fortuitously we found an ideal place at Raumati $S$ which has a lovely climate - two bedrooms, lounge etc, garage $\&$ outside bedroom, magnificent view, private, sheltered, sun all day, \& private steps down to the beach. So I've bought it. ${ }^{88}$

As managing director, Clif was the wealthiest

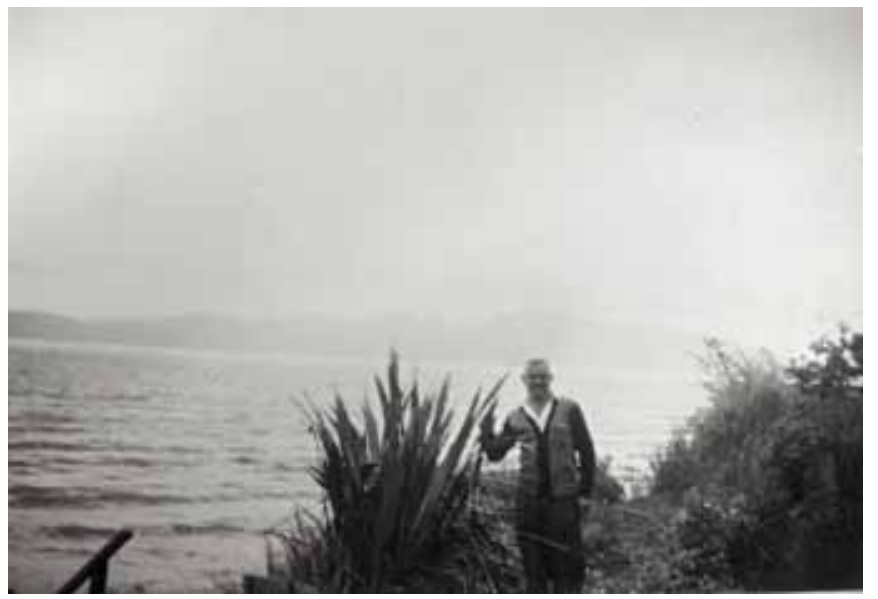

Clif Reed at Raumati, [1960s]. AW Reed and family photographs, PAColl-3437, ATL. of the pictorial men, but not the only New Zealander looking to reproduce home on holiday. The number of holiday homes increased by a

84 John Pascoe to Anna Pascoe, 4 March 1962, Pascoe papers, Ms-papers-8179-3I, ATL.

85 Maclean, John Pascoe, 26I, 265.

86 AW Reed to AH Reed, I4 May 1962, AH Reed papers, 75-053-4 fldr 2, ATL.

87 Ibid.

88 Ibid. 
third between the 1956 and I96I censuses, from 19,899 to $26,518 .{ }^{89}$ In 1926 there had been 7,000, many of them informal, haphazard structures, more like 'a packing case than human living quarters'. Coastal areas near main centres continued to be favoured, but as roads and vehicles improved more distant locations such as Taupo and Wanaka developed..$^{\circ}$

At the beginning of 1960, Maurice Shadbolt returned to New Zealand after spending several years in London and travelling through Europe. He was immediately offered an assignment to write an article on New Zealand for National Geographic, for the large sum of us $\$ 2,000$ plus us $\$ 500$ expenses. The deal was arranged through Brian Brake, and the pair duly drove across the country between February and May, from Russell in the north to Dunedin in the south, in Brake's 'shiny Jaguar. ${ }^{91}$ At the end of the year Shadbolt left Te Marua with his wife Gillian and one-year-old son, in a second-hand car they had bought with the final £300 royalty cheque from his book The New Zealanders: 'we pushed it hundreds of miles, from one end of summer to the other', he remembered in 1999. The family drove to Waihi for Christmas, where Shadbolt's parents lived, and then on to Cape Reinga for New Year. At the end of 196I, with another child due, he left family behind to cover the independence of Samoa on New Year's Day 1962, for National Geographic. There is no mention of holidays later that summer in his memoir, only long hours working in a bakery. ${ }^{92}$

In January 1962, Jean Bigwood described for readers of the Automobile Association's Motor World newspaper a journey around New Zealand. In the paper's 'with Caravan Tent or Trailer' section the story was headlined: 'Man- $\&$-Wife Camera Team Travels 9000 Miles To Capture New Zealand In Colour'. ${ }^{93}$ Together with a EI,O00 payment for Ioo colour photographs of New Zealand, Reeds paid a further $£$ I25 to hire a caravan for the year-long safari. The Bigwoods' Landrover pulled the extra-large caravan (and a budgerigar) for nearly 6,000 miles around the North Island, with the remainder in the south. For Motor World's readers, Jean was among the most venturesome of travellers, the Landrover affording travel into 'unroaded areas where no ordinary car would dare to go' ${ }^{94}$ Caravanning was a variety of holiday made possible by better roads and more powerful and reliable vehicles - Kirstie Ross notes that the Wellington Caravan Club had to create a waiting list for new members in 1958. But travel was still slow in comparison with today: it took nine hours to reach Tongariro National Park from Wellington. ${ }^{95}$ Towing both caravan

89 Department of Statistics, The New Zealand Official Year-book, 1962, http://www3.stats.govt.nz/ New_Zealand_Official_Yearbooks/1962/NZOYB_1962.html.

90 Neill Atkinson, "“Call of the Beaches": Rail Travel and the Democratisation of Holidays in Interwar New Zealand', Journal Of Transport History 33:I (June 20I2), 9, 19. The quote is from Evening Post, 29 December 1933, 3 (in Atkinson, 9).

9I Maurice Shadbolt, From the Edge of the Sky: A Memoir (Auckland: David Ling, 1999), 36, chs 6-8.

92 Ibid, 66-69, 82-88.

93 Jean Bigwood, 'Man-and-Wife Camera Team', NZ Motor World 26:II (January I962), 20-2I. 94 Ibid.

95 Kirstie Ross, Going Bush: New Zealanders and Nature in the Twentieth Century (Auckland: Auckland University Press, 2008), I5I-I55. 


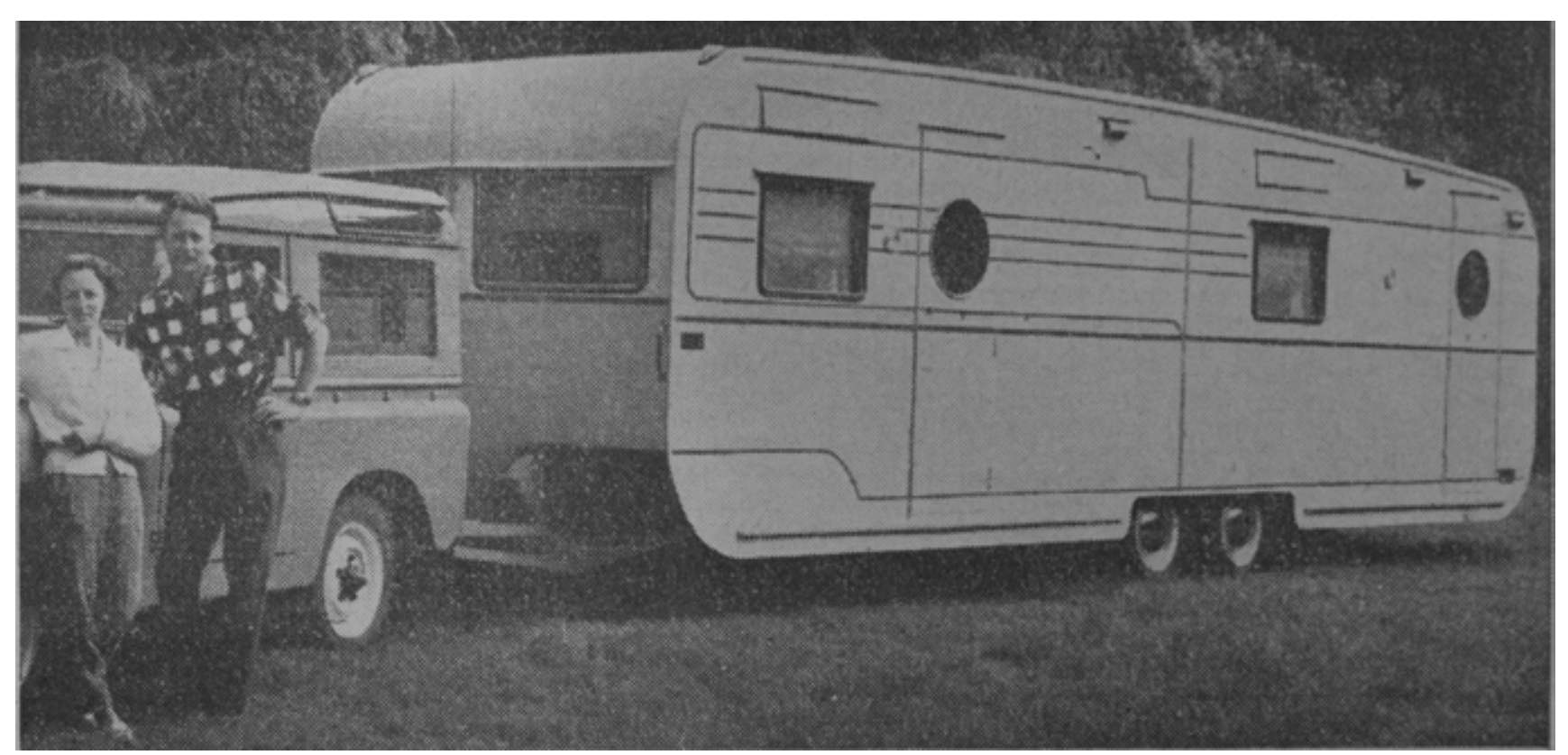

Jean and Ken Bigwood with Landrover and caravan, on assignment for New Zealand in Colour. NZ Motor World, January 1962.

and boat (the law prescribed a total length of 60 feet) from Dunedin to Wanaka through the narrow and winding Cromwell Gorge road was the adventurous highlight of the year for some summer holidaymakers. ${ }^{96}$

The Bigwoods spent Christmas on Coromandel Peninsula where, Jean wrote:

the danger lay not with the narrow track, the steep cliffs dropping away to boulderstrewn beaches, not the ability of our vehicle to negotiate such places, but with the constant possibility of encountering a vehicle coming in the opposite direction. For holidaymakers had now taken to the highways, and the exuberance of the festive season, buoyed-up spirits and bravado urged them into unfamiliar places. ${ }^{97}$

Further north, holidaymakers now safely back in their offices, they drove up Ninety Mile Beach, the caravan 'tracking along in effortless synchronisation', but were forced back over the 'bumps, corrugation 'A three-piece combination seen at Windsor Park, Hastings,' Motor World, December 1961. and potholes' of Northland's 'most notorious road' to reach Cape Reinga. There, a patient wait for the wind to drop enough so that the toetoe flowers did not blur produced what would become their book's cover image.

Patience was essential. Six days of frustration and inactivity were endured beside Lake Ohau before the weather cleared and an archetypal shot of the empty land could be obtained: a single telephone wire and

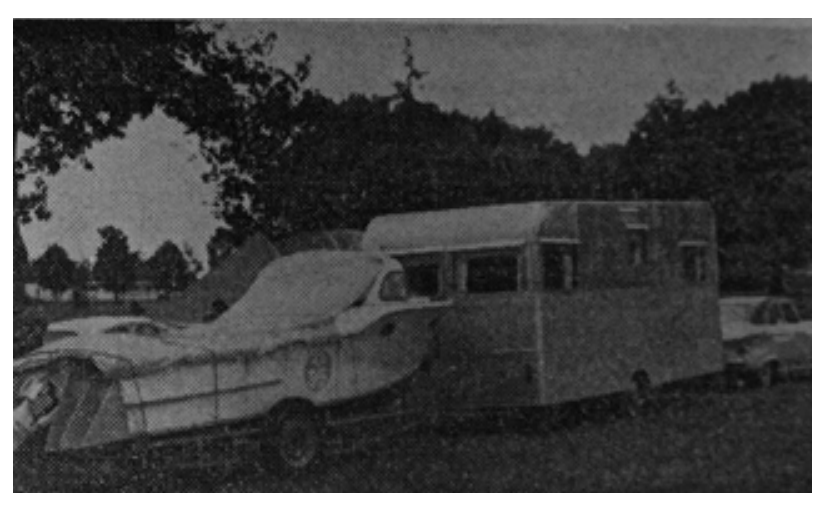

96 Automobile Association, NZ Motor World, December 196r; Campbell Read, personal recollection.

97 Jean Bigwood, 'Man-and-Wife Camera Team', NZ Motor World. 
graded shingle berm hint at connectedness. 'Here you can camp,' wrote Baxter, and 'lay lines for the eels (which taste better than trout if they are first boiled, to remove the fat, and then fried) or perhaps shoot a hare and cook it Maori-style in a pit with hot stones on the lake shore'. ${ }^{8}$ Baxter had spent holidays there as a child, probably doing just that. ${ }^{99}$ Each night the Bigwoods would unload the exposed film from the negative holders - which had to be done in absolute darkness. Their greatest fear was that a car's headlights might light up the darkness and ruin the film. The risks they faced were, in Jean's estimation, mainly technological or a consequence of encounters with other people (cars, roads, and film), rather than an effect of the natural environment. Perhaps this reflects the couple's somewhat reclusive character; yet it is of a piece with the New Zealand Holiday ideal of a beach to oneself.

Jean Bigwood's story hints at a hierarchy of holidaying values, echoed by Holcroft at Otautu Bay when he wrote that less-venturesome travellers are crowding the camping-grounds and boarding-houses at Whitianga and Whangamata, at

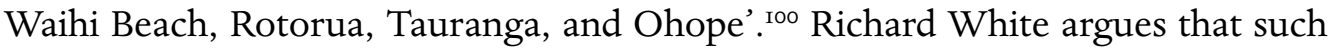
distinctions reflected the need for leisure to remain a way of defining class identity. But Clif Reed seems the most likely of this group to choose to stay in a boarding house. Holidaying might be better understood in terms of adherence to modern or antimodern values. Did what came to be known as 'getting away from it all' or 'going bush'ror acquire authenticity to the extent that it mimicked the pioneer experience?

Free time, not 'ruled by the stiff hand of the clock' in Baxter's phrase, was one of the chief benefits of the holiday, yet among this group, those with sufficient time to focus on the scenery were paid to do so. The Bigwoods spent days - probably weeks - doing nothing in the service of work. Writing about postwar Australian holidays, Richard White finds 'something remarkable: an Anglo-Saxon country that preferred leisure to money-making' ${ }^{102}$ Male New Zealand workers gained a guaranteed two-weeks annual leave before Australians did. But while awards for most Australian workers included three weeks' holiday by the early i96os, in New Zealand this did not happen until 1974 - the year four weeks off became standard for their Australian counterparts. ${ }^{103}$ In an account of the politics of postwar consumer culture that follows the American example set out by Richard Fox and Jackson Lears, Chris Brickell argues that 'the transition from producer to consumer society replaced hard work with pleasure as the primary virtue'. ${ }^{104}$ Although, as Brickell shows, contested ideas about morality and society were at stake, leisure

98 Bigwood and Baxter, New Zealand in Colour, pl 4I.

99 Photograph of James K Baxter as a child, on a pony at 'the Nook, Lake Ohau', 'Photographs of James Baxter, c 1927-c 1968', Baxter family papers, MS-0975/234, Hocken.

Ioo Holcroft and Bigwood, New Zealand, I4; Richard White, On Holidays: A History of Getting Away in Australia (Melbourne: Pluto Press Australia, 2005), 90-96.

IoI Ross, Going Bush; Lears, No Place of Grace, I59-60, 30I-307.

I02 White, On Holidays, 90-96.

I03 Ibid, I2I-I29; Trade Union History Project, Workers' Holidays in New Zealand, 22.

I04 Chris Brickell, 'The Politics of Post-War Consumer Culture', NZJH 40:2 (2006), I44. 


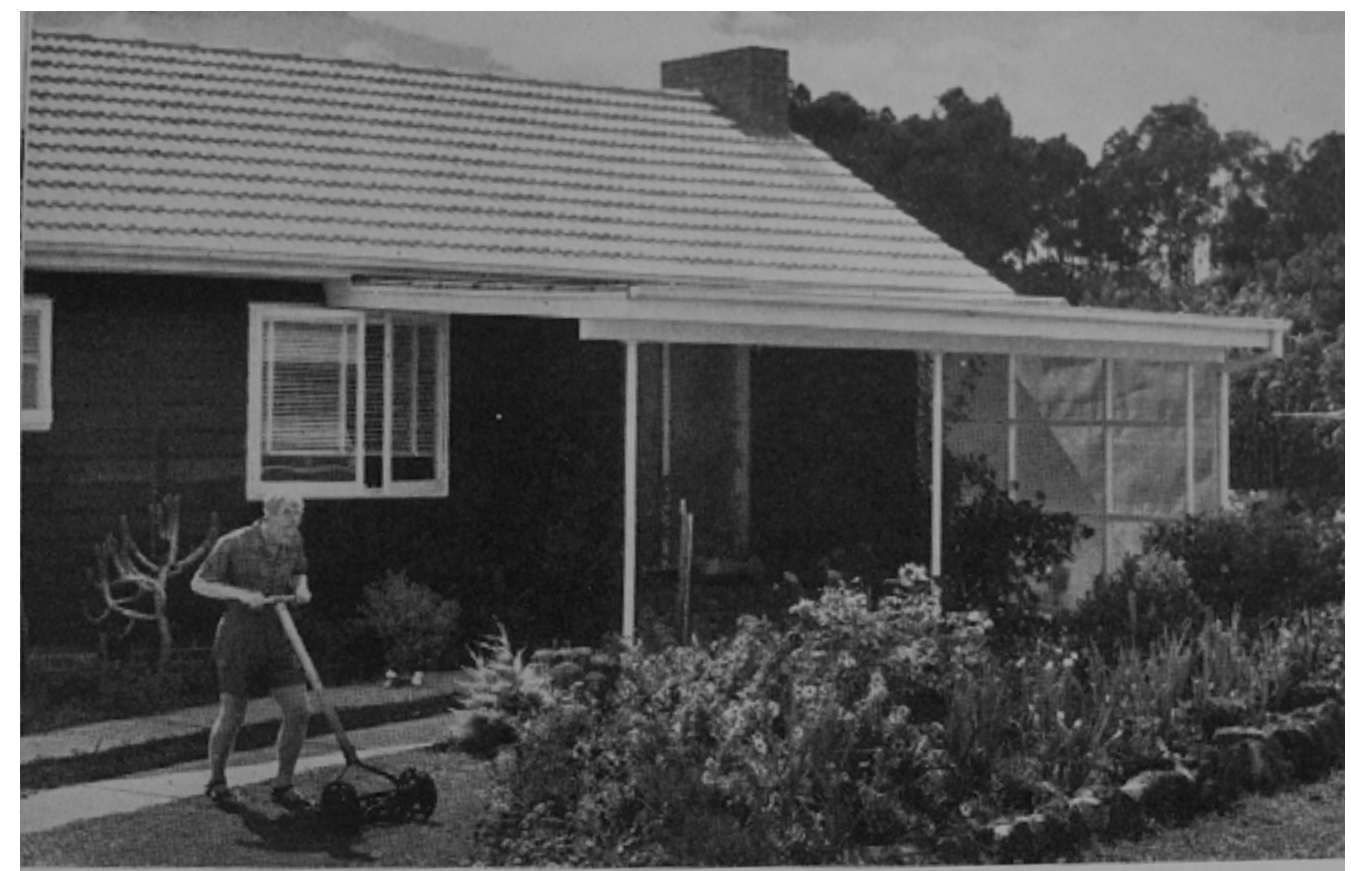

did not mean doing nothing. Weekends, the major source of free time, were filled with sport, gardening, concreting, sewing, baking, preserving, washing cars, and then, the 'Sunday driving parade'. A photograph of this 'feature of New Zealand weekend life', at the Byrd Memorial on Wellington's Mt Victoria, was planned for inclusion in New Zealand. ${ }^{105}$ (Fine weather was required, however, which may explain why this image does not appear in the book.) Something of the strangeness of the idea of idleness, for Pakeha, was suggested by Susan Graham in 1962: 'one of the true benisons which the Maori has to offer the Pakeha is his mastery of the art of relaxation'. ${ }^{\text {106 }}$

It cannot be claimed that the holidays described here are representative, but one common characteristic stands out: travelling with family, or to visit family, or both. As Richard White writes, about Australia, during the postwar decades the holiday "became a permanent symbol of the new "way of life" that was being constructed around the family, home ownership and car culture'. ${ }^{107}$ It was a way of life that also found a home in New Zealand.
'Lawn-mowers make week-end music for home-proud Aucklanders, with gardens trim and bright with flowers'. New Zealand Holiday Horizons (1958), 48.

I05 Don Sinclair, summary of discussion with Holcroft and Bigwoods, 2 July I963, A H \& A W 


\section{At home on every roaded mile of New Zealand}

In stark comparison to Neil Atkinson's account of pre-war holidaying, when II,000 people departed from Wellington Railway Station on Christmas Eve 1938, aboard I6 trains, the Baxters, Bigwoods, Reeds, and Shadbolts travelled by car. ${ }^{108}$ In I940, and again in 1955, Oliver Duff noticed something strange:

It has been a quite astonishing fact that the industrial penetration of the United States has created no excitement. We have seen huge assembly works established by motor-car manufacturers, bought and used the cars, worked in our thousands in the factories themselves, and thought very little about the situation although it was so obviously the arrival of a new industrial era. ${ }^{\text {I09 }}$

One of the few to treat the social impact of the motor car seriously was Monte Holcroft, a lifelong non-driver. Holcroft expressed a distrust of the car in his 1946 essay The Deepening Stream, where it symbolised what Smithies calls 'his antimodern antipathy towards mechanization and commercial capitalism'. ${ }^{\text {Iо }}$ This stance also colours Holcroft's claim, in 1979's Carapace, that the car and the movie were the two technologies with the greatest impact on the twentieth century. ${ }^{\text {III }}$

When, in 1936, Minister of Public Works Bob Semple promised to bring 'the natural beauties of our country . . . within easy reach of all of our citizens', he meant by rail. ${ }^{I 2}$ Although Semple also built roads, and Duff thought he would be remembered as 'the man who lifted us out of the mud', ${ }^{\text {II3 }}$ work on Semple's Centennial Highway project, running north from Wellington to Paekakariki, was interrupted by the Second World War. When it finally opened in 1950, the section from Johnsonville to Tawa was billed as the country's first motorway.

The I950s National government favoured road building over public transport provision and embarked on a sustained programme of motorway construction. Former roading contractor Stan Goosman held nearly all significant infrastructural portfolios concurrently in the early I950s including Railways, Works, Transport and, until 1953, Housing Construction'. ${ }^{114}$ Auckland's first 3.2 kilometres of motorway between between Penrose and Mt Wellington opened in 1953. By 1965 it reached 23.4 kilometres south to Drury. Although the total length of roads in New Zealand increased only slightly between 1940 and 1963, from 53,086 to 57,I35 miles, quality improved significantly. State highways lengthened from 3990 to 7059 miles and the proportion of sealed road rose from io per cent in I 940 ( 5345 of 53,086

I08 Atkinson, 'Call of the Beaches', Journal Of Transport History, 17. The Pascoes purchased a Humber 90, brand new, in 1963: Maclean, John Pascoe, 269.

Io9 Duff, New Zealand Now, ir8.

IIo Smithies, 'An Antimodern Manqué', NZJH 40:2, I86.

III Monte Holcroft, Carapace: The Motor Car in New Zealand: A Roadside View (Dunedin: John McIndoe, 1979).

II2 Public Works Statement, AJHR (I936), D-I, pp. ii, xi. in Atkinson, I6.

II3 Duff, New Zealand Now, i6.

II4 Christopher Harris, 'Slow Train Coming: The New Zealand State Changes its Mind about Auckland Transit, 1949-56', Urban Policy and Research 23:I (2005), 44. 


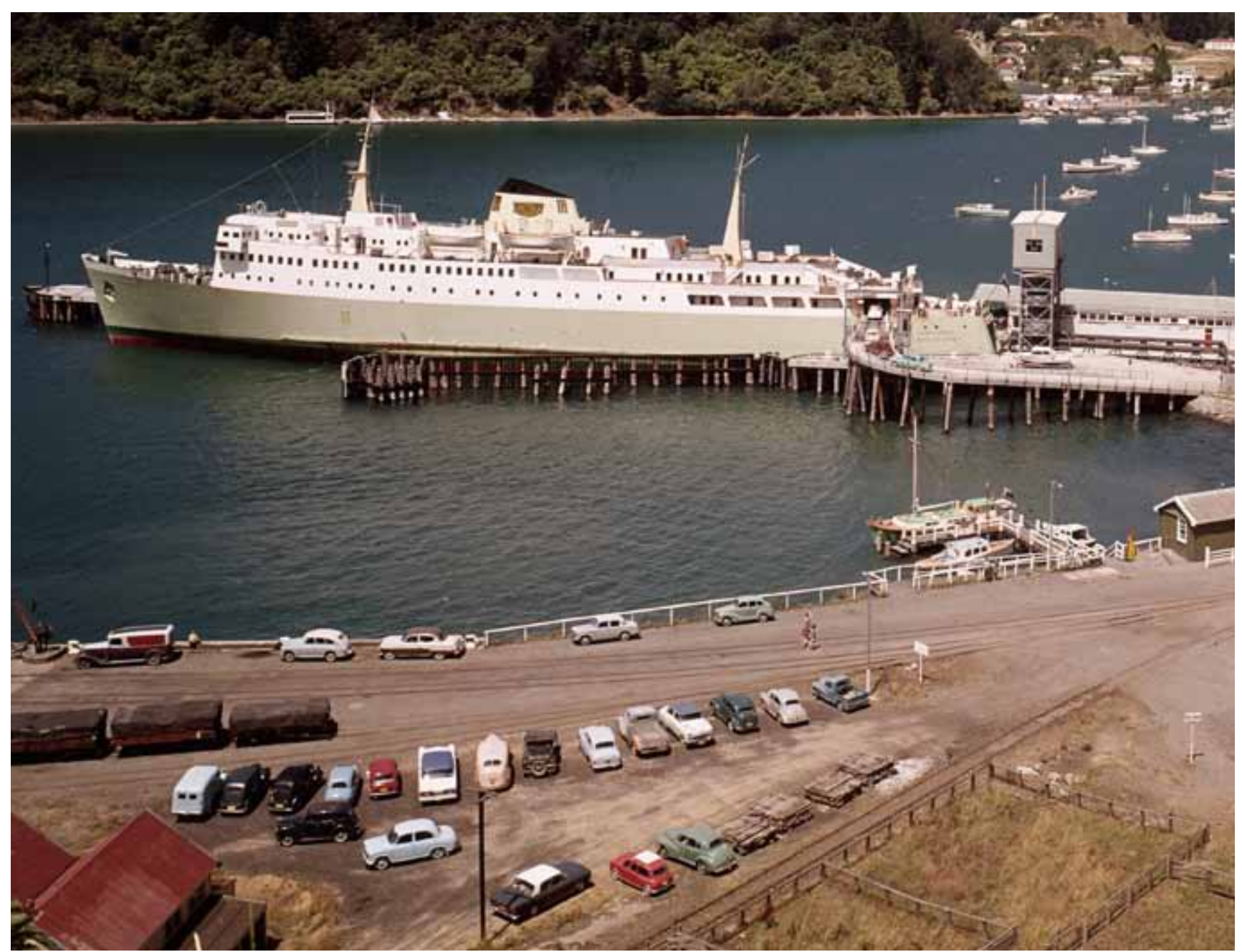

Detail of 'Aramoana at

miles) to 3I per cent in I963 (I7,790 of 57,I35 miles). ${ }^{\mathrm{II} 5}$ Before the Aramoana came into Picton'. Gladys Goodall, GG-10-0065-1, ATL. http://natlib.govt.nz/ service in August 1962, vehicles crossing Cook Strait had to be loaded and unloaded records/23101966. by crane. The "roll-on, roll-off" ferry effectively created a road from one end of New Zealand to the other. Even the remotest parts of the country became accessible by car. Notably, the last major new highways constructed, the road to Milford Sound, completed in 1953, and the road over the Haast Pass between Wanaka and South Westland that opened in 1965 , were built chiefly for the use of tourists and holidaymakers. ${ }^{\mathrm{I} 6}$

When Duff wrote that industrialisation had created no excitement, he was not describing its products. Over just three days in March 1949, I48,704 people visited Ford showrooms around the country to see the new Forty-Niner model. ${ }^{\mathrm{II}}$

II5 KW D Balfour and Victoria University of Wellington, The Administrative Problems of Coping with Road Traffic Congestion in New Zealand: A Group Project (Wellington: School of Public Administration, Victoria University of Wellington, 1964), I7.

II6 James Watson, Links: A History of Transport and New Zealand Society (Wellington: Ministry of Transport, 1996), 199, 243; John Pascoe, The Haast Is in South Westland (Wellington: A H \& A W Reed, I966).

II7 Graham Hawkes, On the Road: The Car in New Zealand (Wellington: GP Books, 1990), 68. 


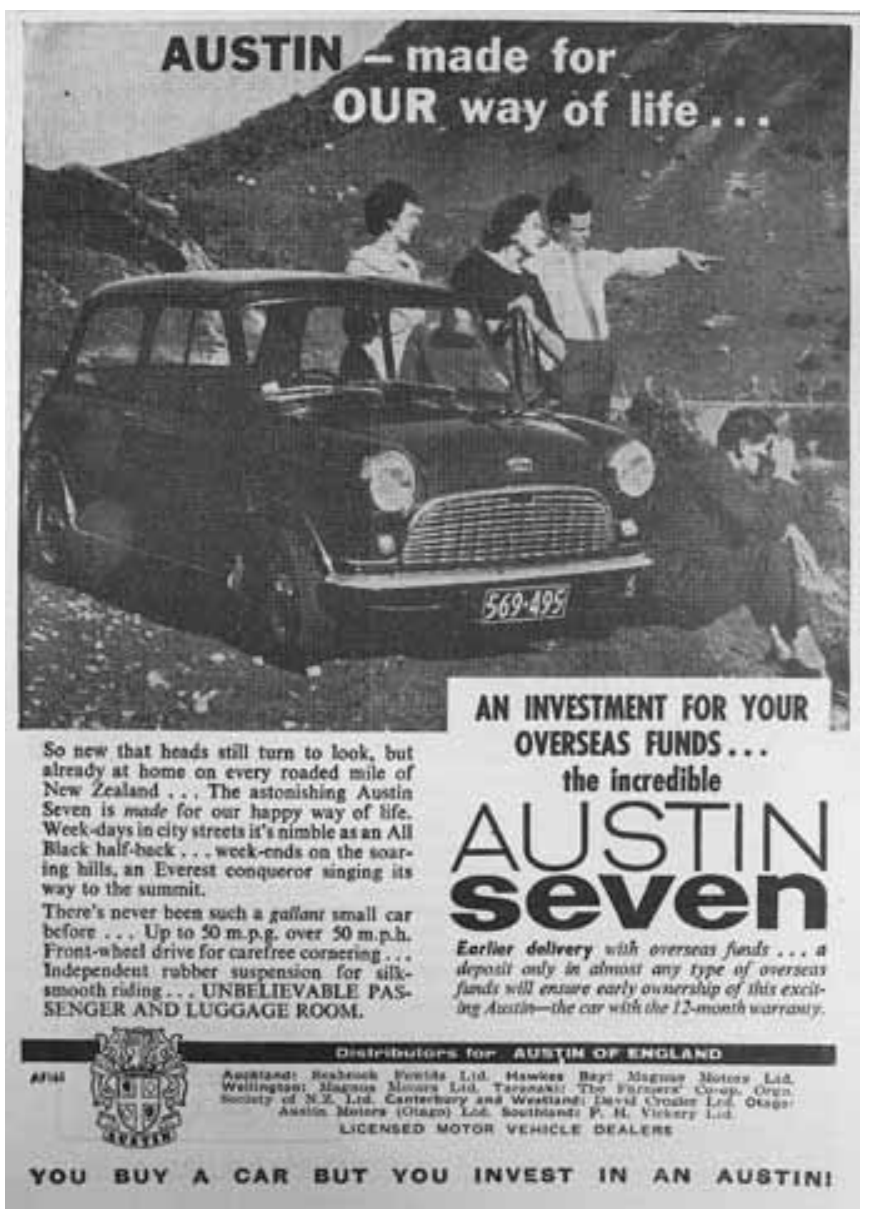

'Austin - Made for OUR Way of Life', NZ Motor World, January 1962.
There were 235,000 cars on the road in 1950, 505,000 in 1960 and 634,000 in 1964 . In that year, road travel made up 93.5 per cent of all passenger traffic and the road transport sector comprised II.5 per cent of the workforce. Annual petrol consumption more than doubled between 1950 and 1963 , from 146 million to 317 million gallons. Between 1950 and 1964 , the ratio of cars to people moved from 1:7.8 to $1: 4.2{ }^{\mathrm{II} 8} \mathrm{~A}$ more useful way to interpret these numbers is that by 1960 the number of cars reached equivalence with the number of households. ${ }^{\text {II }}$

The car is often portrayed as an embodiment of particular ideals - Graham Hawkes itemises 'mobility, freedom, status, sexuality and fun'. ${ }^{220}$ But this is far from a complete list. The Austin Seven advertised in Motor World in 1962 promised to turn heads and give carefree cornering and silksmooth riding. But it was also, more soberly and prominently, 'made for OUR way of life', 'an investment', and 'already at home on every roaded mile of New Zealand'. And while Hawkes emphasises the 'incalculable' impact on the young men of provincial New Zealand of the outrageously curved lines of the 196I Ford Consul 315, he does so shortly after acknowledging that, in the early I960s, 'advertising was heavily family-orientated and overwhelmingly paternalistic, with "father" undoubtedly the decision-maker in the family women were invariably decorative. ${ }^{\text {I2r }}$

\section{Domesticated pioneers}

In important ways, the photograph opposite encapsulates the main strands of the discussion in this chapter. Here is the Pakeha man, surrounded by women and children, on holiday at the beach. A motorcar is nearby, and he holds a camera in his hands to photograph scenes from nature. In the I950s and I960s, the idealisation of

II8 Balfour, Coping with Road Traffic Congestion, 3-4.

II9 Vince Dravitzki, Tiffany Lester, 'Some Interesting Old Transport Data And Where To Find It', Opus International Consultants, Lower Hutt, sec 2, http: / / www.opus.co.nz / frstweb / co2 / Some $\% 2$ ointeresting\%2oold\%2otransport\%2odata\%2oand\%2owhere $\% 20$ to $\% 2$ ofind\%2oit.pdf. I20 Hawkes, On the Road, 7.

I2I Ibid, IO3-IO4. 


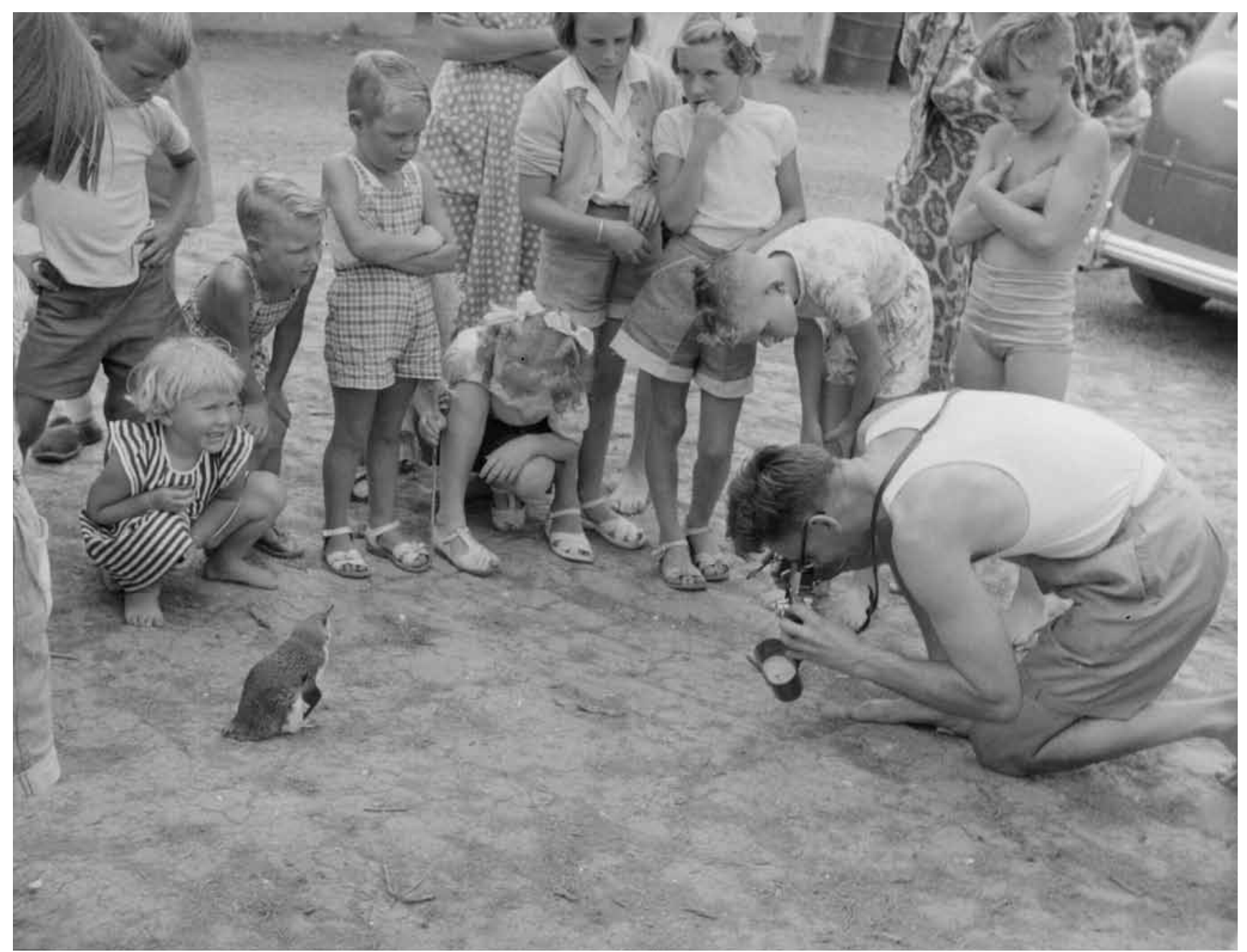

Unidentified man taking a photograph of a penguin at the Motor Camp, Paihia, Bay of Islands. January 1955.

Whites Aviation Ltd . Ref:WA-37173-F. ATL. http://natlib.govt.nz/records/23529120.

home and family was ubiquitous and enduring. ${ }^{\mathrm{I} 22}$ The year New Zealand in Colour was published, 196I, was the most fertile of the baby boom: more than 65,000 babies were born. ${ }^{123}$ Family, it was understood, was the foundation of the suburban New Zealand "way of life". That phrase, while widely used, hardly described a culture unique to New Zealand. Mark Rolfe points out that it was identified with conservative politics, and 'accommodated US cultural transmission'. ${ }^{124}$ When Susan Graham wrote in the early i96os about visiting Tokoroa and Kawerau, she called them cities 'of the future being forged in the present', 'new, bare, lusty, brash',

I22 For example Bronwyn Labrum, 'The Changing Meanings and Practices of Welfare, I840sI990s', in Giselle Byrnes, ed, The New Oxford History of New Zealand, 408-4II; on the family holiday see Ross, Going Bush, I49-155.

I23 'I96I - key events', New Zealand History Online, http://www.nzhistory.net.nz/culture/ the-1960s/I96I-key-events.

I24 Mark Rolfe, 'Faraway Fordism: The Americanization of Australia and New Zealand During the I950s and I960s', NZJH 33:I (1999), 73-74. See too Richard White, 'The Australian Way of Life', Historical Studies 18:73 (1979), 528-545. 
and with schools 'like junior branches of the United Nations'. In that new world, Graham noted that American workers liked to 'import a good deal of merchandise from their homeland in order to enjoy a familiar way of life. ${ }^{\text {'25 }}$ The way of life was intrinsic to consumerism. As its use in the advertisement opposite shows, it was available for purchase.

Ian Brailsford has noted that a transition 'from domestic thriftiness to purchased affluence' occurred in the I950s and I960s. But he also suggests that, even by the early I960s, New Zealand consumers were thought to be somewhat unpracticed and unskilled. ${ }^{126}$ The problem of the tourist, and the uses of the coffee table book discussed in the next chapter, show that this transition was not always smooth. Called on to describe the New Zealander in 1957, Hugh Hanning thought of him as:

an unwearying father. He will expend endless time and phenomenal ingenuity on fixing up toys for his children out of the most unpromising material, from beer crates to derelict pieces of metal airstrip. It is when doing this that he is most truly himself - the domesticated pioneer - and hence one suspects most truly happy. ${ }^{\mathrm{I} 7}$

The consumer way of life was an attitude of life, in John Berger's phrase, that Pakeha were still trying on for size. Perhaps the success of the New Zealand pictorials was due to the apparently effortless manner in which an idea of nation - a New Zealand family of man - appeared out of the new modernity of photography, holidays, and cars.

I25 Graham, This Land I Love, 68-72.

I26 Ian Brailsford, “"Enlightened Buying”: From Consumer Service to the Consumers' Institute, I959-1964’, NZJH 4I:2 (2007), I23-I24.

I27 Hanning, 'Farmer fighter and family man', New Zealand Holiday 5 (I957), I4. 


\section{Movement Inward: the Gift of the Colour Pictorial}

\section{Introduction}

In his study of exchange, material culture, and colonisation, Nicholas Thomas writes that there is 'great scope for analysis of the appropriation of things as objectifications of local or national identity-projects in the south Pacific'. ${ }^{\text {I From the }}$ historian's perspective, Thomas's argument that such examinations of exchange and culture need to be located within particular historical contexts is unexceptional. Recent critiques of New Zealand history that have set out the limits to the historical identity-narrative, and advanced alternative interpretive avenues, make the proposition that colour pictorial books titled New Zealand are well suited to analysis as a Pakeha "identity-project" more difficult to sustain. A decade ago Peter Gibbons argued, first, that the national-identity formulation served to obscure the ongoing effects of colonisation, and then that the nation-as-subject needed to be decentred or even dissolved in favour of macrohistories of production, trade and consumption, or microhistories of individuals, households and neighbourhoods. This study is perhaps more a microhistory of objects, but I am indebted to another of Gibbons's suggestions, to engage with the development of consumerism and consequent shifts in behaviour and personal expectations, as well as to Chris Brickell's work on postwar consumer culture. ${ }^{2}$ It is within this context that I hope to show how the appropriation - and circulation - of things helped to create an objectification of New Zealand. Analysis of these processes can help to decentre the nation, while also showing the importance of global relationships, interactions, and transactions to the development of national ideas. The national-identity formulation (first seriously advanced in Keith Sinclair's 1959 History of New Zealand but

\footnotetext{
I Nicholas Thomas, Entangled Objects: Exchange, Material Culture, and Colonialism in the Pacific (Cambridge, Mass: Harvard University Press, I991), 25-26.

2 Peter Gibbons, 'Cultural Colonization and National Identity', NZJH 36, I, (2002): 5-I7; Peter Gibbons, 'The Far Side of the Search for Identity: Reconsidering New Zealand History', NZJH 37, I (2003): 38-49; Chris Brickell, 'The Politics of Post-War Consumer Culture', NZJH 40, 2 (2006): I33-155; Tony Ballantyne, Webs of Empire: Locating New Zealand's Colonial Past (Wellington: Bridget Williams Books, 20I2), ch I2, conclusion.
} 
strikingly absent from the colour pictorials) also seems to have obscured the extent to which the nation has been a product of modernisation.

I begin by examining the category to which the pictorial books have often been said to belong: the coffee table book. The term lacks either a precise definition or an exact origin. It was (and is) neither universally nor consistently used. Yet it usefully describes, even if only by implication, a social and aesthetic role of public display for a book within the domesticated, privatised space of the mid-century living room. A second line of inquiry reprises the earlier discussion of the gift book to suggest that, when thinking about 'how to do things with books', in Leah Price's memorable phrase, the relationship of greatest relevance was not that between publisher and bookseller, or between bookseller and purchaser, or even author and reader. ${ }^{3}$ More interesting are the social relations implicit in Pakeha New Zealanders' gifts of these de luxe books to each other and to friends and family overseas. Arjun Appadurai argues that luxury goods are those 'whose principal use is rhetorical and social, goods that are simply incarnated signs'. ${ }^{4}$ An examination of the New Zealand pictorial book's suitability as both luxury good and gift shows Pakeha negotiating their participation in modernity. The "New Zealand" coffee table book was displayed in the home, intimately and unmistakably modern, a match for and active participant in a postwar internationalism that was beginning to flourish beyond the old ideas of empire.

The interiorisation of experience is a phenomenon many historians have observed as an effect of modernity. It was intensified by the postwar consumerism in a manner described, for example, by Kristin Ross as a 'movement inward'. ${ }^{5} \mathrm{New}$ Zealanders, too, were increasingly enclosed within home, family, and motor car. The success of the New Zealand pictorial book was also evidence of this tendency, but the New Zealand it reproduced was an antidote rather than a paen to modernisation. The books were a continuation of a narrative that idealised a restorative idyll, and thus were objects of modernity that carried a profoundly anti-modern message. The Pakeha New Zealand of the coffee table was an expression of constant negotiation between these modern and anti-modern impulses. It was not enough to be at home in New Zealand; whether in Wellington, Sydney, London, Cape Town, or San Francisco one had also to be able to be at home with New Zealand.

3 Leah Price, How to Do Things with Books in Victorian Britain (Princeton: Princeton University Press, 20I2).

4 Arjun Appadurai, 'Introduction: Commodities and the Politics of Value', The Social Life of

Things Commodities in Cultural Perspective (Cambridge: Cambridge University Press, 1986), 38.

5 Describing modernisation in France between 1955 and 1965, Kirstin Ross identifies 'the move-

ment inward' as being: 'echoed on the level of everyday life by the withdrawal of the new middle classes to their newly comfortable domestic interiors, to the electric kitchens, to the enclosure of private automobiles, to the interior of a new vision of conjugality and an ideology of happiness built around the new unit of middle-class consumption, the couple' (Kristin Ross, Fast Cars, Clean Bodies: Decolonization and the Reordering of French Culture (Cambridge, Mass: MIT Press, 1995), II. 


\section{Coffee, table, book}

In 1966, Reeds production manager Don Sinclair returned from a lengthy and exhausting trip to Japan, where he had discussed arrangements for printing the company's colour books. Relaxing after the journey, he wrote to Monte Holcroft:

It was a pleasant experience, therefore, to hoist New Zealand from the shelf again

... while in a relaxed and receptive state. Propped on two pillows across the knees

I found the present volume manageable without descending to the coffee table! ${ }^{6}$

There is a deprecating humour at work, entirely lacking in scorn, which imparts a lingering sense that the coffee table book is culturally if not physically lightweight. This has been a lasting perception. By entering the search terms "coffee table book" and "jstor" into Google you will be able to read a great many variations on this theme: 'a first impression may cause it to dismissed as a "mere" coffee-table book. But that would be unjust' ${ }^{7}$ The coffee table book is defined as a non-thing, an absence to which the object actually under consideration may be compared.

What is routinely ignored in such statements is any sense that the books might be revealing of particular social relations. This weight of absence suggests a distinctive relationship with materiality in which, quantified as value, weight operates as a social judgement rather than physical measurement. In this sort of thinking, the object itself remains pivotal. Arjun Appadurai argues that:

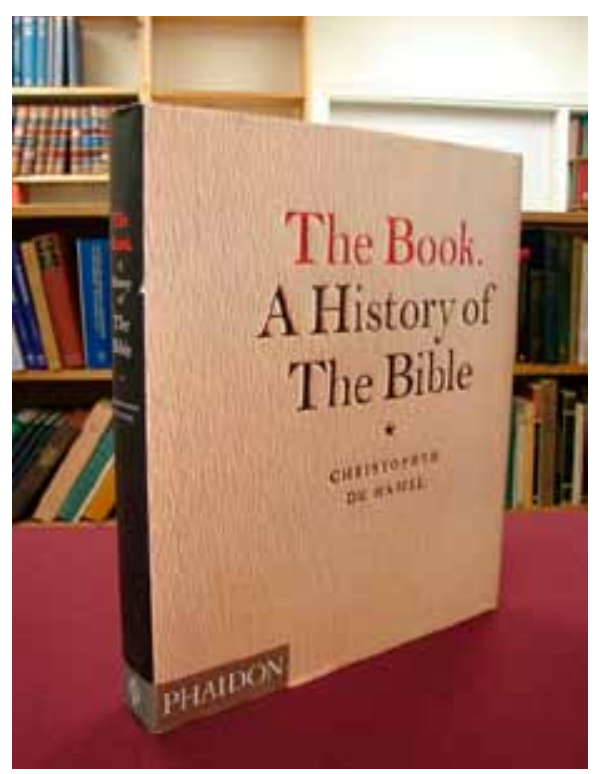

The Book: Not a coffee table book.

their meanings are inscribed in their forms, their uses, their trajectories. It is only through the analysis of these trajectories that we can interpret the human transactions and calculations that enliven things. Thus, even though from a theoretical point of view human actors encode things with significance, from a methodological point of view it is the things-in-motion that illuminate their human and social context. $^{8}$

Bill Brown writes that it is necessary to ask what work an object performs in order to show how it can 'organize our private and public affection', while also claiming it is the subject's desire rather than productive labour that is the source of an object's value. It was Walter Benjamin, he says, who 'recognized that the gap between the function of objects and the desires congealed there became clear only when those objects became outmoded'. ${ }^{9}$ I suppose the very existence of this study tends to confirm Benjamin's thesis. Undoubtedly, the somewhat disparaging connotations that attach to the coffee table book imply more than that they were produced,

6 Don Sinclair to Monte Holcroft, 23 July 1966, Holcroft papers, correspondence: Shaw-Swan, 1942-I967, Ms-papers-II86-23, ATL.

7 J K Elliott, review of The Book: A History of the Bible, by Christopher de Hamel, Novum Testamentum 45:2 (April 2003), 198-200, http:/ / www.jstor.org/stable/ I56IoI9.

8 Appadurai, The Social Life of Things, 5.

9 Bill Brown, ed, Things (Chicago: University of Chicago Press, 2004), 7, I3. 
Note the can of ham on the coffee table. Richard Hamilton, 'Just what is it that makes today's homes so different, so appealing?' 1956 , collage, $260 \mathrm{~mm}$ $\times 248 \mathrm{~mm}$, Kunsthalle Tübingen, Germany.

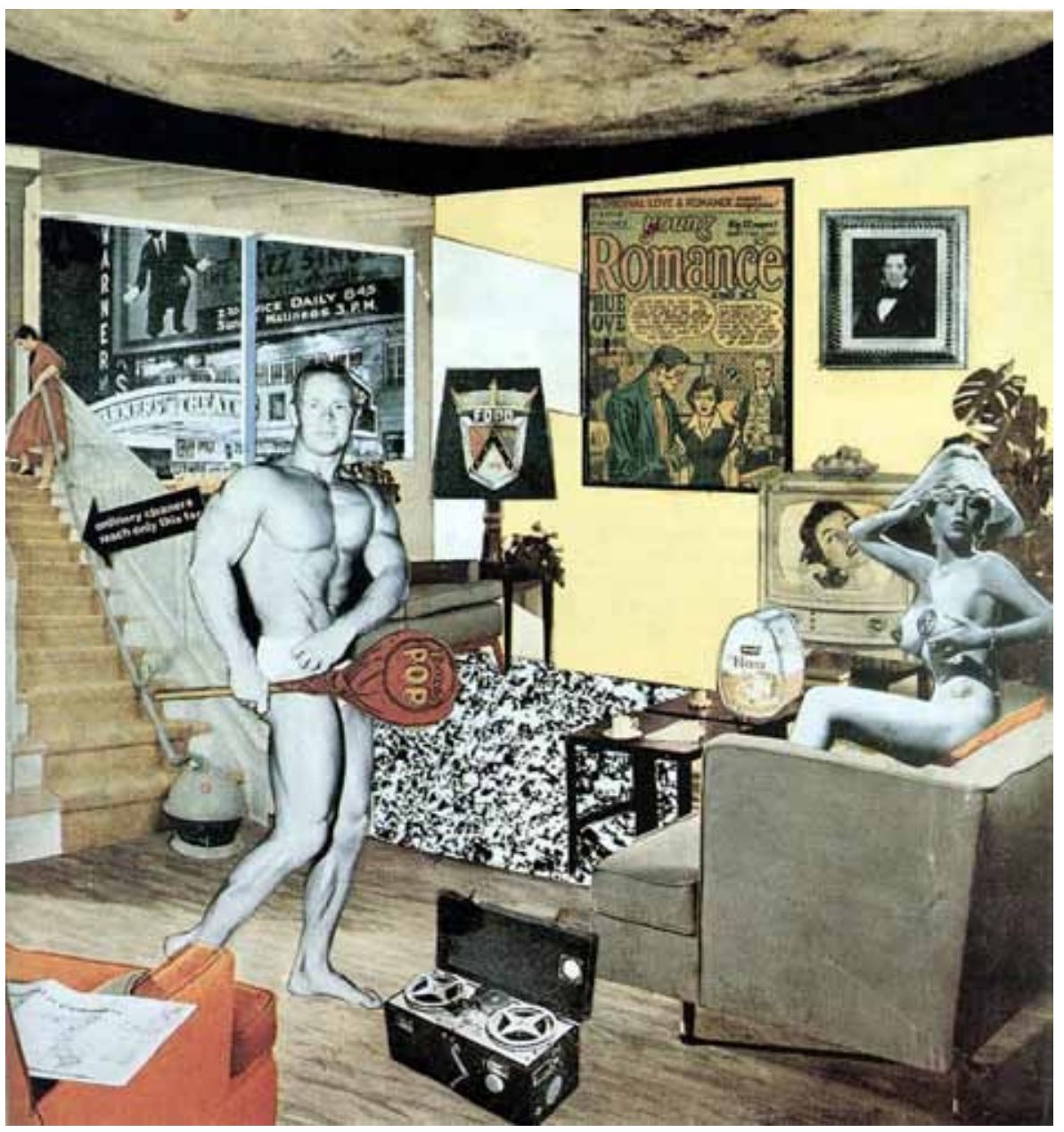

and bought, for purposes other than reading. Their performative organisation of affection can be seen at work, to take another example, in Richard Hamilton's 1956 utopia of capitalist spectacle.

Sinclair's reference to the coffee table was one of very few made by Reeds staff or authors. In editorial discussions the preferred term was simply 'colour pictorial'; the company's publicity used 'presentation volume' or 'gift book', terms that will be explored later in this chapter. Why then choose it for particular attention? To argue that it is the term most familiar today, while pointing out that it was also in use in 1966, is not simply making a claim of presentism. It is rather to indicate, initially, a shared activity of looking while in 'a relaxed and receptive state'. In addition, understanding the descent to the coffee table is necessary to a fuller understanding of the uses to which the books were put.

The term "coffee table book" conflates three things in one, giving it particular social and cultural resonance. First, there is coffee. Jeffrey Schnapp points out a key historical fact: in Western societies until well into the twentieth century, public consumption of coffee was the norm, and the places where coffee was drunk were: 
associated with novelty and news, with present-centred, 'modern' activities like the reading of newspapers, with commerce, advertising, the promiscuous mixing of social classes. ${ }^{\text {IO }}$

In New Zealand, cafés which sold coffee, in contrast to the more traditional tea room, only began to proliferate in the I950s. They looked 'pseudo-European', stayed open late, played jazz records, and attracted the fashionable, the sophisticated and the artistic. The first 'really stylish' café in Wellington was run by Harry Seresin, a refugee from Nazism, in the city's first modernist office building, Massey House, designed by the architect Ernst Plischke who had also emigrated after the Nazi occupation of Austria in 1938. ${ }^{\text {II }}$ Seresin sold his beverages on a mezzanine floor above Parsons Bookshop. Coffee was cosmopolitan. In Dunedin, Gregg's began producing instant coffee in the early I960s, thus combining advanced technology and labour-saving convenience with upwardly mobile aspiration. ${ }^{12}$ Coffee, as the New Zealand Woman's Weekly announced on the cover of its edition of 27 March, 196I, was a 'New Way Of Life In New Zealand'. Alongside eight pages on contemporary New Zealand art were ten pages about coffee. Instant coffee was 'no longer a freak' but 'big business'. Just a few years earlier, 'considerate hostesses were inclined to apologise for serving it, and before that it was "just another of those American inventions"', The total amount of coffee imported into New Zealand annually had increased in five years from one to four million pounds and Auckland's 'Continental-style' coffee houses numbered around roo compared with perhaps half a dozen a decade earlier - 'the glamour of their "atmosphere"-laden presences rather startling in contrast to the more staid, conventional tearooms' ${ }^{\text {I3 }}$

'Like a many-tributaried river, coffee has spread around the world,' the Weekly enthused and, made with percolators, dripolators, vaculators, or even just in an earthenware jug, it was now being drunk in the home throughout the country. For guests, coffee would be brought to the coffee table, positioned next to the hostess's armchair, and served with copious whipped cream and a selection of liqueurs. The coffee table, while situated in a space of private leisure and relaxation, allowed the world to flow into the home. ${ }^{\mathrm{I}}$ While in function it echoed the tea table, which was located above and behind the armchair, the coffee table was low and placed before or to the side of comfortable armchairs in a lounge or living room, thus encouraging informal conversation and sociability. The Weekly pointed out that this allowed the hostess to serve her guests while sitting among them, which suggests a position

\footnotetext{
Io Jeffrey Schnapp, 'The Romance of Caffeine and Aluminum', in Brown, ed, Things, 307.

II 'Wellington cafe culture', New Zealand History Online, Ministry for Culture and Heritage, www.nzhistory.net.nz/ culture/ the-daily-grind-wellington-cafe-culture-1920-2000, updated 20 December 2012.

I2 Anthony Wild, Coffee: A Dark History (New York: WW Norton, 2005), 204-205; 'Coffee Gregg's', www.greggs.co.nz/coffee.

I3 'Instant Coffee is Now Big Business', New Zealand Women's Weekly, 27 March 196I, Io-II; Auckland City Art Gallery and Newstalk izB 1950's Show, New Zealand Home \& Building: The Newstalk 1ZB 1950s Show, Auckland City Art Gallery, Souvenir ed (Auckland: Robin Beckett, 1992), 45

I4 'Coffee New Way of Life in New Zealand', New Zealand Women's Weekly, 27 March I96I, 50-5I.
} 


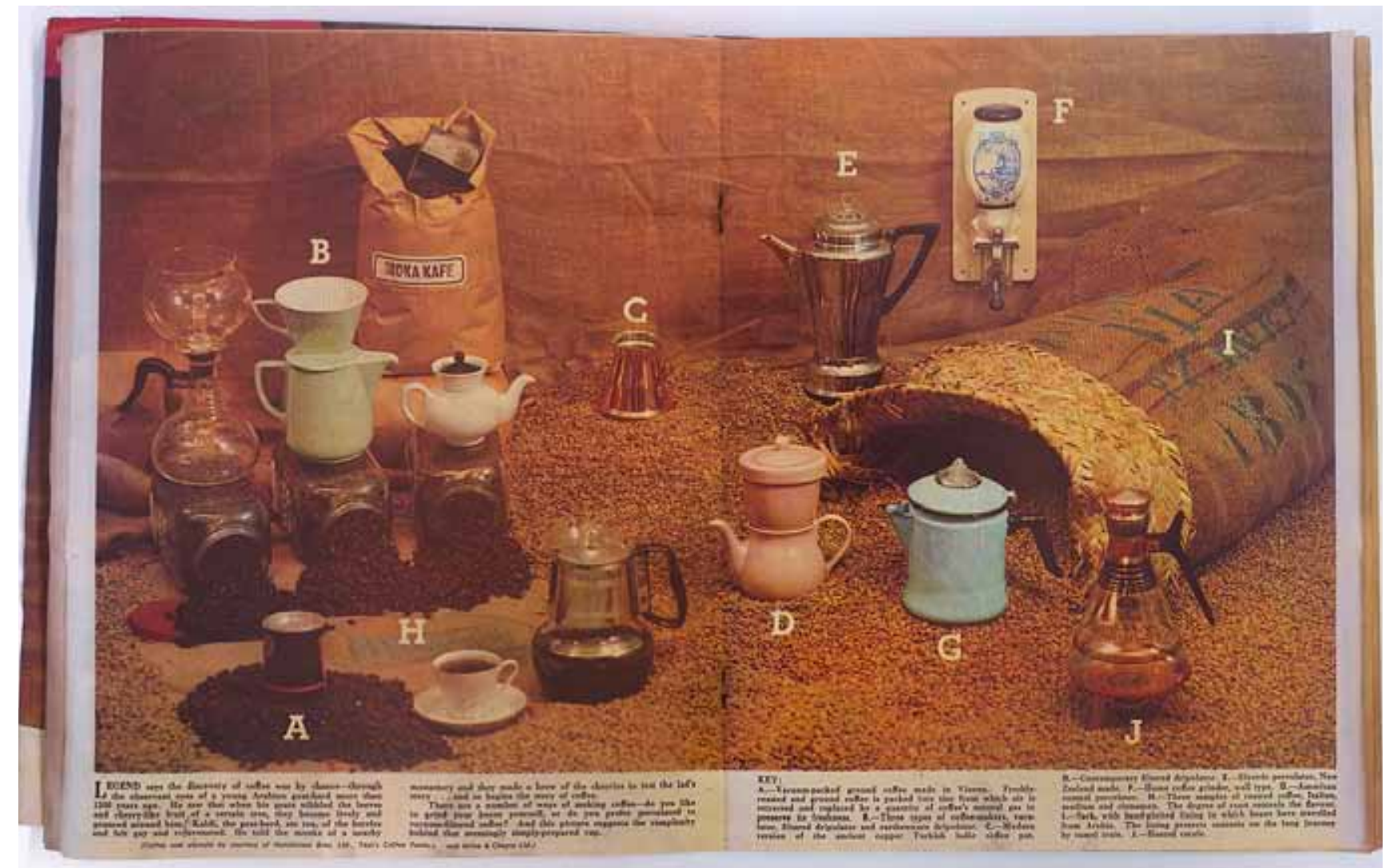

Spread from New Zealand Woman's Weekly, 27 March 1961, showing coffee equipment for the home. of greater equality (and something of the reciprocal nature of the gift) than was possible with service from a trolley or table above. The historian of mid-century design Adrian Franklin writes that it was 'the one item of furniture that is completely modern'; nothing like it had existed before the first designs appeared in the I920s and they became an essential element of domestic Western furniture from the i950s. (Indeed Franklin claims most supposedly antique low tables had their legs shortened once the coffee table became popular. $)^{15}$

While Franklin's origin is modernist (Mies van der Rohe, among others, designed them), Witold Rybczynski finds them in the eighteenth century English country house. In what Rybczynski says was a 'landmark moment in the evolution of domestic comfort', sofas were placed at right angles to the walls and 'low tables - the first coffee tables - were arranged in front'. This change contributed to a developing informality of both manners and room arrangement, and was associated with the house becoming a place of leisure rather than work, in which the privacy of the family should be disturbed as little as possible. ${ }^{6}$ (Incidentally, as Rybczynski points out, it was also at this time that the Romantic enthusiasm for nature brought cut flowers and pot plants inside.) The appeal of the Georgian interior, he says, has lasted because it expresses the idea that comfort includes visual delight, physical well-being and usefulness. ${ }^{17}$

I5 Adrian Franklin, Retro: A Guide to the Mid-2oth Century Design Revival (Sydney: University of New South Wales Press, 20II), 45-47.

I6 Witold Rybczynski, Home: A Short History of an Idea (New York: Viking, 1986), I07-Io8.

I7 Ibid, II8, I20. 
Perhaps the success of the coffee table was due to the combination two ideas, modernity and comfort, which were not always regarded as compatible. Whim Wham mocked government architect Gordon Wilson's 1954 hope that the home of the future would be 'more scientific', comparing cosmopolitans:

They take 'Homes and Gardens', they cultivate Cactuses,

They engage in French cooking and similar practices;

Their Furnishings, cut to the fashionable minima,

Are such as beglamour the Cruiseship or Cinema;

with 'Dwellers in Boxes of Brick':

With their Prison-size Windows and Curtains of Lace,

Their Catacomb Hallways, their Murder of Space,

Their Cellular Rooms, their Upholstery sordid,

Where the Spirit is stifled, the Eye unrewarded.

Unsurprisingly, perhaps, the latter group were:

So handsome, so happy, it sometimes appears,

As if Art were undreamt-of, Design non-existent! ${ }^{18}$

It was an American and specifically Californian take on modernism that flourished, emphasising ease and informality while sharing the cosmopolitan heritage of the café. This, according to Rybczynski, was 'a "Free World" style, representing democracy and America in the Cold War' and a 'morally unblemished ... break with the past'. ${ }^{19}$ The parallels with the worldwide success of the Family of Man coffee table book are unmistakable. In an article in the American Everywoman's Magazine in I947, the coffee table was said to be 'the heart, soul and center of a home' and the one piece of furniture on which a housewife might 'splurge'. ${ }^{20}$ Talk of heart and soul hardly prompts ideas of stripped-down functionalism. The American influence would seem to suggest rather the long-standing appeal of what Rybczynski calls the 'domestic engineers' of the nineteenth century, from Catherine Beecher on, who demanded 'comfort not only in domestic leisure, but also in domestic work' and for whom the house was more living organism than machine. ${ }^{2 \mathrm{I}}$

Perhaps another reason for the centrality of the coffee table in the home and by implication of the living room in the home - was that although it was

I8 Allen Curnow, Whim Wham's New Zealand: The Best of Whim Wham, 1937-1988 (Auckland: Vintage, 2005), 103. I9 Rybczynski, Home, 202; Los Angeles County Museum of Art, California Design, 1930-1965: Living in a Modern Way (Los Angeles: Los Angeles County Museum of Art, 20II). Californian modern was also premised on an outdoor domestic lifestyle - in this respect see also Andre Taber's dating of the appearance of the barbecue in New Zealand to US-sourced recipes in a 1958 New Zealand Woman's Weekly: Aristologist I (20II). 20 Eugenia Sheppard, 'California Modern: A New, Not-Too-Expensive Decorating Trend', Everywoman's Magazine, September 1947, quoted in Los Angeles County Museum of Art, California Design, 1930-1965, I61.

2I Rybczynski, Home, 158. 
Mattel, Barbie's Dream House, c 1962, with coffee table placed between seating and television. The first Barbie was sold in the US in 1959. When it reached New Zealand is less clear. California Design, 311.

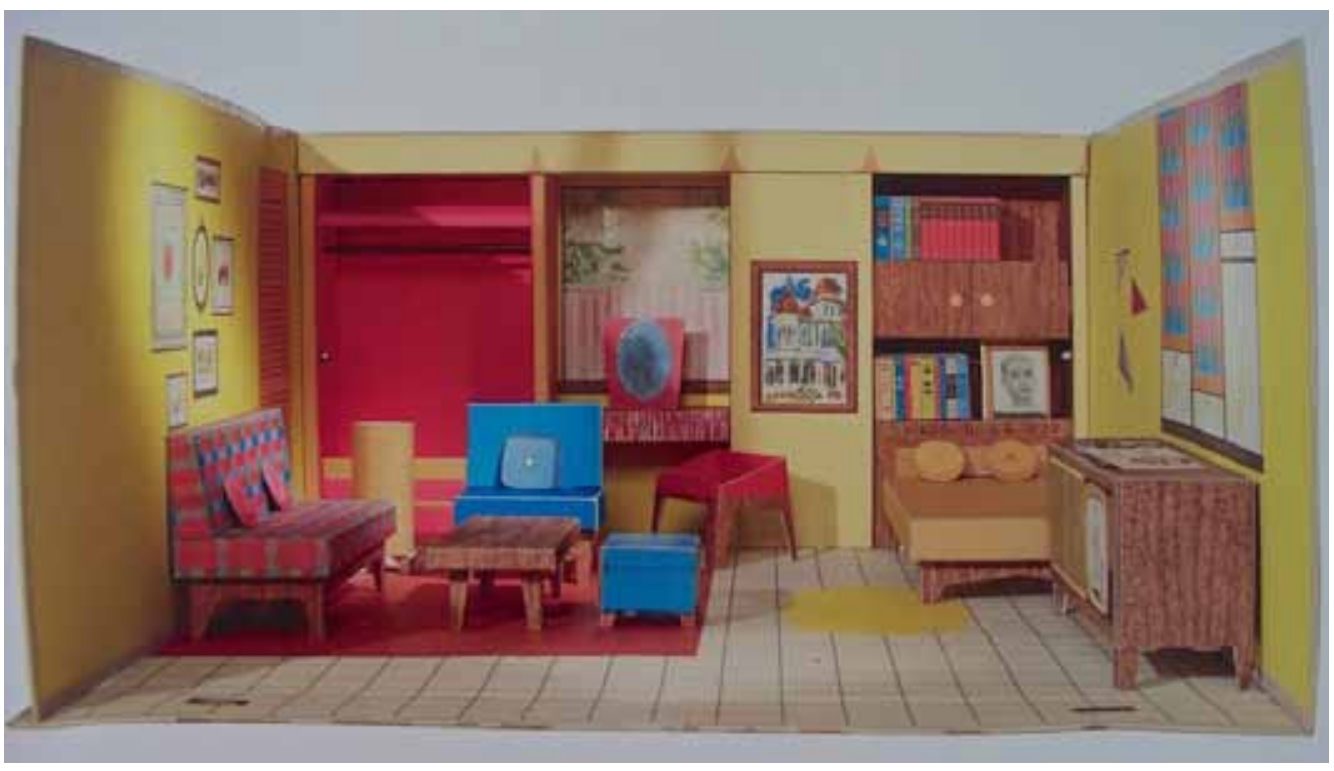

unarguably domestic it was not exclusively feminine and could therefore serve (along with the family car) as a means of integrating the working man into the nuclear family. ${ }^{22}$ And although opening up the living room to the family seems to have transcended a modernist aesthetic, the shift in function from a room reserved for 'best' to one that embraced everyday life and more informal socialising has been widely noted. ${ }^{23}$ Ben Schrader writes that in the first state houses (which deliberately adopted an English Arts and Crafts style rather than the California bungalow model) 'the living room replaced the kitchen as the social hub of family life' and he suggests this was a consequence of the 'conviction that the nuclear family was the foundation of the nation,' a belief that was 'largely unchallenged until the I970s'. Schrader also claims that state house tenants were not so different, in the main, from other New Zealand families, apart from being poorer. ${ }^{24}$ This last observation is lent support by the description of a domestic interior made by Holcroft in his New Zealand essay, which imagined the fictional but supposedly archetypal 'John Matthews', who takes the train home to his wife and three children in the suburbs after work, arriving at 'a wooden house with an iron roof, perhaps not more than ten years old'. It is about 1500 square feet in extent, with 'three bedrooms, a living room, dining room, kitchen, bathroom-lavatory, a sun-porch, and a wash-house'. 'The houses on both sides, and others down the length of the street, are rather similar, and all on identical sections'. 'The dining room is the largest room in the

22 'The man ... held the primary position in the living room': Ben Schrader, 'Planning Happy Families: A History of the Naenae Idea' (MA thesis, Victoria University of Wellington, 1993), 72. Extolling her husband's family values, Michelle Obama told the 2012 Democratic Convention that when she first met him, Obama was 'the guy whose proudest possession was a coffee table he'd found in a Dumpster': 'Transcript: Michelle Obama’s Convention Speech', NPR, www.npr. org/2012/09/04/160578836/transcript-michelle-obamas-convention-speech, 4 September 2012. 23 Louise Shaw, 'A Woman's Place?' in Barbara Brookes, ed, At Home in New Zealand: Houses, History, People (Wellington: Bridget Williams Books, 2000), I76-I77. 24 Ben Schrader, We Call It Home: A History of State Housing in New Zealand (Auckland: Reed, 2005), I42-I47; Schrader, 'Planning Happy Families', 67. 
house, I 8 by I 6 feet, while the kitchen's small size is exacerbated by the presence of refrigerator, dishwasher, electric range and stainless steel bench and sink. ${ }^{25}$ In I957, half of New Zealand homes had a refrigerator or washing machine, but not necessarily both; by 196I, 8I per cent of New Zealand's households had a refrigerator while 78 per cent boasted a washing machine. ${ }^{26}$ It was editor Ray Richards's suggestion that many such homes would have a dishwasher and clothes dryer, but he added, 'mine hasn't'. ${ }^{27}$ Their mention suggests not so much the aspiration of social mobility as, in a book designed to showcase New Zealand to the world, the aspiration to global participation and equivalence. After dinner, Mr Matthews 'retires to the living room, a comfortable place with wall-to-wall carpet and an open hearth'. Beside the 'solid and rather standardised' furniture is a small bookcase with 'perhaps not more than two hundred books', 'most of them school prizes and presents'. Once the children are in bed, the Matthews share tea and fruit cake and discuss 'the prohibitive cost of the family holiday they are planning for the long break at Christmas, and the possibility of buying or renting a television set'. ${ }^{28}$

The possibility of television reflects Holcroft's attentiveness to the moment at which he was writing. In 1963, when New Zealand was published, 8I,839 television licences had been issued. By 1966, the year Don Sinclair avoided descending to the coffee table and just six years after the first public broadcast in Auckland, there were 434,877 licences and two-thirds of homes had a television. ${ }^{29}$ There was no mention of a coffee table in the Matthews' living room, but other writers have suggested that their popularity soared along with television, as they did not obscure the view. While the Matthews drank tea, not coffee, the Woman's Weekly's coverage of coffee emphasised its sociability. Both television and coffee belonged to the many-tributaried river bringing a more globallyinflected modernity into the New Zealand home. Reeds made New Zealand to take its place among these new things.
Unidentified woman demonstrating a dishwasher machine at the Wellington Industries Fair, 1959. Evening Post. EP/1959/1617-F. ATL. http://natlib.govt.nz/ records/23502694.

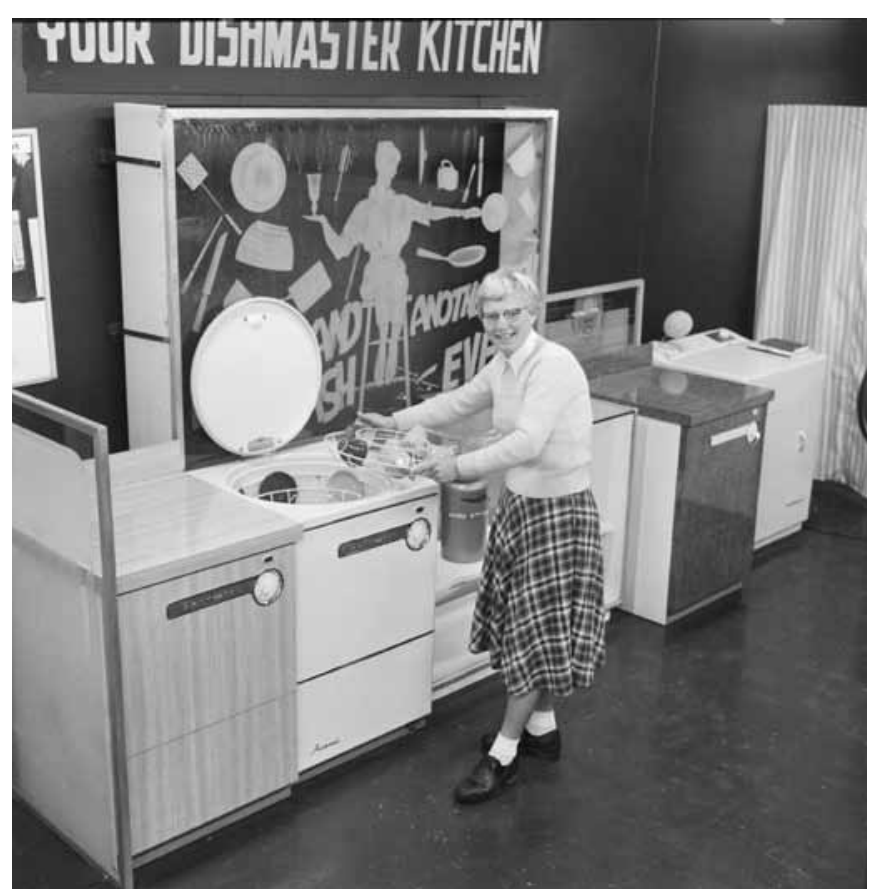

25 Monte Holcroft and Kenneth Bigwood, New Zealand (Wellington: A H \& A W Reed, I963), 20. 26 Shaw, 'A Woman's Place,' At Home in New Zealand, I78; Brian Easton, cited in Ian Brailsford, 'Enlightened Buying', NZJH 4r:2 (2007), I39.

27 Ray Richards to Monte Holcroft, 28 March 1963, A H \& A W Reed records, 79-153-2I/27, ATL. Richards also wondered: 'Is there a pending change in our attitude to Britain?'

28 Holcroft and Bigwood, New Zealand, 20.

29 Comparable figures for other countries were United States, 93 per cent; Canada, 92 per cent; Britain, 83 per cent; Australia, 64 per cent: Department of Statistics, New Zealand Official Year-book 1966, www3.stats.govt.nz/New_Zealand_Official_Yearbooks/1966/NZOYB_I966.html. 


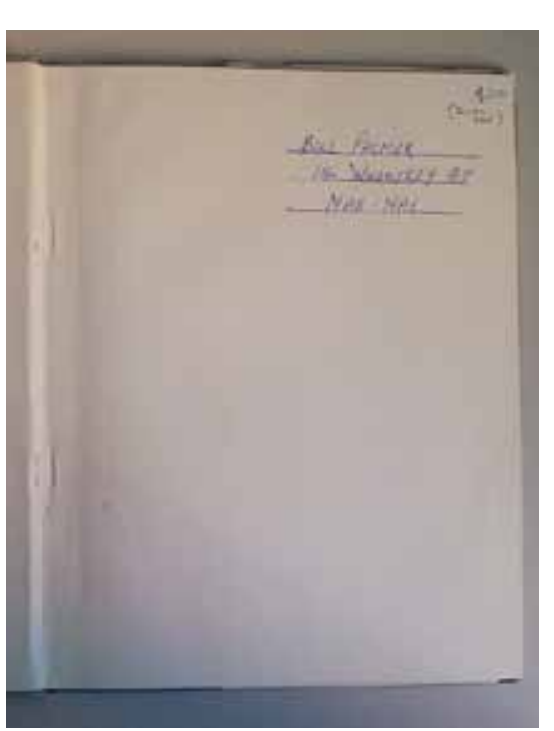

New Zealand in Colour, inside front endpaper.

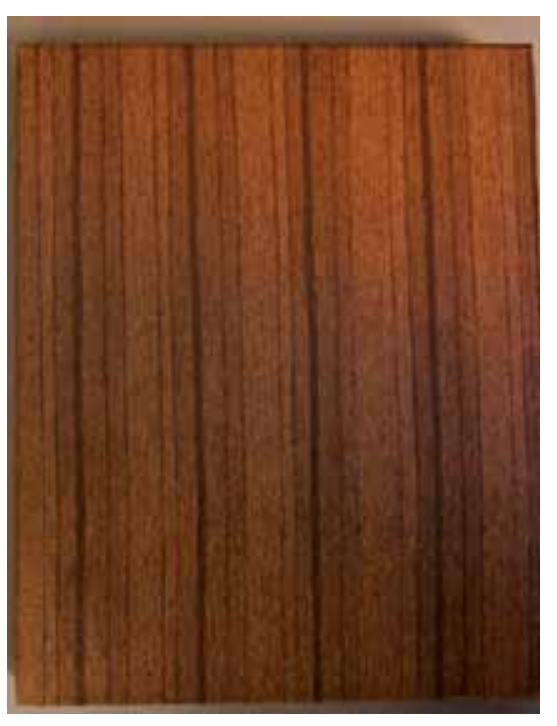

'Gift case of simulated wood veneer' for New Zealand in Colour two-volume presentation set.

\section{Gifts}

Inside the cover, on the endpaper of my second-hand copy of New Zealand in Colour, Bill Palmer wrote his name and address in blue biro. The inscription is neatly underlined: the rules drawn first, you suspect, so that his letters could not wander on the page. I think one can be pretty certain he was the original owner. Who writes their name in a secondhand copy? The books sits snugly with its companion second volume inside a faux wood-veneer card slipcase. In volume two, Bill Palmer of Wheatley St, Nae-Nae became simply W Palmer, Nae Nae. The packaging, and its longevity, suggests a greater sense of the importance of the project for the publisher, and also for this owner. These particular books were a tenth reprinting of volume one in 1972 and a third revised edition in 1973. The Bodoni typeface used on the dust jacket titlings was replaced by 1963, on the first volume, by a typeface reminiscent of Albertus, most readily recognisable on book covers published by Faber $\&$ Faber. The chiselled monumentalism and seriousness of intellectual intent may now seem excessive in a book of images of New Zealand. Perhaps this choice meant to put some distance between it and, say, the Government Printer's 1966 Wonderland of the South Pacific. The contrasting strokes and unbracketed serifs of Bodoni remain redolent of the New Zealand State at its most Fraserian. ${ }^{30}$

The suburb of Naenae in Wellington's Hutt Valley was planned and built by the Department of Housing Construction after the Second World War, primarily to house workers in nearby industrial areas and their families. By the late I950s there was an average of about two children per household and most adults were young recently-married couples, of whom about half the men were returned servicemen. ${ }^{3 \mathrm{I}}$ While the Bigwoods' Wellington image in New Zealand in Colour showed the central city framed by hebes, Baxter thought Wellington was 'becoming increasingly a city of suburbs' and he quoted Louis Johnson's faintly claustrophobic 'Song in the Hutt Valley' to show what lay beyond the picture, 'to the left':

Houses still grow, the children

Like cabbages are seen;

Grandfather's thoughts are hidden

Upon the bowling green .... ${ }^{32}$

\footnotetext{
30 Albertus was cut by Berthold Wolpe in the I930s to resemble letters carved into bronze, with encouragement from Stanley Morison of Times New Roman fame. A German national, Wolpe spent time in an internment camp in Australia during the Second World War. See also Joseph Connolly, Faber and Faber: Eighty Years of Book Cover Design (London: Faber, 2009). 3I It was government policy that half the state houses be available for returned servicemen. This and figures from Schrader, 'Planning Happy Families', I23-I24.

32 Kenneth Bigwood and James K Baxter, New Zealand in Colour (Wellington: A H \& A W Reed, I96I), pl 25.
} 


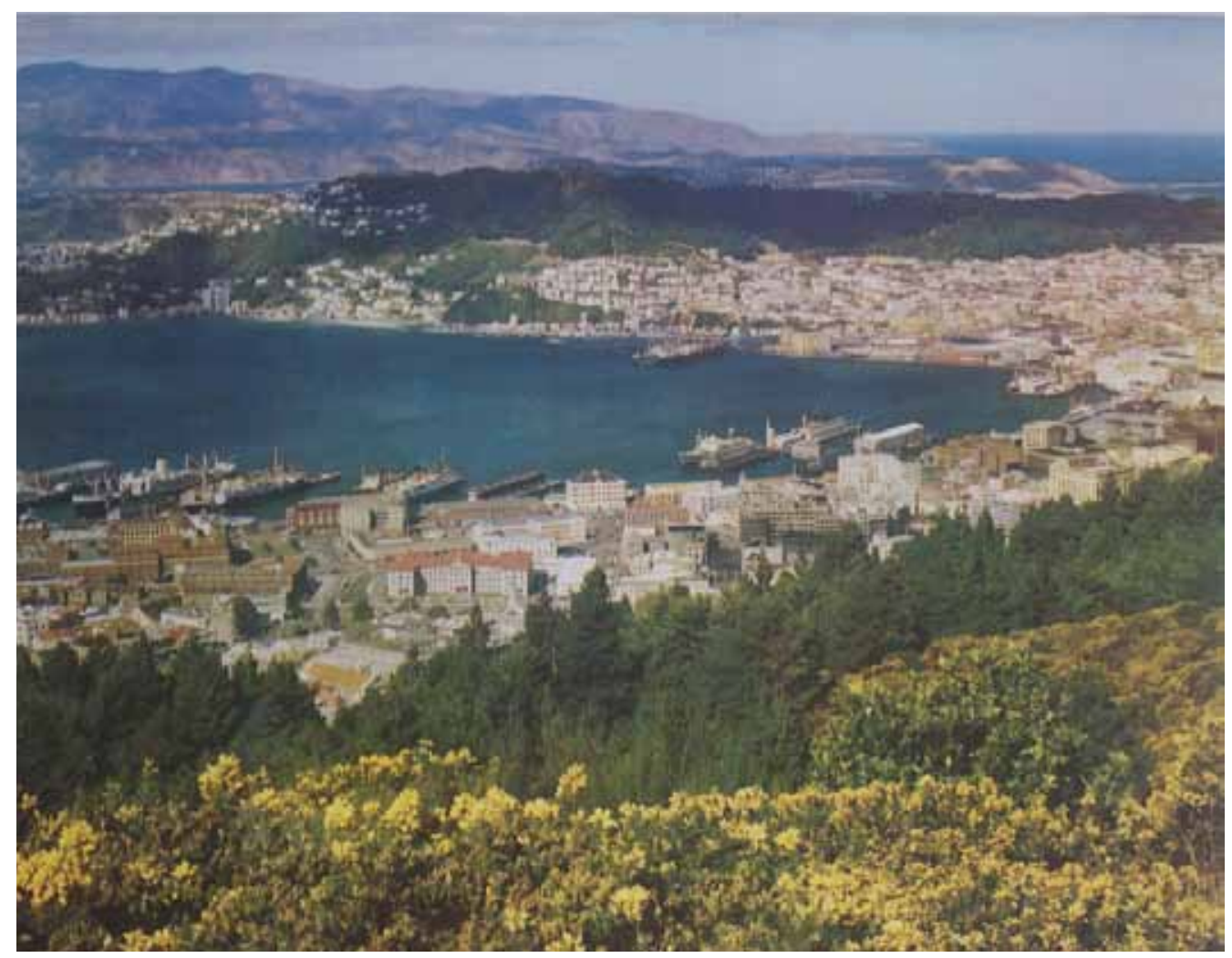

In my own memory, New Zealand in Colour sits on a built-in shelf next to the liquor cabinet, below the west-facing window in my grandparents' Khandallah living room. It shared the space with large-format classics of postwar universalist humanism such Kenneth Clark's Civilisation (1969) and Jacob Bronowski's The Ascent of Man (1973) - each, incidentally, based on a television documentary series. The degrees of separation from Naenae become more acute in a characteristically New Zealand manner: my grandmother Sylvia's knowledge of German (bequeathed by her Swiss mother) helped her befriend immigrants who arrived in Wellington during the I930s from national socialist Germany. Among them were Joachim and Gertrud Kahn: Gertrud's father Robert Larkindale (Lerchenthal) owned Ados Chemical Company, with a factory in Naenae, and the modernist ideas of Ernst Plischke, who designed the Kahn's home, contributed to the blueprint for Naenae's construction. ${ }^{33}$ An apt example, perhaps, of how the global currents of cultural history entered the New Zealand village, but also an indication of the social breadth of the pictorial books' appeal.

How did Bill Palmer come by these books? His inscriptions suggest no answer and, more generally, data that could reveal the reasons why pictorial books were bought is scarce. But what evidence there is points in a consistent direction. Unlike books that were bought to be read, said Reeds' publisher Ray Richards, "'coffee
'Wellington City and Harbour from Tinakori Hill,' plate 25, New Zealand in Colour.

33 Claude Kahn, personal recollection, conversation with author, 2013; Ernst A Plischke, Design and Living, New Zealand and the Future (Wellington: Department of Internal Affairs, 1947), 68-7I. 
Wheatley Street, Naenae, seen by Google Streetview in 2012.

Irene Koppel, 'Kahn House, Ngaio, Wellington', 1941, PAColl-6497, ATL
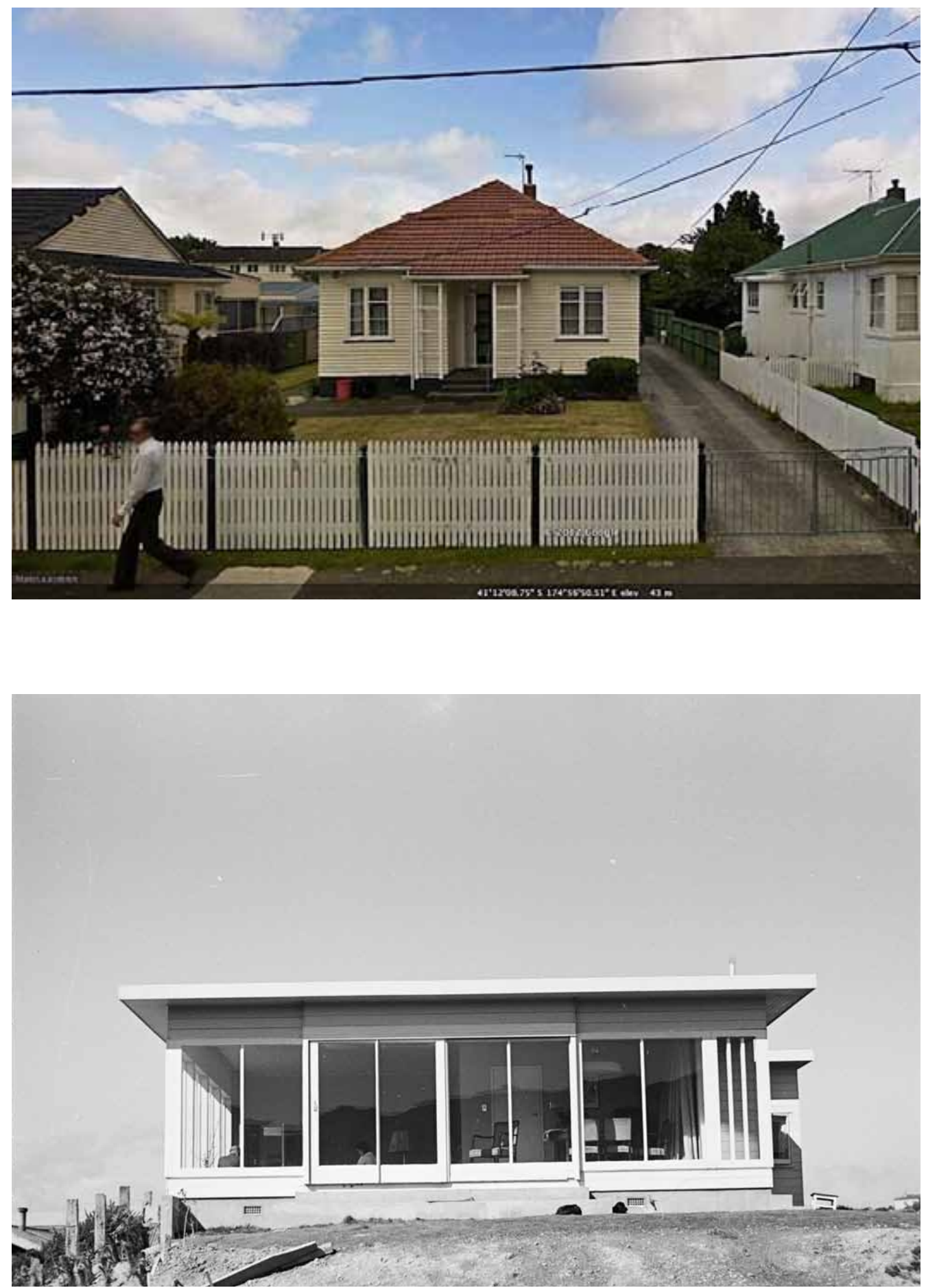

table books" were bought to be given.' 34 The slipcase holding Palmer's books was advertised by the publisher as a 'gift case'. The gift might be in the form of a reward for long service or achievement. A school principal was presented with a pictorial book on his retirement, with the names of all his staff inscribed at the front. ${ }^{35} \mathrm{~A}$

34 Ray Richards, email to author, 5 November 2012.

35 Kerry Popplewell, personal recollection, conversation with author, 2012. 
school pupil chose one as his school prize. ${ }^{36}$ Another was instructed by his parents to use a book voucher won as a school prize to purchase New Zealand in Colour because it was a useful book that could be read - and re-read, more than once. ${ }^{37}$ Presented to foreigners, the gift was part signal of friendship beyond borders and part gentle invocation of national pride. Students were each given a copy of Gift of the Sea to take with them on American Field Scholar exchanges, with the expectation that they would present the book to their host family. ${ }^{38}$ Mrs Weber of Christchurch told Reeds that the colour books made ideal gifts for overseas pen friends. ${ }^{39}$ International gift-giving could take on grander dimensions. Perhaps channeling Andrew Carnegie, Clif Reed claimed that the general manager of New Zealand's Tourist Department flew to Honolulu to present executives of a large American hotel chain with copies of Holcroft and the Bigwoods' big New Zealand book, thus successfully persuading them to visit New Zealand. ${ }^{40}$ It is true that 1963 marked the introduction of the government's Tourist Accommodation Development Scheme, under which Pan American's Intercontinental chain opened a hotel in Auckland in I968.4I Prime Minister Keith Holyoake presented copies of Reeds' colour pictorials to President Suharto when he visited Indonesia in $1964 .{ }^{42}$ Clif Reed's company history included photographs of the Japanese prime minister's wife having her attention drawn to a detail in the Big Book, and Miss New Zealand presenting Melbourne's Lord Mayor with a copy of Peter McIntyre's New Zealand. ${ }^{43}$ These examples were all recorded by Clif Reed himself, and if this is suggestive of his own need for recognition, that might be understandable as an echo of the reciprocity at work in the original transaction. With no reading required, the pictorial book was a suitably neutral offering; it combined a populist aesthetic, advanced technology, and the proposition that the country was a nice place to visit and to look at. To accept such a gift was to endorse a claim that New Zealand was able to seamlessly take its place in the modern world. Noticeably, Reed had no stories of his pictorials being given to British recipients.

The most significant form of the gift was the Christmas present. John Pascoe made full use of the complimentary copies he received for his work on the second volume of New Zealand in Colour, sending I8 copies to family and friends

36 Malcolm McKinnon, personal recollection, conversation with author, 2013.

37 Suzanne Manning, personal recollection, conversation with author, 2013.

38 Jocelyn Chalmers, personal recollection, conversation with author, 2012.

39 Mrs Weber to A W Reed, 30 November 1976, A H \& A W Reed: Author files and book proofs, 89-IIO-O2, ATL.

40 A W Reed, Books Are My Business: The Life of a Publisher (Reading: Educational Explorers, 1966), 88.

4I Margaret McClure, The Wonder Country: Making New Zealand Tourism (Auckland: Auckland University Press, 2004), 212-213.

42 Clif Reed to AH Reed, 8 April 1964, cited in Edmund Bohan, The House of Reed 1907-1983: Great Days in New Zealand Publishing (Christchurch: Canterbury University Press, 2005), I35.

43 A W Reed, The House of Reed, 1957-1967 (Wellington: A \& \& A W Reed, I968), between 46-47. 


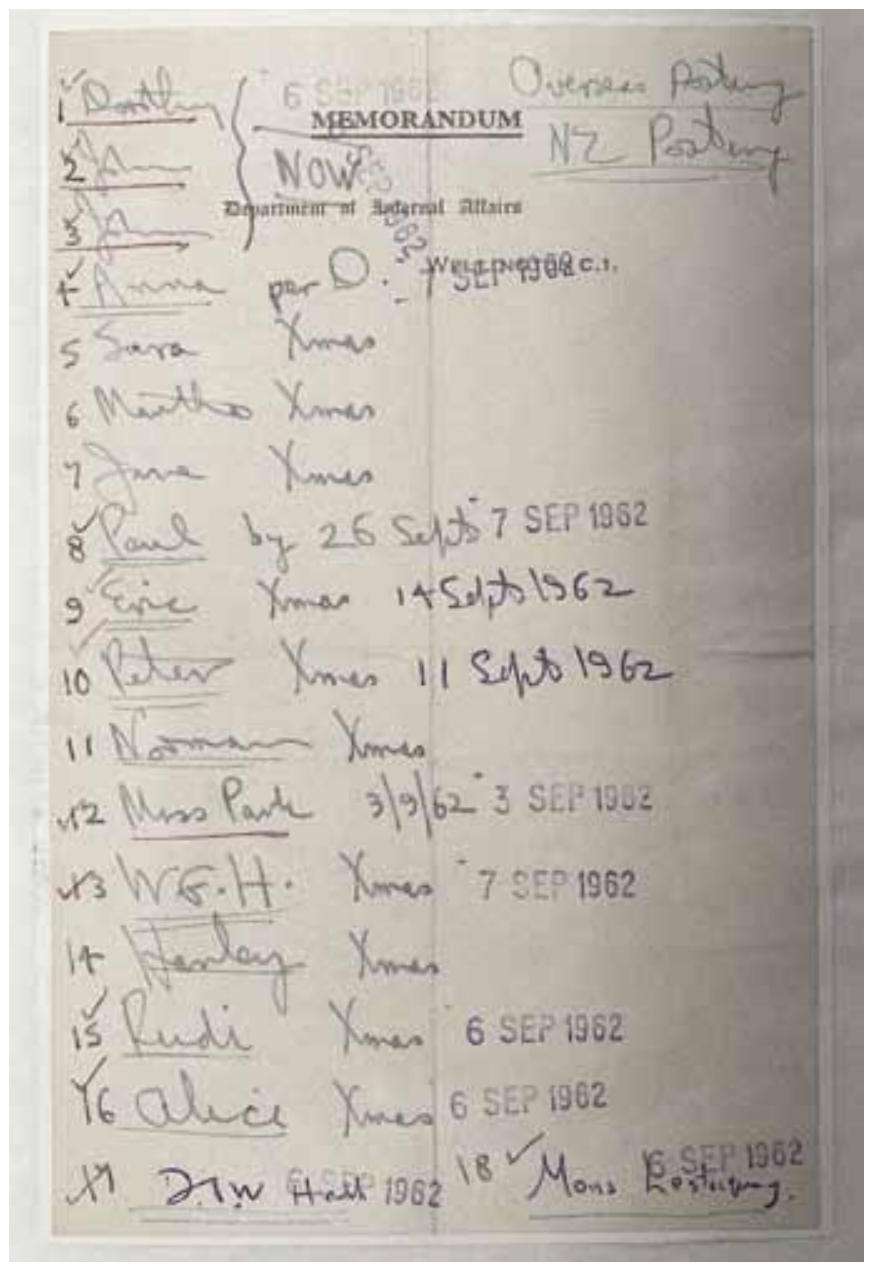

John Pascoe's posting list for Christmas 1962. Everyone received a copy of New Zealand in Colour, Volume Two. as Christmas gifts, plus another to his brother Paul as a birthday present. ${ }^{44}$ Baxter wrote to his mother in October 1961:

I intend to present you with REEDS' new book of photographs of New Zealand (coloured) for which I did the 8,000 word script; and Daddy with my new book of verse from Oxford University Press, which should be out in the shops by the beginning of November. These will be your Christmas presents from me: so don't buy them yourselves. ${ }^{45}$

Christmas was the acknowledged high point of the publisher's and bookseller's year, although along with the jump in income from November through to January came the stress of a massively uneven cashflow. Similarly large costs had already been incurred, either to produce or to purchase books. Bennetts book shop in Palmerston North sold 1905 paperbacks in December 1963, against an average of 1085 per month for the rest of the year. ${ }^{46}$ Among Reeds' books, pictorials made up a substantial proportion both in absolute income and quantity of Bennetts' sales. During November and December 1962, Bennetts sold 23 Reed titles, a total of 1406 books and $£$ I450.2.4 income. Three Reed pictorials, New Zealand in Colour volumes one and two, and Peter McIntyre's Painted Years, brought in over one third of that amount, £572.II.6. They were also the most expensive: the two colour books cost 25/- each and the McIntyre 36/-. These were sizeable sums although, for comparison, an annual television license cost $£^{6 / \text { Io }}$ in 1961. ${ }^{47}$ New Zealand in Colour Volume Two was also the top seller, with 236 copies sold for a total $£ 295$. Its closest competition came from Barry Crump’s One Of Us which sold 168 copies and brought in $£$ I34.2.4. ${ }^{48}$

44 List of people to send Christmas presents, John Pascoe papers, 'File relating to New Zealand in Colour (v2)', MS-papers-8I79-30, A TL.

45 James K Baxter to Millicent Baxter, I8 October 196I, James K Baxter literary papers, Letters from Baxter to his parents, I953-1972, MS-II36/ 026, Hocken Library. Millicent took a greater interest in photography, which may explain the allocation.

46 Bennett's Bookshop, sales list, I963, Whitcoulls archive no 2, Box J, Bennetts, 20II/25 JI7, AWMML. In a second undated list spanning July to December the difference is greater: 2077 books in December; 848 per month otherwise.

47 Department of Statistics, New Zealand Official Year-book 1962, sec I2B, www3.stats.govt.nz/ New_Zealand_Official_Yearbooks/1962/NZOYB_1962.html.

48 Bennett's Bookshop, sales list of Reed books, 1963, Whitcoulls archive no 2, Box J, Bennetts, $20 I I / 25$ JI7, AWMML. 

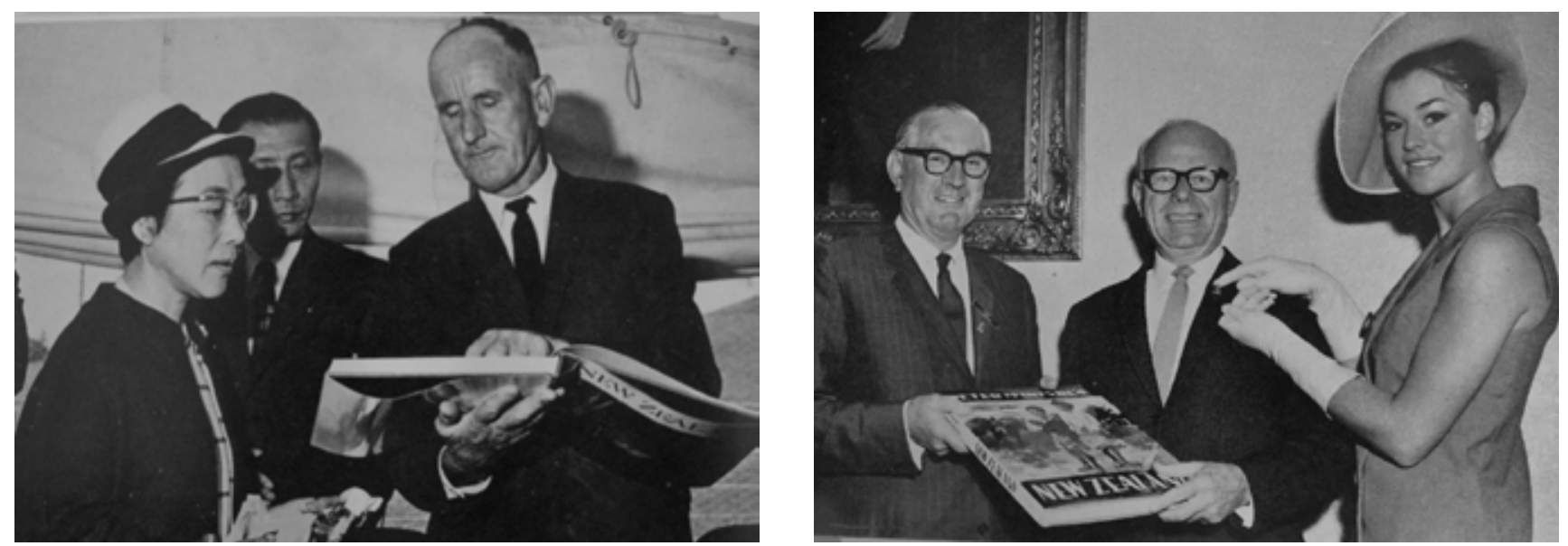

Presentation volumes: left, CF Jones of the Meat Producers' Board points out a detail in New Zealand to the wife of the Japanese Prime Minister; right, Miss New Zealand presents Peter Mclntyre's New Zealand to Melbourne's Lord Mayor. Both images from The House of Reed, 1957-1967.

Popular book publishing and selling has depended on Christmas since that ritual assumed its modern form in the early years of the nineteenth century - although it might be more accurate to say anti-modern form. The tension between commercialism and authenticity was embedded from the start, as Stephen Nissenbaum noticed when tracing the early history of Christmas presents, wryly noting Harriet Beecher Stowe's plea for a more authentic and less commercial Christmas in I850, while rushing to buy presents 'for people who have more than they know what to do with now'. When she was a child, 'the very idea of a present was so new' while now, 'There are worlds of money wasted, at this time of year, in getting things that nobody wants, and nobody cares for after they are got.' Nissenbaum notes the perennial nature of the lament, but points out that in her case it was 'substantially correct' ${ }^{49}$ In chapter I I noted the advent of the gift book, its link with Christmas, and the particular, British-influenced forms it took in New Zealand. Looking for antecedents of the colour pictorials among New Zealand gifts, books, nature and images are all identifiable among the nineteenth-century New Zealand Christmas presents recorded by Alison Clarke. In I858, Eliza Jones received a 'handsomely bound book of ferns' from her brother in Britain. The Dunedin bootmaker Jack Fowler sent back photographic Christmas cards from the I890 New Zealand and South Seas Exhibition, a piece of pounamu he had found, ferns, and a 'book of views'. There was 'always a book' in Ellen Windsor's Christmas stocking in the I890s. ${ }^{50}$ Gifts might comprise not only books about nature (views), but natural items bound (books of ferns) and unbound (ferns, pounamu).

49 Stephen Nissenbaum, The Battle for Christmas (New York: Vintage Books, 1997), I34; Harriet Beecher Stowe, 'Christmas', in National Era, 26 December 1850, www.readbookonline.net/ readOnLine/42658/.

50 Alison Clarke, Holiday Seasons: Christmas, New Year and Easter in Nineteenth-century New Zealand, (Auckland: Auckland University Press, 2007), 64-67. 


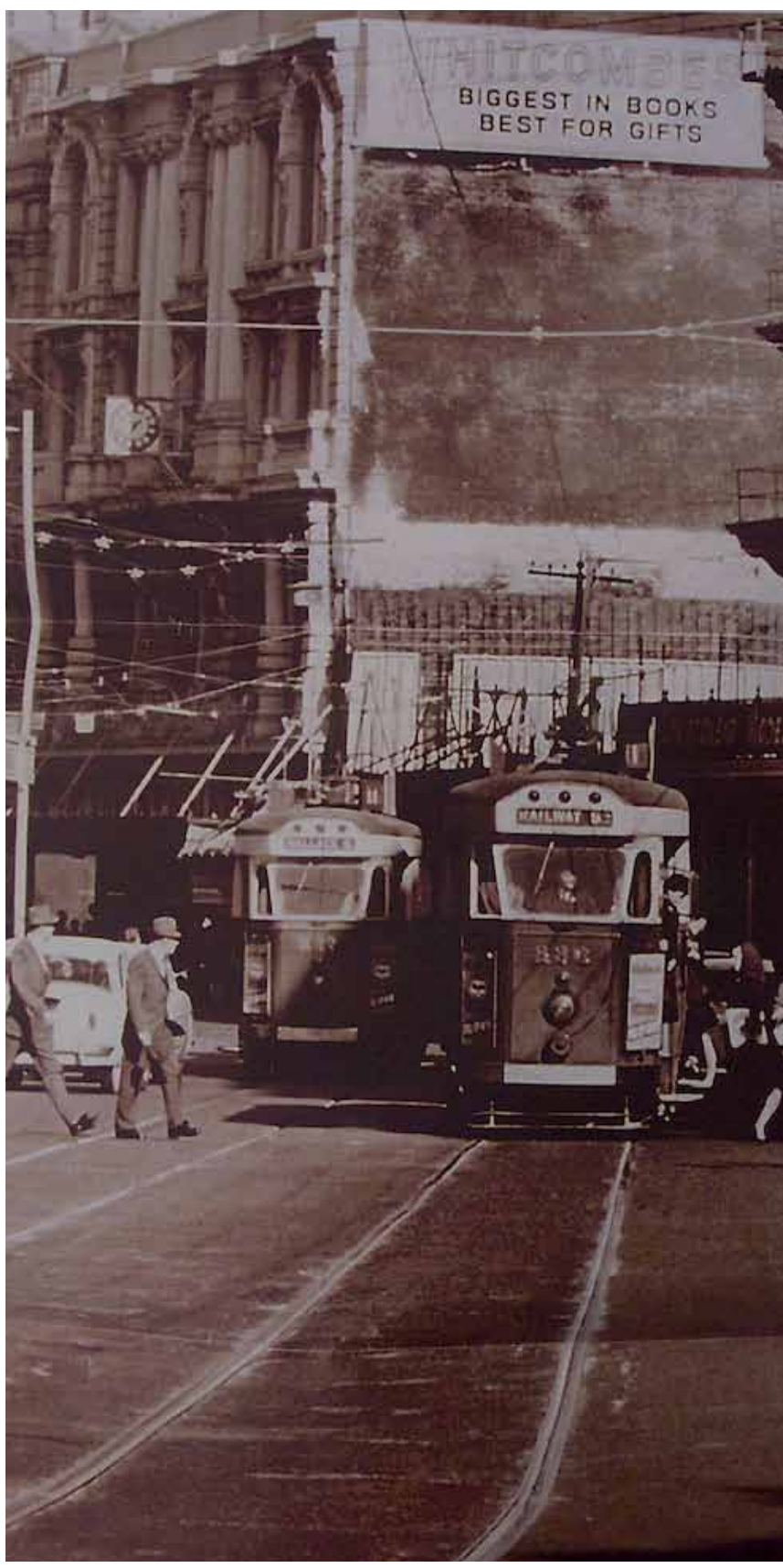

'Whitcombes', Biggest in Books, Best for Gifts': sign on Whitcombe \& Tombs' Lambton Quay shop, Wellington, undated. Whitcoulls archive no 2, MS 2011/25 G9 Sundry, AWMML. of this observation.
Historians of Christmas agree that the essential characteristics of the modern ritual were in place by the early twentieth century. Later changes worked simply to increase their scale and intensity. ${ }^{5 \mathrm{I}}$ In New Zealand, as in the northern hemisphere, the ancient traditions of wassailing, mischief, and drunkenness were steadily sidelined by more acceptable bourgeois practices of carol singing, gift-giving and amused tolerance of childish pranks.

Nissenbaum argues that Christmas played a crucial role in the widespread acceptance of consumerism: 'For this was one time of the year when the lingering reluctance of middle class Americans to purchase frivolous gifts for their children was overwhelmed by their equally lingering predisposition to abandon ordinary behavioural constraints. '52 The colour pictorials were not, one suspects, primarily given to children, but much of Nissenbaum's analysis of the gift book seems nevertheless applicable. They were manufactured to be given away by the purchaser, and they were among the most expensive books their purchasers ever bought. Their origin as a mass-produced commodity was disguised by their subject matter, which embodied the anti-modern escape from the city into nature. ${ }^{53}$ Further, socially appropriate gift-giving was fraught with difficulty. Horace Greeley wrote in the New York Tribune in 1846: A present given to create a sense of obligation, even to a dependent or child, becomes at the best a Charity, humiliating rather than inspiring the receiver. 54 Thus, to express sentiment rather than fulfil a need, the appropriate gift was a luxury item. The long-standing joke about giving father a gift of socks, cigarettes, or shaving stick reflects the truth

5I See for example Nissenbaum, The Battle for Christmas; Clarke, Holiday Seasons; John Alfred Ralph Pimlott, The Englishman's Christmas: A Social History (Hassocks: Harvester Press, 1978); William Burnell Waits, The Modern Christmas in America: A Cultural History of Gift Giving (New York: New York University Press, I993), http:/ / muse.jhu.edu/books / 9780814794869.

52 Nissenbaum, The Battle for Christmas, I39.

53 Ibid, I43-I48.

54 Horace Greeley, New York Tribune, I846, quoted in ibid, I47. 


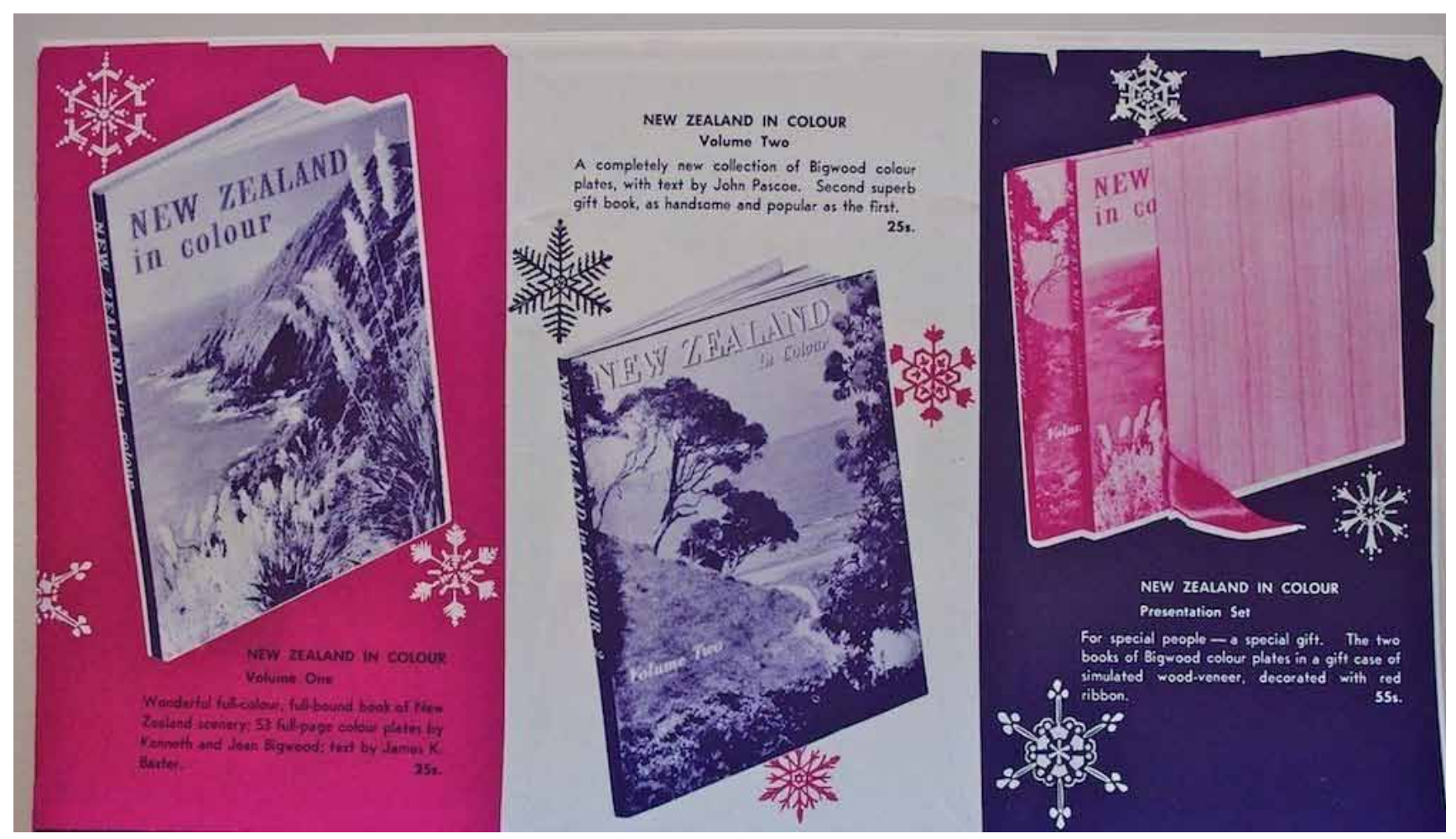

Detail from Reeds' Christmas books

Reeds' 1962 sales brochure suggested that the pictorials would make special brochure, 1962. gifts for special people - particularly when, for an extra five shillings outlay, two books might be given in a 'gift case of simulated wood-veneer, decorated with red ribbon'.

Part of the success of the pictorial book, in fact, lay in its ability to transcend gendered assumptions about gifts. It encompassed the aestheticised sentiment, middle class values, and links with the natural world that were regarded as suitable qualities in gifts for women and children. In the formal listing and structuring of information - the map as a key to the images, the apparently comprehensive geographic coverage, and (particularly in Pascoe's captions) the summaries of key facts - the desire to encourage self-improvement was mixed with the indulgence of the colour image. To the extent that these characteristics mimicked the almanac, the encyclopedia and the atlas, this made the books suitable for children but also for grown men. And whether sitting on the coffee table below a brand new television, or among the two-hundred-odd school prizes and presents on the small bookcase, they had found a home, recalling Schrader, in the social hub of the foundation of the nation.

In How to Do Things with Books in Victorian Britain Leah Price writes: 'For the producer to devote his earnest attention to any object, no matter how trivial, implies an ethic of service; aesthetic attention on the part of consumers, however, implies self-indulgence. ${ }^{\prime} 5$ When the book becomes a gift this distinction is successfully subverted. Price's observation offers support for the idea that material things

55 Price, How to Do Things with Books in Victorian Britain, 29-30. 
lack an essential, fixed identity but instead are socially transformed and open to recontextualisation; adding the dimension of the gift introduces a further context, in which the recipient's indulgence of aesthetic attention may be justified..$^{56}$ Desire is transfigured into a more acceptable form: the school prize is offered as a reward for sustained effort; for the Prime Ministerial gift the reward comes from recognition; and much of the value of the Christmas present lies in the fact that responsibility for the indulgence can be shared. All of which suggests that the colour pictorial book succeeded in no small part because of its ability to form connections, via giftgiving, between a surprising variety of people in a wide range of social settings.

\section{Dreams of home}

As objects, the colour pictorials participated in a societal shift to consumerism that focused more attention in the home but simultaneously opened domestic spaces up to the world. Purchasers employed the gifting strategies described earlier to navigate the potential pitfalls of the books' status as a luxury commodity, but also as a means of accomodating this need to look outwards while looking inwards. Such considerations were common to all coffee table books but, in the terms established at the beginning of this chapter, those given the name "New Zealand" form a special case. Specifying the particular rhetorical and social uses to which these colour pictorials were put helps to explain what it meant to be at home with New Zealand in the ro6os.

The drawing opposite was not published until 2012, but it was made in 1944 towards the end of the Second World War by Stag Spooner, a Wairarapa deerstalker who served in North Africa and Italy. Among the beautiful and intricate line drawings he produced there, this one stands out: 'A Kiwis Dream of Home'. ${ }^{7}$ The intensity of the dream is almost disturbing and even hallucinatory. It is a place that has been intently imagined for years, perhaps inside the armoured vehicles of the 2nd New Zealand Division as they traversed the real world of desert, dust and death. When Deborah Montgomerie investigated how men and women negotiated the impact of the war, she pointed to John Mulgan's 'dream of a New Zealand with "more children in the sands and sunshine"” ${ }^{88}$ She noticed, in soldiers' writings, a 'self-consciously dreamlike and wistful quality to many of the depictions of women' - a quality that gains resonance in light of the much-analysed nationalist project of gendering the landscape. ${ }^{59}$ But the contrast between here and there was

56 Thomas, Entangled Objects, 28.

57 Chris Maclean, Stag Spooner Wild Man from the Bush: The Story of a New Zealand Hunter and Artist (Nelson: Craig Potton, 20I2).

58 Deborah Montgomerie, 'Sweethearts, Soldiers, Happy Families: Gender and the Second World War' in Montgomerie and Caroline Daley, eds, The Gendered Kiwi (Auckland: Auckland University Press, 1999), I65.

59 Montgomerie, ibid, I82; See especially 'What sex is the Nationalist's country?' in 'Pastoral and the land as lover', Francis Pound, The Invention of New Zealand: Art \& National Identity, 1930-1970 (Auckland: Auckland University Press, 2009), 206-223. 


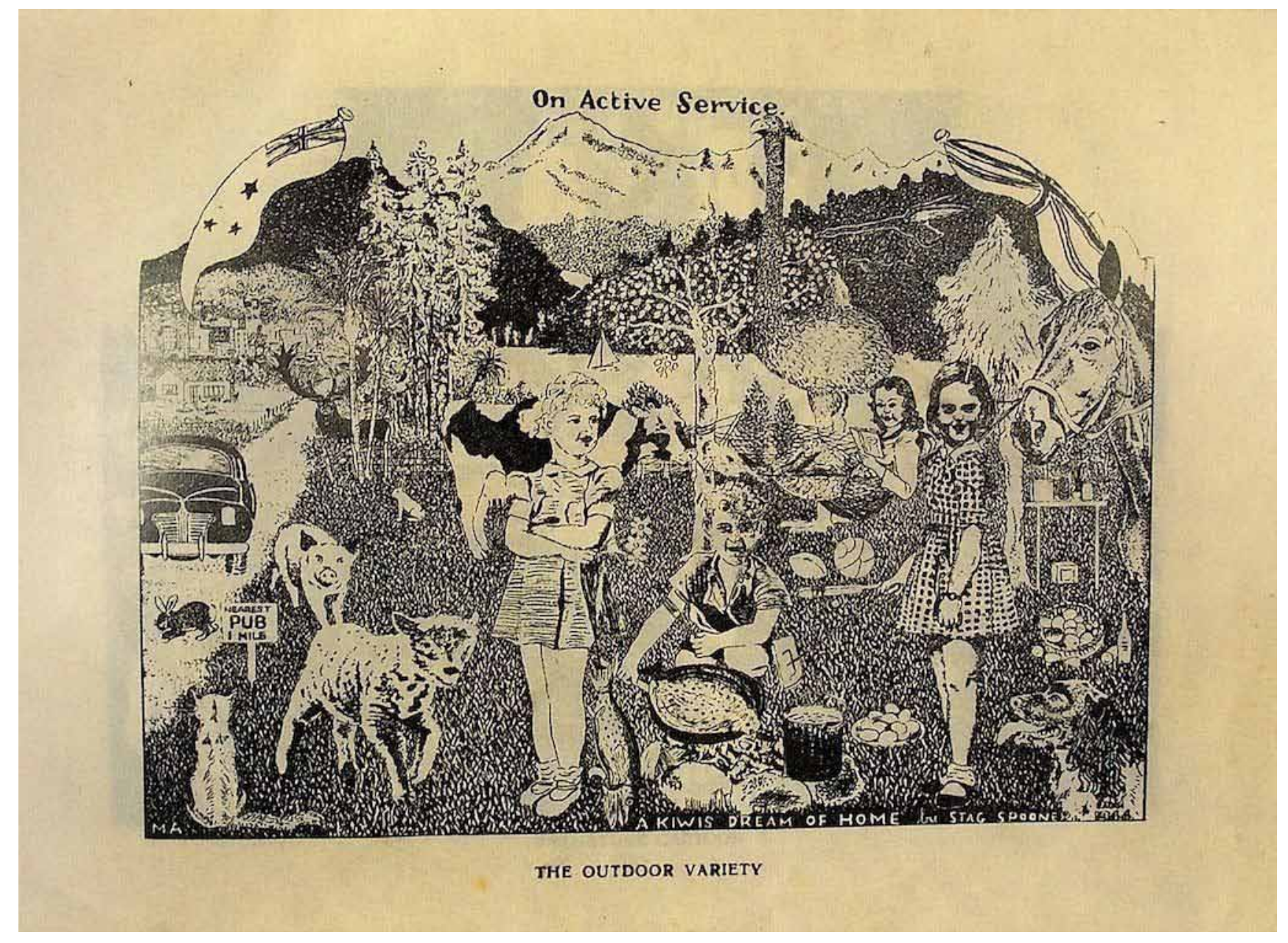

THE OUTDOOR VARIETY

also clear to those still in New Zealand, as these extracts from letters written in New Zealand show:

You've no idea how hard it is to write to you over there in all that hell. . . . It rained last night and that heavenly earthy smell you get after rain is intensified by the still, moist atmosphere. ${ }^{60}$

... when you come back home. I promise to make it seem a paradise. ${ }^{6 \mathrm{I}}$

The narrative of the "scenic paradise" was largely invented for the purpose of impressing non-residents: tourists, prospective migrants, and the British elite on whom cultural validation depended. In Spooner's drawing we can see a striking inversion of this practice, where the New Zealander I2,000 miles distant looked back his way. And if the distinction between the devastation of Europe and the comforting ease of God's Own Country was implicit, the examples in the letters
Stag Spooner, 'A Kiwis Dream of Home,' in Chris Maclean, Stag Spooner Wild Man from the Bush, 189; originally printed in Cairo in 1945 in Spooner's Tatooed Envelopes.

60 June Cummings to Duncan Gray, 3 December 194I, George Duncan Dunbar Gray papers, Ms-papers-2086, flr 3, ATL, quoted in Montgomerie, The Gendered Kiwi, I74.

6I Gay Gray to Duncan Gray, George Duncan Dunbar Gray papers, Ms-papers-2086, flr I, ATL, quoted in Montgomerie, ibid, $\mathbf{1 7 6 .}$ 
quoted above spelled it out. The American novelist James A Michener was in New Zealand during the war and later observed that 'I have never met people more deeply convinced that theirs is the one good land. ${ }^{62}$ Raised on a diet of Better Britain, perhaps New Zealanders' experiences of wartime London heightened a feeling of gratitude for their lot.

Against an argument that the war was a seminal influence on the colour pictorial books, the objection might be raised that none of the authors or photographers were directly involved in the war. Baxter, Maurice Shadbolt and Brian Brake were too young. Holcroft was too old. John Pascoe was rejected as unfit for military service (despite being a compulsively fit runner and mountaineer). ${ }^{63}$ Photographer Kenneth Bigwood was 20 years old when conscription was introduced in July 1940, but seems to have avoided that fate. He married Jean Bigwood in 1944, around the time he began work in Christchurch as a photographer for National Publicity Studios. ${ }^{64}$ Nevertheless, Baxter's biographer Frank McKay claimed that the war and especially its aftermath as the world absorbed the horror of nuclear weapons and genocide - produced a 'deep disillusion'. McKay uses the Thomas Kenneally of Schindler's Ark to make his point, that Baxter, Colin McCahon, Bill Pearson and others suffered 'a derangement in that area of the brain in which stable ideas about humankind are kept'. ${ }^{65}$ And in 1943 , Holcroft had written about 'the nationalist dogmas which have brought ruin and shame to European nations'. ${ }^{66}$

But by the early 196os, thousands of men and women who had served in the war were running homes, businesses, farms and institutions, and their generation began to exert real influence over the social, cultural, and economic life of the country. They had good reasons to be grateful to be New Zealanders: they had been provided with generous subsidies for career training and low-interest loans to purchase houses, farms and businesses. Between 1944 and 1963, £264 million was spent on the rehabilitation of 217,I79 servicemen and women. ${ }^{67}$ Among them were the three men who, after Clif Reed, played the most influential roles at A H \& A W Reed. Tom Kennedy was in charge of sales, Ray Richards ran the editorial department, and Don Sinclair managed production. These were the men who created the colour pictorial books, deciding on the requirements of form and content and then locating and contracting the appropriate people to supply the goods: the writers,

62 Quoted in Desmond Stone, ed, Verdict on New Zealand (Wellington: Reed, 1959), 19.

63 Chris Maclean, John Pascoe (Nelson: Craig Potton Publishing, 2003), I29.

64 Rocky Mountain Online Archive, 'Kenneth and Jean Bigwood: An Inventory of Their

Photographs at the Denver Museum of Nature \& Science', http://rmoa.unm.edu/docviewer. php?docId=codmnhiabi97. $x m l$, accessed 20 August 2013.

65 Thomas Kenneally, Schindler's Ark (1982), I50, quoted in Frank McKay, The Life of James K Baxter (Auckland: Oxford University Press, 1990), II5.

66 Monte Holcroft, The Waiting Hills (Wellington: Progressive Publishing Society, 1943), ch 3, 'The Dream of Happiness'.

67 Mark Derby, 'Veterans' assistance - Economic rehabilitation', Te Ara - the Encyclopedia of New Zealand, updated I3 July 20I2, www.TeAra.govt.nz/en/veterans-assistance/page-2; Melanie Nolan, 'Constantly On the Move, But Going Nowhere?' in The New Oxford History of New Zealand (Melbourne: Oxford University Press, 2009), 382. 
photographers, and printers. Two examples from Reeds' publications suggest the lasting influence of the Second World War.

The first is from Baxter's introduction to New Zealand in Colour. He mentioned the English writer Lawrence Durrell's conception of "islomania", describing it as 'a rare but by no means unknown affliction of the spirit', whose sufferers 'find islands somehow irresistible'. Durrell invented the idea to describe the mental state of English expatriates on Rhodes in Greece after the war. For Baxter, though, 'Any New Zealander ... who cuts the navel-cord that binds him to England or Europe, and lives his life through on the terms that these islands dictate to him, is probably in Durrell's sense an "islomane". '68 A larger argument exists that, as a general tendency, a particular character is bestowed upon islands in western culture. The geographer John Gillis writes that:

The chimerical character of islands is not just a product of physical conditions. It is equally a result of culture - Western mainland culture, to be specific - which has attributed to islands certain wondrous features that it rarely bestows on other landforms. ${ }^{69}$

So, we might ask, what were the wondrous features that New Zealand soldiers, steeped in Western culture, bestowed on their own islands while they suffered through the destruction in Europe?

A striking answer can be found in New Zealand Holiday magazine, established by - no surprise, perhaps - Ray Richards at Reeds, who between 1956 and 1960 produced it quarterly for the New Zealand Travel and Holidays Association. The association aimed to increase the number of overseas visitors to New Zealand, improve tourist and holiday infrastructure and services, highlight the economic value of tourism, and 'foster among New Zealand residents the practice of travel and holiday-making within New Zealand'.$^{70}$ The first article in the first issue was composed by a returned serviceman, John Hardingham. By 1956 he was a journalist for the New Zealand Herald and author of The Queen in New Zealand. This is what he wrote:

When I was away from New Zealand for six years during the war I thought a lot about my country. And I remember the thoughts were less of places than of a vaguer, more general, more indeterminate scene. The eye of memory recaptured a clean, green landscape with misshapen monsters of white cumulus cloud lolling in a clear blue sky. ${ }^{7 \mathrm{~T}}$

68 Bigwood and Baxter, New Zealand in Colour, introduction.

69 John R Gillis, 'Island Sojourns', Geographical Review 97:2 (April 2007), 274-287.

70 JH Richards, New Zealand Holiday Horizons: Selected from New Zealand Holiday (Wellington: A H

\& AW Reed, 1958), inside back dust jacket.

7I John Hardingham, 'New Zealand - Land of Variety', New Zealand Holiday I (1956): 7 

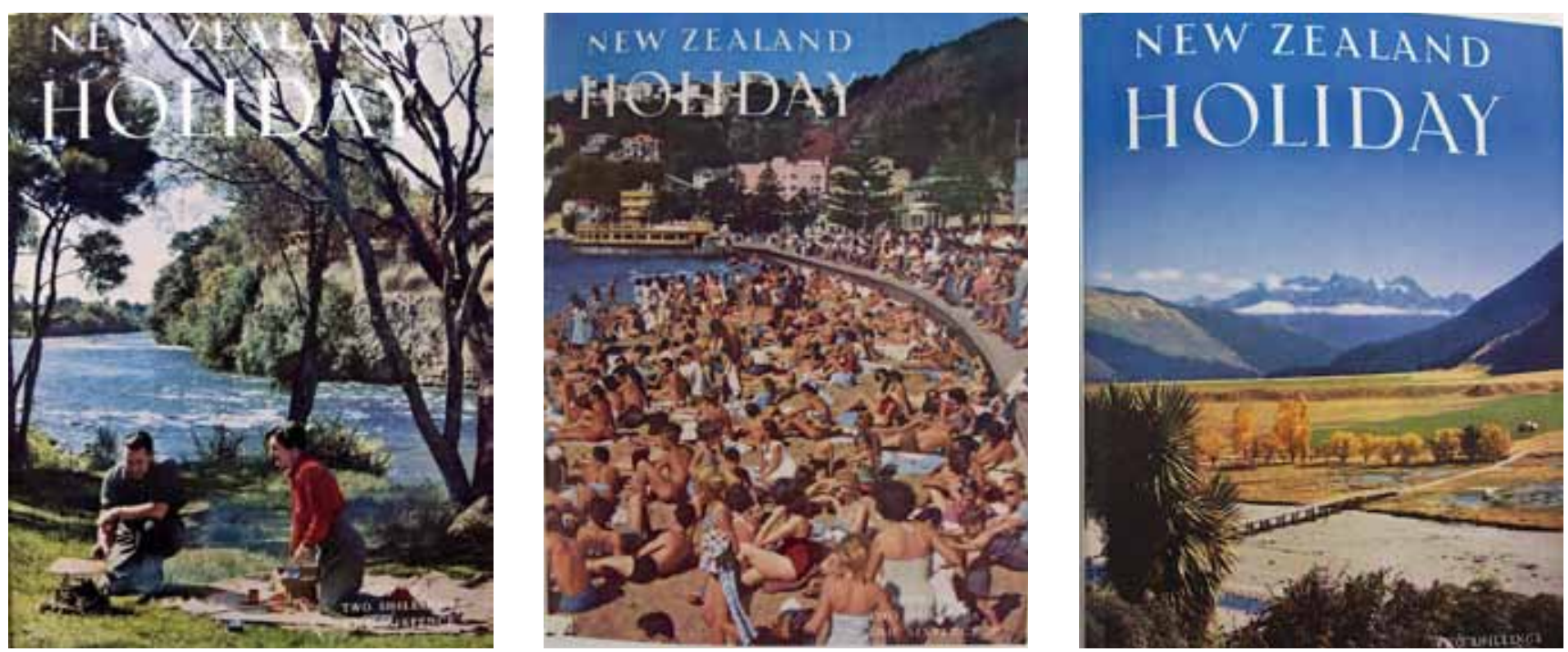

Covers from New Zealand

Holiday magazine.

Clean and green. There is a phrase that has stuck. ${ }^{72}$ Hardingham continued: 'The memories are once again happy realities, and I live them with no sense of disillusionment.'73 If the mainland - or perhaps the homeland - could produce 'deep disillusion', the islands of New Zealand possessed restorative powers.

The sense that New Zealand required an emotional response is present on the dust jackets of the colour pictorials. The blurb in Gift of the Sea called it the work of 'two New Zealanders who love their country'. The 'loved scenes' in the big New Zealand book were 'devotedly produced' to 'view with affection'. Ending his New Zealand in Colour introduction, Pascoe suggested it was challenging to remain calm while writing about 'country that I love with fire and passion'. ${ }^{74} \mathrm{He}$ later told his brother Paul that he had enjoyed working on the book immensely: many of the scenes were close to his heart and his captions had 'plenty of guts as well as imagination' ${ }^{75}$ Later, responding to a letter of thanks from the chairman of the National Parks Authority, Pascoe thought that he might have written about the parks 'subconsciously in a spirit of gratitude that, as a New Zealander, is inherent' ${ }^{76}$ Gratitude, of course, is an appropriate emotional response to a gift.

In their texts, James K Baxter and Maurice Shadbolt make a particular claim for New Zealand-ness. This is Baxter in New Zealand in Colour:

72 The fact that 'image' is, today, so often added without reflection or irony is a strong indication that it continues to express a deeply-rooted truth about how many New Zealanders see their country.

73 Hardingham, New Zealand Holiday I (1956): 7.

74 Kenneth Bigwood and John Pascoe, New Zealand in Colour: Volume Two (Wellington: A H \& A W Reed, 1962), introduction.

75 John Pascoe to Paul Pascoe, 4 March 1962, John Pascoe papers, 'File relating to New Zealand in Colour (v2) (b)', MS-papers-8I79-3I, ATL.

76 John Pascoe to EJ G Price, chairman National Parks Authority, II September 1962, John Pascoe papers, 'File relating to New Zealand in Colour (v2)', MS-papers-8I79-30, ATL. 


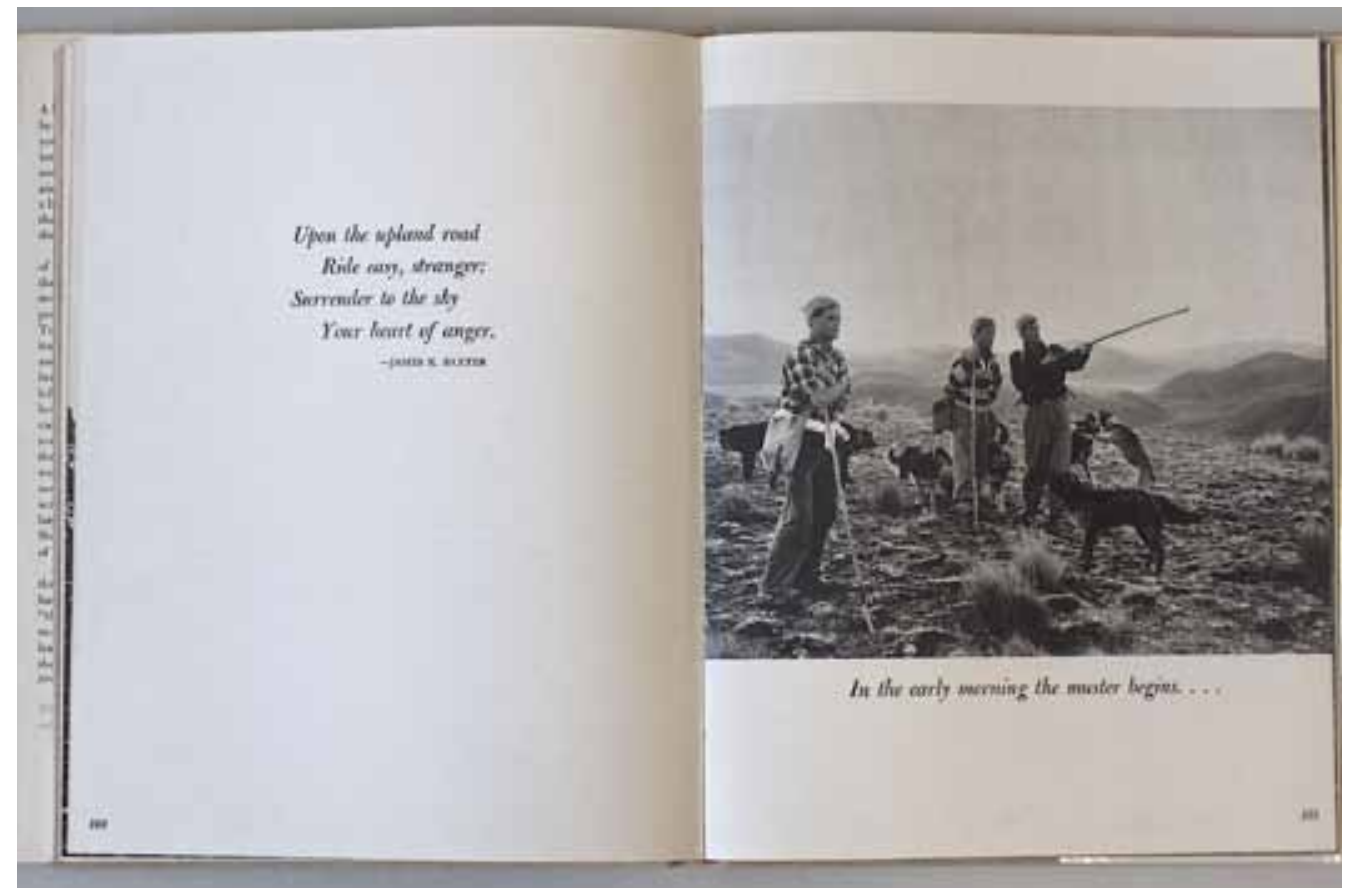

A very few Pakehas also - fishermen, deer-cullers, back-country shepherds, gold prospectors - have established a true relation to the Wilderness and been able to inhabit the country they were born in. To such men this book would seem unnecessary; for they already know all it could show them. ${ }^{77}$

And this is Shadbolt in Gift of the Sea:

Today, within easy reach of New Zealand's growing cities, the spiritual descendants of the pioneers can still be found. They may call themselves musterers, fishermen, shepherds, prospectors, deer cullers, fire watchers, forestry workers or lighthouse keepers; but their true title, that of their earliest Polynesian forerunners, is tangata whenua - men of the land. ${ }^{78}$

Obviously, something could be said about the claims to indigeneity made in these texts. Similarly, being male appears to be a requirement of the New Zealander. What I want to highlight is the contrast between the man of the land who is the ostensible subject of these books, and the cosmopolitan, internationally-situated form of the book as object. Here, just as there was between the hell of war and the clean, green, and restorative idyll, a palpable tension played out between consumer-driven modernity and its anti-modern New Zealand counterpart. But, as Sharon Wall pointed out in her study of Canadian holiday camps, it was not a contrast that seems to have given pause for thought to many. ${ }^{79}$ In any case, Shadbolt had compiled another list:

\footnotetext{
77 Bigwood and Baxter, New Zealand in Colour, introduction.

78 Brian Brake and Maurice Shadbolt, New Zealand: Gift of the Sea (Christchurch: Whitcombe and Tombs, I963), 62.

79 Sharon Wall, The Nurture of Nature Childhood, Antimodernism, and Ontario Summer Camps, 1920-55, Nature, History, Society (Vancouver: UBC Press, 2009), esp 25I-257.
}

Pakeha anti-moderns: spread from Gift of the Sea showing musterers, with Baxter's poem 'High Country Weather'. 


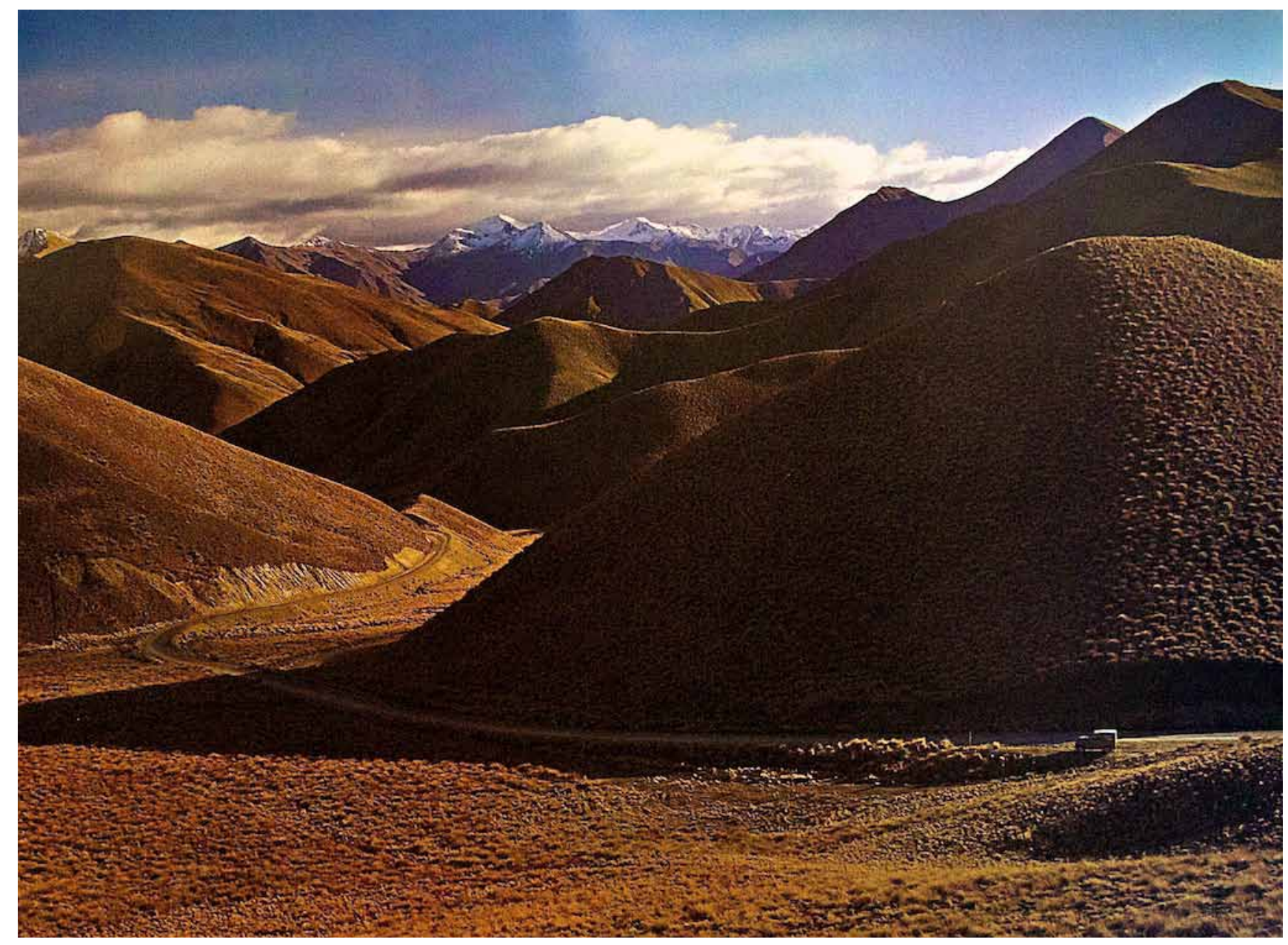

New Zealand in Colour, plate 42: In the Lindis Pass which links Canterbury and Otago. View looking westwards.

Ours is a nation of yachtsmen and trampers, swimmers and mountain climbers, fishermen and hunters, beachcombers and skiers. Between the salt spray of a wandering coast the the rugged peaks above the snowline, our national life has grown. ${ }^{80}$

The idealising of the anti-modern (and, as Wall notes, its limitations as a form of escape) stood out when Baxter used his own lines to accompany a photograph of the Lindis Pass in Central Otago:

Upon the upland road

Ride easy, stranger.

For readers from London to San Francisco, Shadbolt's lists could have been replaced by a single, internationally understood word: cowboy. ${ }^{81}$

80 Brake and Shadbolt, New Zealand, 66.

8I EJ Hobsbawm, 'The American Cowboy: An International Myth?’ Fractured Times: Culture and Society in the Twentieth Century (London: Little, Brown, 2013), 272-289. 


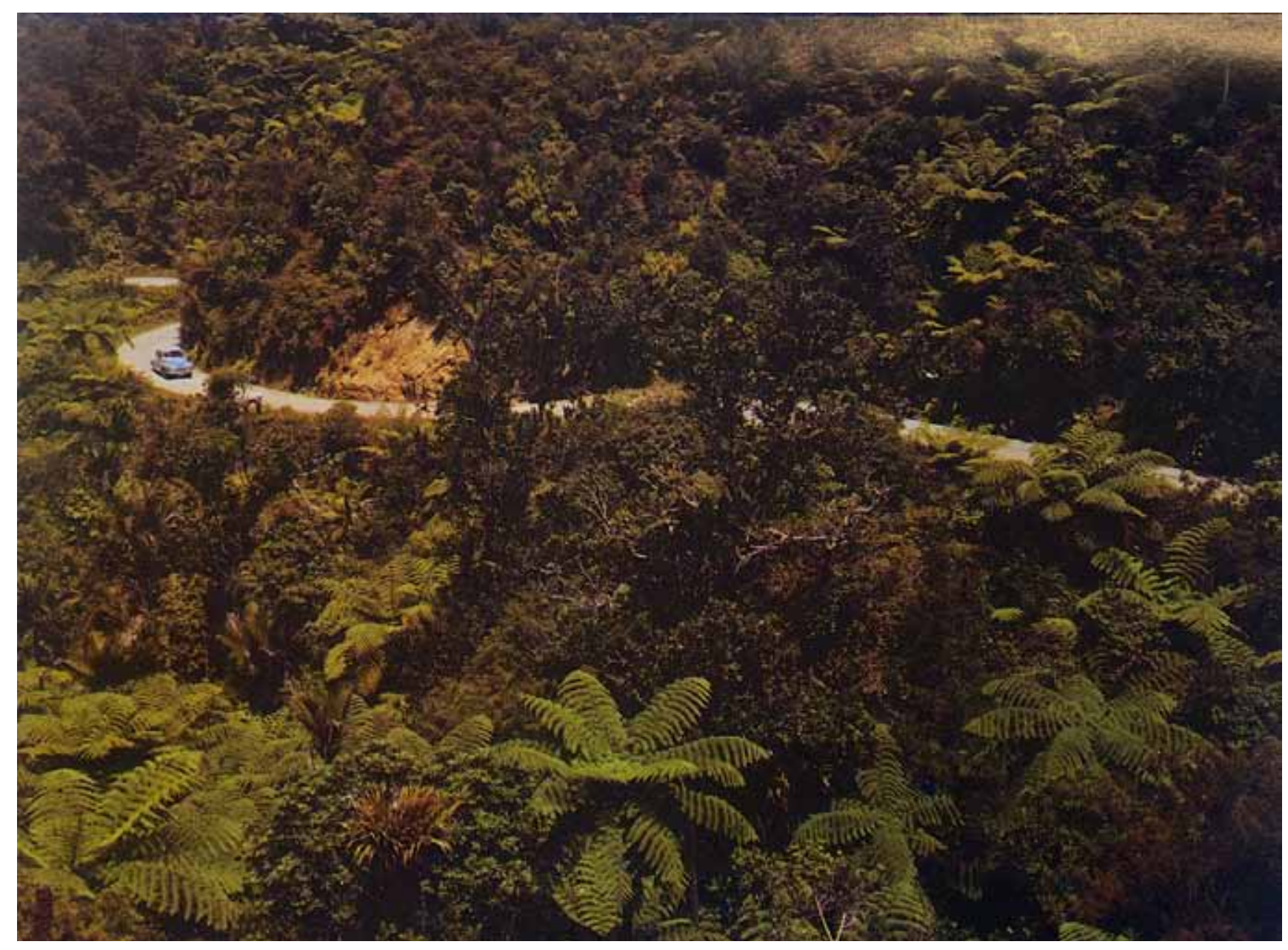

'The bush-lined road between Whitianga

\section{Like other folk}

Writing as Whim Wham in April 1967, Allen Curnow defined "image": and Kuaotunu, on the Coromandel Peninsula'. New Zealand in Colour, It's the Way we imagine OTHERS see Us Volume Two, plate 6 .

The Way we think we're thought of. ${ }^{82}$

It is hardly original to point out that Pakeha have long ruminated on the way the rest of the world thinks of them. Leaving aside, initially, the implied anxiety, the New Zealand pictorials offer an expansive way to interpret Curnow's lines based on the idea that consumption (which includes reading, but also looking, thumbing pages, buying, gifting, and owning) can be understood as a shared activity. What Curnow left unsaid was a powerful sense that 'others' were actually not all that different from 'us' - indeed, the anxiety was contained in the fear of unrecognition. The point of recognition, on the other hand, was to be acknowledged as modern. This unfolded in the following way. In New Zealand in Colour Volume Two, John Pascoe told a story:

82 Curnow, Whim Wham's New Zealand, I83. 
During the I940s the local cream truck driver used to plant flowers along the sides of the road on this hill - at least one a day, as he said, and as his was a seven-daya-week job during the summer, he planted many flowers. . . But since it became a main highway the Ministry of Works have widened and straightened the road, with the result that the flowers have either been covered over or bulldozed out. ${ }^{83}$

The pictorial places were made beautiful, in part, through the hand of man, in another manifestation of gift-giving. And once again the demands of modernity (exporting milk, and hastening travel and communication) were balanced against anti-modern sentiment.

Describing the home garden, Helen M Leach writes that it offered the New Zealand working man a congenial counterpoint to the rigidities of working life. But, Leach continues: 'Ethnographers have found the same overriding principles of social organisation and interaction to be reflected in the constructed landscapes of the communities they study, from house to tribal territory. ${ }^{34}$ From the home garden, then, it is a short step to Ebenezer Howard's social utopia of the garden city. ${ }^{85}$ The benefits believed to flow from a passion for gardening need not be confined to the suburbs, but might just as well be present throughout the 'tribal territory' of the highly suburbanised Pakeha. Nadia Gush, in an account of the Christchurch Beautifying Association, calls it 'urban planning styled to symbolize national culture'. Gush outlines changes in the front garden during the interwar period, operating in parallel with greater informality inside the house, which emphasised beautification as a civic duty in the form of the fenceless front garden. ${ }^{86}$ Leach argues for a complex shifting of the public-private divisions in both home and garden after the Second World War, and in particular that both inside and outside, 'the various recreational spaces can be interpreted as private family areas to which visitors could be invited'. ${ }^{87}$ This was the context in which readers in 1956 were meant to understand John Hardingham's observation that:

Like any other folk, New Zealanders are not blind to the commercial value of a lovely land, but they are apt to look on their country as a man looks on his garden - as a place for his own enjoyment and one which he is proud to share with his guests. $^{88}$

The ambivalence towards commodified relationships evident here was also present in the attitude to tourism described in the last chapter and in the use of the gift as a prophylactic against self-indulgence. And when Hardingham (and Pascoe) hint

83 Bigwood and Pascoe, New Zealand in Colour: Volume Two, pl 6.

84 Helen M Leach, 'The European House and Garden in New Zealand', At Home in New Zealand, 73,88 .

85 Adrian Franklin, City Life (Los Angeles: Sage, 2010), 63-7I.

86 Nadia Gush, 'Cultural Fields of the Canterbury Plains: Women and Cultural Citizenship in Canterbury c 1890-1940’ (PhD Thesis, Victoria University of Wellington, 2007), ch 7, esp I68, I72-I73.

87 Leach, in At Home in New Zealand, 86-87.

88 Hardingham, New Zealand Holiday I (1956), 8. 
that the growing reach of the market economy and postwar modernisation are the price of a sustaining membership of modernity, we should pause to ask just who Hardingham's 'any other folk' were. That they were not blind to commercial value brings to mind those at home amongst Rybczynski's morally unblemished "Free World" modernism.

The 'Kiwi', as Maurice Shadbolt pointed out, was also free: he possessed 'a physical freedom unmatched in the world. Chief ingredients of this physical freedom are bush and mountain, sand and sea. ${ }^{89}$ Baxter put it like this: 'When the pohutukawa blossoms flare out like gunfire, it is the sign for city dwellers to pour this way in cars, with food and stoves and sun-tan lotion, to pitch their tents and park their caravans on the shore below the Maori farms'. ${ }^{\circ}$ This was urban mythmaking in the style of the gifts of free land on the frontier. The ability to roam at will in the New Zealand garden was increasingly circumscribed and tents and caravans were more likely to be found in authorised locations. Pascoe, for example, noticed how Queenstown's 'motorcamps bulge at the fences'. As noted earlier, permanent holiday accommodation was shifting from makeshift communities of baches, cribs, and huts in favour of suburban resort developments. ${ }^{91}$ Sections in future Prime Minister Keith Holyoake's Kinloch subdivision beside Lake Taupo first went on sale in 1959. Barry Gustafson lists the pleasures the Prime Minister found there, including digging postholes, pushing through thick manuka scrub, and - "'What ho, lads"' - driving his powerboat too fast and close to anglers on the lakeshore.92 On his deathbed, Holyoake recalled Kinloch as his proudest achievement, yet Paul Hamer has characterised Holyoake's dealings there, while Prime Minister, relating to road construction, use of government resources, and subsequent purchase of Maori land as 'at least at the edge of impropriety'. Noting the incongruity, Hamer does not speculate on the cause. ${ }^{93}$ But even as they reveal Pakeha New Zealanders bumping over an unformed road of racial awareness, Baxter's caravans and Holyoake's re-enactment of the frontier share a longing for authentic experience and nostalgia for simpler times, albeit together with no small enthusiasm for the benefits of modernisation, that is typically urban in character.

When Holyoake made his Kinloch purchase in 1956, few Maori were participating in the ritual imaginative sharing of sun-tan lotion on the beach, and although their great migration to the cities was under way, it did not extend to embracing

89 Brake and Shadbolt, New Zealand, 65. 90 Bigwood and Baxter, New Zealand in Colour, pl 2I. 9I Bigwood and Pascoe, New Zealand in Colour: Volume Two, pl 44. For more on baches and cribs as an urban phenomenon, see Denis Hardy and Colin Ward, Arcadia for All (London: Mansell, I984), which explores the twentieth century history of makeshift holiday homes on the coasts of England.

92 Barry Gustafson, Kiwi Keith: A Biography of Keith Holyoake (Auckland: Auckland University Press, 2007), 8I-88.

93 Gustafson, Kiwi Keith; Paul Hamer, 'Kiwi Keith and Kinloch: A Closer Look at Holyoake's "Proudest Achievement", NZJH 44:2 (2010), I67, I69. 
the middle-class holiday. ${ }^{94}$ The relative absence of Maori from the pictorial books is best explained by, first, this lack of urbanisation, and secondly by the Pakeha preoccupation with Hardingham's 'other folk'. When Pakeha sought 'full integration of the Maori people into the main stream of New Zealand life', as proposed by the 196I Hunn report, this meant what 'The Maori Today', a I960 production of the National Film Unit, called 'the shift to modern living'. ${ }^{95}$ The film warned that 'learning to live like townsfolk is not easy' - an observation this study has suggested also applied to Pakeha.

The question arises, however, of just how distinct the New Zealand main stream was from 'any other folk' who lived in suburbs and tended gardens in Britain, Australia, South Africa, or North America? Not so different, as it happened, that the garden nation could not be shared as a scenic gift to the world - as 'the way we think we're thought of' or, as Shadbolt and Brake had it, a gift of the sea. The earlier discussion about the reach and functions of the gift book is clearly important to such a conception, but direct international publishing arrangements also provide support. After its initial local success in 196I, editions of New Zealand in Colour were published during the following two years in Australia by Lansdowne Press, Melbourne, in South Africa by Howard B Timmins, Cape Town, in London by Thames and Hudson, and in the United States by Wellington Books, Massachusetts. ${ }^{96}$ Of the initial print run for Gift of the Sea, 1500 copies were sent directly to Whitcombe \& Tombs' new shop in New Zealand House, London, and in 1964 a 'special edition' was prepared for the East-West Center Press at the University of Hawaii in Honolulu. ${ }^{97}$

It is nothing new to observe that Pakeha were preoccupied by the nature and extent of their participation in 'modern living'. In I96I, as he was describing New Zealand's relationship with Britain as 'provincial', Keith Sinclair noted the perceptiveness of another Whim Wham couplet:

In our Arts and our Letters they give us the Norm,

Those Overseas Standards to which we conform. ${ }^{98}$

As we have seen, although overseas standards proved to be anything but static, they continued to provide the primary authority for modern living. But tellingly,

94 Brian Easton, 'The Maori Urban Migration', www.eastonbh.ac.nz/20I2/ 08/the-maori-urbanmigration, accessed 20 August 2013. The general trend of Maori urbanisation, by which the proportion of Maori in urban areas increased from roughly a third in 1956 to three-quarters by I976, is shown at www.teara.govt.nz/en/graph/357I/ maori-urbanisation-I926-86.

95 'The Hunn Report,' Te Ao Hou 34 (March 196I), 6r; National Film Unit, 'The Maori Today', 1960, short film, www.nzonscreen.com/title/the-maori-today-1960.

96 Kenneth Bigwood and James K Baxter, New Zealand in Colour (Belmont, Mass: Wellington Books, 1962); Kenneth Bigwood and James K Baxter, New Zealand in Colour (London: Thames and Hudson, 1963).

97 Whitcombe \& Tombs Publications Register, Australia and New Zealand, I940s-1970s, Whitcoulls Archive no 2, 20II/25, vol 24, AwMML.

98 Keith Sinclair, 'Life in the Provinces', Distance Looks Our Way: The Effects of Remoteness on New Zealand (Hamilton: Paul's Book Arcade, I96I), 40. 
Sinclair thought that 'Overseasia' was 'one of our endemic diseases'. ${ }^{99}$ Writing about the development of consumer culture in the United States, the historian Jackson Lears points to 'the rise of a new gospel of therapeutic release', tracing a shift from nineteenth-century confidence men and quacks peddling patent medicines to a professional-managerial class selling sentimental domestic utopias. ${ }^{100}$ When in 1967 Baxter suggested that post-war poetry showed a 'change from a prophetic to a therapeutic view of art', it may have demonstrated how fully he had accepted the terms of the commodified society, but he had already mapped out a populist domestic utopia in New Zealand in Colour. ${ }^{\text {Ior }}$ Perhaps Sinclair's diagnosis might best be interpreted along with, for example, Holcroft's antimodern inflections or C $\mathrm{K}$ Stead's view that Pakeha saw the city as a place 'from which escape is made', as a deliberate point of difference with the main stream. ${ }^{102}$ Baxter's biographer described how the poet, when driving his car, 'seemed to dread the prospect of a mechanical breakdown in the same way that anyone else might dread a physical injury'. ${ }^{103}$ The colour books in contrast, showed a society outwardly at ease with the contradictions of modernity. As Hugh Hanning had put the matter in New Zealand Holiday, there was no place for the 'modern epidemic of escapism'. 'The New Zealander,' he confidently asserted, 'emancipated alike from monotony and drudgery, has really nothing to escape from.' 104

99 Ibid.

Ioo TJ Jackson Lears, Fables of Abundance: A Cultural History of Advertising in America (New York:

Basic Books, 1994), chs 7-8.

IOI James K Baxter, Aspects of Poetry in New Zealand (Christchurch: Caxton, 1967), 25.

I02 Monte Holcroft, Carapace: The Motor Car in New Zealand: A Roadside View (Dunedin: John

McIndoe, 1979); C K Stead, "“For the Hulk of the World Between”: New Zealand Writing,'

Distance Looks Our Way, 8I.

I03 McKay, The Life of James K Baxter, I8I.

I04 Hugh Hanning, 'Farmer, Fighter, Family Man', New Zealand Holiday 5 (I957), I2-I5. 


\section{Conclusion}

The book, writes Roger Chartier, 'has been one of the most powerful metaphors used for conceiving of the cosmos, nature, history, and the human body.' ${ }^{\text {'T }}$ This study has shown how, in the years following the Second World War, Pakeha came to use a particular form of the book for conceiving of New Zealand in such a way as to guarantee their place amidst rapidly changing conditions of modernity. The book, but specifically the photo essay, became a place through the interplay of cultural, social, and material influences. Images of New Zealand scenery had been collected into lavish books since the beginning of European settlement. In London, these first drawing-room books were created for the intimate enjoyment of the well off and co-existed alongside a more popular form of scenic display: the panorama. Pre-dating photography, their intent was to provide entertainment and an escape from urban life. By the end of the nineteenth century, locally-produced Imperial Albums of scenic photographs pictured New Zealand's place in the empire as a holiday resort for an 'imperially-engaged elite'. But locally, reproduction of images came to serve a greater role than simply entertainment and took on an essentially conservative function: institutionally, culturally, and morally, the best of British was being replicated in the colonial context. Then, in the twentieth century, a preoccupation with fidelity of reproduction permeated cultural nationalist thought. Adopting the language of the pioneer to create an intellectual home in the empty wilderness, the torch-bearers for high culture in New Zealand toiled to match the standards and achievements of the metropolitan centre. This aspect of their project usually went unacknowledged, however, in favour of an emphasis on discovering provincial differentiation.

In Britain, the publishing industry underwent rapid change during and after the Second World War. The success of German Jewish expatriate publishers and their different ideas of what constituted a book, new mass production and colour technologies, and a shift in the role of illustrations resulted in the production of many large-format pictorial books of photographs. The firm of Thames and Hudson was at the forefront of these developments and in New Zealand A H\&A W Reed closely followed its example, especially with its 1963 'Big Book', New Zealand. The colour pictorials challenged traditional ideas of what a book should be, but they also reveal a change in the cultural purpose of reproduction, away from ensuring fidelity to the original and instead asserting that New Zealand could be recognised (on the page) as an equal participant in modernity.

I Roger Chartier, The Order of Books (Cambridge: Polity Press, 1994), 90-9I. 
From its inception in 1955, ideas about photography came to be dominated by the New York Museum of Art's exhibition and book The Family of Man. Here, too, was a shift in cultural authority away from exclusively British models. The exhibition espoused a universal humanism - in part a reaction against the devastation of the war, partly the product of cold war anxiety. It was also an assertion that a world - or a nation that transcended politics - could exist though the medium of the photographic essay. Among the New Zealand pictorial books, Gift of the Sea explicitly adopted the style and form of The Family of Man. But the influence of these postwar ideals is visible in the attitude to life on display in all four colour books discussed here. Scenery remained the outward form: it continued to denote New Zealand's global connectedness. Yet the tourist who viewed the scene, and for whom all social relations were also financial transactions, had become a figure of suspicion. In part this was due to the long and fraught process of negotiating the shift from a producer to a consumer society; but did the more cosmopolitan, less British character of postwar tourism also have an influence? The colour pictorial books depicted a society in the midst of these changes, highlighting the challenges inherent in an increasingly service-based economy. Against the questionable morals of the tourist stood the family holiday. During their annual leave, and at weekends, men became full participants in the ideology of the family. Key to the holiday were the car and the camera: both were usually operated by men; both helped bring the family within the ambit of modernisation; both aided a more intimate and individualist possession of place. The New Zealand family of man became the world of a domesticated pioneer, in which the things that surrounded him, his mode of travel, and even the way that his leisure choices harked back to apparently simpler times, marked him out as unmistakably modern. His cultural colonisation was no longer imperial or provincial, but cosmopolitan.

The European origins of the colour pictorial were mediated through American values to produce the coffee table book. As with ambivalence towards tourism, the lavish production of the coffee table book risked unwarrantable self-indulgence in the purchaser. However, illustrated books had long been defined as gift books or presentation volumes. Lush colours amidst hardcover heft were acceptable as a reward for effort or service, recognition of family ties or obligations, or to forge connections with the wider world. The natural world had long been used to ameliorate suggestions of luxury, especially when it came to gift-giving, and this provided a further use for scenic imagery. As material objects, specifically as consumer goods, gifted coffee table books created, recognised, or reinforced emotional ties between people. Conceived as an attitude to life given the name New Zealand, they performed similar work with respect to the way Pakeha perceived their relationship to the place they lived in. Many Pakeha men who travelled overseas during the war found that their experiences prompted strong emotional responses of desire, affection, and even love for the place they knew as home. By the I960s, now trained and educated for secure and comfortably-paid employment, in a home of their own, and with a young family, they were able to enjoy this 'clean and green' place from 
the comfort of the living room. Even if the realities of limited holidays, expense, and family obligations meant that not all could experience first-hand the pleasures of the road, the beach and the caravan, the coffee table book ensured that the ideal remained, literally, at their fingertips.

The colour books were a publishing phenomenon in the I960s, but their impact faded during the following decade. In 1972, Kenneth and Jean Bigwood retooled for a projected New Zealand in Colour Volume 3 'safari', purchasing a new caravan, a new automatic-transmission Ford Falcon station wagon, and the latest colour processing and camera equipment. But the book never eventuated. On 20 October 1972, John Pascoe died. James K Baxter died two days later. Don Sinclair retired in 1975, and Ray Richards resigned the following year. In 1977, Reeds' tourist editor Dale Williams wrote to the Bigwoods: 'The New Zealand in Colour layout, admirable in its day, has now become rather tired and old-hat, and as a result is meeting with bookseller and buyer resistance.'2 A Mrs Weber of Christchurch wrote to Reeds in November 1976, distressed that a published photograph of Invercargill was so out of date: 'Scenery changes very little,' she thought, 'but townships and Citys [sic] do. ${ }^{3}$ Maurice Shadbolt was still around to revise his text for Gift of the Sea. It was given a new edition in 1973 and then resurrected, two years after Brake's death, for a sesquicentennial edition in 1990. New Zealand in Colour was reprinted for the last time in 1977, and the following year a decision was taken not to reprint Volume Two. Then in 1980, Reeds' shareholders sold an effective controlling interest in the company to Times Publishing Bhd, a Singaporean company. ${ }^{4}$ Whitcombe $\&$ Tombs (which became Whitcoulls in 1973, following a merger) came under full control of Brierley Investments Ltd in $1983 .{ }^{5}$ The era of the self-taught, self-made New Zealand man was closing.

Exploring the reasons for the colour pictorial's decline might offer interesting perspectives on the ways that New Zealand changed from the later i96os. The books' attempts to delineate the New Zealand character gave way to the claimed necessity of constructing an identity. What is interesting is not that distinctiveness was thought to be possible or even in existence. After all, that had always been understood. Rather, it is the claim that it would be found in identity, a profoundly internalising and individualising concept. The 'national' identity arrived at the high point of influence of the possibility - embodied in the coffee table book - that a series of photographic images might constitute something like a comprehensive totality. But the experience of universal identification (to recall Blake Stimson's phrase) that the colour pictorial provided began to look more like unreflectiveness. For mid-century Pakeha men, the universality of the colour pictorial was an

\footnotetext{
2 Dale Williams to Ken and Jean Bigwood, I9 August 1977, A H \& A W Reed author files and book proofs, 89-IIO-02, ATL.

3 Letter to Reeds, 30 November 1976, A H \& A W Reed author files and book proofs, 89-IIo-02,

ATL.

4 Gavin McLean, Whare Raupo: The Reed Books Story (Auckland: Reed, 2007), 205.

5 Noel Waite, Books for a Nation: The Whitcoulls Story (Auckland: Whitcoulls, 2008), I23.
} 
assertion of their own centrality as much as it was a demonstration of the power of objects to constitute a reality.

But the developing consumer society would not restrict these opportunities. In the early I970s, a new edition of Holcroft's New Zealand was much discussed by the men at Reeds, but it came to nothing. There were economic difficulties, as inflation in Japan meant printing there remained viable only with minimal revisions to existing plates. That seemed impossible. In February 1972, Clif Reed put it like this:

In Io years the position has changed materially. The Wahine \& Rangatira [Wellington-Lyttelton ferries] no longer run nightly, the EEC was not with us io years ago, there was little ferment among young people, loyalties to Queen \& Britain still ran high, there were apparently no problems, no Polynesian migration to NZ, TV wasn't much of a factor, the 6 o'clock swill had only just gone, $\&$ in fact we seemed to be a quiet, peace-loving, secure, middle-class, unimaginative, short back $\&$ sides, soberly dressed collection of conformists isolated from the world. ${ }^{6}$

To what extent did the transition to a consumer society, which 'replaced hard work with pleasure as the primary virtue', 7 also cause this shift from conformism to ferment? One possible answer might be found in the subsequent shift towards activism in the coffee table book itself. In March 1960 Ray Richards made the case to his fellow directors for publishing John Salmon's Heritage Destroyed, which warned of an impending 'crisis in scenery preservation' due to the 'calamitous effects' of the proposed Tongariro and Manapouri power schemes.

Because it is such a vital subject I would expect us not to lose money on the book, and it will do a great deal of good supporting Dr Salmon's excellent cause, and bring some small credit to our firm. ${ }^{8}$

In the United States, the Sierra Club was highlighting similar concerns. It did so, however, by initiating its Exhibit Format Series of coffee table books with a deliberately political goal. The first, entitled This Is the American Earth, by Ansel Adams and Nancy Newhall, advocated a 'stirring of love for the earth'. It was (like The Family of Man) preceded by an exhibition that was given a world tour by the United States Information Agency. ${ }^{9}$ No one at Reeds seems to have thought that a pictorial book might be put to such use. Neither did anyone else in New Zealand until the 1980s, when Craig Potton and Andy Dennis began to publish books of colour photographs that argued for environmental preservation. That decade has its own historical resonance: the men who came of age during the 196os threw open the

6 A W Reed to Ray Richards, 23 February 1972, A H\& A W Reed author files and book proofs, 89-IIO-02, ATL.

7 Chris Brickell, 'The Politics of Post-War Consumer Culture', NZJH 40:2 (2006), I44.

8 Ray Richards to AW Reed and Tom Kennedy, 9 March 1960, 'Executive Notes, I960', II7-II8, MSX-8IO3, ATL.

9 Ansel Adams and Sierra Club, This Is the American Earth, [Sierra Club Exhibit Format Series I] (San Francisco: Sierra Club, 1960); Finis Dunaway, Natural Visions: The Power of Images in American Environmental Reform (Chicago: University of Chicago Press, 2005), ch 5: 'Nature on the Coffee Table'. 
economy to the outside world because, as one of them remembered later, 'only two sorts of refrigerator were available - both made by the same manufacturer and to the same specifications' ${ }^{\text {ro }}$

A further question that this study circles, but which is beyond its scope to answer satisfactorily, is the nature of the influence of America. The Family of Man is, perhaps, just one example of evidence for a much deeper and more nuanced cultural relationship with New Zealand that already, in the early I960s, was extending beyond milk bars, honky tonk, and Hollywood movies. But determining influence in a globalising culture is not easy. Andrew Rosen points out that Britain also changed profoundly, but that it is hard to tell, often, what was American influence and what were simply effects of the new modernity. ${ }^{\mathrm{II}}$ As objects, consumer goods, and an attitude to life, this thesis argues that the colour pictorials fit within a narrative that places modernity, consumption, and leisure at its centre. The books created a community of users for whom New Zealand was reborn anti-modern, on the coffee table, but they remained part of the long and enduring story of the Pakeha relationship with scenery. In Katherine Mansfield's I9I3 short story Millie, a woman looks at the two pictures on the walls of her bedroom. Her wedding photograph, hung above a packing-case dressing table, has a staged background of ferns, a waterfall, and Mt Cook. The other is a coloured print entitled 'Garden Party at Windsor Castle'. 'I wonder if it really looked like that,' Millie wonders. Here are two great colonial preoccupations: making a home without falling irretrievably into isolation. New Zealanders' enthusiasm for Sir Peter Jackson's film adaptations of J R R Tolkien's The Lord of the Rings and The Hobbit, and the digitallyprocessed unreality of New Zealand-as-Middle-earth, show those concerns remain very much in evidence. And scenery, it sometimes appears, is still the only thing that can help us.

Io Don Brash, Fifth Annual Hayek Memorial Lecture, Institute of Economic Affairs, London, 4 June 1996, http://www.rbnz.govt.nz/speeches/o031201.html; Roger Douglas, Unfinished Business (Auckland: Random House, I993), 257.

II Andrew Rosen, The Transformation of British Life, 1950-2000: A Social History (Manchester:

Manchester University Press, 2003), ch 12. 



\section{Bibliography}

\section{Primary sources}

\section{Unpublished papers}

\section{Alexander Turnbull Library, Wellington}

A H Reed papers, correspondence, 75-053-4

AH\& A W Reed author files and book proofs, 89-IIo

AH\& A W Reed records, 79-I53

John Pascoe papers, correspondence, Ms-Papers-8179

Maurice Shadbolt papers, series II, notebooks and diaries, Ms-Group-I280

Monte Holcroft papers, correspondence, Ms-Papers-II86

Reed Publishing, further papers, Executive Notes, MSX-8I02- MSX-8IO8

\section{Auckland War Memorial Museum Library}

Whitcoulls Archive, I842-1992, MS 99/95

Whitcoulls Archive no 2, I878-2008, MS 2011/25

Hocken Library, University of Otago, Dunedin

Baxter family papers, Ms-II36

Baxter family photographs, Ms-0975

James K Baxter literary papers, Ms-0704

\section{Books}

Adams, Ansel, and Sierra Club. This Is the American Earth. [Sierra Club Exhibit Format Series I]. San Francisco: Sierra Club, 1960.

Allen, GF, and R Birt. The Second Country Life Picture Book of London. London: Country Life, 1956.

Ausubel, David Paul. The Fern and the Tiki: An American View of New Zealand National Character, Social Attitudes and Race Relations. Angus and Robertson, I960.

Baigent, Gary. The Unseen City: One Hundred and Twenty-three Photographs of Auckland. Auckland: Blackwood \& Janet Paul, 1967. 
Balfour, KW D. The Administrative Problems of Coping with Road Traffic Congestion in New Zealand: A Group Project. Wellington: School of Public Administration Victoria University of Wellington, 1964.

Baxter, James K. Aspects of Poetry in New Zealand. Christchurch: Caxton, 1967.

- Collected Poems. Auckland: Oxford University Press, 2003.

- Oil. Primary School Bulletin. Wellington: School Publications Branch, Department. of Education, 1957.

- Recent Trends in New Zealand Poetry. Christchurch: Caxton Press, 195I.

- The Fire and the Anvil: Notes on Modern Poetry. 3rd ed. Wellington: New Zealand University Press, I960.

Bigwood, Kenneth. Captured Images: The Photographic Legacy of Kenneth Bigwood. [Marlborough]: Millennium Art Gallery, 2004.

Bigwood, Kenneth, Jean Bigwood, and James K Baxter. New Zealand in Colour. Wellington: A H \& A W Reed, I96I.

—. New Zealand in Colour. London: Thames and Hudson, I96r.

—. New Zealand in Colour. Belmont, Mass: Wellington Books, 1962.

Bigwood, Kenneth, Jean Bigwood, and Harry Dansey. The New Zealand Maori in Colour. Wellington: AH \& A W Reed, 1963.

Bigwood, Kenneth, Jean Bigwood, and MH Holcroft. New Zealand. Wellington: AH \& AW Reed, 1963.

Bigwood, Kenneth, Jean Bigwood, and J D McDonald. The New Zealanders in Colour. Wellington: A H\& A W Reed, 1965.

Bigwood, Kenneth, Jean Bigwood, and John Pascoe. New Zealand in Colour: Volume Two. Wellington: AH\& A W Reed, 1962.

Brake, Brian, and Maurice Shadbolt. New Zealand: Gift of the Sea. Christchurch: Whitcombe and Tombs, 1963.

Brasch, Charles, ed. Landfall Country: Work from Landfall, 1947-61. Christchurch: Caxton Press, 1962.

Brees, S C. Pictorial Illustrations of New Zealand. London: J Williams, i849. http:// www.enzb.auckland.ac.nz/document?wid $=\mathrm{I} 452$.

Country Life Limited. Country Life Picture Book of the Lake District in Colour. Country Life Picture Book Series. London: Country Life, I96I.

Cowan, James. New Zealand, or, Ao-tea-roa (the Long Bright World): Its Wealth and Resources, Scenery, Travel-routes, Spas and Sport. Wellington: Department of Tourist and Health Resorts, 1908.

Cumberland, Kenneth. This Is New Zealand: New Zealand in Outline a Pictorial Description. Christchurch: Whitcombe and Tombs, 1960. 
Department of Internal Affairs, Centennial Branch. Making New Zealand: Pictorial Surveys of a Century. Wellington: Department of Internal Affairs, Centennial Branch, I939.

Duff, Oliver. New Zealand Now. 2nd ed. London: Allen \& Unwin, 1956.

Friedlander, Marti, and James McNeish. Larks in a Paradise: New Zealand Portraits. Auckland: Collins, 1974.

Goodman, Robert B. The Australians. Adelaide: Rigby, 1966.

Graham, Susan. This Land I Love. Wellington: Reed, 1962.

Griffith, RJ, and John Pascoe. New Zealand from the Air in Colour. Wellington: Reed, 1968.

Hall, D O W. Portrait of New Zealand. Wellington: A H \& A W Reed, 196I.

Holcroft, M H. Carapace: The Motor Car in New Zealand: A Roadside View. Dunedin: John McIndoe, I979.

—. Encircling Seas: An Essay. Christchurch: Caxton Press, 1946.

- The Deepening Stream: Cultural Influences in New Zealand. Christchurch:

The Caxton Press, 1940.

- The Eye of the Lizard: A Selection of Editorials from the New Zealand Listener, 1949-59. Wellington: A H \& A W Reed, 1960.

- A Sea of Words: Volume Two of an Autobiography. Whatamongo Bay: Cape Catley, 1986.

- The Waiting Hills. Wellington: Progressive Pub. Society, 1943.

Holme, Charles. The Art of the Book: A Review of Some Recent European and American Work in Typography, Page Decoration \& Binding. London, New York: 'The Studio', I9I4.

Hoppe, E. O. The Fifth Continent. Australian ed. London: Simpkin Marshall, I93I.

Jennett, Sean. The Making of Books. London: Faber, I95I.

Kerényi, Károly, Rudolf Hoegler, and Daphne Woodward. Greece in Colour. London: Thames \& Hudson, 1957.

Marsh, Ngaio. New Zealand. Britain in Pictures. London: William Collins, 1942.

Marx, Leo. The Machine in the Garden; Technology and the Pastoral Ideal in America. New York: Oxford University Press, 1964.

McCormick, E H. The Inland Eye: A Sketch in Visual Autobiography. Auckland: Auckland Gallery Associates, 1959.

Miller, Frederick. Golden Days of Lake County. Christchurch: Whitcombe and Tombs, I96I.

Millin, Sarah Gertrude Liebson. South Africa. Britain in Pictures. London: William Collins, I94I. 
Mountevans, Edward. British Polar Explorers. Britain in Pictures. London: William Collins, 1943.

National Parks Authority. National Parks of New Zealand. Wellington: Government Printer, 1965.

New Zealand Scenery Publishing Co. The Imperial Album of New Zealand Scenery. Wellington: New Zealand Scenery Publishing, I899.

Norris, H C M. Armed Settlers: The Story of the Founding of Hamilton, New Zealand, 1864-1874. Hamilton: Paul's Book Arcade, 1963.

Packard, Vance Oakley. The Status Seekers: An Exploration of Class Behavior in America and the Hidden Barriers That Affect You, Your Community, Your Future. New York: D McKay Co, 1959.

Pascoe, John Dobree. The Haast Is in South Westland. Wellington: Reed, 1966.

. The Mountains, the Bush and the Sea. Christchurch: Whitcombe \& Tombs, I95I.

Plischke, Ernst A. Design and Living. Wellington: Department of Internal Affairs, I947.

Potter, David Morris. People of Plenty: Economic Abundance and the American Character. Chicago: University of Chicago Press, 1954.

Radcliffe, F G. Beauty Spots in 'God's Own Country': Gems of New Zealand Scenery. Auckland: Frank Duncan \& Co, 1920.

Reed, A W. Books Are My Business: The Life of a Publisher. Reading: Educational Explorers, 1966.

- The House of Reed, 1957-1967. Wellington: A H \& A W Reed, 1968.

Reed, Alfred Hamish. From North Cape to Bluff: On Foot at Eighty-Five. Wellington: AH\& A W Reed, I96I.

Richards, JH. New Zealand Holiday Horizons: Selected from New Zealand Holiday. Wellington: A H \& AW Reed, 1958.

Scott, Dick. Inheritors of a Dream: A Pictorial History of New Zealand. Auckland: R Riddell, 1962.

Shadbolt, Maurice. From the Edge of the Sky: A Memoir. Auckland: David Ling, 1999.

—. The New Zealanders: A Sequence of Stories. [Christchurch]: Whitcombe and Tombs, 1959 .

Shaw, Bernard. What I Said in N.Z.: The Newspaper Utterances of Mr. George Bernard Shaw in New Zealand, March 15th to April 15th, 1934. Wellington: Commercial Print. and Pub, I934.

Sinclair, DW. 19 Battalion and Armoured Regiment. Official History of New Zealand in the Second World War, 1939-I945. Wellington: War History Branch, Department of Inernal Affairs, 1954. 
Sinclair, Keith, ed. Distance Looks Our Way: The Effects of Remoteness on New Zealand. Hamilton: Paul's Book Arcade for the University of Auckland, I96I.

Sinclair, Keith. A History of New Zealand. London: Penguin Books, 1959.

Smyth, Bernard W. The Role of Culture in Leisure Time in New Zealand. Studies and Documents on Cultural Policies. Paris: Unesco, I973.

Steichen, Edward. The Family of Man. New York: Museum of Modern Art, 1955.

Stone, Desmond, ed. Verdict on New Zealand. Wellington: Reed, I959.

Stowe, Harriet Beecher. 'Christmas', in National Era, 26 December I850. www. readbookonline.net/readOnLine/42658/.

Sutch, W B. Wellington: A Sick City. Wellington: Sweet and Maxwell, 1965.

Westra, Ans. Maori. Wellington: Reed, 1967.

Westra, Ans, James K Baxter, and Tim Shadbolt. Notes on the Country I Live In. Wellington: Alister Taylor, 1972.

White, Leo. White's Pictorial Reference of New Zealand: Representative Airviews of New Zealand Cities and Boroughs. Auckland: Whites Aviation, 1960.

\section{Film}

National Film Unit. 'The Maori Today'. Short film, 1960. http://www.nzonscreen. $\mathrm{com} /$ title/the-maori-today-I960.

_. 'Pictorial Parade no I45'. Short film, 1963. http://www.nzonscreen.com/ title/pictorial-parade-nor45-1963.

\section{Newspapers and periodicals}

Auckland Star

Dominion

Evening Post

Hawkes Bay Herald Tribune

Landfall

Life International

Marlborough Express

National Geographic Magazine

New Zealand Alpine Journal

New Zealand Camera

New Zealand Herald

New Zealand Holiday

New Zealand Motor World

New Zealand Women's Weekly 
Otago Daily Times

Southland Times

Taranaki Herald

$\mathrm{Te} \mathrm{Ao} \mathrm{Hou}$

The UNESCO Courier

\section{Official publications}

New Zealand Official Year-book

\section{Secondary sources}

\section{Books}

Alsop, Peter. Selling the Dream: The Art of Early New Zealand Tourism. Nelson: Craig Potton Publishing, 2012.

Altick, Richard. The English Common Reader; a Social History of the Mass Reading Public, 1800-1900. Chicago: University of Chicago Press, I957.

. The Shows of London. Cambridge, Mass: Belknap Press, 1978.

Anderson, Benedict. Imagined Communities: Reflections on the Origin and Spread of Nationalism. Rev. ed. London: Verso, 2006.

Anderson, Patricia. The Printed Image and the Transformation of Popular Culture, 1790-1860. Oxford: Clarendon Press, I99I.

Art Since 1900: Modernism, Antimodernism, Postmodernism. 2nd ed. London: Thames \& Hudson, 20II.

Auckland City Art Gallery, and Newstalk IzB I950s Show. New Zealand Home \& Building: The Newstalk 1ZB 1950s Show, Auckland City Art Gallery. Auckland: Robin Beckett, 1992.

Ballantyne, Tony. Webs of Empire: Locating New Zealand's Colonial Past. Wellington: Bridget Williams Books, 2012.

Ballon, Hilary, and Kenneth T Jackson. Robert Moses and the Modern City: The Transformation of New York. New York: WW Norton, 2007

Barnes, Felicity. New Zealand's London: A Colony and Its Metropolis. Auckland: Auckland University Press, 2012.

Barthes, Roland. Mythologies. London: Jonathan Cape, 1972.

Bayly, Janet. Witness to Change: Life in New Zealand: John Pascoe, Les Cleveland, Ans Westra: Photographs, 1940-1965. Wellington: PhotoForum, 1985.

Belich, James. Paradise Reforged: A History of the New Zealanders from the 1880s to the Year 2000. Auckland: Allen Lane; Penguin, 200I.

Bell, Leonard. Marti Friedlander. Auckland: Auckland University Press, 2009. 
Berman, Marshall. All That Is Solid Melts into Air: The Experience of Modernity. New York: Simon and Schuster, 1982.

Bohan, Edmund. The House of Reed 1907-1983: Great Days in New Zealand Publishing. Christchurch: Canterbury University Press, 2005.

Calder, Alex. The Settler's Plot: How Stories Take Place in New Zealand. Auckland: Auckland University Press, 20Ir.

Chartier, Roger. On the Edge of the Cliff: History, Language, and Practices. Baltimore: Johns Hopkins University Press, 1997.

- The Order of Books: Readers, Authors and Libraries in Europe Between the Fourteenth and Eighteenth Centuries. Cambridge: Polity, 1994.

Clark, Kenneth. Moments of Vision: \& Other Essays. New York: Harper \& Row, I98I.

Clarke, Alison. Holiday Seasons: Christmas, New Year and Easter in Nineteenth-century New Zealand. Auckland: Auckland University Press, 2007.

Cohen, Deborah. Household Gods: The British and Their Possessions. New Haven: Yale University Press, 2006.

Colligan, Mimi. Canvas Documentaries: Panoramic Entertainments in Nineteenthcentury Australia and New Zealand. Melbourne: Melbourne University Press, 2002.

Connolly, Joseph. Faber and Faber: Eighty Years of Book Cover Design. London: Faber, 2009.

Cronon, William. Uncommon Ground: Rethinking the Human Place in Nature. New York: W W Norton, 1996.

Curnow, Allen. Whim Wham's New Zealand: The Best of Whim Wham, 1937-1988. Auckland: Vintage, 2005.

Curran, James, and Stuart Ward. The Unknown Nation: Australia After Empire. Melbourne: Melbourne University Publishing, 2 oIo.

Curtis, Verna Posever, ed. Photographic Memory: The Album in the Age of Photography. Aperture/Library of Congress, 20II.

Davison, Graeme, and Sheryl Yelland. Car Wars: How the Car Won Our Hearts and Conquered Our Cities. Sydney: Allen \& Unwin, 2004.

Debord, Guy. The Society of the Spectacle. New York: Zone Books, 1994.

Diski, Jenny. The Sixties. London: Profile, 2009.

Douglas, Roger. Unfinished Business. Auckland: Random House, 1993.

Dunaway, Finis. Natural Visions: The Power of Images in American Environmental Reform. Chicago: University of Chicago Press, 2005.

Eggleton, David. Into the Light: A History of New Zealand Photography. Nelson: Craig Potton, 2006. 
Felmingham, Michael. The Illustrated Gift Book, 1880-1930: With a Checklist of 2500 Titles. Aldershot: Scolar Press, 1988.

Forster, EM. Howard's End. London: David Campbell, I99I.

Franklin, Adrian. City Life. Los Angeles: Sage, 2010.

- Retro: a Guide to the Mid-2oth Century Design Revival. Sydney: University of New South Wales Press, 20Ir.

Freedman, Carl Howard. The Incomplete Projects: Marxism, Modernity, and the Politics of Culture. Middletown, Conn: Wesleyan University Press, 2002.

Gernsheim, Helmut. L.J.M. Daguerre; the History of the Diorama and the Daguerreotype. New York: Dover Publications, 1968.

Giddens, Anthony. Modernity and Self-identity. Cambridge: Polity, I99I.

Gill, Eric. An Essay on Typography. David R. Godine Publisher, 1993.

Glaister, Geoffrey Ashall. Encyclopedia of the Book. 2nd ed. New Castle, Del: Oak Knoll Press, 1996.

Godelier, Maurice. The Enigma of the Gift. Chicago: University of Chicago Press, I999.

Gustafson, Barry. Kiwi Keith: A Biography of Keith Holyoake. Auckland: Auckland University Press, 2007.

Hamer, David. New Towns in the New World. New York: Columbia University Press, I990.

Hardy, Dennis. Arcadia for All: The Legacy of a Makeshift Landscape. London: Mansell, 1984.

Harris, Alexandra. Romantic Moderns: English Writers, Artists and the Imagination from Virginia Woolf to John Piper. London: Thames \& Hudson, 2010.

Harthan, John. The History of the Illustrated Book: The Western Tradition. London: Thames and Hudson, I98I.

Penny Griffith, Harvey, Douglas Ross, and Keith Maslen. Book and Print in New Zealand. Wellington: Victoria University Press, 1997.

Hawkes, Graham. On the Road: The Car in New Zealand. Wellington: GP Books, I990.

Hess, Scott. William Wordsworth and the Ecology of Authorship: The Roots of Environmentalism in Nineteenth-Century Culture. Charlottesville: University of Virginia Press, 2012.

Hilliard, Christopher. The Bookmen's Dominion: Cultural Life in New Zealand, 1920-1950. Auckland: Auckland University Press, 2006.

Hobsbawm, EJ. Fractured Times: Culture and Society in the Twentieth Century. London: Little, Brown, 20I3. 
Hyde, Lewis. The Gift: How the Creative Spirit Transforms the World. Edinburgh: Canongate, 2007.

Jameson, Fredric. A Singular Modernity: Essay on the Ontology of the Present. London: Verso, 2002.

Kammen, Michael. American Culture, American Tastes: Social Change and the 2oth Century. New York: Knopf, 1999.

Kaplan, Wendy, ed. California Design, 1930-1965: Living in a Modern Way. Los Angeles: Los Angeles County Museum of Art, $201 \mathrm{I}$.

Knight, Hardwicke. Photography in New Zealand: A Social and Technical History. Dunedin: John McIndoe, 197I.

Lears, TJ Jackson. Fables of Abundance: a Cultural History of Advertising in America. New York: Basic Books, 1994.

- No Place of Grace: Antimodernism and the Transformation of American Culture, 1880-1920. New York: Pantheon Books, I98I.

Liebersohn, Harry. The Return of the Gift: European History of a Global Idea. New York: Cambridge University Press, 20Ir.

Lippard, Lucy R. The Lure of the Local: Senses of Place in a Multicentered Society. New York: New Press, 1997.

Lloyd Jenkins, Douglas. At Home: A Century of New Zealand Design. Auckland: Godwit, 2004.

MacCannell, Dean. The Tourist: A New Theory of the Leisure Class. New York: Schocken Books, 1976.

Maclean, Chris. John Pascoe. Nelson: Craig Potton; Whitcombe Press, 2003.

- Stag Spooner Wild Man from the Bush: The Story of a New Zealand Hunter and Artist. Nelson: Craig Potton, 2012.

Mauss, Marcel. The Gift: The Form and Reason for Exchange in Archaic Societies. New York: W W Norton, 2000.

McClure, Margaret. The Wonder Country: Making New Zealand Tourism. Auckland: Auckland University Press, 2004.

McCrystal, John. 100 Years of Motoring in New Zealand. Auckland: Hodder Moa Beckett, 2003.

McKay, Frank. The Life of James K. Baxter. Auckland: Oxford University Press, 1990.

McKenzie, D F. Bibliography and the Sociology of Texts. London: British Library, I986.

McLean, Gavin. The Governors: New Zealand's Governors and Governors-General. Dunedin: Otago University Press, 2006.

. Whare Raupo: The Reed Books Story. Auckland: Reed, 2007. 
Mallarme, Stephane. Divagations: The 1897 Arrangement by the Author. Cambridge, Mass: Harvard University Press, 2007.

Miller, Daniel. Material Culture and Mass Consumption. Oxford: Basil Blackwell, 1987.

Milton, Kay. Loving Nature: Towards an Ecology of Emotion. New York: Routledge, 2002.

Moran, Joe. Queuing for Beginners: The Story of Daily Life from Breakfast to Bedtime. London: Profile, 2007.

Nissenbaum, Stephen. The Battle for Christmas. New York: Vintage Books, 1997.

O'Brien, Gregory. A Nest of Singing Birds: 100 Years of the New Zealand School Journal. Wellington: Learning Media, 2007.

Osborne, Peter. Travelling Light: Photography, Travel and Visual Culture. Manchester: Manchester University Press, 2000.

Park, Geoff. Theatre Country: Essays on Landscape \& Whenua. Wellington: Victoria University Press, 2006.

Parr, Joy. Domestic Goods: The Material, the Moral, and the Economic in the Postwar Years. Toronto: University of Toronto Press, 1999.

Parr, Martin. The Photobook: A History. 2 vols. London: Phaidon, 2004.

Pascoe, John, and Mahara Gallery. Songs of Innocence: Photographs of a New Zealand Childhood. Wellington: Pacific Press, 2005.

Payne, Alexander. The Coffee Table Coffee Table Book. London: Black Dog, 2003.

Pearson, David. Books as History: The Importance of Books Beyond Their Texts. London: British Library, 20II.

Pimlott, John Alfred Ralph. The Englishman's Christmas: A Social History. Hassocks: Harvester Press, 1978.

Pound, Francis. The Invention of New Zealand: Art \& National Identity, 1930-1970. Auckland: Auckland University Press, 2009.

Price, Leah. How to Do Things with Books in Victorian Britain. Princeton: Princeton University Press, 2012.

Proust, Marcel. Remembrance of Things Past. 3 vols. London: Chatto \& Windus, I98I.

Rosen, Andrew. The Transformation of British Life, 1950-2000: A Social History. Manchester: Manchester University Press, 2003.

Ross, Kirstie. Going Bush: New Zealanders and Nature in the Twentieth Century. Auckland: Auckland University Press, 2008.

Ross, Kristin. Fast Cars, Clean Bodies: Decolonization and the Reordering of French Culture. Cambridge, Mass: MIT Press, 1995. 
Runte, Alfred. National Parks: The American Experience. Lincoln: University of Nebraska Press, 1979.

Rybczynski, Witold. Home: A Short History of an Idea. New York: Viking, 1986.

Schrader, Ben. We Call It Home: A History of State Housing in New Zealand. Auckland: Reed, 2005.

Sinclair, Keith. Walter Nash. Auckland: Auckland University Press, 1976.

Slater, Michael, ed. Dickens' Journalism: The Amusements of the People and Other Papers: Reports, Essays and Reviews 1834-51. London: J M Dent, 1996.

Stearns, Peter N. American Cool: Constructing a Twentieth-century Emotional Style. The History of Emotions Series. New York: New York University Press, 1994.

Stimson, Blake. The Pivot of the World: Photography and Its Nation. Cambridge, Mass: MIT Press, 2006.

Sutter, Paul. Driven Wild: How the Fight Against Automobiles Launched the Modern Wilderness Movement. Weyerhaeuser Environmental Books. Seattle: University of Washington Press, 2002.

Thomas, Nicholas. Entangled Objects: Exchange, Material Culture, and Colonialism in the Pacific. Cambridge, Mass: Harvard University Press, I99I.

Thompson, Hamish. Coverup: The Art of the Book Cover in New Zealand. Auckland: Godwit, 2007.

Thomson, Jane. Origins of the 1952 National Parks Act. National Parks Series 1975/I. Wellington: Dept. of Lands and Survey, 1976.

Trade Union History Project. Workers' Holidays in New Zealand: A Brief History. Wellington: Trade Union History Project, 1997.

Victoria and Albert Museum. Modernism: Designing a New World, 1914-1939. London: V\&A Publications, 2006.

Waitangi Tribunal. Ko Aotearoa Tenei: a Report into Claims Concerning New Zealand Law and Policy Affecting Maori Culture and Identity. Waitangi Tribunal Report. Wellington: Legislation Direct, $201 \mathrm{.}$

Waite, Noel. Books for a Nation: The Whitcoulls Story. Auckland: Whitcoulls, 2008.

Waits, William Burnell. The Modern Christmas in America a Cultural History of Gift Giving. New York: New York University Press, 1993. http://muse.jhu.edu/ books/97808I4794869.

Wall, Sharon. The Nurture of Nature: Childhood, Antimodernism, and Ontario Summer Camps, 1920-55. Nature, History, Society. Vancouver: UBC Press, 2009.

Ward, Stuart. Australia and the British Embrace: The Demise of the Imperial Ideal. Melbourne: Melbourne University Press, 200I.

Watson, James. Links: A History of Transport and New Zealand Society. Wellington: Ministry of Transport, 1996. 
White, Richard. On Holidays: A History of Getting Away in Australia. Melbourne: Pluto Press Australia, 2005.

Wild, Antony. Coffee: A Dark History. New York: W.W. Norton, 2005.

Williams, Raymond. Culture and Materialism. London: Verso, 2010.

Willis, Anne-Marie. Illusions of Identity: The Art of Nation. Transvisual Studies. Sydney: Hale \& Iremonger, 1992.

- Picturing Australia: A History of Photography. Sydney: Angus \& Robertson, 1988.

Wright, Matthew. Cars Around New Zealand. [Auckland]: Whitcoulls, 2005.

\section{Articles in books}

Appadurai, Arjun. 'Introduction: Commodities and the Politics of Value'. The Social Life of Things Commodities in Cultural Perspective. Cambridge: Cambridge University Press, 1986, 3-63.

Brooking, Tom. 'So Different From the USA: Our Late Appreciation of Wilderness', Mick Abbott and Richard Reeve, eds. Wild Heart: The Possibility of Wilderness in Aotearoa New Zealand. Dunedin: Otago University Press, 20II, I23-I3I.

Conekin, Becky. "Here is the Modern World Itself”: The Festival of Britain's Representations of the Future'. Moments of Modernity: Reconstructing Britain, 1945-1964. London: Rivers Oram Press, 1999.

Daley, Caroline. 'Modernity, Consumption and Leisure'. Giselle Byrnes, ed. The New Oxford History of New Zealand. Melbourne: Oxford University Press, 2009, $423-445$.

Fox, Richard Wightman and TJ Jackson Lears. 'Introduction'. The Culture of Consumption: Critical Essays in American History, 1880-1980. New York: Pantheon Books, 1983, ix-xvii.

Gibbons Peter. 'Non-Fiction'. Terry Sturm, ed. The Oxford History of New Zealand Literature in English, 2nd edn. Auckland: Oxford University Press, 1998, 3I-II8.

Gidley, Mick. 'Emil Otto Hoppé, Autobiography, and Cultural Moments'. Patrizia Di Bello, Colette Wilson, and Shamoon Zamir, eds. The Photobook: From Talbot to Ruscha and Beyond. London: I B Tauris, 2012, 52-70.

Hall, Catherine, and Sonya Rose. 'Being at Home with the Empire'. Catherine Hall and Sonya Rose, eds. At Home with the Empire: Metropolitan Culture and the Imperial World. Cambridge: Cambridge University Press, 2006, I-3I.

Hipkins, Gavin. 'Dreamers that Struggle to Wake'. Handboek: Ans Westra Photographs. Wellington: Bwx, 2004, 63-72. 
Hinsley, Curtis. 'Strolling Through the Colonies'. Michael Steinberg, ed. Walter Benjamin and the Demands of History. Ithaca: Cornell University Press, 1996, II9-I4O.

Hunter, Fred. 'Matheson, Hilda (1888-1940)'. Oxford Dictionary of National Biography (Oxford University Press, 2004) online ed., May 20I2. http://www. oxforddnb.com/view/article/49198, accessed 28 April 2013.

Ireland, Peter. 'Looking at New Zealand, I960-1988'. Athol McCredie, ed. Brian Brake: Lens on the World. Wellington: Te Papa Press, 2010, 245-282.

Kirchhoff, Frederick. 'History Becomes Geography: Tracing William Morris's Later Thought'. Writing on the Image: Reading William Morris. Toronto: University of Toronto Press, 2007, I73-I82.

Labrum, Bronwyn. 'The Changing Meanings and Practices of Welfare, I840s-I99os'. Giselle Byrnes, ed. The New Oxford History of New Zealand. Melbourne: Oxford University Press, 2009, 389-422.

Leach, Helen M. 'The European House and Garden in New Zealand'. Barbara Brookes, ed. At Home in New Zealand: Houses, History, People. Wellington: Bridget Williams Books, 2000, 73-88.

Lears, TJ Jackson. 'From Salvation to Self-realization: Advertising and the Therapeutic Roots of the Consumer Culture, I880-1930'. Richard Fox and Jackson Lears, eds. The Culture of Consumption: Critical Essays in American History, 1880-1980. New York: Pantheon Books, 1983, I-38.

McDonald, Lawrence. 'From The Family of Man to the Family of "Ans"'. Handboek: Ans Westra Photographs. Wellington: в wx, 2004, 73-92.

McFarlane, Kyla. 'Sentences Forming Stories: Ans Westra's Maori and Edward Steichen's Family of Man'. Handboek: Ans Westra Photographs. Wellington: вw x, 2004, 5I-62.

Merriman, Peter. “'Beautified' Is a Vile Phrase”: The Politics and Aesthetics of Landscaping Roads in Pre- and Postwar Britain'. Christof Mauch and Thomas Zeller, eds. The World Beyond the Windshield: Roads and Landscapes in the United States and Europe. Athens, Ohio: Ohio University Press, 2008, I68-I86.

Montgomerie, Deborah. 'Sweethearts, Soldiers, Happy Families: Gender and the Second World War'. Deborah Montgomerie and Caroline Daley, eds. The Gendered Kiwi. Auckland: Auckland University Press, 1999, 163-190.

Nolan, Melanie. 'Constantly On the Move, But Going Nowhere?' The New Oxford History of New Zealand. Giselle Byrnes, ed. Melbourne: Oxford University Press, 2009, 357-387.

Rosenthal, Tom. 'Walter and Eva Neurath: Their Books Married Words with Pictures'. Richard Abel and William Gordon Graham, eds. Immigrant Publishers: The Impact of Expatriate Publishers in Britain and America in the 2oth Century. New Brunswick: Transaction Publishers, 2009, III-I22. 
Rubin, Joan. 'Between Culture and Consumption: The Mediations of the Middlebrow'. Richard Fox and Jackson Lears, eds. The Power of Culture: Critical Essays in American History. Chicago: University of Chicago Press, 1993, I63-194.

Schnapp, Jeffrey. 'The Romance of Caffeine and Aluminum'. Things. Chicago: University of Chicago Press, 2004, 304-329.

Shaw, Louise. 'A Woman's Place?' Barbara Brookes, ed. At Home in New Zealand: Houses, History, People. Wellington: Bridget Williams Books, 2000, I65-180.

Shep, Sydney. “"Touching the Mind of the Country": JC Beaglehole and the Design of the Centennial Publications'. Creating a National Spirit: Celebrating New Zealand's Centennial. Wellington: Victoria University Press, 2004, 193-206.

Skinner, Damian. 'Accidental Tourists: Ans Westra, Gregory Riethmaier and the National Publicity Studios in Rotorua, c 1963'. Anna Smith and Lydia Wevers, eds. On Display: New Essays in Cultural Studies. Wellington: Victoria University Press, 2004, 80-99.

Turner, John. 'The Roving Photojournalist'. Athol McCredie, ed. Brian Brake: Lens on the World. Wellington: Te Papa Press, 2010, 43-I68.

\section{Articles}

Armstrong, Nancy. 'The Pivot of the World: Photography and Its Nation'. Book review. Modernism/Modernity I4:2 (2007), 382-384.

Atkinson, Neill. "Call of the Beaches': Rail Travel and the Democratisation of Holidays in Interwar New Zealand'. Journal of Transport History 33:I (June 20I2), I-20.

Bagnall, A G, et al. 'SC Brees: artist and surveyor'. Turnbull Library Record I:4 new series (November 1968), 36-53.

Ballantyne, Tony. 'On Place, Space and Mobility in Nineteenth-Century New Zealand'. NZJH 45:I (April 20II), 50-70.

_. 'Thinking Local: Knowledge, Sociability and Community in Gore's Intellectual Life, I875-I9I4'. NZJH 44:2 (October 2010), I38-I56.

Brace, Catherine. 'Publishing and Publishers: Towards an Historical Geography of Countryside Writing, c 1930-I950'. Area 33:3 (September 200I), 287-296.

Brailsford, Ian. "Enlightened Buying”: From Consumer Service to the Consumers' Institute, I959-I964'. NZJH 4I:2 (2007), I23-I42.

Brickell, Chris. 'The Politics of Post-War Consumer Culture'. NZJH 40:2 (2006): I33-I55.

Brown, Bill. 'Thing Theory’. Critical Inquiry 28:I (Autumn, 200I), I-22.

Byrnes, Giselle, and Catharine Coleborne. 'Editorial Introduction: The Utility and Futility of 'the Nation' in Histories of Aotearoa New Zealand'. NZJH 45:I (April 20II), I-I4. 
Davis Jr, O L. 'Action as Part of Advocacy: Advancement of Progressive Education Practices by Professional Associations'. American Education History Journal 32:I (2005), I-9.

Dewald, Jonathan. 'Roger Chartier and the Fate of Cultural History'. French Historical Studies 2I:2 (Spring, 1998), 22I-240.

Elliott, JK. The Book: A History of the Bible, by Christopher de Hamel. Book review. Novum Testamentum 45:2 (April 2003), 198-200.

Gibbons, Peter. 'Cultural Colonization and National Identity' 36, no. I. NZJH (2002): 5-17.

—. 'The Far Side of the Search for Identity: Reconsidering New Zealand History'. NZJH 37, no. I (2003): 38-49.

Gibson, Stephanie. 'Display folk: Second World War posters at the Museum of New Zealand Te Papa Tongarewa'. Tuhinga i9 (2008), 7-27.

Gillis, John R. 'Island Sojourns'. Geographical Review 97:2 (April 2007), 274-287.

Graham, Jeanine, and Peter Gibbons. ‘Editorial Introduction'. NZJH 36:I (2002), 3-4.

Hamer, Paul. 'Kiwi Keith and Kinloch: A Closer Look at Holyoake's "Proudest Achievement”'. NZJH 44:2 (2010), I57-I73.

Hamilton, Fiona. 'Pioneering History: Negotiating Pakeha Collective Memory in the Late Nineteenth and Early Twentieth Centuries'. NZJH 36:I (2002), 66-8I.

Harris, Christopher. 'Slow Train Coming: The New Zealand State Changes its Mind about Auckland Transit, 1949-56'. Urban Policy and Research 23:I (2005), $37-55$.

Hilliard, Chris. 'Colonial Culture and the Province of Cultural History'. NZJH 36:I (2002), 82-97.

Jones, Ronald. ‘Blundell, Henry Percy Fabian'. From An Encyclopaedia of New Zealand, edited by A H McLintock, 1966. Te Ara - the Encyclopedia of New Zealand, updated 27 October 20Ir. http://www.teara.govt.nz/en/1966/ blundell-henry-percy-fabian.

Kelsey, Robin. 'Our Lady of Perpetual Help: Thoughts on Recent Photographic Scholarship'. Aperture, 210 (Spring 2013), 50-55.

Knott, John. "The "Conquering Car": Technology, Symbolism and the Motorisation of Australia before World War Ir'. Australian Historical Studies 3I:II4 (April 2000) I-26.

- 'Speed, Modernity and the Motor Car: The Making of the 1909 Motor Traffic Act in New South Wales'. Australian Historical Studies 26:103 (October I994), 22I-24I.

MacCannell, Dean. 'Staged Authenticity: Arrangements of Social Space in Tourist Settings'. American Journal of Sociology 79:3 (November 1973), 589-603. 
'Why it Never Really was About Authenticity'. Society 45:4 (2008), 334-337.

McLean, Gavin. 'Among the Reeds: Using the A H\& A W Reed Collections'. Turnbull Library Record 43 (2010-II), 32-39.

Mahy, Margaret. 'Truth and Desire'. Sport 7 (Winter 199I), I3. http://nzetc. victoria.ac.nz/tm/scholarly/tei-Bao7Spo-_N67539.html.

Mason, Andrew. 'Holcroft, Montague Harry'. From the Dictionary of New Zealand Biography. Te Ara - the Encyclopedia of New Zealand, updated 30 October 2012. http://www.teara.govt.nz/en/biographies/5h28/ holcroft-montague-harry.

New Zealand Food History Society. The Aristologist: An Antipodean Journal of Food History. Wellington: Kawhiti House, 20II.

O’Brien, Gregory. 'After Bathing at Baxter’s'. Sport II (Spring 1993), I22-I57.

Pickles, Katie. 'The Obvious and the Awkward: Postcolonialism and the British World’. NZJH 45:I (April 20II): 85-IOI.

Pollock, Jacob. 'Cultural Colonization and Textual Biculturalism: James Belich and Michael King's General Histories of New Zealand'. NZJH 4r:2 (2007), I80-I98.

Rennie, Paul. 'British Picture Books for Grown-ups from the r94os'. September 2005. http://www.rennart.co.uk/website.pdfs/books.pdf.

- 'Socialvision: Visual culture and social democracy in Britain during World War II'. Journal of War and Culture Studies I:3 (2008), 243-259.

Ringer, Mim 'Radcliffe, Frederick George'. From the Dictionary of New Zealand Biography. Te Ara - the Encyclopedia of New Zealand, updated 30 October 20I2. http://www.teara.govt.nz/en/biographies/3rI/radcliffe-frederick-george.

Rolfe, Mark. 'Faraway Fordism: The Americanization of Australia and New Zealand during the I950s and 1960s'. NZJH 33:I (1999), 65-9I.

Russell, James, 'Puffins on the Plate'. Eye 22:85 (2013), 62-7I.

Sato, Hiroaki. 'Remains of the Occupation Mentality'. Japan Times, November 29, 2004. http://www.japantimes.co.jp/opinion/2004/II/29/commentary/ remains-of-the-occupation-mentality.

Sekula, Alan. 'The Traffic in Photographs', Art Journal 4r:I (Spring 1981), 15-25.

Smith, Anthony. 'Rayner Unwin', Guardian, 27 November 2000. http://www. theguardian.com/news/2000/nov/27/guardianobituaries.books.

Smithies, James D. 'An Antimodern Manqué: Monte Holcroft and The Deepening Stream’. NZJH 40:2 (2006), I7I-193.

Stephens, Joy. 'Interview: Ray Richards' Lifelong Love Affair,' New Zealand Listener, 9 January 2013.

Turner, Fred. 'The Family of Man and the Politics of Attention in Cold War America'. Public Culture 24:I (2012), 55-84. 
Verry, Leslie. 'Blundell, Henry’. From the Dictionary of New Zealand Biography. Te Ara - the Encyclopedia of New Zealand, updated 30 October 20I2. http:// www.teara.govt.nz/en/biographies/2b29/blundell-henry.

White, Richard. 'The Australian Way of Life'. Historical Studies I8:73 (1979), 528-545.

\section{Theses}

Alessio, Dominic. 'Coloured Views: Images of the New Zealand City and Town, 1880-1930'. PhD Thesis, Victoria University of Wellington, 1992.

Barnes, Felicity. 'New Zealand's London: The Metropolis and New Zealand's Culture, I890-1940'. PhD Thesis, University of Auckland, 2008.

Bednarek, Antje. 'Put on the Margins?: The Mainstream Culture and the Alienated Writer in the Fifties'. MSocSci Thesis, Lincoln University, 2006.

Benjamin, Julie Maree. 'Transparencies: New Zealand from 1953 to 1974 through the Slide Photography of Gladys Cunningham'. PhD Thesis, University of Auckland, 2009.

Gush, Nadia Joanne. 'Cultural Fields of the Canterbury Plains: Women and Cultural Citizenship in Canterbury c. 1890-1940'. PhD Thesis, Victoria University of Wellington, 2007.

Hilliard, Chris. 'Island Stories: The Writing of New Zealand History, 1920-I940'. MA Thesis, University of Auckland, 1997.

Johnston, Rosslyn Joan. 'Colour Printing in the Uttermost Part of the Sea: A Study of the Colour Print Products, Printers, Technology and Markets in New Zealand, I830-1914'. PhD Thesis, Victoria University of Wellington, 2002.

Liebich, Susann. 'Connected Readers: Reading Practices and Communities Across the British Empire, c. I890-1930'. PhD Thesis, Victoria University of Wellington, 2012.

Mills, Anne-Maree. 'A Dictatorship of Taste: Cultural Nationalism and the Function of the Critic, 1947-I96I'. MA Thesis, University of Canterbury, 2009.

Schrader, Ben. 'Planning Happy Families: A History of the Naenae Idea'. MA Thesis, Victoria University of Wellington, 1993.

Smithies, James D. 'Imagining New Zealand: Literary Critique and Cultural Redefinition 1940-I983'. PhD Thesis, University of Canterbury, 2002.

Waite, Noel. 'Adventure and Art: Literature Publishing in Christchurch, 1934-95'. PhD Thesis, University of Canterbury, 1996.

Whitcher, Gary Frederick. "More Than America": Some New Zealand Responses to American Culture in the Mid-Twentieth Century'. PhD Thesis, University of Canterbury, 20II. 


\section{Unpublished papers}

Jolly, Martyn. 'Australiana Photobooks of the 1960s'. Unpublished conference paper. 'Contact', Art Association of Australia and New Zealand conference, 7-9 December 2011.

Ross, Kirstie. "We Bring Our Vans from Near and Far": Family Holidays in New Zealand after the Second World War'. Unpublished conference paper. 'Man Alone', Stout Research Centre, Victoria University of Wellington, I-2 September 2011.

\section{Web pages}

'I96I - key events'. New Zealand History Online, MCH, updated 20 December 20I2. http://www.nzhistory.net.nz/culture/the-1960s/196I-key-events.

Angles, Jeffrey. Interview with Takahashi Mutuo, June 9, 2005. http:// intersections.anu.edu.au/issueı//takahashi_interview.html.

Benjamin, Walter. 'The Work of Art in the Age of Mechanical Reproduction'. Transcribed by Andy Blunden, 1998. ucla School of Film and Television. http://www.marxists.org/reference/subject/philosophy/works/ge/benjamin. htm.

Brash, Don. Fifth Annual Hayek Memorial Lecture. Institute of Economic Affairs, London, 4 June 1996. http://www.rbnz.govt.nz/speeches/o03120I.html.

Cody, David. 'Morris and the Kelmscott Press'. The Victorian Web. http://www. victorianweb.org/authors/morris/kelmscott.html.

‘Coffee - Gregg’s’. Cerebos Gregg’s Ltd. www.greggs.co.nz/coffee.

Dauner, Maia. 'The Pivot of the World'. Book review. InVisible Culture. http://ivc.lib.rochester.edu/portfolio/ the-pivot-of-the-world-photography-and-its-nation.

Derby, Mark. 'Veterans' assistance - Economic rehabilitation'. Te Ara - the Encyclopedia of New Zealand, updated 9 November 2012. www.TeAra.govt. $\mathrm{nz} / \mathrm{en} /$ veterans-assistance.

Dravitzki, Vince, and Tiffany Lester. 'Some Interesting Old Transport Data And Where To Find It'. Opus International Consultants, Lower Hutt. http://www. opus.co.nz/frstweb/co2/Some interesting old transport data and where to find it.pdf.

Easton, Brian. 'The Maori Urban Migration'. www.eastonbh.ac.nz/2012/08/ the-maori-urban-migration.

Foto Freo 2010 Programme: The City of Fremantle Exhibition of Photography. http:// www.inmycommunity.com.au/_uploads/pDF/FotoFreo_20Io_Programme. pdf.

Phillips, Jock. 'Beach Culture'. Te Ara - the Encyclopedia of New Zealand, updated 9 November 20I2. http://www.teara.govt.nz/en/beach-culture. 
Meredith, Paul. 'Urban Maori - Urbanisation'. Te Ara - the Encyclopedia of New Zealand, updated I5 November 2012. http://www.TeAra.govt.nz/en/ graph/357I/maori-urbanisation-I926-86.

Museum of Modern Art. 'Internationally Circulating Exhibitions'. List of exhibitions shown outside USA, I952-2004. http://www.moma.org/docs/ learn/icelist.pdf.

Museum of New Zealand Te Papa Tongarewa. 'Topic: Art Photography Collection'. http: //collections.tepapa.govt.nz/theme.aspx?irn=358I.

'New Zealand'. E O Hoppé Estate Collection. http://www.eohoppe.com/ newzealand.html.

New Zealand Government. 'Budget 2013: \$2m for "New Zealand Story” project'. Press release, 20 May 20I3. http://www.scoop.co.nz/stories/pAI305/s00397/ budget-2013-2m-for-new-zealand-story-project.htm.

Rocky Mountain Online Archive. 'Kenneth and Jean Bigwood: An Inventory of Their Photographs at the Denver Museum of Nature \& Science'. http://rmoa. unm.edu/docviewer.php?docId=codmnhiabig7.xml.

Roman, Michael. 'The Sunny i6 Rule'. Boston West Photographic Society. http:// www.bwps.org/res/tips/sunny_ı6/.

'Southern Africa: A Portrait in Black and White Joy Horwood Cooke'. Actuphoto. http://actuphoto.com/13562-southern-africa-a-portrait-in-black-and-white-joyhorwood-cooke.html.

'Transcript: Michelle Obama’s Convention Speech'. NPR. 4 September 2012. www.npr.org/2012/09/04/160578836/ transcript-michelle-obamas-convention-speech.

'TSS Earnslaw, History'. http://www.tssearnslaw.co.nz/tss-earnslaw/History/.

'Wellington cafe culture'. New Zealand History Online, мсн, updated 20 December 20I2. www.nzhistory.net.nz/culture/ the-daily-grind-wellington-cafe-culture-1920-2000. 
